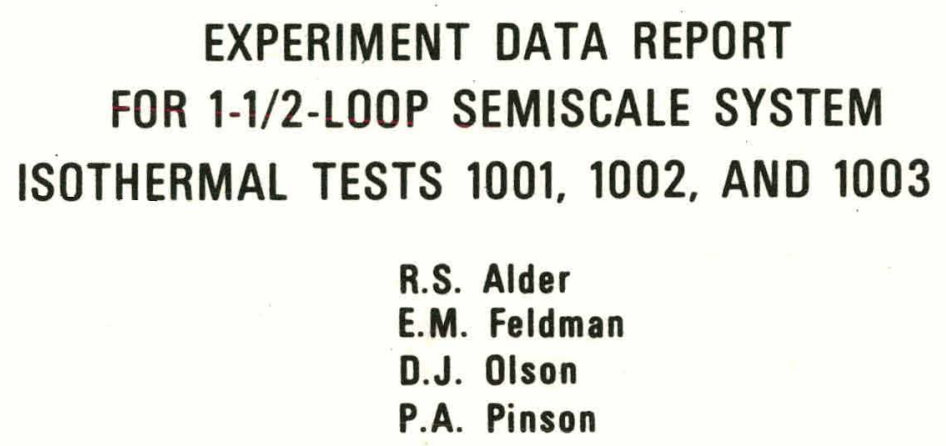

Aerojet nuclear Company

NATIONAL REACTOR TESTING STATION Idaho Falls, Idaho - 83401

DATE PUBLISHED-MAY 1974

\title{
U. S. ATOMIC ENERGY COMMISSION
}




\section{DISCLAIMER}

This report was prepared as an account of work sponsored by an agency of the United States Government. Neither the United States Government nor any agency Thereof, nor any of their employees, makes any warranty, express or implied, or assumes any legal liability or responsibility for the accuracy, completeness, or usefulness of any information, apparatus, product, or process disclosed, or represents that its use would not infringe privately owned rights. Reference herein to any specific commercial product, process, or service by trade name, trademark, manufacturer, or otherwise does not necessarily constitute or imply its endorsement, recommendation, or favoring by the United States Government or any agency thereof. The views and opinions of authors expressed herein do not necessarily state or reflect those of the United States Government or any agency thereof. 


\section{DISCLAIMER}

Portions of this document may be illegible in electronic image products. Images are produced from the best available original document. 


\section{DISCLAIMER}

This report was prepared as an account of work sponsored by an agency of the United States Government. Neither the United States Government nor any agency Thereof, nor any of their employees, makes any warranty, express or implied, or assumes any legal liability or responsibility for the accuracy, completeness, or usefulness of any information, apparatus, product, or process disclosed, or represents that its use would not infringe privately owned rights. Reference herein to any specific commercial product, process, or service by trade name, trademark, manufacturer, or otherwise does not necessarily constitute or imply its endorsement, recommendation, or favoring by the United States Government or any agency thereof. The views and opinions of authors expressed herein do not necessarily state or reflect those of the United States Government or any agency thereof. 


\section{DISCLAIMER}

Portions of this document may be illegible in electronic image products. Images are produced from the best available original document. 
Printed in the United States of America Available from

National Technical Information Service

U. S. Department of Commerce

5285 Port Royal Road

Springfield, Virginia 22151

Price: Printed Copy $\$ 5.45$; Microfiche $\$ 0.95$

\section{LEGAL NOTICE}

This report was prepared as an account of work sponsored by the United States Government. Neither the United States nor the United States Atomic Energy Commission, nor any of their employees, nor any of their contractors, subcontractors, or their employees, makes any warranty, express or implied, or assumes any legal liability or responsibility for the accuracy, completeness or usefulness of any information, apparatus, product or process dis-

closed, or represents that its use would not infringe privately owned rights. 
EXPERIMENT DATA REPORT FOR 1-1/2-LOOP SEMISCALE SYSTEM

ISOTHERMAL TESTS 1001, 1002, AND 1003

by

R. S. Alder

E. M. Feldman

D. J. Olson

P. A. Pinson

\section{AEROJET NUCLEAR COMPANY}

Date published - May 1974

\section{PREPARED FOR THE U. S. ATOMIC ENERGY COMMISSION \\ IDAHO OPERATIONS OFFICE \\ UNDER CONTRACT NO. AT(10-1)-1375}

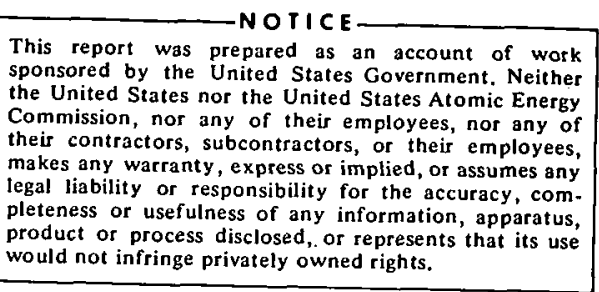

This report was prepared as an account of wark sponsored by the United States Government. Neither Commission, nor any of their employes nor any of their contractors, subcontractors, or their employees,

legal liability or rexpress or implied, or assumes any

pleteness or usefulness of any information, apparatus, would not infringe privately owned rights.

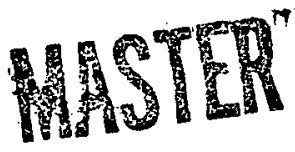




\begin{abstract}
Recorded test data are presented for Tests 1001, 1002, and 1003 of the isothermal portion of the Semiscale Blowdown and Emergency Core Cooling (ECC) Project. Although the major emphasis in the isothermal blowdown experiments was on ECC delivery, these first tests were conducted without injection of simulated ECC in order to establish the baseline system behavior and to determine the effects of lower plenum geometry and heat transfer characteristics. The data, presented in the form of composite graphs in engineering units, have been analyzed only to the extent necessary to assure that they are reasonable and correct. The intent of this report is to make available the uninterpreted data from Tests 1001,1002 , and 1003 for use by others and for support of subsequent interpretative reports and analyses.
\end{abstract}




\section{SUMMARY}

Tests 1001,1002 , and 1003 were the first tests performed in the isothermal portion of the Semiscale Blowdown and Emergency Core Cooling (ECC) Project conducted by Aerojet Nuclear Company for the Atomic Energy Commission. These decompression tests were conducted without simulated ECC injection to establish baseline system behavior and to determine the effects of lower plenum geometry and heat transfer characteristics. The experimental system consisted of a pressure vessel with simulated reactor internals; an operating loop with pump, steam generator, and pressurizer; a blowdown loop with a simulated pump, a simulated steam generator, and rupture assemblies; and a pressure suppression șystem with header and pressure suppression tank.

Each of the three tests was initiated from isothermal conditions of about $2250 \mathrm{psig}$ and $575^{\circ} \mathrm{F}$ by a simulated instantaneous large cold leg pipe break. Test 1001 provided data for establishing the reference system hydraulic behavior during sudden decompression. Test 1002 provided data for establishing the effects of the lower plenum heat transfer characteristics on the water remaining in the lower plenum following blowdown. Test 1003 provided data for establishing the effect on the water remaining in the lower plenum of altering the lower plenum geometry. For Test 1003, the length-to-diameter ratio of the lower plenum was 1.2:1 as compared with $2.8: 1$ for Tests 1001 and 1002 .

In general, instrumentation used in Tests 1001, 1002, and 1003 functioned as intended and data loss was minimal: Of more than 400 measurements attempted during these three tests, more than $90 \%$ were accomplished. The data appear to be satisfactory for subsequent analysis. 
ABSTRACT ......................

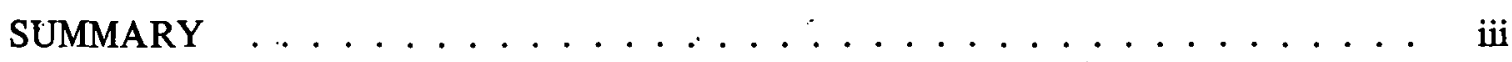

I. INTRODUCTION $\ldots \ldots \ldots \ldots \ldots$

II. SYSTEM AND CONDITIONS FOR TESTS 1001, 1002, AND $1003 \ldots \ldots$

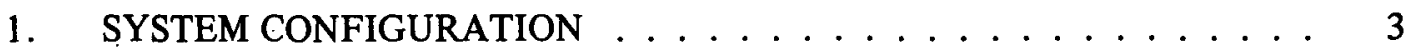

2. INITIAL TEST CONDITIONS $\ldots \ldots \ldots \ldots$

3. EVENTS FOLLOWING RUPTURE . . . . . . . . . . . . . 5

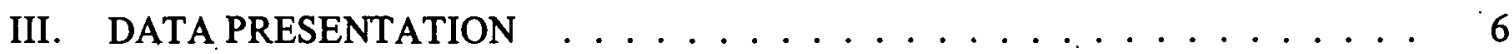

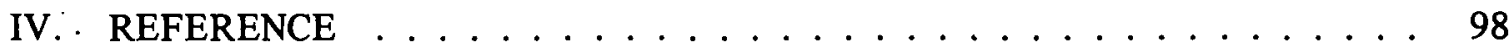

\section{FIGURES}

1. 1-1/2-loop semiscale system and instrumentation - isometric . . . . . . 7

2. 1-1/2-loop semiscale system and instrumentation - schematic ....... 8

3. Pressure vessel - cross-sectional view showing instrumentation . . . . . . 9

4. Pressure vessel - isometric showing instrumentation . . . . . . . . . . . 10

5. Fluid temperatures in operating loop - Test $1001 \ldots \ldots 17$

6. Fluid temperatures in operating loop - Test $1002 \ldots \ldots 17$

7. Fluid temperatures in operating loop - Test $1003 \ldots \ldots 18$

8. Fluid temperatures in blowdown loop - Test $1001 \ldots \ldots$. . . . . . 18

9. Fluid temperatures in blowdown loop - Test 1002 . . . . . . . . . . 19

10. Fluid temperatures in blowdown loop - Test $1003 \ldots \ldots 19$

11. Fluid temperatures in pressure suppression system - Test $1001 \ldots 20$

12. Fluid temperatures in pressure suppression system - Test $1002 \ldots$. . . . . 20

13. Fluid temperatures in pressure suppression system - Test $1003 \ldots 21$ 
14. Fluid temperatures in lower plenum at thermocouple rack - Test $1001 \ldots 21$

15. Fluid temperatures in lower plenum at thermocouple rack -- Test $1002 \ldots$. . . . 22

16. Fluid temperatures in lower plenum at thermocouple rack -- Test $1003 \ldots 22$

17. Fluid temperatures in downcomer gap and outlet plenum - lest $1001 \ldots 23$

18. Fluid temperatures in downcomer gap and outlet plenum - Test $1002 \ldots 23$

19. Fluid temperatures in downcome gap - Test $1003 \ldots \ldots 24$

20. Metal temperatures in core barrel - Test $1001 \ldots \ldots 24$

21. Metal temperatures in core barrel - Test $1002 \ldots \ldots . \ldots 25$

22. Metal temperatures in core barrel - Test $1003 \ldots \ldots$. . . . . . . . 25

23. Metal temperalures in downcomer filler - Test $1001 \ldots 26$

24. Metal temperatures in downcomer filler - Test $1002 \ldots \ldots$. . . . . . 26

25. Metal temperatures in downcomer filler - Test $1003 \ldots \ldots 27$

26. Metal temperatures in vessel wall 95 inches from vessel upper flange

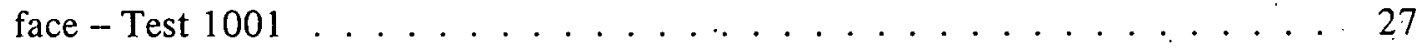

27. Metal temperatures in vessel wall 95 inches from vessel upper flange face - Test $1002 \ldots \ldots \ldots \ldots \ldots$. . . . . . . . . . . . . . . . . . . . . .

28. Metal temperatures in vessel wall 95 inches from vessel upper flange face - Test $1003 \ldots \ldots \ldots \ldots$. . . . . . . . . . . . . . . . . . . .

29. Metal temperatures in vessel wall - Test $1002 \ldots \ldots$. . . . . . . . . 29

30. Metal temperatures in vessel wall - Test $1003 \ldots \ldots$. . . . . . . . . . 29

31. Metal temperatures in vessel wall - Test 1003 (separation of Figure 30 for TM-210-S, TM-210-18, and TM-210-316) . . . . . . . . 30 .

32. Metal temperatures in vessel wall - Test 1003.(separation of Figure 30 for TM-205-S, TM-205-18, TM-205-316, TM-250-S, TM-250-18, and

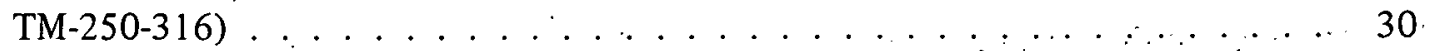

33. Metal temperatures in lower plenum vessel wall -- Test $1001 \quad \ldots \ldots \ldots . . . .31$

34. Metal temperatures in lower plenum vessel wall - Test $1002 \ldots \ldots$. . . . . . 3

35. Metal temperatures in lower plenum vessel wall - Test $1003 \ldots \ldots 2$ 
36. Metal temperatures in operating loop hot leg Spool $1-$ Test $1001 \ldots 32$

37. Metal temperatures in operating loop hot leg Spool l- Test $1002 \ldots 33$

38. Metal temperatures in operating loop cold leg Spool 19 - Test $1001 \ldots 33$

39. Metal temperatures in operating loop cold leg Spool 19 -- Test $1002 \ldots 34$

40. Metal temperatures in operating loop cold leg Spool 19 - Test $1003 \ldots 34$

41. Metal temperatures in operating loop cold leg Spool 22 - Test $1001 \ldots 35$

42. Metal temperatures in operating loop cold leg Spool 22 - Test $1002 \ldots 35$

43. Metal temperatures in operating loop cold leg Spool 22 - Test 1003 . . . . . 36

44. Metal temperatures in pressure suppression system - Test $1001 \ldots 36$

45. Momentum flux from drag disćs in operating loop hot leg - Test $1001 \ldots 37$

46. Momentum flux from drag discs in operating loop hot leg - Test $1002 \ldots 37$

47. Momentum flux from drag discs in operating loop hot leg - Test $1003 \ldots 38$

48. Momentum flux from drag discs in operating loop cold leg -- Test $1001 \ldots 38$

49. Momentum flux from drag discs in operating loop cold leg - Test $1002 \ldots 39$

50. Momentum flux from drag discs in operating loop cold leg -- Test 1003

(FD-15 and FD-22) . . . . . . . . . . . . . . . 39

51. Momentum flux from drag discs in operating loop cold leg - Test 1003 $(\mathrm{FD}-19) \ldots \ldots \ldots \ldots \ldots \ldots$. . . . . . . . . . . . . . . . . .

52. Momentum flux from drag discs in blowdown loop - Test $1001 \ldots 40$

53. Momentum flux from drag discs in blowdown loop - Test $1002 \ldots 41$

54. Momentum flux from drag discs in blowdown loop - Test 1003 (FD-70 and : FD-76) .......................... 41

55. Momentum flux from drag discs in blowdown loop - Test 1003 (FD-50) $\because \therefore \quad 42$

56. Momentum flux from drag discs at core barrel inlet - Test $1001 \ldots 42$

57. Momentum flux from drag discs at core barrel inlet - Test $1002 \ldots \ldots$

58. Momentum flux from drag discs at core barrel inlet -- Test $1003 \ldots$. . . . . . 43 
59. Volumetric flow rate from turbine meters in operating loop -- Test $1001 \ldots 44$

60. Volumetric flow rate from turbine meters in operating loop - Test $1002 \ldots 44$

61. Volumetric flow rate from turbine meters in operating loop - Test $1003 \ldots 45$

62. Volumetric flow rate from turbine meter in blowdown loop hot leg - Test 1001. 45

63. Volumetric flow rate from turbine meter in blowdown loop hot leg - Test 1002 . 46

64. Volumetric flow rate from turbine meter at core barrel inlet - Test $1001 \ldots 46$

65. Volumetric flow rate from turbine meter at core barrel inlet - Test $1003 \ldots 47$

66. Volumetric flow rate from turbine meter at pressurizer outlet - Test $1001 \ldots 47$

67. Volumetric flow-rate from turbine meter at pressurizer outlet - Test $1003 \ldots 48$

68. Fluid velocity from turbine meters in downcomer gap -- Test $1001 \ldots$. . . . 48

69. Mass flow rate in operating loop hot leg Spool 1 -- Test $1001 \ldots \ldots$. . . . . 49

70. Mass flow rate in operating loop hot leg Spool 1 -- Test $1002 \ldots \ldots$. . . . . 49

71. Mass flow rate in operating loop hot leg Spool 1 -- Test $1003 \ldots \ldots$. . . . . . 50

72. Mass. flow rate in operating loop at pump discharge (Spool 19) - Test $1001 \ldots 50$

73. Mass flow rate in operating loop at pump discharge (Spool 19) -- Test 1002 . . . 51

74. Mass flow rate in operating loop at pump discharge (Spool 19) - Test 1003 . . 51

75. Mass flow rate in operating loop cold leg Spool 22 - Test $1001 \ldots \ldots 2$

76. Mass flow rate in operating loop cold leg Spool 22 - Test $1002 \ldots \ldots 2$

77. Mass flow rate in operating loop cold leg Spool 22 -- Test $1003 \ldots$. . . . . . 53

78. Mass flow rate in operating loop Spools 5 and 15 -- Test $1001 \ldots \ldots 3$

79. Mass flow rate in operating loop Spools 5 and 15 - Test $1002 \ldots \ldots 4$

80. Mass flow rate in operating loop Spools 5 and $15-$ Test $1003 \ldots \ldots 54$

81. Mass flow rate in blowdown loop Spool 70 - Test $1001 \ldots \ldots 5$

82. Mass flow rate in blowdown loop Spool $70 \div$ Test $1002 \ldots \ldots 5$

83. Mass flow rate in blowdown loop Spool 70 - Test $1003 \ldots \ldots \ldots$ 
84. Mass flow rate in blowdown loop Spools 50 and 76 - Test $1001 \ldots 56$

85. Mass flow rate in blowdown loop Spools 50 and 76 - Test $1002 \ldots 57$

86. Mass flow rate in blowdown loop Spools 50 and 76 - Test $1003 \ldots 57$

87. Mass flow rate at core barrel inlet - Test $1001 \ldots \ldots$. . . . . . . 58

88. Mass flow rate at core barrel inlet - Test $1002 \ldots \ldots$. . . . . . . 58

89. Mass flow rate at core barrel inlet - Test $1003 \ldots \ldots$. . . . . . . 59

90. Fluid density in operating loop hot leg-Test $1001 \ldots \ldots$

91. Fluid density in operating loop hot leg - Test $1002 \ldots \ldots 0$

92. Fluid density in operating loop hot leg - Test $1003 \ldots \ldots 0$

93. Fluid density at operating loop pump inlet and outlet - Test $1001 \ldots 61$

94. Fluid density at operating loop pump inlet and outlet - Test $1002 \ldots 61$

95. Fluid density at operating loop pump inlet and outlet - Test $1003 \ldots 62$

96. Fluid density in operating loop cold leg - Test $1001 \ldots \ldots 2$

97. Fluid density in operating loop cold leg - Test $1002 \ldots 63$

98. Fluid density in operating loop cold leg - Test $1003 \ldots 63$

99. Fluid density in blowdown loop - Test $1001 \ldots \ldots 4$

100. Fluid density in blowdown loop - Test $1002 \ldots \ldots$. . . . . . . . 64

101. Fluid density in blowdown loop - Test $1003 \ldots \ldots$. . . . . . . . 65

102. Fluid density in vessel - Test $1001 \ldots \ldots \ldots \ldots$

103. Fluid density in vessel - Test $1002 \ldots \ldots \ldots 6 \ldots$

104. Fluid density in vessel - Test $1003 \ldots \ldots 66$

105. Fluid density in pressure suppression header - Test $1001 \ldots 67$

106. Fluid density in pressure suppression header - Test $1002 \ldots$. . . . . . 67

107. Fluid density in pressure suppression header - Test $1003 \ldots 68$

108. Pressure in operating loop - Test 1001 $\ldots \ldots \ldots$ 
109. Pressure in operating loop -- Test $1002 \ldots \ldots 6$

110. Pressure in opcrating loop -- Test $1003 \ldots \ldots 9$

111. Pressure in blowdown loop - Test $1001 \ldots \ldots 70$

112. Pressure in blowdown loop -- Test $1002 \ldots \ldots$. . . . . . . . . 70

113. Pressure in blowdown loop - Test $1003 \ldots \ldots \ldots$. . . . . . . . 71

114. Pressure in vessel - Test $1001 \ldots \ldots \ldots$. . . . . . . . . . . 71

115. Pressure in vessel - Test $1002 \ldots \ldots 72$

116. Pressure in vessel - Test $1003 \ldots \ldots$. . . . . . . . . . . 72

117. Pressure in pressure suppression system -- Test $1001 \ldots \ldots 73$

118. Pressure in pressure suppression system -- Test $1002 \ldots \ldots 73$

119. Pressure in pressure suppression system -- Test 1003 (P-80 and P-83) ........................ 74

120. Pressure in pressure suppression system -- Test 1003 (P-77 and P-89) . . . . . . . . . . . . . . . . . . 74

121. Pressure at hot leg stub in upper plenum (LOFT free field pressure transducer) -- Test 1001

122. Pressure at hot leg stub in upper plenum (LOFT free field pressure transducer) - Test 1002

123. Differential pressure across operating loop (DP-22-1) -- Tests 1001, 1002 , and 1003

124. Differential pressure, operating loop hot leg (DP-1-5) -- Tests 1001, 1002 , and 1003

125. Differential pressure, operating loop hot leg (DP-3-5) - Tests 1002 and 1003

126. Differential pressure across steam generator (DP-5-13) -- Tests 1001, 1002 , and 1003

127. Differential pressure across pump suction orifice (DP-8-13) - Tests 1001,1002 , and $1003 \ldots \ldots \ldots$

128. Differential pressure across operating loop pump inlet (DP-13-15) -Test 1001 
129. Differential pressure across operating loop pump (DP-19-15) -- Tests

1001,1002 , and $1003 \ldots \ldots \ldots \ldots$

130. Differential pressure across operating loop pump, low range (DP-19-15L) --

Tests 1001,1002 , and 1003

131. Differential pressure across operating loop cold leg (DP-19-22) - Tests

1001,1002 , and 1003

132. Differential pressure between cold leg and lower plenum (DP-22-255) - Tests

1001,1002 , and 1003

133. Differential pressure across core (DP-255-207) - Tests 1001 and $1002 \ldots 8$

134. Differential pressure across upper portion of downcomer (DP-213-246) - Tests

1001,1002 , and 1003

135. Differential pressure across middle portion of downcomer (DP-246-249) -- Tests 1001,1002 , and $1003 \ldots \ldots \ldots$

136. Differential pressure across lower portion of downcomer (DP-249-255) -- Tests 1001,1002 , and $1003 \ldots \ldots \ldots$

137. Differential pressure across lower plenum (DP-261-255) -- Tests 1001, 1002 , and 1003

138. Differential pressure across vessel (DP-LOFT) -- Tests 1001, 1002, and $1003 \ldots 83$

139. Differential pressure between vessel upper plenum and blowdown loop hot leg (DP-207-70) -- Tests 1001 and 1002

140. . Differential pressure between vessel inlet annulus and blowdown loop cold leg (DP-264-50) -- Tests 1001, 1002, and 1003

141. Differential pressure across blowdown loop hot leg nozzle (DP-76-61) -- Tests 1001,1002 , and 1003

142. Differential pressure between simulated pump and throat of blowdown loop hot leg nozzle (DP-76-HN2) - Tests 1001, 1002, and 1003

143. Differential pressure across simulated pump (DP-96-76) -- Tests

1001 and 1003

144. Differential pressure across simulated steam generator (DP-70-96) - Tests 1001,1002 , and 1003

145. Differential pressure across blowdown loop cold leg nozzle diverging section (DP5-HN2-HN4) - Tests 1001, 1002, and 1003

146. Differential pressure across blowdown loop hot leg nozzle diverging section (DP6-HN2-HN4) - Tests 1001, 1002, and 1003 
147. Differential pressure across blowdown loop hot leg nozzle, Station 61

(DP-HN4-61) - Tests 1001, 1002, and 1003 . . . . . . . . . .

148. Differential pressure between vessel upper plenum and pressure suppression lank vapor chamber (DP-207-89) - Tests 1001, 1002, and 1003

149. Differential pressure between pressure suppression header and pressure suppression tank vapor chamber (DP-81-89) -- Tests 1001, 1002, and $1003 \ldots$

150. Differential pressure between pressure suppression tank downcomer entrance and exit (DP-83-85) - Tests 1001, 1002, and 1003 . . . . . . . . .

151. Differential pressure between pressure suppression tank downcomer entrance and pressure suppression tank vapor chamber (DP-83-89) - Tests 1001, 1002,

152. Differential pressure between pressure suppression tank downcomer exit and pressure suppression tank vapor chamber (DP-85-89) - Tests 1001, 1002, and 1003

153. Liquid level in pressure suppression tank - Test $1001 \ldots . \ldots$. . . . . . 91

154. Pump speed-Test $1001 \ldots \ldots \ldots 1$

155. Pump speed - Test $1002 \ldots \ldots$. . . . . . . . . . . . . 92

156. Pump speed - Test $1003 \ldots \ldots$. . . . . . . . . . . . . . . .

157. Pump power-Test $1001 \ldots \ldots \ldots$. . . . . . . . . . . . . 93

158. Pump power - Test $1002 \ldots \ldots \ldots \ldots$. . . . . . . . . . . . . . .

159. Pump power - Test $1003 \ldots \ldots . \ldots \ldots 4$

160. Pump torque -- Test $1001 \ldots \ldots \ldots$. . . . . . . . . . . . 94

161. Pump torque - Test $1002 \ldots \ldots \ldots 5$

162. Pump torque - Test $1003 \ldots \ldots \ldots 5$

163. Displacement of pressure suppression header - Test $1001 \ldots 96$

164. Displacement of pressure suppression header - Test $1002 \ldots$. . . . . . . . 96

165. Displacement of pressure suppression header - Test $1003 \ldots \ldots 7$ 


\section{TABLES}

I. Conditions at Blowdown Initiation $(\mathrm{t}=0$ seconds $) \ldots \ldots \ldots$

II. Water Chemistry Prior to Blowdown ................ 5

III. Data Presentation for Isothermal Tests 1001, 1002, and 1003 . . . . . . 11 


\section{EXPERIMENT DATA REPORT FOR 1-1/2-LOOP SEMISCALE SYSTEM}

ISOTHERMAI. TFSTS 1001, 1002, AND 1003

\section{INTRODUC'TION}

The. isothermal blowdown test program is part of the Semiscale Blowdown and Emergency Core Cooling (ECC) Project conducted by Aerojet Nuclear Company. The project is part of an overall AEC-sponsored research and development program directed at (a) quantifying the physical processes controlling system behavior during a postulated loss-of-coolant accident (LOCA) in a pressurized water reactor (PWR), and (b) providing an experimental data base for assessing reactor safety evaluation models.

The 1-1/2-loop semiscale system in which the isothermal test program was conducted includes both an intact operating loop and a broken, or blowdown, loop. The operating loop simulates three unbroken loops of a PWR, and the blowdown loop simulates one broken loop of a PWR. Relative to previous experimental systems, the 1-1/2-loop semiscale system provides a source of more representative coupled-system response data from which to obtain a correspondingly more comprehensive understanding of the thermal and hydraulic processes during an LOCA.

The major emphasis in the isothermal blowdown experiments was on ECC delivery. However, Tests 1001, 1002, and 1003, the first series of tests in the isothermal test program, were conducted without simulated ECC injection to establish baseline system behavior and to determine the effects of lower plenum geometry and heat transfer characteristics. The tests were initiated from isothermal conditions of about 2250 psig and $575^{\circ} \mathrm{F}$ by an instantaneous large cold leg break. The length-to-diameter ratio of the lower plenum of the 1-1/2-loop semiscale vessel is somewhat larger than the ratio for a typical PWR. In order to establish baseline data for integral system effects, Test 1001 was conducted with the lower plenum of the standard semiscale geometry (length-to-diameter ratio of 2.8:1) and insulated with a thermal shield. Test 1002 was conducted with the lower plenum of the standard geometry $(\mathrm{L} / \mathrm{D}=2.8: 1)$ but with no thermal insulation to investigate the effects of increased lower plenum heat transfer. Test 1003 was conducted to investigate the effects of varied lower plenum geometry $(\mathrm{L} / \mathrm{D}=1.2: 1$, with thermal shield installed). The results of these tests together with those from other tests in the isothermal program are expected to provide the following: (a) a significant contribution to the existing coupled-effects data base for development and evaluation of LOCA analytical methods, (b) a basis for determining the applicability of the steady state countercurrent flow results obtained from separate-effects tests in the semiscale program (transparent vessel tests and steady state tests) for predicting blowdown behavior, and (c) a data base, including both separate-effects and coupled-effects results for countercurrent flow, for use with data from larger scale separate effects experiments (AEC-industry cooperative programs) to establish the effect of physical scaling. 
The test configuration and conditions for Tests 1001,1002 , and 1003 are summarized briefly as follows:

\section{Test 1001}

(1) Initial isothermal conditions were about $2260 \mathrm{psig}$ and $578^{\circ} \mathrm{F}$.

(2) The downcomer gap size was 0.5 inch.

(3) The standard (long) lower plenum configuration ( $\mathrm{L} / \mathrm{D}=2.8: 1$ ) was used with the thermal shield installed.

(4) The 100\% break area nozzles were used.

Test 1002

(1) Initial isothermal conditions were about $2262 \mathrm{psig}$ and $579^{\circ} \mathrm{F}$.

(2) The downcomer gap size was 0.5 inch.

(3) The standard (long) lower plenum configuration ( $\mathrm{L} / \mathrm{D}=2.8: 1$ ) was used but without the thermal shield installed.

(4) The 100\% break area nozzles were used.

$\underline{\text { Test } 1003}$

(1) Initial isothermal conditions were about $2245 \mathrm{psig}$ and $582^{\circ} \mathrm{F}$.

(2) The downcomer gap size was 0.5 inch.

(3) The short lower plenum configuration ( $\mathrm{L} / \mathrm{D}=2.8: 1$ ) was used with the thermal shield installed.

(4) The $100 \%$ break area nozzles were used. -

The purpose of this report is to present the test data in an uninterpreted, but readily usable, form for use by the nuclear community in advance of detailed analysis and interpretation. Section II briefly describes the system configuration, initial test conditions, and events and conditions following initiation of blowdown that are applicable to Tests 1001, 1002, and 1003. Section III presents the data graphs and provides comments and supporting information necessary for interpretation of the data. Reference 1 is recommended as an additional source of information regarding the isothermal experimental system and program; test conditions and procedures; instrument locations, nomenclature, and accuracies; and methods of obtaining and processing the data. 


\section{SYSTEM AND CONDITIONS FOR TESTS 1001, 1002, AND 1003}

The system configuration, initial test conditions, and events and conditions following blowdown initiation that are specific to Tests 1001, 1002, and 1003 are presented.

\section{SYSTEM CONFIGURATION}

The 1-1/2-loop isothermal semiscale system used for Tests 1001, 1002, and 1003 consisted of a pressure vessel with internals; an operating loop with steam generator, pump, and pressurizer; a blowdown loop with a simulated steam generator, a simulated pump, and two rupture assemblies; and a pressure suppression system with a suppression tank and a header.

For Tests 1001 and 1002, the standard lower plenum $(L / D=2.8: 1)$ was used. This plenum consists of the standard (long) lower head and the downcomer filler extension. For Test 1003 , the short lower plenum ( $\mathrm{L} / \mathrm{D}=1.2: 1$ ) was used; the volumes of the short lower plenum and the standard lower plenum are the same. For Tests 1001 and 1003, the lower plenum was thermally insulated with a thermal shield, which consists of a thermal sleeve and the bottom thermal liner plate. A vessel downcomer filler piece was used to provide a 0.5 -inch downcomer gap for the three tests. The system was subjected to a double-ended offset cold leg break by means of two rupture disc assemblies each employing $100 \%$ break area nozzles.

Sprays were used during Tests 1001 and 1002 as a means of controlling the pressure in the pressure suppression tank. A 3 -inch Schedule 40 flanged nozzle (with blind flange installed) in the top of the pressure suppression tank provided access to the spray equipment.

For Tests 1002 and 1003, two 1-1/2-inch vacuum breaker valves were provided to prevent suction of water up the downcomer after completion of blowdown. Performance of this system was marginal, and in Test 1001 the vacuum-breaker valves were replaced by. three 1-1/2-inch check valves ${ }^{[a]}$.

\section{INITIAL TEST CONDITIONS}

Conditions in the semiscale system at initiation of blowdown and the primary system water chemistry prior to blowdown are given in Tables I and II, respectively.

[a] Tests 1001, 1002, and 1003 were conducted in reverse order. 
CONDITIONS AT BLOWDOWN INITIATION ( $t=0$ seconds)

\begin{tabular}{|c|c|c|c|}
\hline Condition & $\begin{array}{l}\text { Test } \\
1001\end{array}$ & $\begin{array}{l}\text { Test } \\
1002 \\
\end{array}$ & $\begin{array}{l}\text { Test } \\
1003\end{array}$ \\
\hline Core outlet temperature $\left({ }^{\circ} \mathrm{F}\right)$ & 575 & 579 & 582 \\
\hline System flow rate (gpm) & 170 & 173 & 172 \\
\hline $\begin{array}{l}\text { System pressure at vessel outlet } \\
\text { (psig) }\end{array}$ & 2260 & 2260 & 2245 \\
\hline Pump differential pressure (psid) & 37.5 & 38.0 & 38.0 \\
\hline Suppression tank water level (in.) & 46 & 46 & .68 \\
\hline $\begin{array}{l}\text { Suppression tank water temperature } \\
\left({ }^{\circ} \mathrm{F}\right)\end{array}$ & 183 & 195 & 150 \\
\hline $\begin{array}{l}\text { Suppression tank water pressure } \\
\text { (psig) }\end{array}$ & 13.5 & 12.7 & Atmospheric \\
\hline $\begin{array}{l}\text { Suppression spray water temperature } \\
\left({ }^{\circ} \mathrm{F}\right)\end{array}$ & Not used & $\sim 70$ & $\sim 70$ \\
\hline Pressurizer water volume $\left(\mathrm{ft}^{3}\right)$ & Not available & 0.73 & 0.59 \\
\hline $\begin{array}{l}\text { Suppression tank water level } \\
\text { after blowdown (in.) }\end{array}$ & 92 & 54 & 86 \\
\hline $\begin{array}{l}\text { Suppression tank water pressure } \\
\text { after blowdown (psig) }\end{array}$ & $48^{[a]}$ & $46^{[\mathrm{b}]}$ & $23^{[b]}$ \\
\hline \multicolumn{4}{|c|}{ [a] At $22 \mathrm{sec}$ after blowdown initiation. } \\
\hline \multicolumn{4}{|c|}{ [b] At $30 \mathrm{sec}$ after blowdown initiation. } \\
\hline
\end{tabular}


TABLE II

WATER CHEMISTRY PRIOR TO BLOWDOWN

\begin{tabular}{|c|c|c|c|}
\hline & Test 1001 & Test 1002 & Test 1003 \\
\hline $\mathrm{pH}$ & 6.3 & 8.0 & 5.6 \\
\hline Chlori.des (ppm) & 0.22 & 0.73 & 6.8 \\
\hline Conductivity ( $\mu$ mhos) & 22 & 36 & 115 \\
\hline Suspended solids (ppm) & 0.8 & 9.2 & $<1.0$ \\
\hline $\mathrm{H}_{2}(\mathrm{cc} / \mathrm{l})$ & 0.7 & 4.7 & 0.4 \\
\hline $\mathrm{o}_{2}(\mathrm{cc} / 1)$ & $<0.1$ & 59.0 & 0.8 \\
\hline $\mathrm{N}_{2}(\mathrm{cc} / 1)$ & 4.5 & 267.4 & 4.3 \\
\hline A. $(c c / 1)$ & Not recorded & 2.9 & $<0.1$ \\
\hline $\mathrm{CO}_{2}(\mathrm{cc} / 1)$ & 0.8 & 0.1 & 5.1 \\
\hline Total Gas $(c c / 1)$ & 6.0 & 334.0 & 10.7 \\
\hline
\end{tabular}

\section{EVENTS FOLL.OWING RUPTURE}

The sequence of events as recorded following rupture is as follows:

Time after Rupture (seconds, except as noted)

\begin{tabular}{lll}
\multicolumn{3}{c}{ Time after Rupture } \\
(seconds, except as noted)
\end{tabular}

Lower plenum drained

of water

[a] Spray rate was $1.2 \mathrm{gpm}$ for Test 1002 and $1.0 \mathrm{gpm}$ for Test 1003; sprays were not used for. Test 1001 . 
The data from semiscale isothermal Tests 1001, 1002, and 1003 are presented with brief comment. Processing and analysis have been performed only to the extent necessary to obtain appropriate engineering units and to assure that the data are reasonable and correct. In all cases, in converting transducer output to engineering units, a homogeneous fluid was assumed. Further interpretation and analysis should consider that sudden decompression processes such as those occurring in the isothermal tests may have subjected the measurement devices to nonhomogeneous fluid conditions.

Figures 1 through 4 and Table III provide supporting information for interpretation of the data graphs shown in Figures 5 through 165. Figures 1 through 4 show the locations of all measurements in the isothermal system. Table III groups the measurements taken during the tests according to measurement type; identifies the specific ineasurements, their locations, and the range over which the data are considered valid; provides brief comments regarding the data; and references the measurements and comments to the corresponding figure on which the data are presented. The data are prescnted in some instances in the form of composite graphs to facilitate comparison of a given variable at several locations during a single test or a given variable during the three tests. Zero seconds on all graphs is the time of blowdown initiation.

Reference 1 provides more detailed information regarding the isothermal experimental system and program; test conditions and procedures; instrument locations, nomenclature, and accuracies; and methods of obtaining and processing the data. 


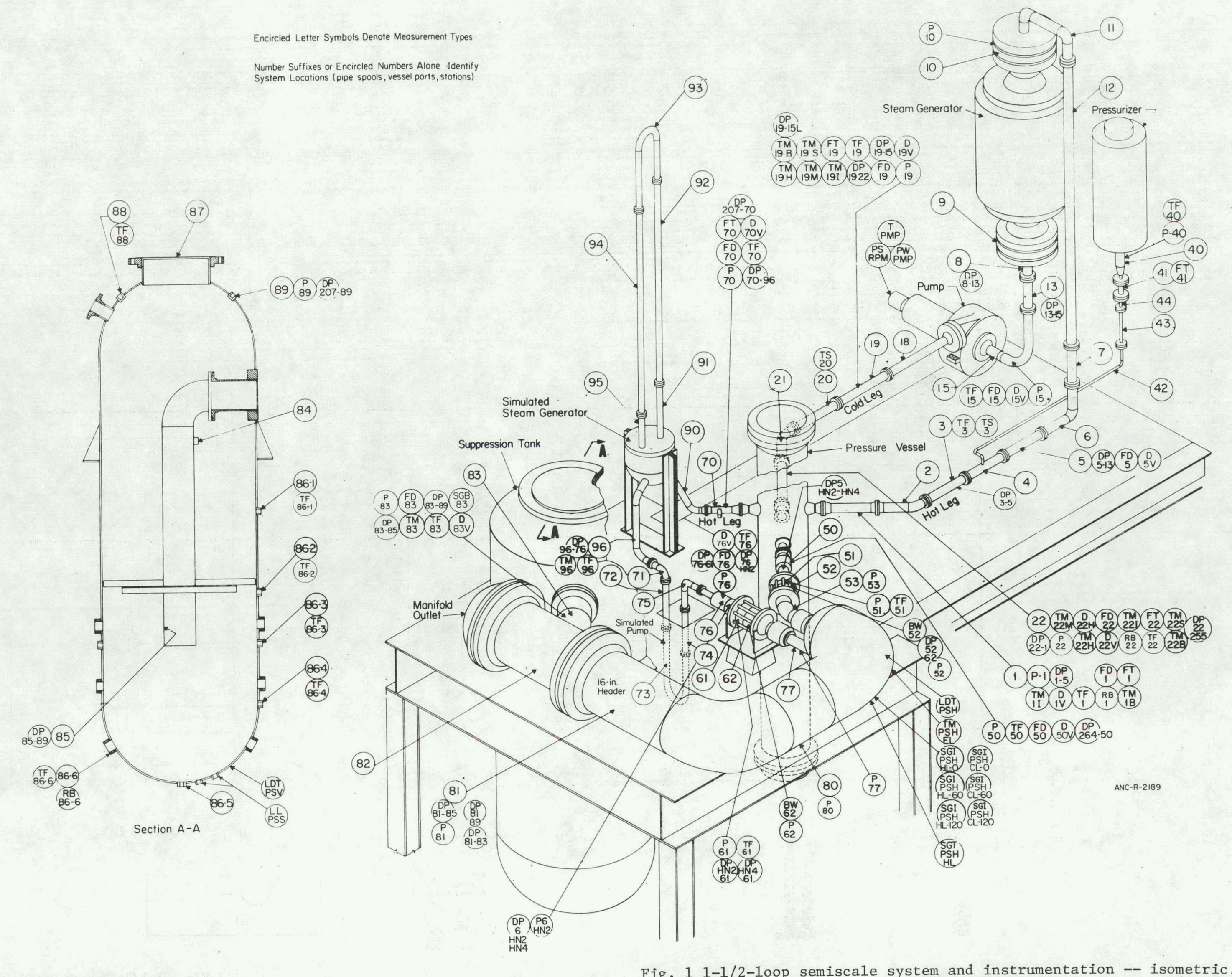




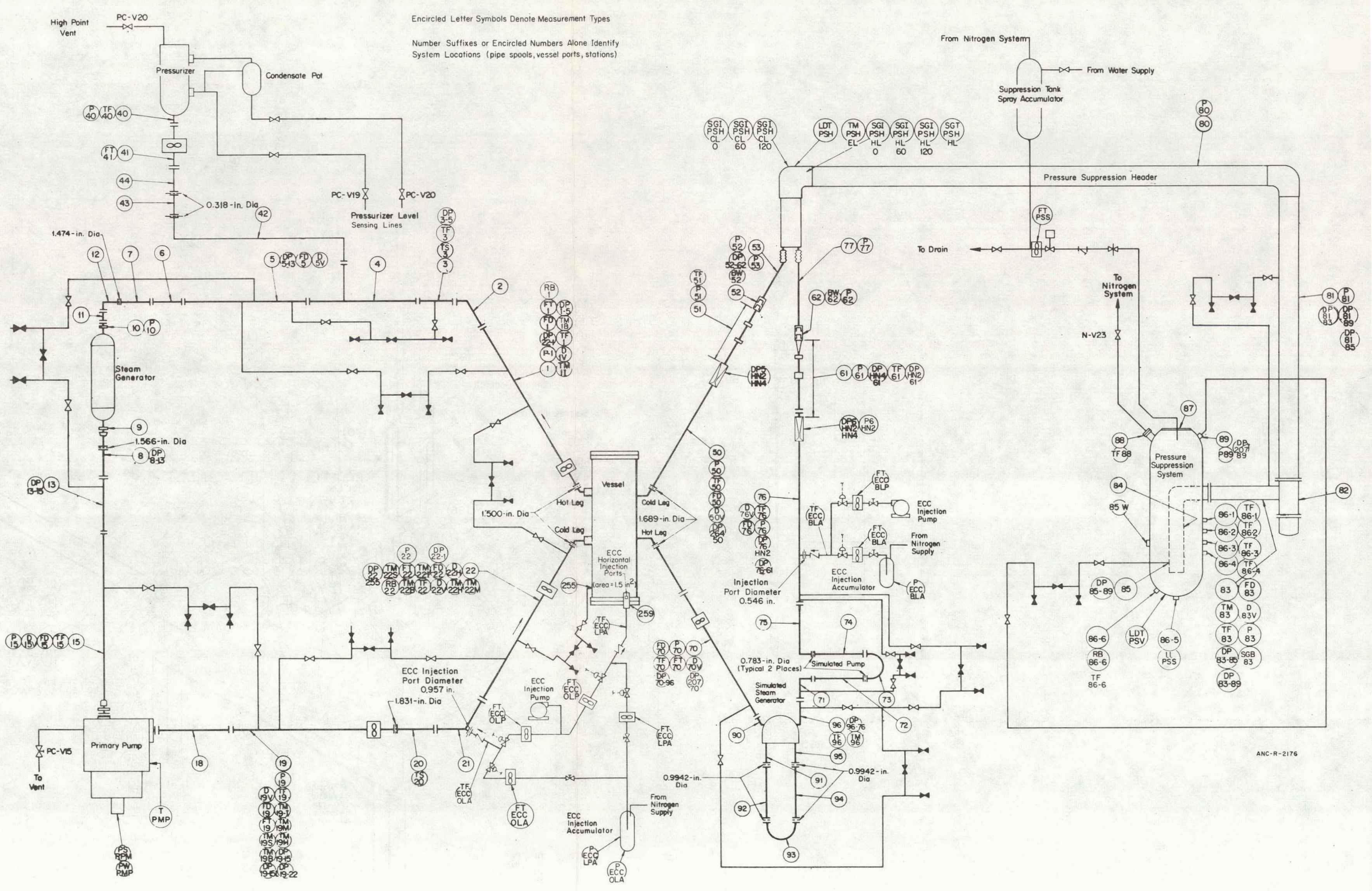

Fig. 2 1/1-2-1oop semiscale system and instrumentation.-- schemaut. 


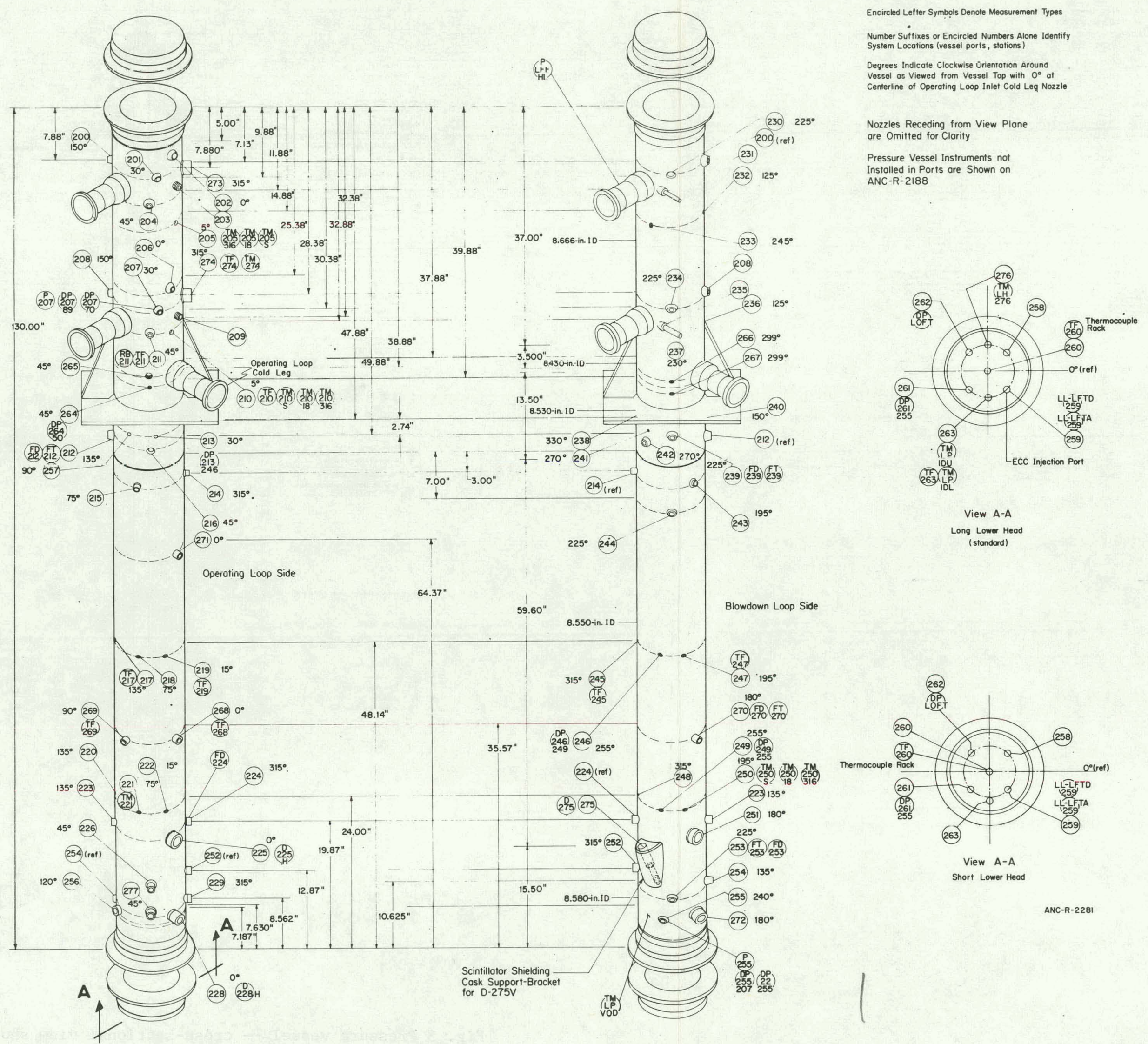

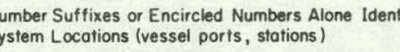

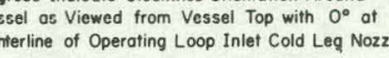

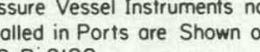

Fig. 4 Pressure vessel -- isometric showing instrument

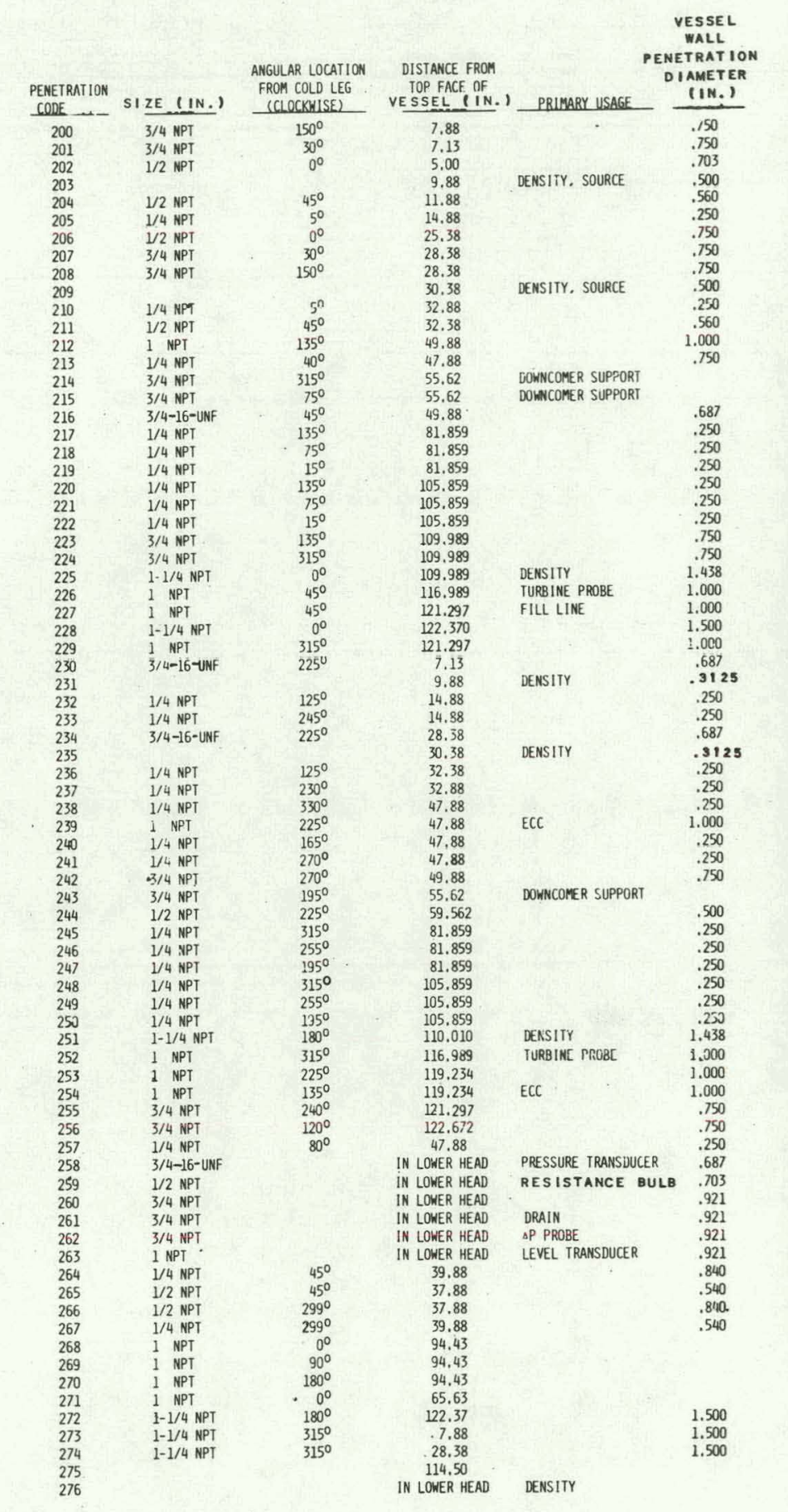




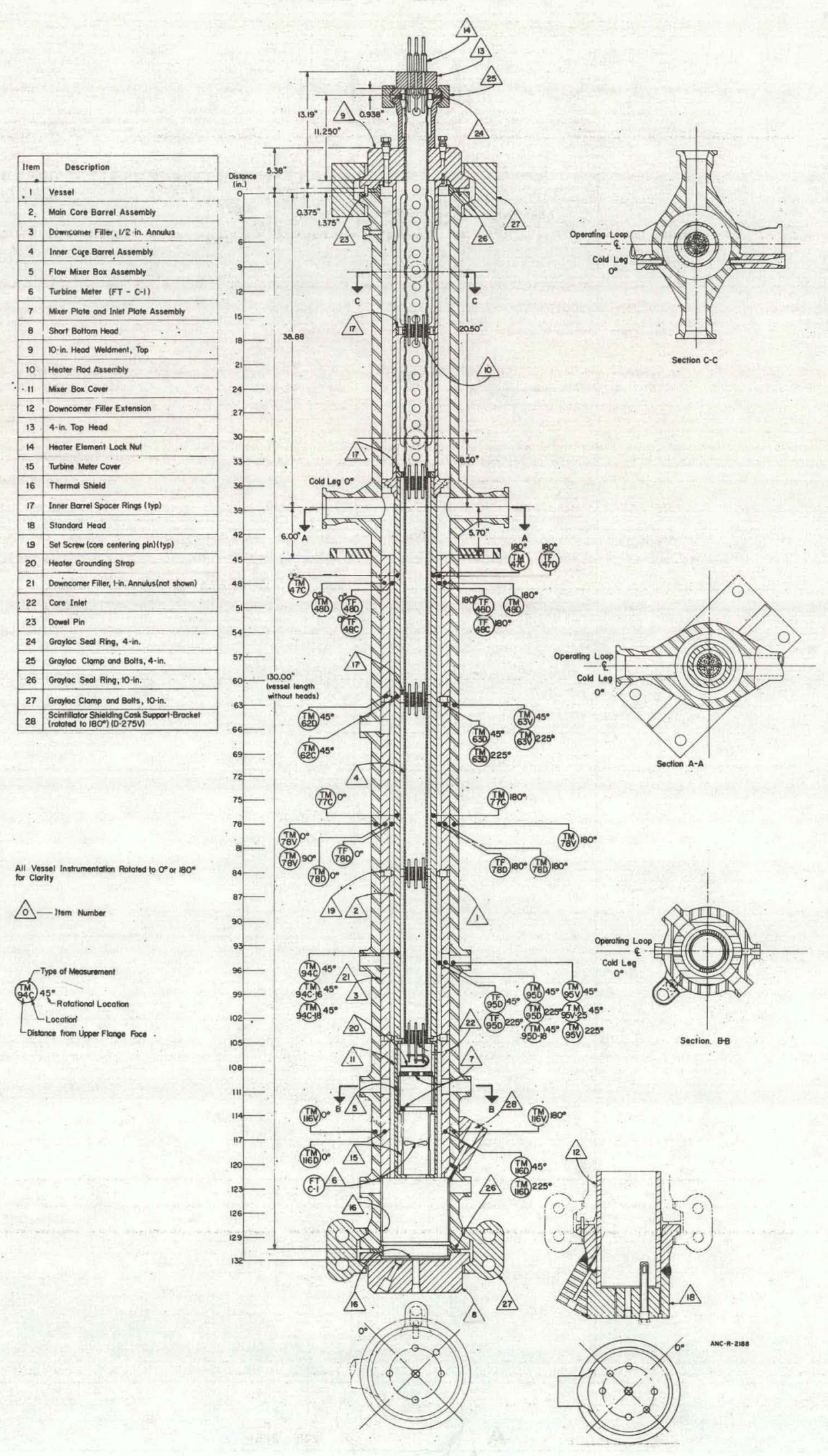

Fig. 3 Pressure vesse1 -- cross-sectional view showing instrumentation. 
TABLE III

DATA PBESENTATION FOR ISOTHERMAL TESTS 1001, 1002, AND 1003

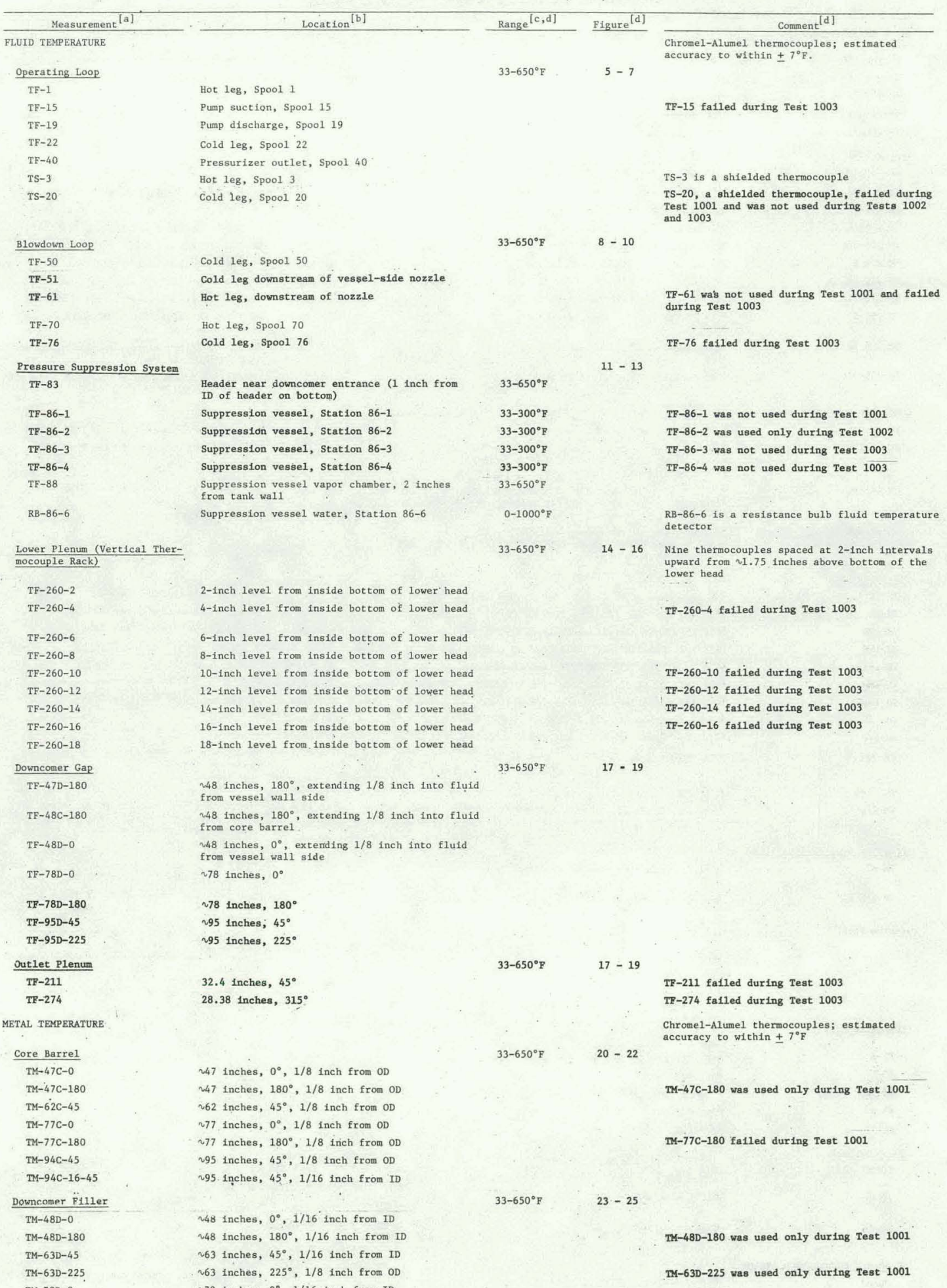


TABLE III (contd.)

DATA PRESENTATION FOR ISOTHERMAL TESTS 1001, 1002, AND 1003

TABLE 111 (contd.)

DATA PRESENTATION FOR ISOTHERMAI, TESTS 1001, 1002, AND 1003

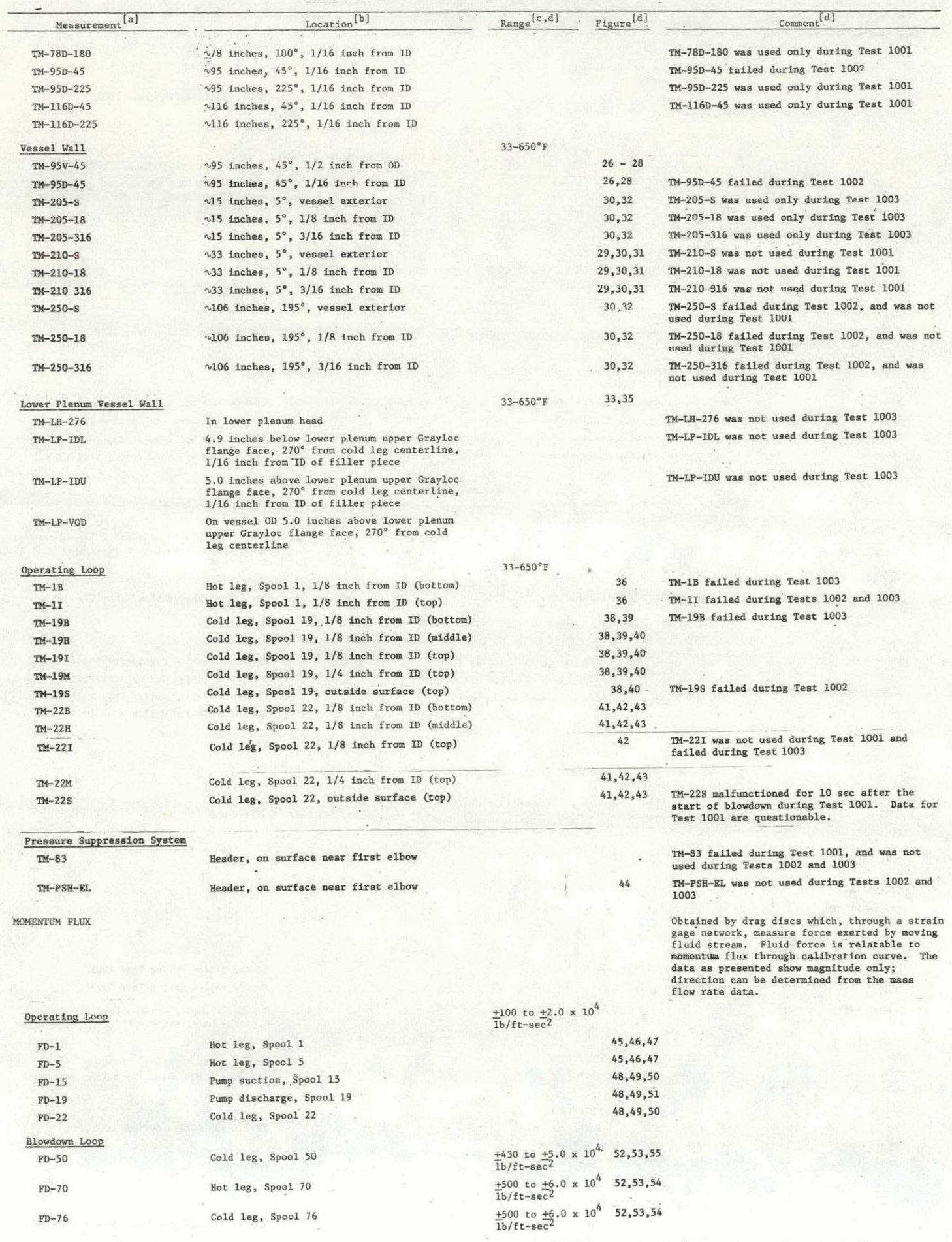

Pressure Suppression System FD-83 
TABLE III (contd.)

DATA PRESENTATION FOR ISOTHERMAL TESTS 1001. 1002, AND 1003

TABLE III (contd.)

DATA PRESENTATION FOR ISOTHERMAI TESTS 1001, 1002, AND 1003

\begin{tabular}{|c|c|c|c|c|c|}
\hline \multicolumn{2}{|c|}{ Measurement $^{[a]}$} & Location $^{[\mathrm{b}]}$ & Range $^{[c, d]}$ & \multirow[t]{2}{*}{ Figure ${ }^{[d]}$} & Comment $^{[d]}$ \\
\hline \multicolumn{5}{|c|}{ Vesse1 Downcomer Gap } & \\
\hline FD-212 & & 49.88 inches, $135^{\circ}$ & & & $\begin{array}{l}\text { Not reported; system was not callbrated. } \\
\text { Detectors were used only during Test } 1002\end{array}$ \\
\hline FD-239 & & 47.88 inches, $225^{\circ}$ & & & \\
\hline FD -253 & & 119.23 inches, $225^{\circ}$ & & & \\
\hline FD-270 & & 94.43 inches, $180^{\circ}$ & & & \\
\hline \multicolumn{6}{|c|}{ Core Barrel Inlet } \\
\hline FD-224 & & 110 inches, $315^{\circ}$ (target centered in gap) & $\frac{+140 \cdot \text { to } \pm 3.0 \times 10^{4}}{1 b / f t-\sec ^{2}}$ & ${ }^{4} 56-58$ & \\
\hline \multicolumn{3}{|c|}{ VOLUMETRIC FLOW RATE } & & & Obtained by turbine flowneters \\
\hline \multicolumn{2}{|c|}{ Operating Loop } & & \pm 40 to $\pm 800 \mathrm{gpm}$ & $59-61$ & \\
\hline \multicolumn{2}{|c|}{$\mathrm{FT}-1$} & Hot leg, Spool 1 & & & FT-1 failed during Test 1002 \\
\hline \multicolumn{2}{|l|}{ PT -19} & Pump discharge, Spool 19 & & & FT-19 failed during Tests 1001, 1002, and 1003 \\
\hline \multicolumn{2}{|l|}{ FT-22 } & Hot 1 eg, Spool 70 & & & \\
\hline \multicolumn{6}{|c|}{ Blowdown Loop } \\
\hline \multicolumn{2}{|c|}{ FT-70 } & Hot leg, Spool 70 & $\pm 20 \mathrm{lu} \pm 500 \mathrm{gpa}$ & 62,63 & FT-70 failed during Test 1003 \\
\hline \multicolumn{6}{|c|}{ Core Barre1 Inlet } \\
\hline \multicolumn{2}{|c|}{ FT-C-1 } & 110 inches from upper vessel flange face & \pm 40 to $\pm 300 \mathrm{gpm}$ & 64,65 & FT-C-1 falled during Test 1002 \\
\hline \multicolumn{6}{|c|}{ Pressurizer } \\
\hline \multicolumn{2}{|c|}{ FT -41} & Outlet, Spool 41 & \pm 8 to $\pm 200 \mathrm{gpm}$ & 66,67 & FT-41 failed during Test 1002 \\
\hline \multicolumn{6}{|c|}{ FLUID VELOCITY } \\
\hline \multicolumn{2}{|c|}{ Vessel Downcomer Gap } & & \pm 1 to $\pm 10 \mathrm{ft} / \mathrm{sec}$ & 68 & \\
\hline \multirow{2}{*}{\multicolumn{2}{|c|}{$\begin{array}{l}\text { FT-212 } \\
\text { FT-239 }\end{array}$}} & 49.88 inches, $135^{\circ}$ & & & FT-212 was not used during Tests 1002 and 1003 \\
\hline & & 47.88 Inches, $225^{\circ}$ & & & FT-239 was not used during Tests 1002 and 1003 \\
\hline \multicolumn{2}{|l|}{ FT-253 } & 119.23 inches, $225^{\circ}$ & & & FT-253 was not used during Tests 1002 and 1003 \\
\hline \multicolumn{2}{|l|}{ FT-270 } & 94.43 inches, $180^{\circ}$ & & & FT-270 was not used during Tests 1002 and 1003 \\
\hline MASS FLOW $R$ & ATE & & & & $\begin{array}{l}\text { Mass flow rate obtained by conbining density } \\
\text { (gamma attenuation technique) with volumetric } \\
\text { flow rate (turbine flowneters) or with momentur } \\
\text { flux (drag disc) }\end{array}$ \\
\hline Operating & Loop & & $\begin{array}{l}\text { Momentum flux: } \pm 100 \\
\text { to } \pm 2.0 \times 10^{4} 1 \mathrm{~b} / \mathrm{ft} \\
\text { volumetric f10w: } \pm \\
+800 \mathrm{gpm} \\
\frac{\mathrm{g} m}{\text { density }}: 0.05 \text { to } 6 \\
1 \mathrm{bm} / \mathrm{ft}\end{array}$ & $\begin{array}{l}\text { ft } \\
\mathrm{ft}-\mathrm{sec}^{2} \\
+40 \text { to } \\
62.4\end{array}$ & \\
\hline FD-1 & $D-10$ & Hot leg, Spool 1 & & $\begin{array}{c}69,70,71 \\
69,71\end{array}$ & FT-1 failed during Test 1002 \\
\hline FT-1 & $\begin{array}{l}D-1 V \\
D-19 y\end{array}$ & & & $\begin{array}{l}69,71 \\
-7,73 \cdot 74\end{array}$ & \\
\hline $\begin{array}{l}\text { FD }-19 \\
\text { FT- } 19\end{array}$ & $\begin{array}{l}D-19 V \\
D-19 v\end{array}$ & Pump discharge, Spool 19 & & $+7.73,74$ & FT-19 fptled during Tests 1001, 1002, and 1003 \\
\hline $\mathrm{FD}-22$ & $D-22 \mathrm{~V}$ & Cold leg, Spool 22 & & $75,76,77$ & \\
\hline FT-22 & $D-22 \mathrm{~V}$ & Cold leg, Spool 22 & & $75,76,77$ & \\
\hline FD-5 & $D-5 v$ & Hot leg, Spool 5 & & $78,79,80$ & \\
\hline FD-15 & $D-15 \mathrm{~V}$ & Pump suction, Spool 15 & & $78,79,80$ & \\
\hline Blowdown & Loop & & 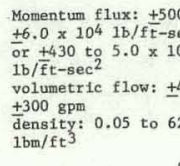 & $\begin{array}{l}00 \text { to } \\
\sec ^{2} \\
10^{4} \\
+40 \\
62.4\end{array}$ & \\
\hline FD-70 & D-70v. & Hot leg, Spool 70 & & $81,82,83$ & \\
\hline FT -70 & D-70v & & & 81,82 & FT-70 failed during Test 1003 \\
\hline FD-50 & D-50v & Cold leg, Spool 50 & & $84,85,86$ & \\
\hline IDD-76 & $\mathrm{D}-76 \mathrm{v}$ & Cold leg, Spool 76 & & $84,85,86$ & \\
\hline Core Barr & el Inlet & & 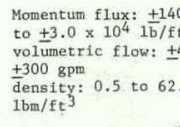 & $\begin{array}{l}40 \\
\mathrm{ft}-\mathrm{sec}^{2} \\
\pm 40 \text { to } \\
2.4\end{array}$ & (.) \\
\hline $\mathrm{FD}-224$ & D-225H & $\begin{array}{l}\text { D-225H: } 110.0 \text { inches, } 0^{\circ} \\
\text { FD-224: } 110.0 \text { inches, } 315^{\circ}\end{array}$ & & $87,88,89$ & FT-C-1 falled during Test 1002 \\
\hline $\mathrm{FT}-\mathrm{C}-1$ & D-225H & FT-C-1: 110.0 inches & & 87,89 & \\
\hline DENSITY, FL & & & $\begin{array}{l}0.05 \text { to } 62.4 \mathrm{bm} / \\
\mathrm{ft}^{3}\end{array}$ & & $\begin{array}{l}\text { Obtained by ganma attenuation technique } \\
\text { (densitometer). }\end{array}$ \\
\hline Operating & Loop & & & & \\
\hline D-1V & & Hot $1 \mathrm{eg}$, Spool 1 & & $90,91,92$ & \\
\hline D-5V & & Hot log, Epoul 5 & & $90,91,92$ & \\
\hline $\mathrm{D}-15 \mathrm{~V}$. & & Puinp suction, Spool 15 & & $93,94,95$ & \\
\hline D-19V & & Pump discharge, Spool 19 & & $93,94,95$ & \\
\hline $\begin{array}{l}D-22 \mathrm{H} \\
D-22 \mathrm{~V}\end{array}$ & & Cold leg, Spool 22 & & $\begin{array}{c}96 \\
96,97,98\end{array}$ & $\begin{array}{l}\text { D-22H falled during Test 1002, and was not } \\
\text { used during Test } 1003\end{array}$ \\
\hline
\end{tabular}




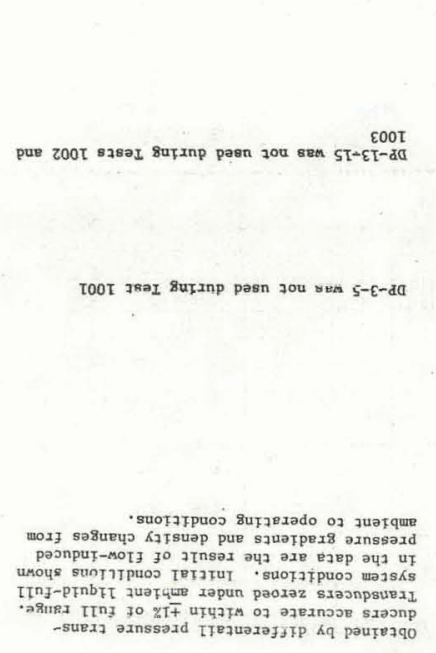

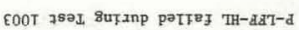

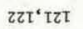

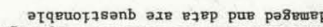

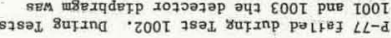

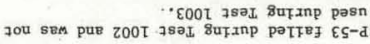

ZET
IEI
OET

(1)

LZT

9ZI

sZI

$\pitchfork z \tau$

$\varepsilon \succsim \tau$
pFsd $0.05 \bar{t}$

\section{PFsd $9 \cdot E \bar{E}$}

pFsd $8.82 \overline{+}$

ptrsd 0.05T

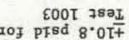

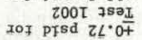

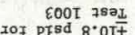

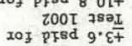

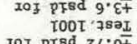

prsd $z L^{\circ}$

8rsd $0.05 \bar{t}$

3rsd $06 z-0$ $8 \mathrm{Fsd} 00 \mathrm{~T}-0$

$8 \mathrm{Tsd} 00 \mathrm{z}-0$

8fsd 00I-0

8 Fsd $000 T-0$

$O Z T-L T T$

$9 \tau \tau-\eta I \tau$

8รsd $000 \varepsilon-0$

$\varepsilon \mathrm{II}-\mathrm{III}$

8F8d 000£-0

8รsd $000 \varepsilon-0$

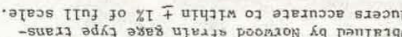

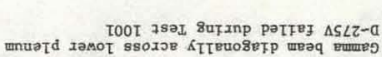

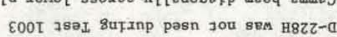

LOT - SOT

$70 \tau-$ zOT

TOT - 66

$[\mathrm{p}]^{\text {वाn } 8 F A}$

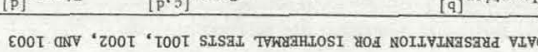

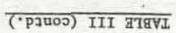

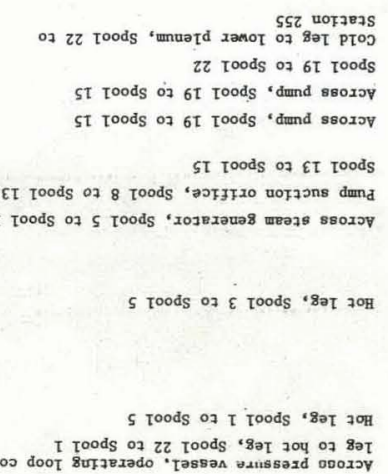

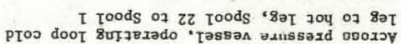

$\tau-z z-d d$ d०ण अurjesedo

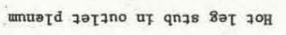

$s s z-z z-d a$

$z z-6 \mathrm{t}-\mathrm{da}$

TST-6I- $\mathrm{da}$

$\varepsilon T-8-9$

$\varepsilon \tau-\varsigma-ð C$

$s-\varepsilon-d a$

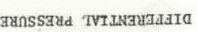

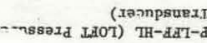

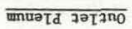

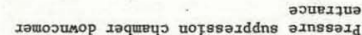

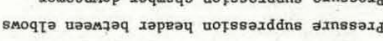

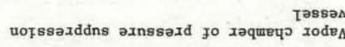

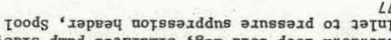

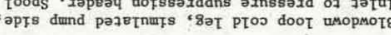

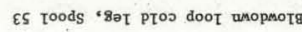

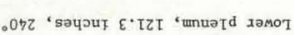

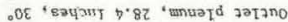

26 toods : Bet ptos $0 L$ Ioods '8at 7он 29 toods 'Kataej

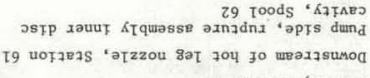

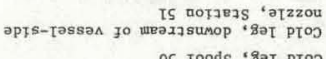
OS toods "BaI PIOJ ‘

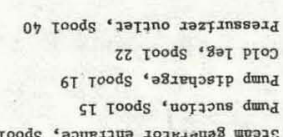

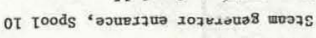
โ Toods '80T 70H

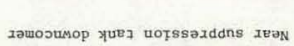

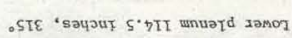
.0 'sayjut $7 \cdot z Z I$ unuatd xamo

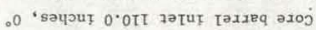

24 Loods "82t pToj 06 toods i 827 70H os roods '8ak pios

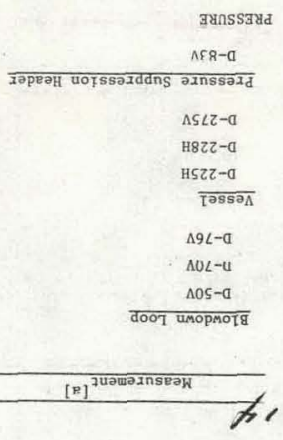

ctil h 


\section{TABLE III (contd.)}

DATA PRESENTA'IION FOR ISOTHERMAL TESTS 1001, 1002, AND 1003

TABLE III (contd.)

DATA PKESENTATION FOR ISOTHERMAL TESTS 1001, 1002, AND 1003

\begin{tabular}{|c|c|c|c|c|}
\hline Measurement $^{[\mathrm{a}]}$ & Location ${ }^{[b]}$ & Range $^{[c, d]}$ & Figure ${ }^{[\mathrm{d}]}$ & Comment ${ }^{[\mathrm{d}]}$ \\
\hline \multicolumn{5}{|l|}{ Vesse1 } \\
\hline DP-255-207 & $\begin{array}{l}\text { Vessel lower plenum to vessel upper plenum, } \\
\text { Station } 255 \text { to Station } 207\end{array}$ & $\begin{array}{l}+50.0 \text { psid for } \\
\text { Tests } 1001 \text { and } \\
1002 \text {. } \\
+10.8 \text { psid for } \\
\text { Test } 1003\end{array}$ & 133 & DP-255-207 failed during Test $100 \hat{\jmath}^{\circ}{ }^{\circ}$ \\
\hline \multicolumn{5}{|l|}{ Downcomer } \\
\hline DP-213-246 & Station 213 to Station 246 & \pm 1.8 psid & 134 & \\
\hline DP- $246-249$ & Station 246 to Station 249 & \pm 1.8 psid & 135 & \\
\hline DP $-249-255$ & Station 249 to Station 255 & \pm 0.72 psid & 136 & \\
\hline \multicolumn{5}{|l|}{ Lower P1enum } \\
\hline$D P-261-255$ & Station 261 to Station 255 & \pm 0.72 psid & 137 & \\
\hline \multicolumn{5}{|c|}{ 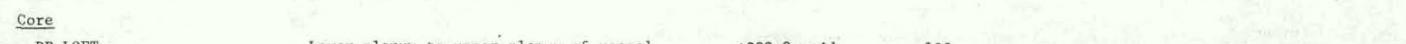 } \\
\hline DP-LOFT & Lower plenum to upper plenum of vessel & \pm 200.0 psid & 138 & \\
\hline \multicolumn{5}{|l|}{ Blowdown Loop } \\
\hline$D P-207-70$ & $\begin{array}{l}\text { Vessel upper plenum to blowdown hot leg, } \\
\text { Station } 207 \text { to. Spool } 70\end{array}$ & $\begin{array}{l}+3.6 \text { psid for } \\
\text { Tests } 1001 \text { and } \\
1002 \\
+100.0 \mathrm{psid} \text { for } \\
\text { Test } 1003\end{array}$ & 139 & DP-207-70 falled during Test 1003 \\
\hline DP-264-50 & $\begin{array}{l}\text { Vesse1 Inlet annulus to blowdown 10op } \\
\text { cold leg, Station } 264 \text { to Spool } 50\end{array}$ & $\pm 100.0 \mathrm{psid}$ & 140 & \\
\hline DP $-52-62$ & Across rupture discs, Spool 52 to Spool 62 & $\pm 500.0 \mathrm{ps} 1 \mathrm{~d}$ & & $\begin{array}{l}\text { DP-52-62 was not used during Tests } 1001 \text { and } \\
1002 \text { and failed during Tests } 1003\end{array}$ \\
\hline DP $-76-61$ & Across hot leg nozzle, Spool 76 to Station 61 & $\pm 500.0 \mathrm{psid}$ & 141 & \\
\hline $\mathrm{DP}-76-\mathrm{HN} 2$ & $\begin{array}{l}\text { Spool } 76 \text { to hot leg nozzle downstream throat } \\
\text { (Port 2) }\end{array}$ & $\pm 1500.0 \mathrm{psid}$ & 142 & $\begin{array}{l}\text { DP-76-HN2 data are presented with sign } \\
\text { reversed }\end{array}$ \\
\hline$D P-96-76$ & Across simulated pump, Spool 96 to Spool 76 & $\begin{array}{l} \pm 100.0 \text { psid for } \\
\text { Tests } 1001 \text { and } \\
1002.0 \text { psid for } \\
\pm 50.0 \text { psid } \\
\text { Test } 1003\end{array}$ & 143 & DP-96-76 failed during Test 1002 \\
\hline DP $-70-96$ & $\begin{array}{l}\text { Across simulated steam generator, Spool } 70 \\
\text { to Spool } 96\end{array}$ & \pm 50.0 psid & 144 & \\
\hline DP5-HN2-HN4 & $\begin{array}{l}\text { Vesse1 side, downstream nozzle throat (Port 2) } \\
\text { to downstream nozzle expansion section (Port 4) }\end{array}$ & $\pm 1000.0 \mathrm{psid}$ & $14 j^{\prime}$ & \\
\hline DP6-HN2-HN4 & $\begin{array}{l}\text { Simulated pump side, downstream nozzle throat } \\
\text { (Port 2) to downstream nozzle expansion } \\
\text { section (Port 4) }\end{array}$ & $\begin{array}{l} \pm 1000.0 \text { psid } \\
\pm 200.0 \text { psid for } \\
\text { Test } 1003\end{array}$ & 146 & $\begin{array}{l}\text { DP6-HN2-HN4 signal conditioning system sat- } \\
\text { urated for the first } 14 \text { sec during Test } 1003 \text {. } \\
\text { The magnitude of data above } 200 \text { psid is } \\
\text { questlonable for Test } 1003 \text {. }\end{array}$ \\
\hline Pressure Suppression System & $\begin{array}{l}\text { Across hot leg nozzle outlet, downstream } \\
\text { nozzle expansion section (Port } 4 \text { ) to } \\
\text { Station } 61\end{array}$ & $\begin{array}{l}\frac{+18.0 \text { psid for }}{\text { Tests } 1001 \text { and }} \\
1002 \\
\frac{+200.0 \text { psid for }}{\text { Test } 1003}\end{array}$ & 147 & $\begin{array}{l}\text { DP-HN4-61 signal conditioning system sat- } \\
\text { urated for the first } 16 \text { sec during Test } 1001 \\
\text { and during the period between } 13 \text { and } 17 \mathrm{sec} \\
\text { during Test } 1002 \text {. Deta beyond the range } \\
\text { limits are questionable }\end{array}$ \\
\hline$\frac{\text { Pressure Suppression System }}{\text { DP-207-89 }}$ & $\begin{array}{l}\text { Vessel upper plenum to vapor chamber of } \\
\text { pressure suppression tank }\end{array}$ & \pm 500.0 psid & 248 & \\
\hline DP $-81-83$ & Header to downcomer entrance & $\begin{array}{l}+10.8 \text { psid for } \\
\frac{T}{T e s t s} 1001 \text { and } \\
1002 \\
+18.0 \text { psid for } \\
\text { Test } 1003\end{array}$ & 149 & \\
\hline DP- $83-85$ & Downcomer entrance to downcomer exit & \pm 10.8 psid & 150 & \\
\hline DP $-83-89$ & $\begin{array}{l}\text { Douncomer entrance to vapor chamber of } \\
\text { pressure suppression tank }\end{array}$ & \pm 50.0 psid & 151 & \\
\hline DP- $85-89$ & $\begin{array}{l}\text { Downcomer exit to vapor chamber of } \\
\text { pressure suppression tank }\end{array}$ & \pm 18.0 psid & 152 & DP-85-89 was not used during Test 1001 \\
\hline LXQUID LEVEL & & & & $\begin{array}{l}\text { Liquid level in lower plenum is indicated } \\
\text { by density measurements } D-228 H \text { and } D-275 V \\
\text { and by differential pressure measurement } \\
\text { DP-261-255 }\end{array}$ \\
\hline$\frac{\text { Lower P1enum }}{\text { LL-LFTA-259 }}$ & \multicolumn{4}{|c|}{ LL-LFTA-259 } \\
\hline LL-LFTD-259 & & & & \\
\hline \multicolumn{5}{|l|}{$\begin{array}{l}\text { LL-LFTD-259 } \\
\text { Pressure Suppression System }\end{array}$} \\
\hline LL-PSS & Suppression tank & 3.64 psid & & $\begin{array}{l}\text { obtained by differential pressure cell having } \\
\text { one leg connected to a standpipe and the } \\
\text { other leg attached to a port in the bottom } \\
\text { of the pressure suppression tank. LL-PSS } \\
\text { falled during Tests } 1002 \text { and } 1003\end{array}$ \\
\hline PUMP CHARACTERISTICS & Operating loop pump & & & \\
\hline \multicolumn{5}{|l|}{ Pump Speed } \\
\hline PS-RPM & & - & \multicolumn{2}{|c|}{$154-156$} \\
\hline \multicolumn{5}{|l|}{ Pump Power } \\
\hline \multicolumn{5}{|l|}{ Pump Torque } \\
\hline T-PMP & & - & $160-1$ & \\
\hline
\end{tabular}


TABLE III (contd.)

DATA PRESENTATION FOR ISOTHERMAL TESTS 1001, 1002, AND 1003

IABLB III (contd.)

DATA PRESENTATION FOR ISOTHRRMAL TESTS 1001, 1002, AND 1003

\begin{tabular}{|c|c|c|c|}
\hline Measurcment ${ }^{[a]}$ & Location $^{[\mathrm{b}]}$ & Figure $^{[\mathrm{d}]}$ & Comment $^{[\mathrm{d}]}$ \\
\hline TIME OF BREAK & & & $\begin{array}{l}\text { Data not presented; measurement established } \\
\text { time of rupture as indicated by } t=0 \text { seconds } \\
\text { on all data plots }\end{array}$ \\
\hline \multicolumn{4}{|l|}{ Blowdown Loop } \\
\hline BW-52 & Cold leg, vessel side & & \\
\hline BW-62 & Culd leg, simulated pump side & & \\
\hline nTSPIAGEYENT & & & $\begin{array}{l}\text { System not calibrated, data useful only for } \\
\text { relative motion indication. }\end{array}$ \\
\hline Pressure Suppression System & & $163-16^{5}$ & \\
\hline LDT-PSH & Header first elbow (horizontal deflection) & & \\
\hline LDT-PSV & $\begin{array}{l}\text { Beneath suppression vessel (vessel vertical } \\
\text { deflection) }\end{array}$ & & \\
\hline \multicolumn{4}{|c|}{ [a] Measurement nomenclature is defined in Reference 1.} \\
\hline \multicolumn{4}{|c|}{ [b] Heasurement locations are shown in Figures 1 through 4 . } \\
\hline \multicolumn{4}{|c|}{ [c] The range indicated is that over which the measurement is considered valid. } \\
\hline \multicolumn{4}{|c|}{$\begin{array}{l}\text { Id] Ranges, figure numbers, and comments apply to all measurements within a category unless indicated otherwise. } \\
\text { The figure numbers correspond to the data plots presented. In general, where three figures are indicated the first } \\
\text { applies to Test } 1001 \text {, the second to Test } 1002 \text {, and the third to Test } 1003 \text {. }\end{array}$} \\
\hline
\end{tabular}




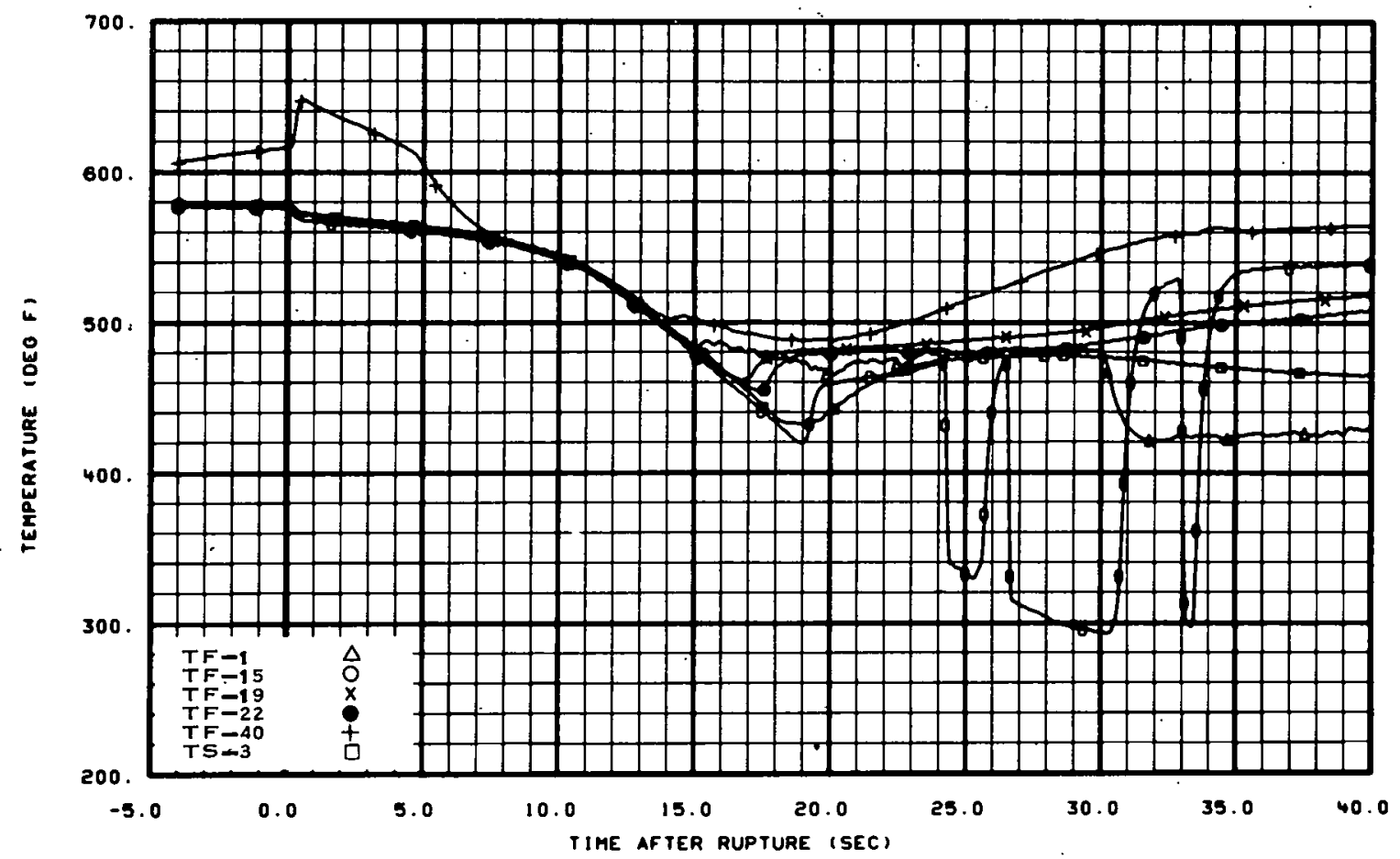

Fig. 5 Fluid temperatures in operating loop -- Test 1001.

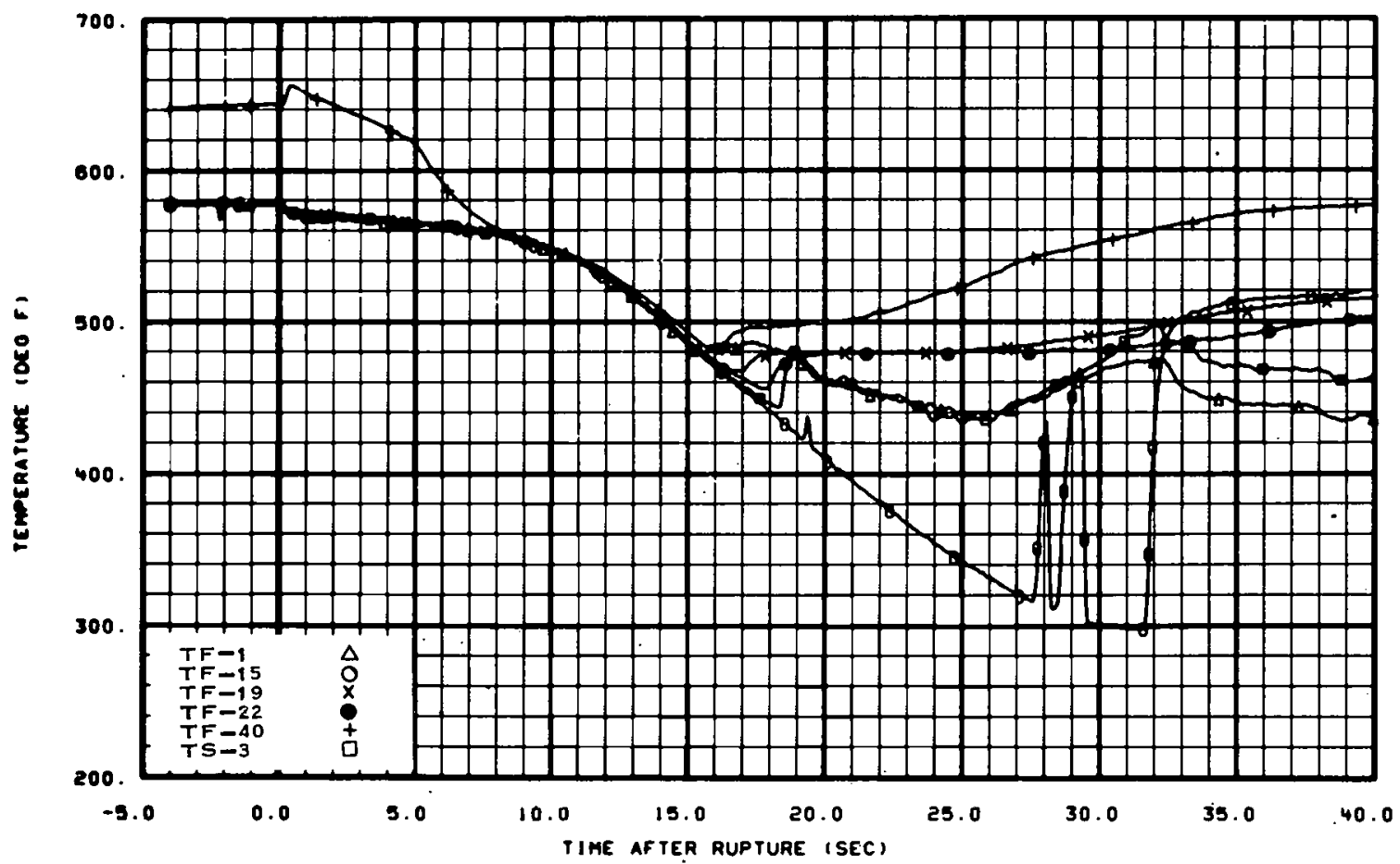

Fig. 6 Fluid temperatures in operating loop -- Test 1002. 


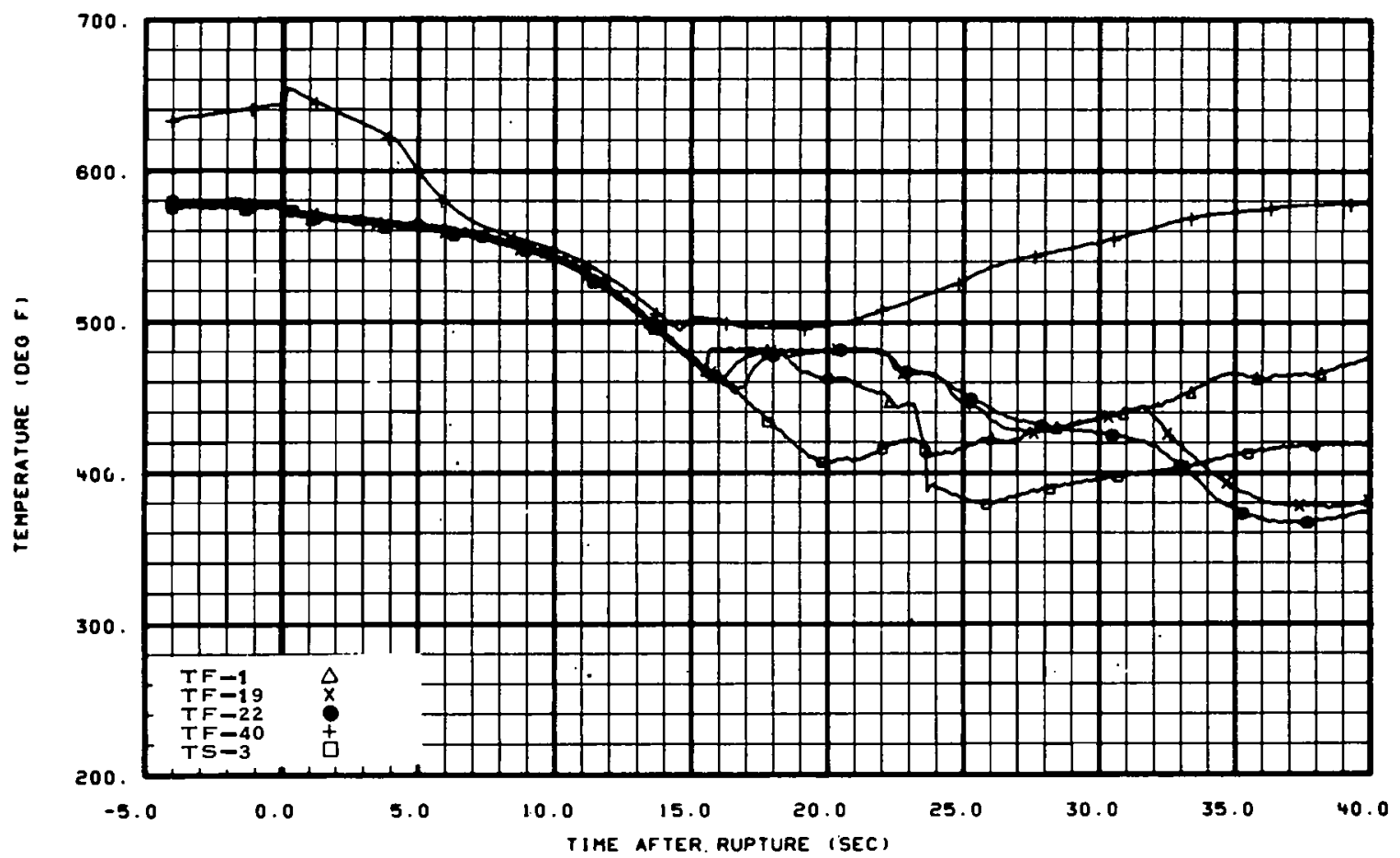

Fig. 7 Fluid temperatures in operating loop -- Test 1003.

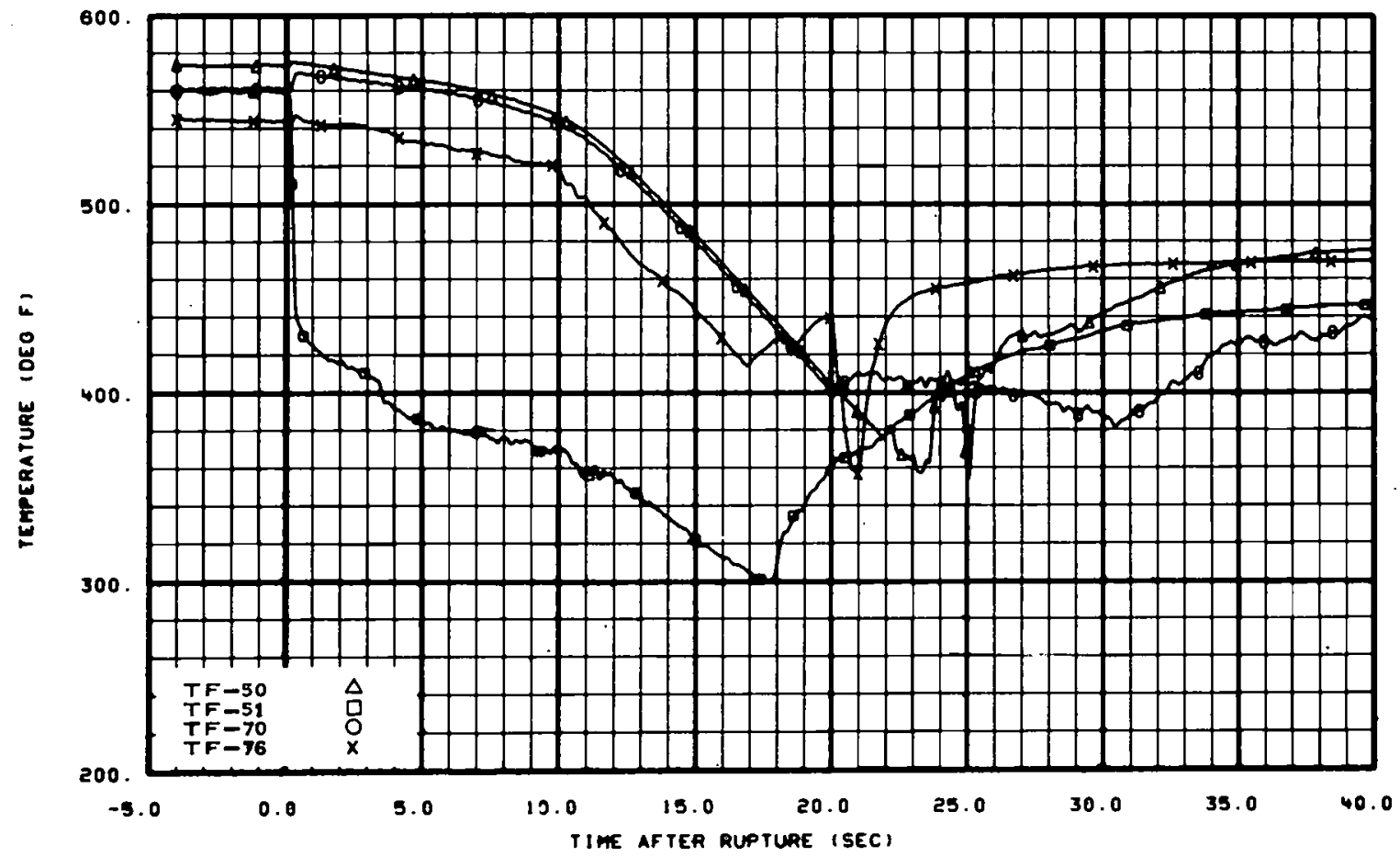

Fig. 8 Fluid temperatures in blowdown loop -- Test ' 1001. 


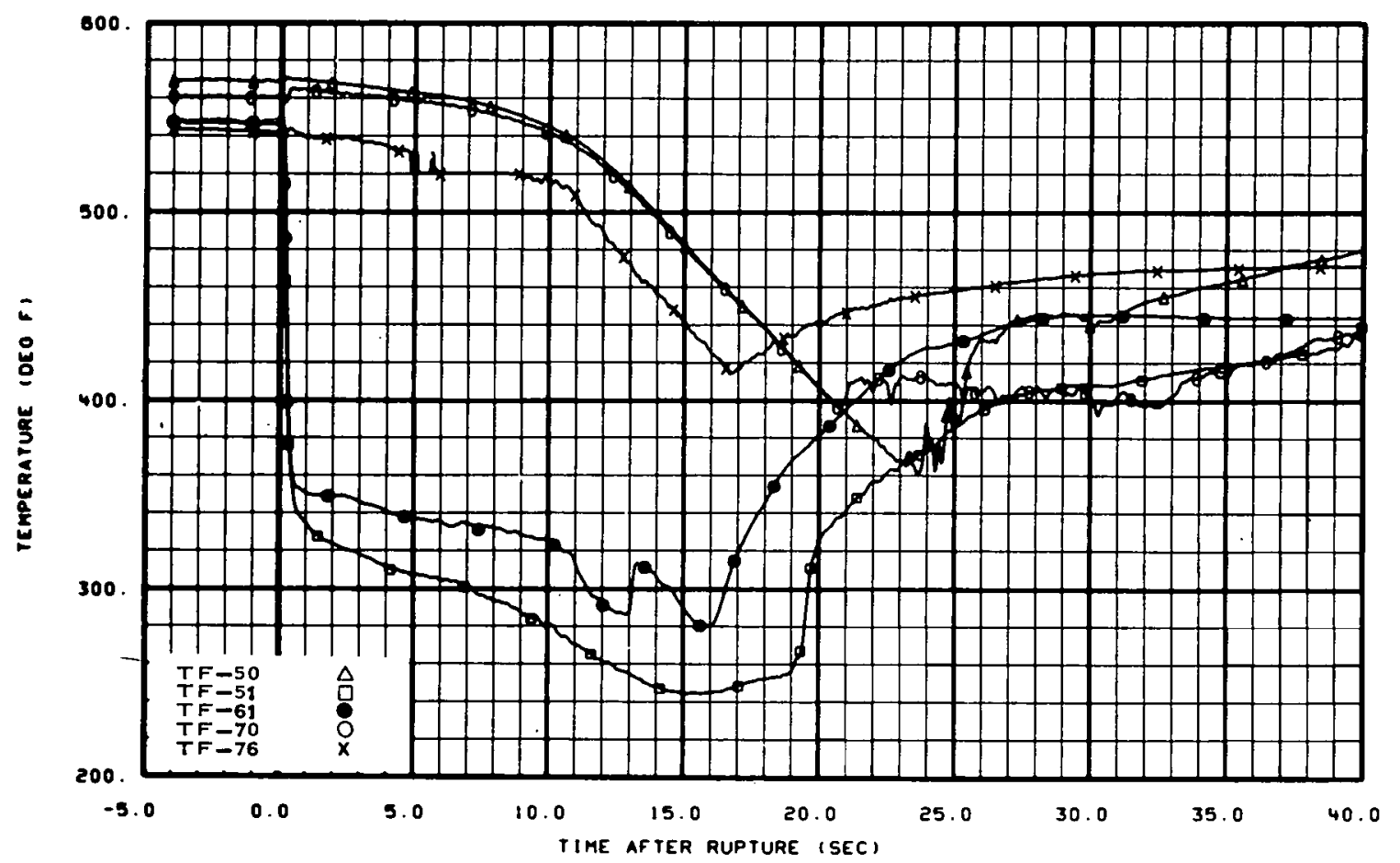

Fig. 9 Fluid temperatures in blowdown loop -- Test 1002.

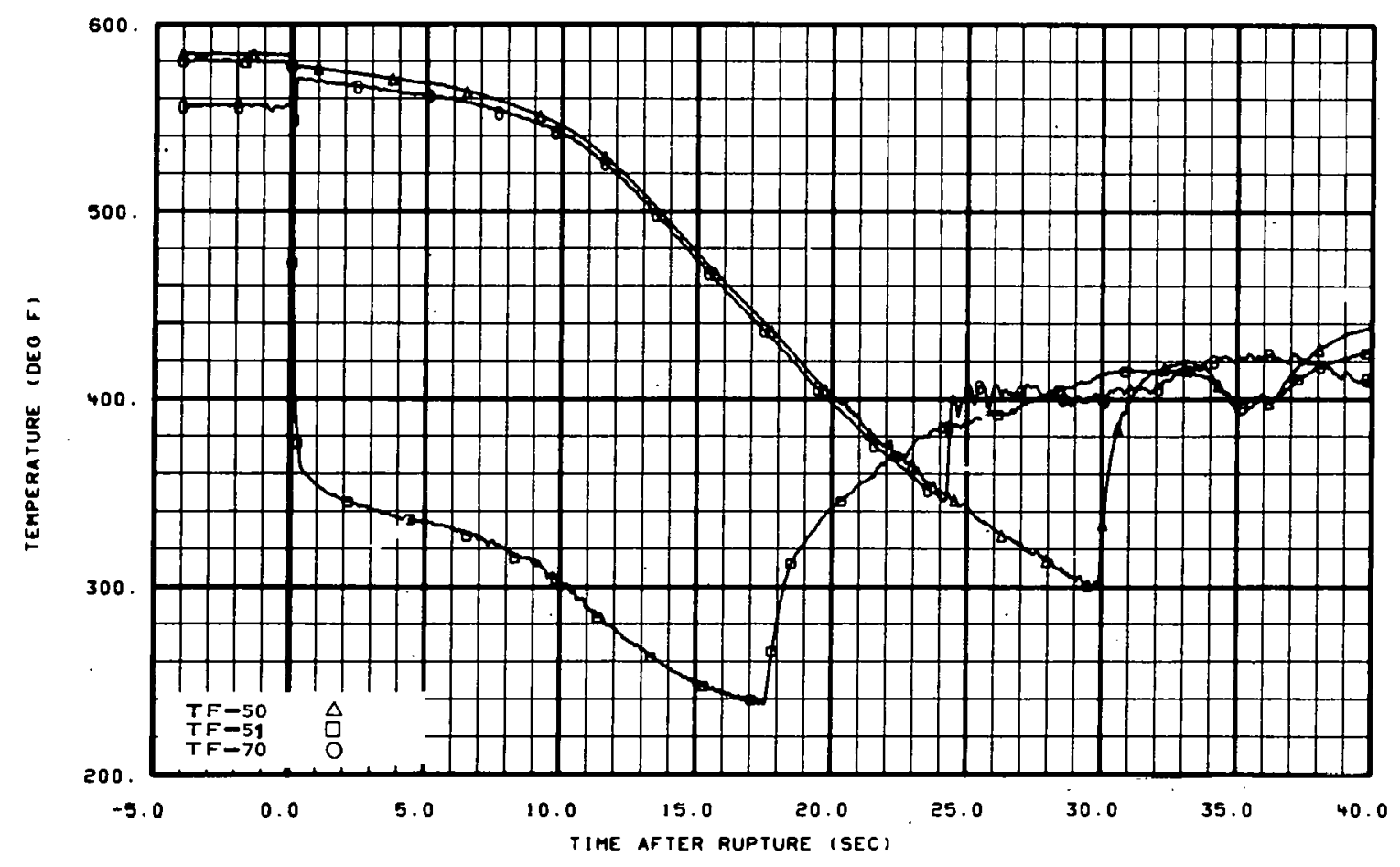

Fig. 10 Fluid temperatures in blowdown loop -- Test 1003. 


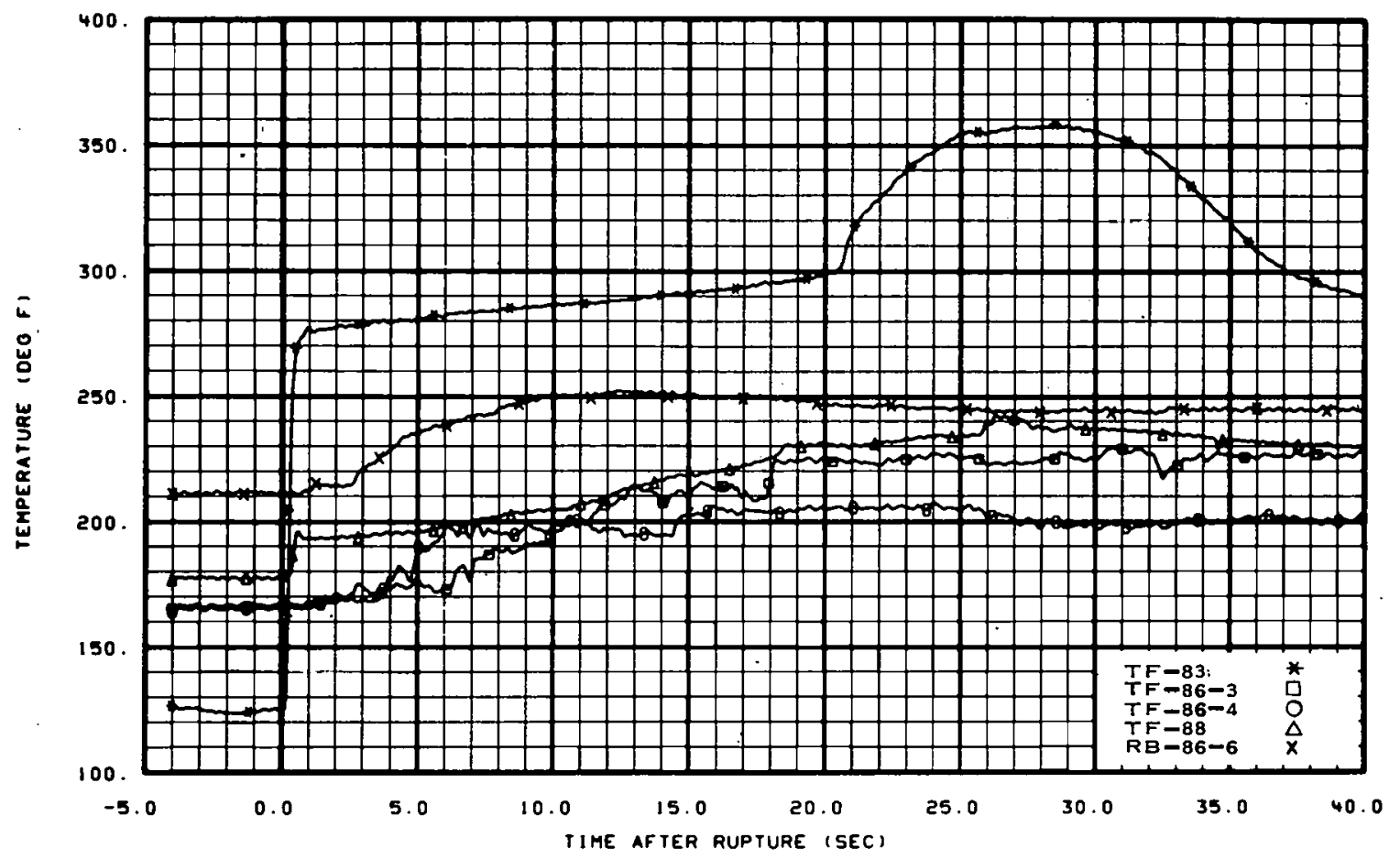

Fig. 11 Fluid temperatures in pressure suppression system - Test 1001.

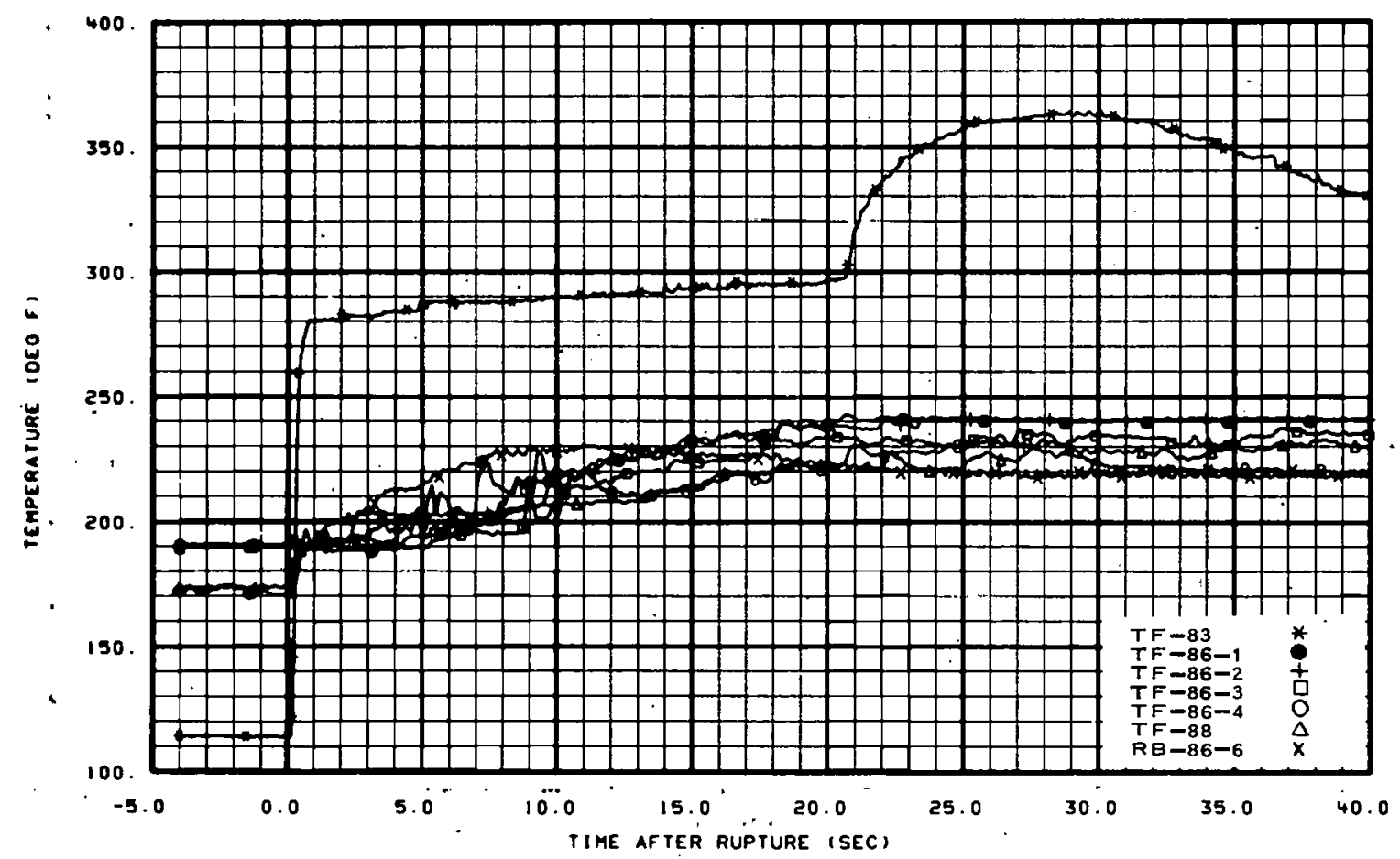

Fig. 12 Fluid temperatures in pressure suppression system - - Test 1002 . 


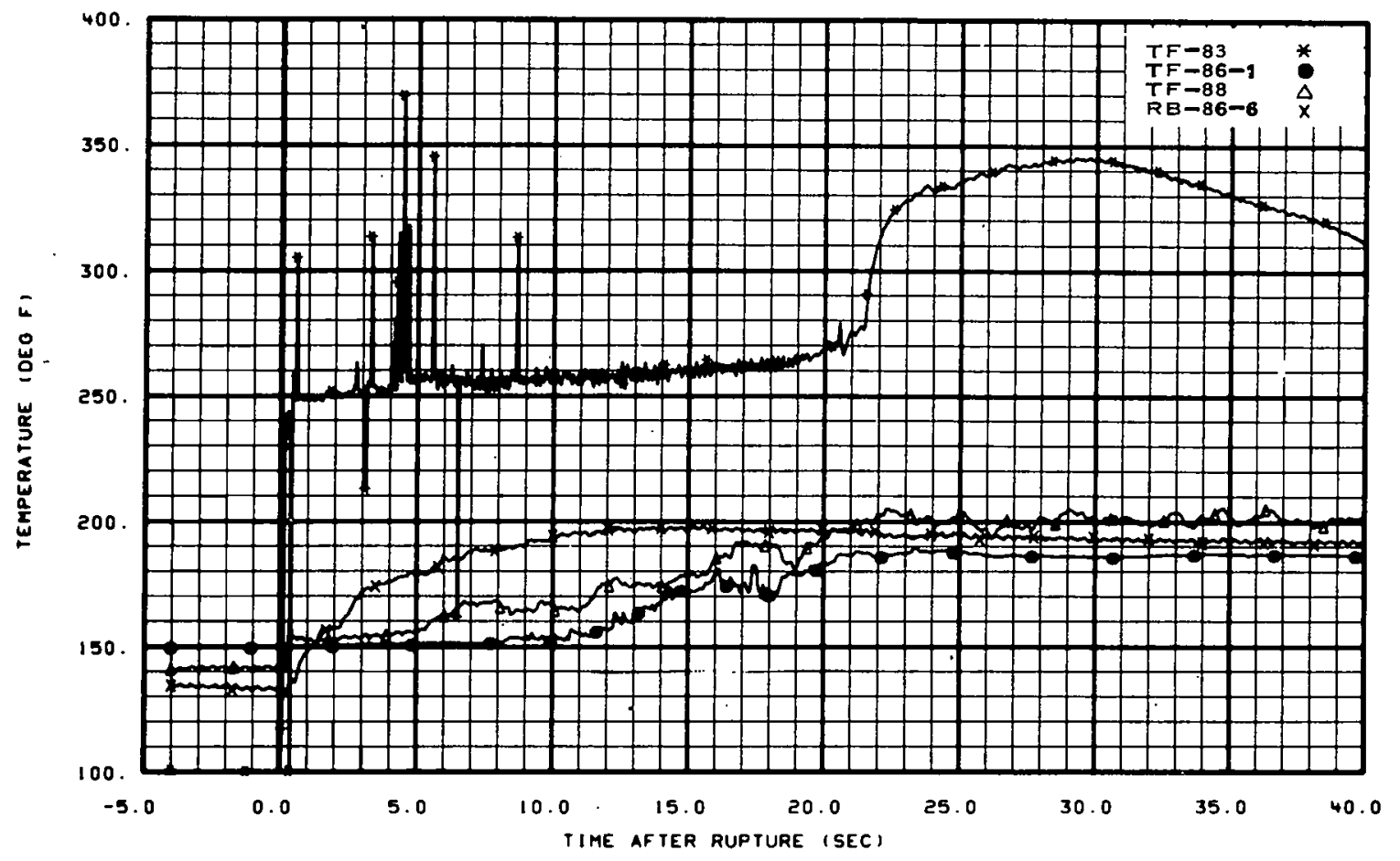

Fig. 13 Fluid temperatures in pressure suppression system -- Test 1003.

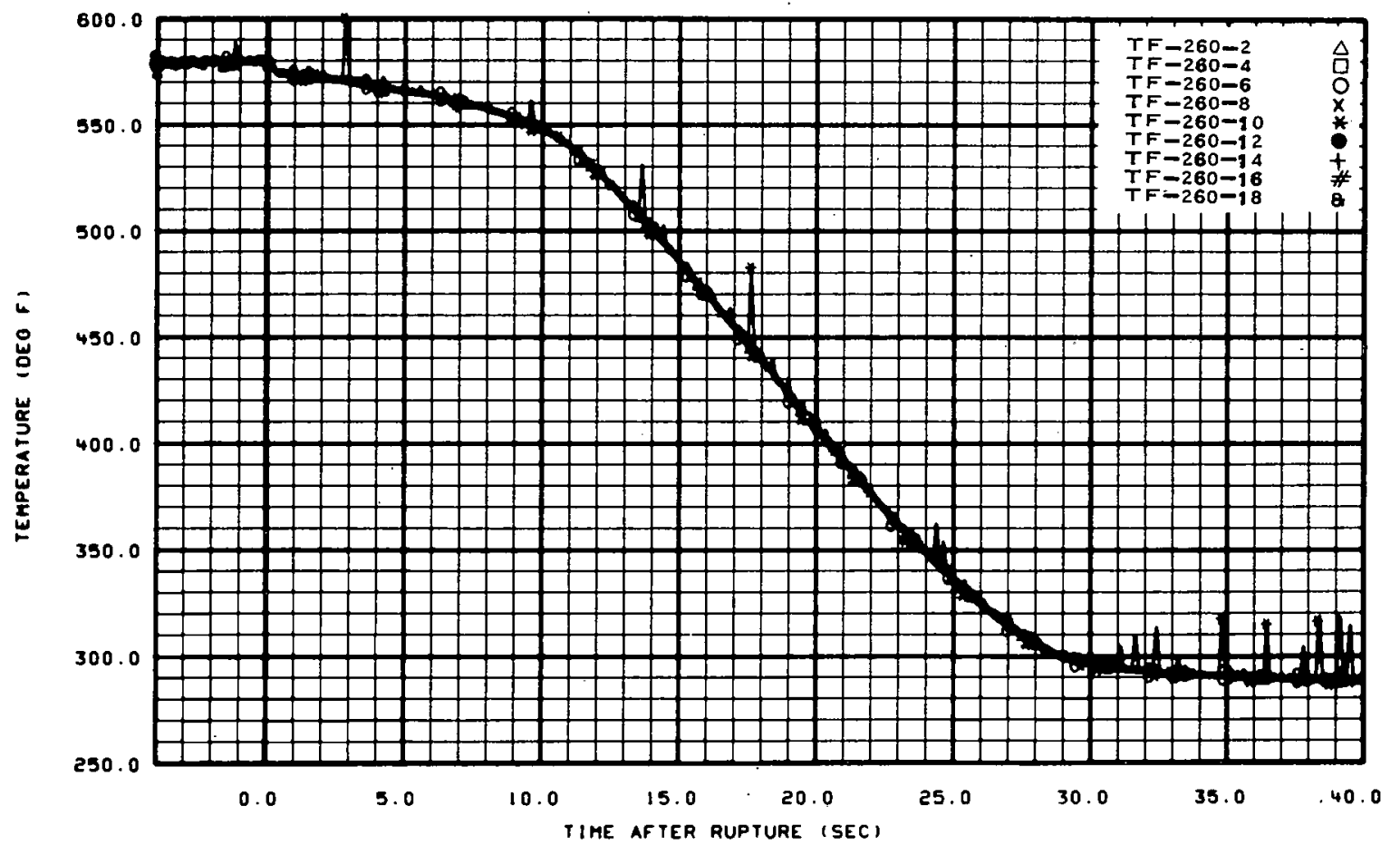

Fig. 14 Fluid temperatures in lower plenum at thermocouple rack -- Test 1001. 


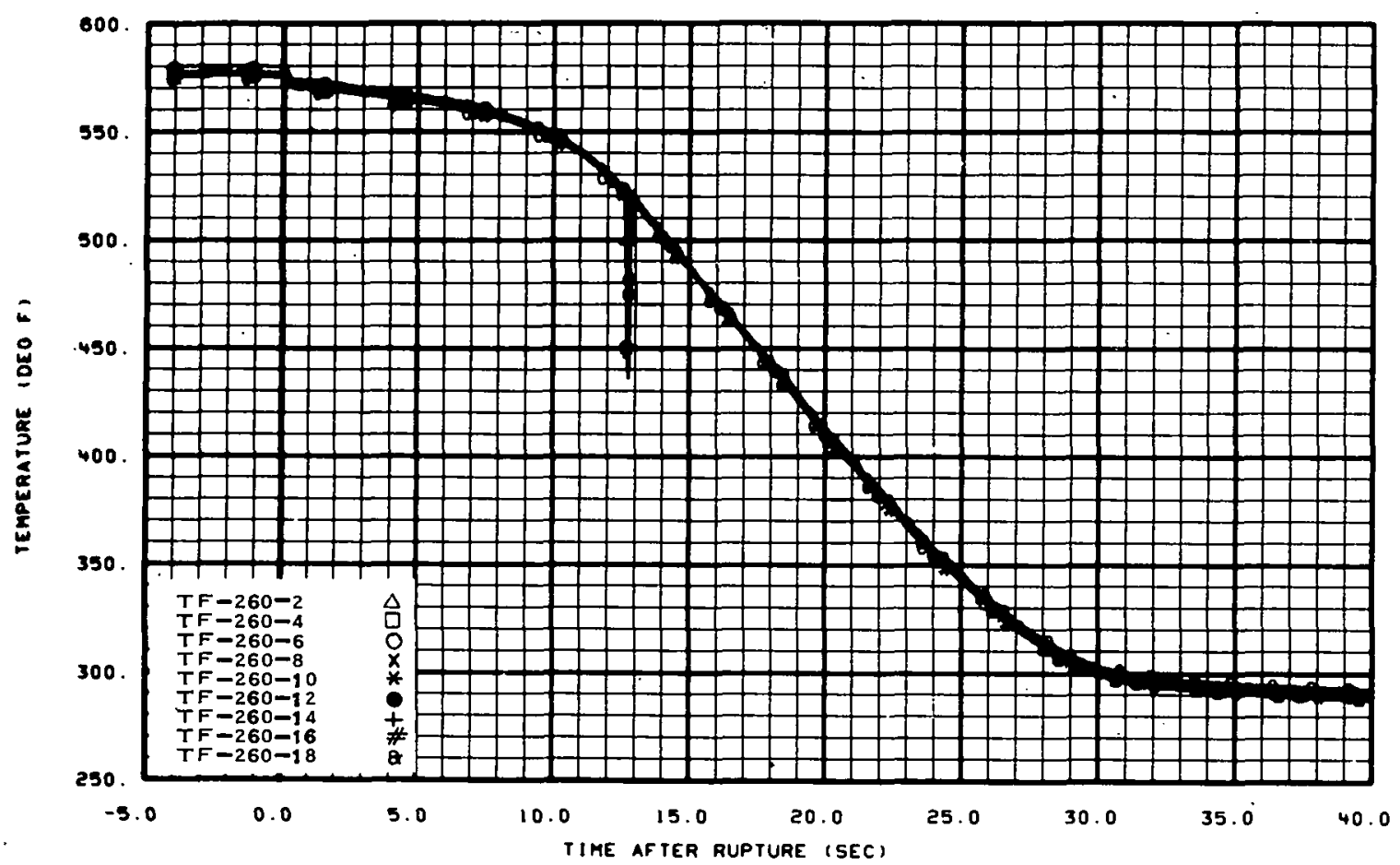

Fig. 15 Fluid temperatures in lower plenum at thermocouple rack -- Test 1002.

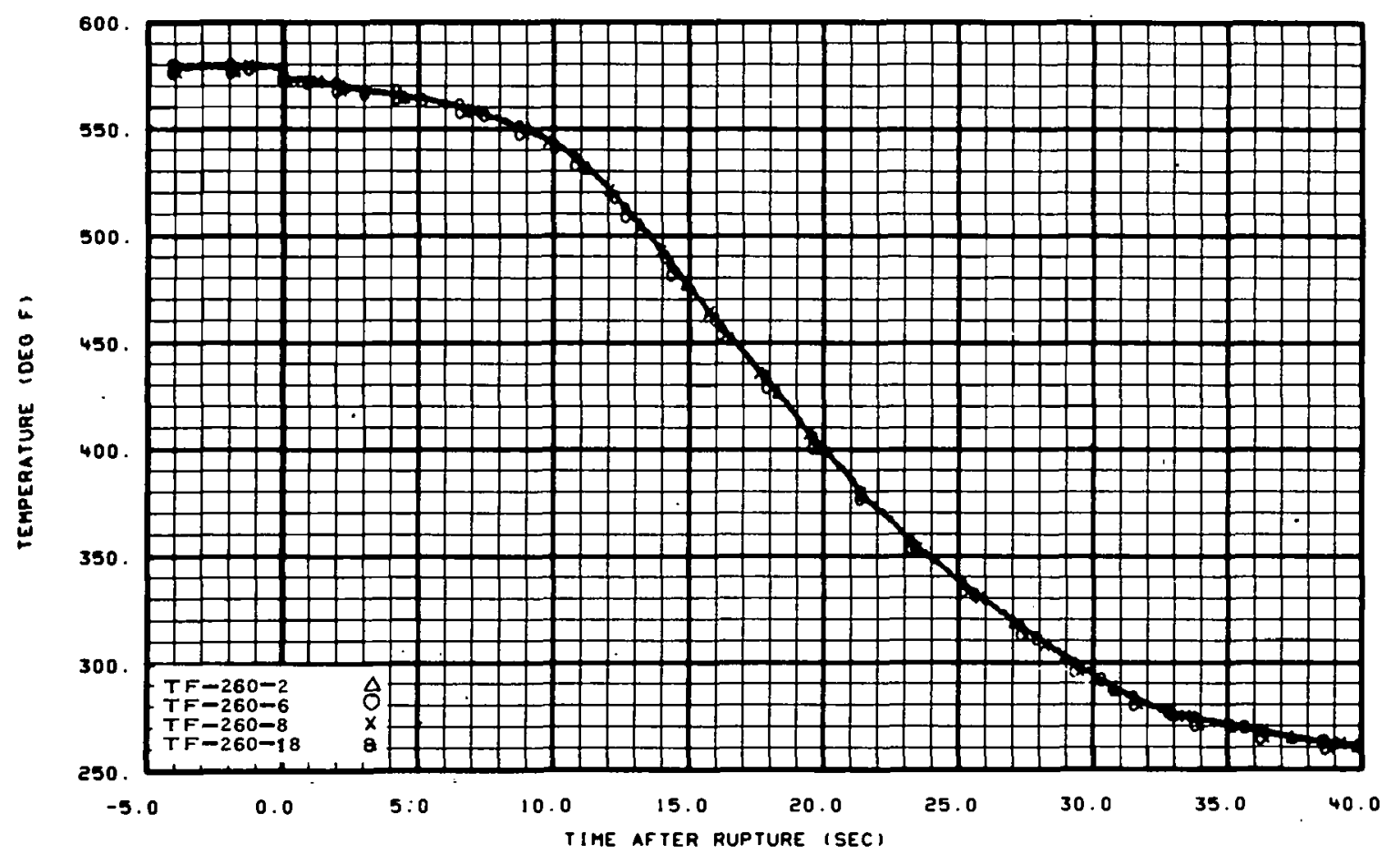

Fig. 16 Fluid temperatures in lower plenum at thermocouple rack -- Test 1003. 


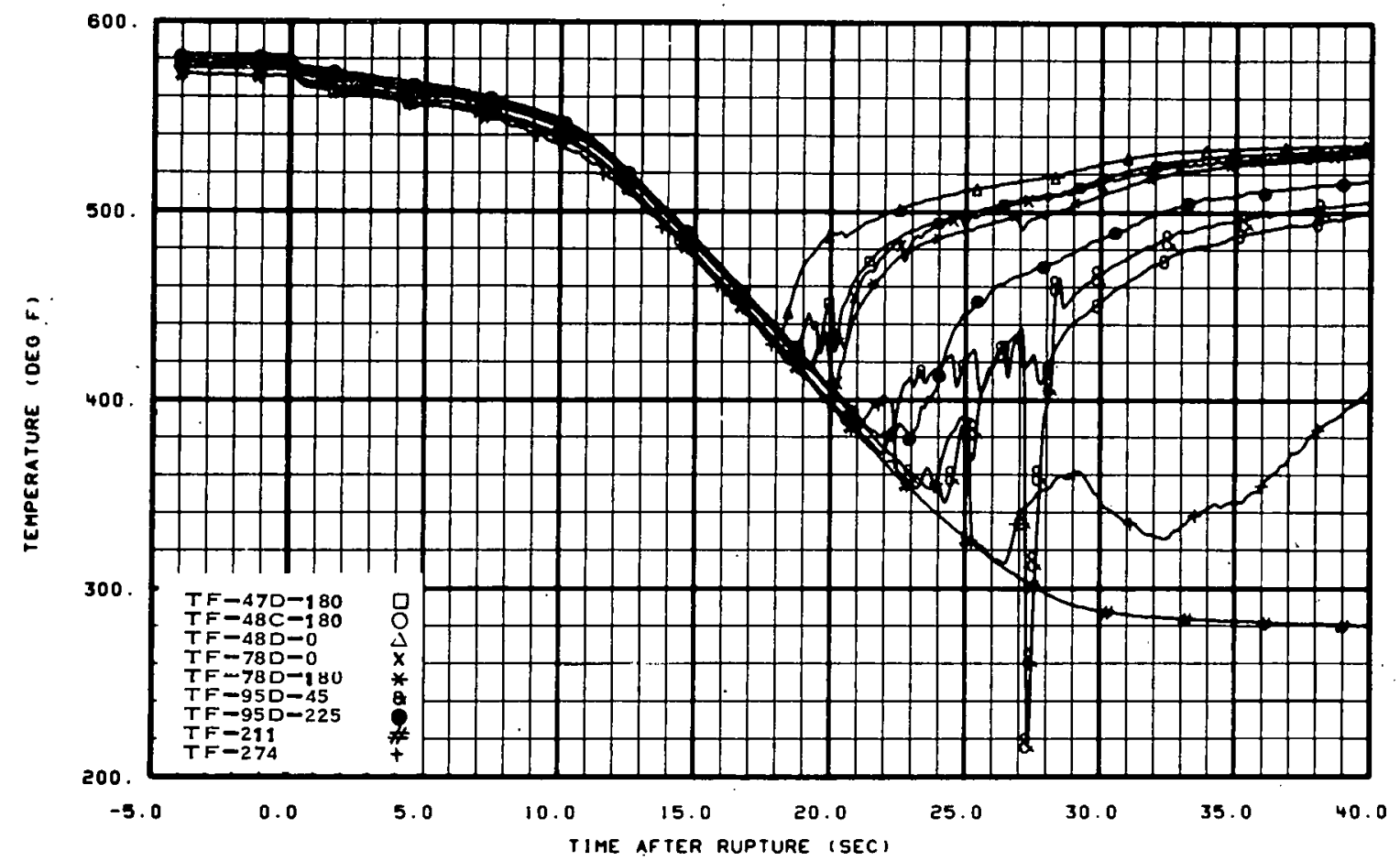

Fig. 17 Fluid temperatures in downcomer gap and outlet plenum -- Test 1001.

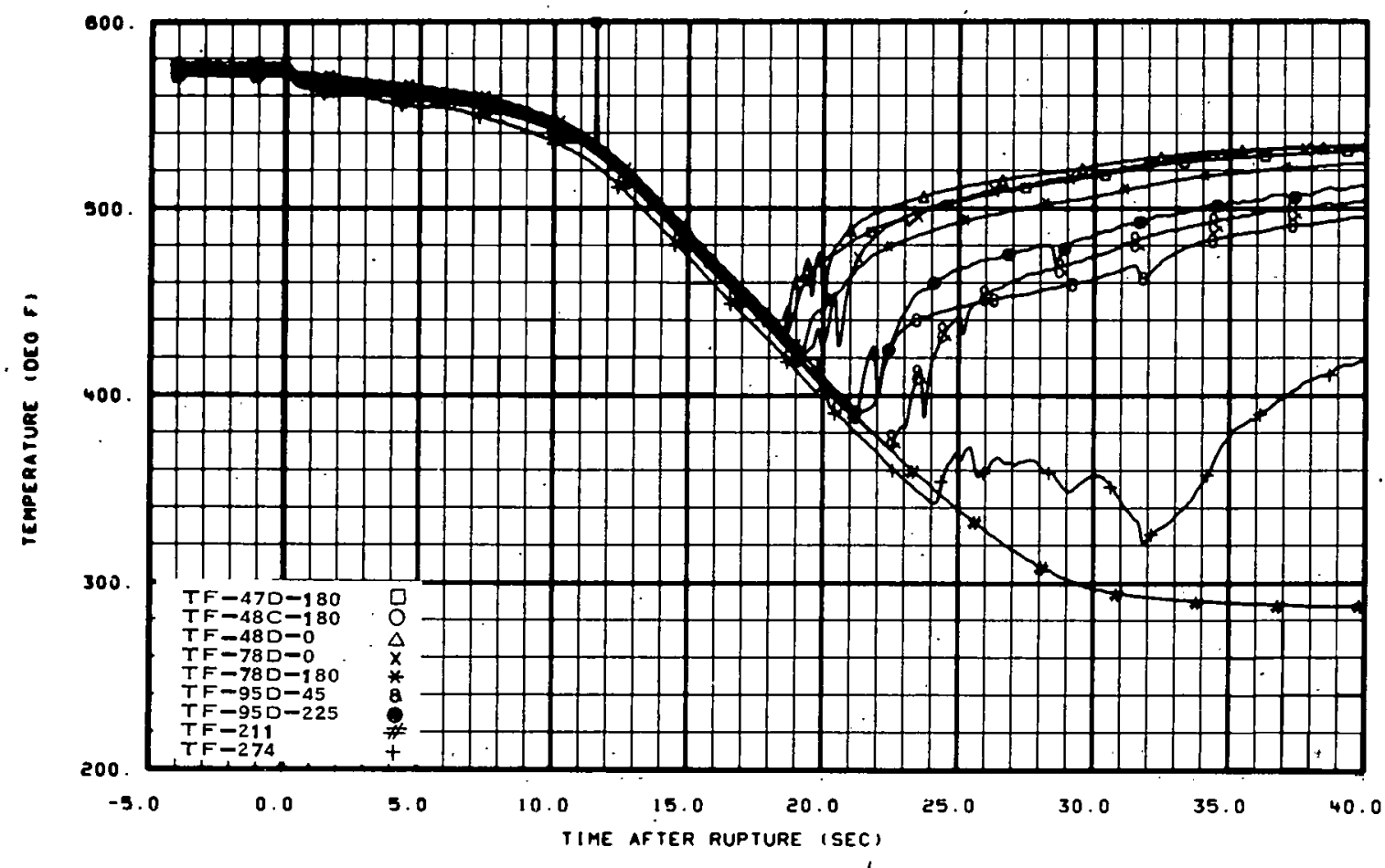

Fig. 18 Fluid temperatures in downcomer gap and outlet plenum -- Test 1002. 


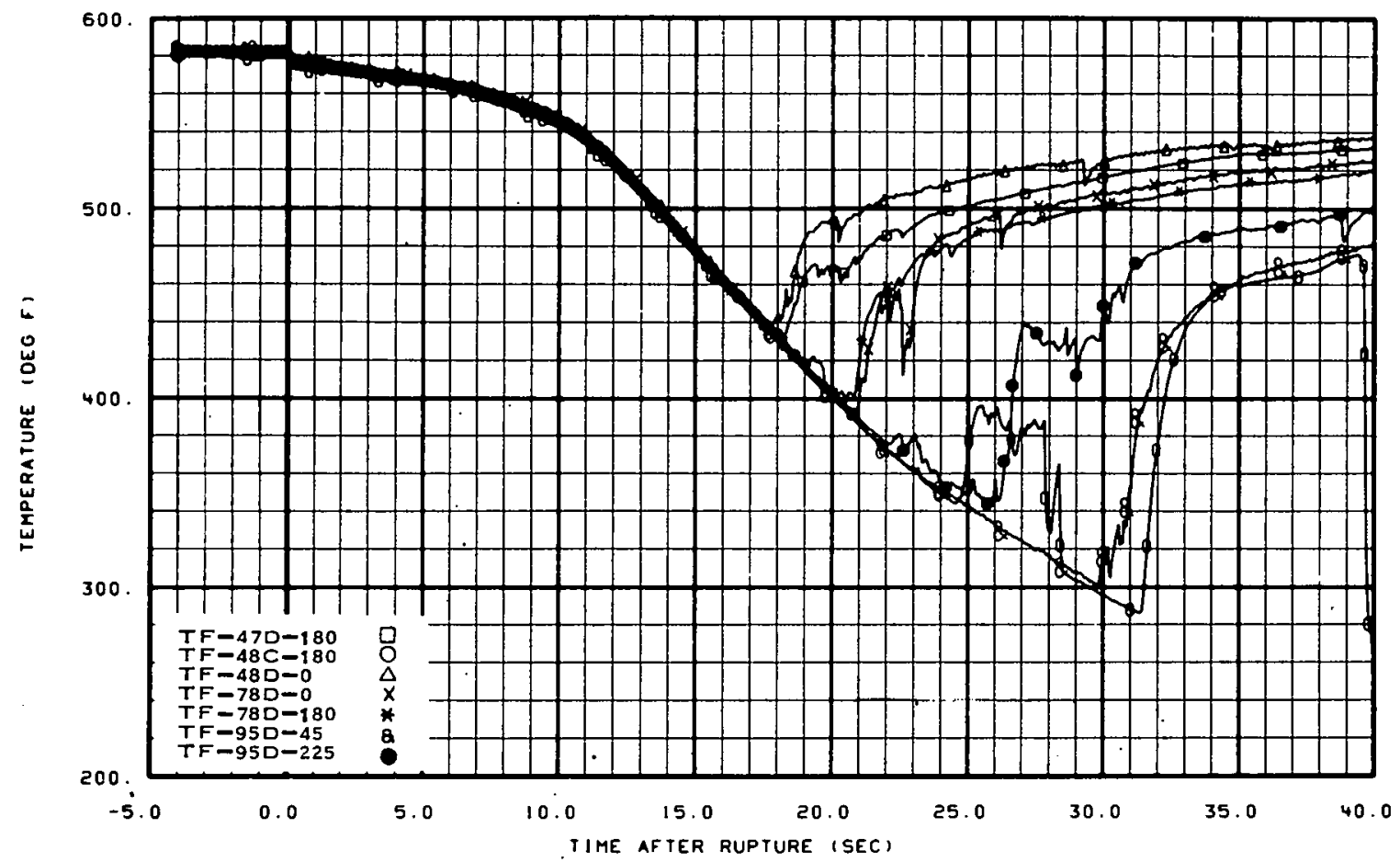

Fig. 19 Fluid temperatures in downcomer gap -- Test 1003.

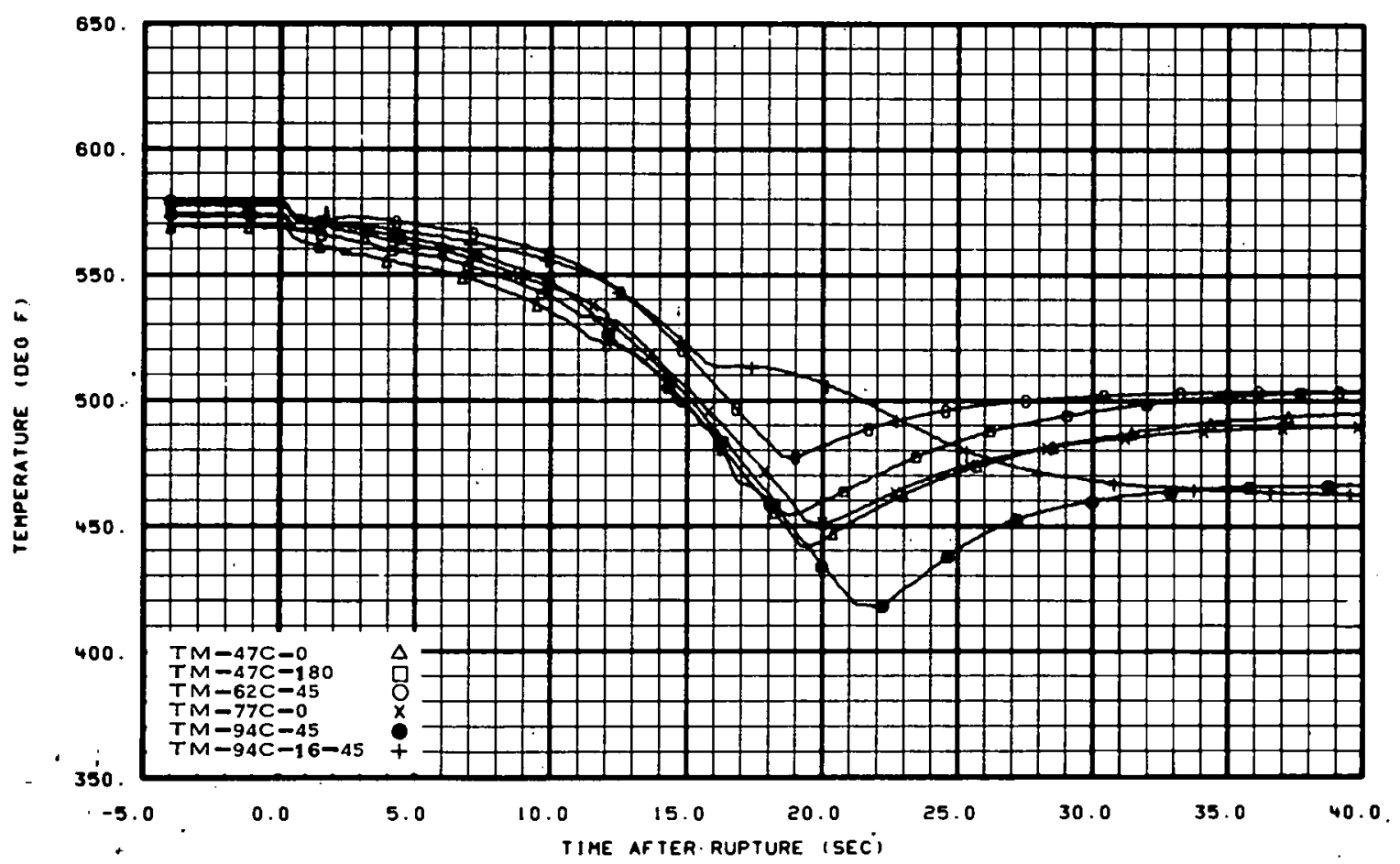

Fig. 20 Métal témperatures in core barrel -- Test 1001. 


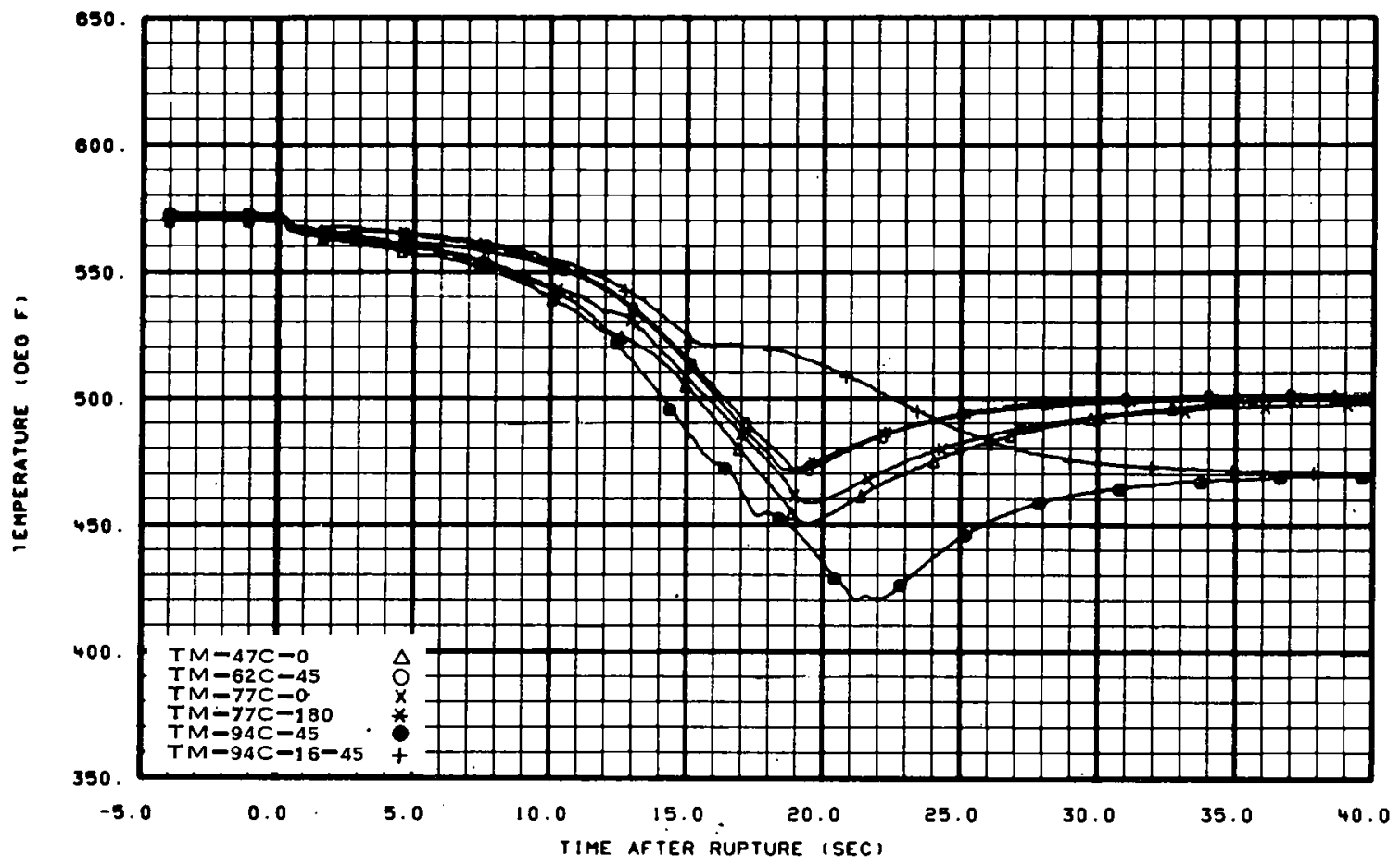

Fig. 21 Metal temperatures in core barrel -- Test 1002.

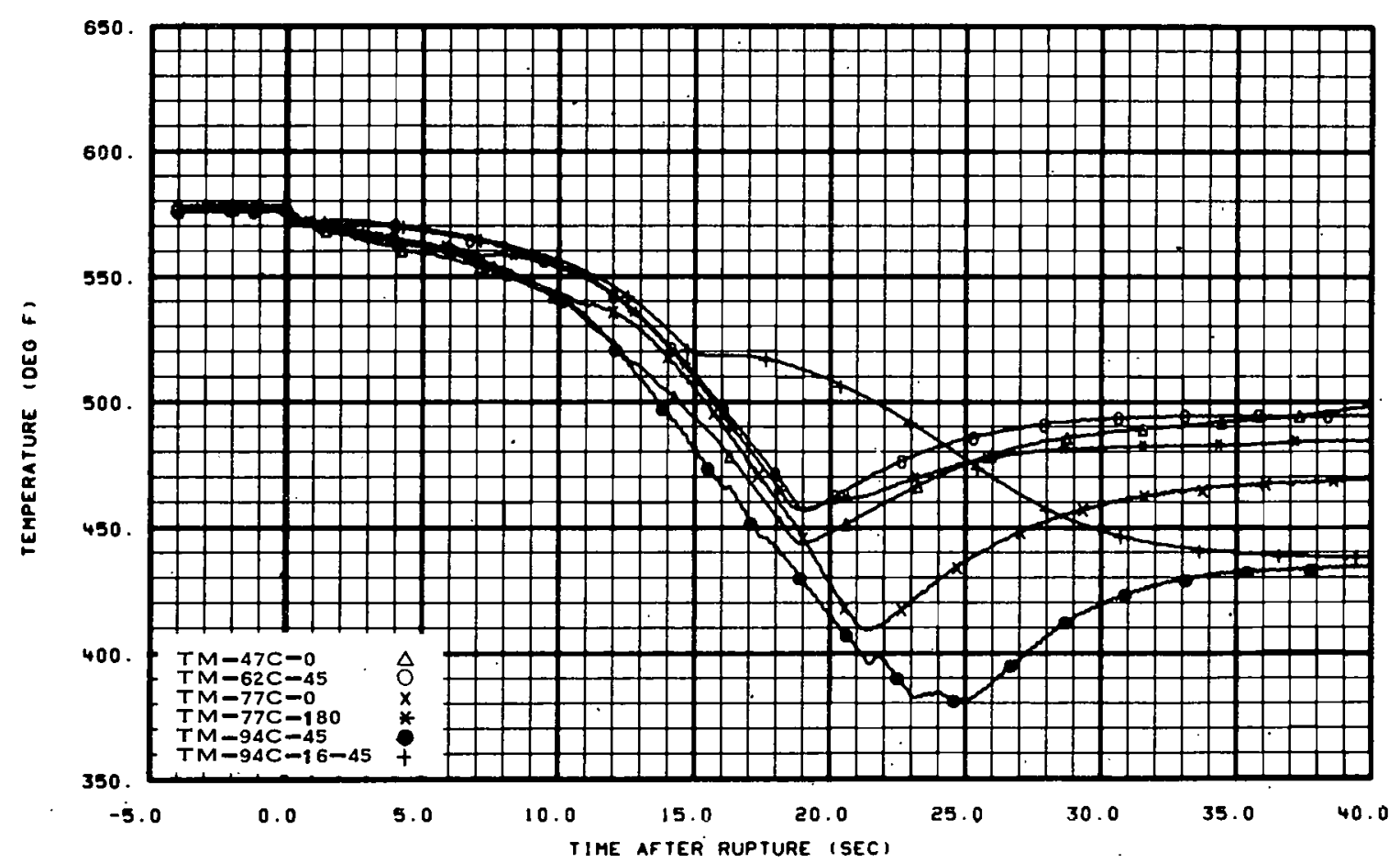

Fig. 22 Metal temperatures in core barrel -- Test 1003. 


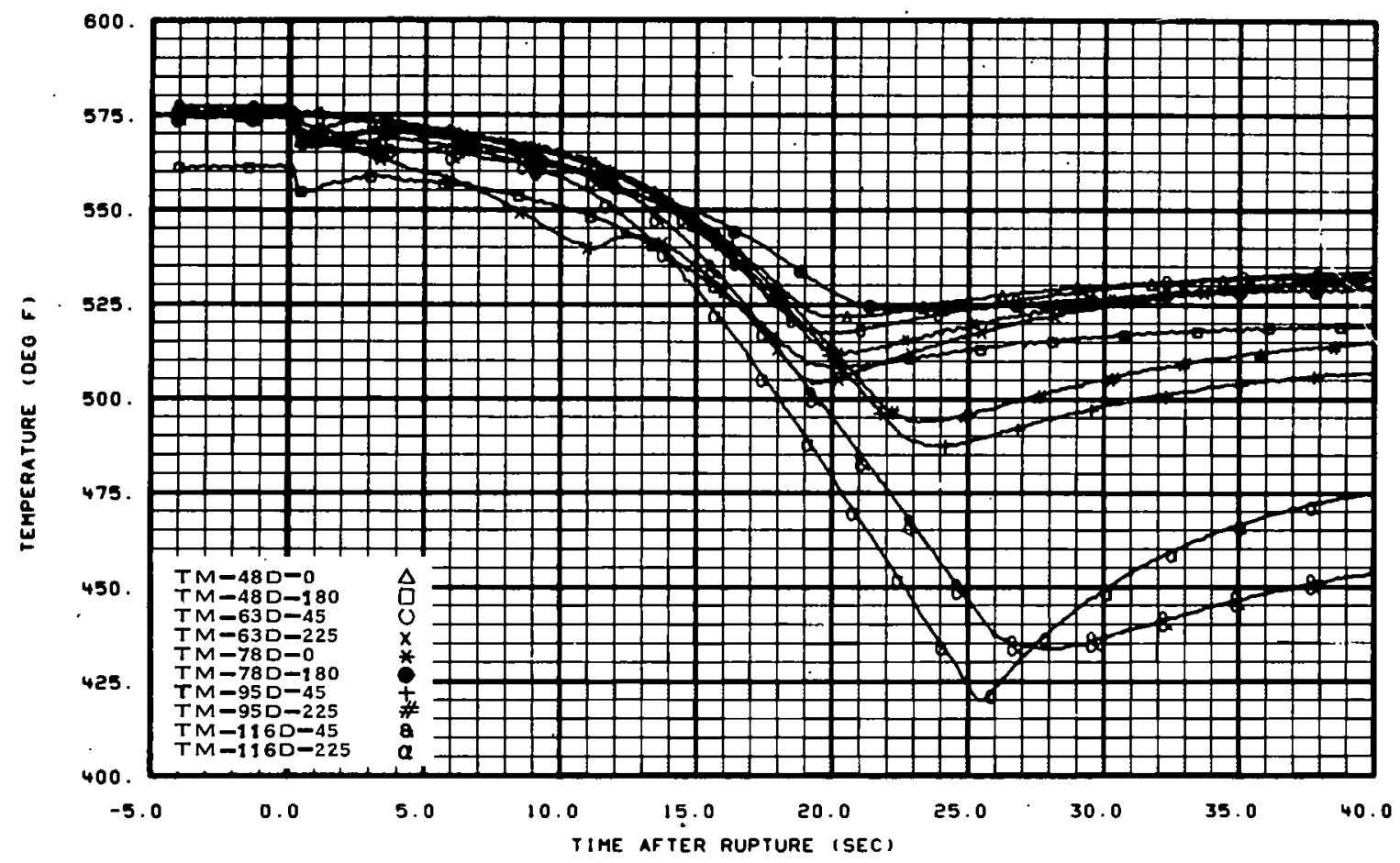

Fig. 23 Metal temperatures in downcomer filler -- Test 1001.

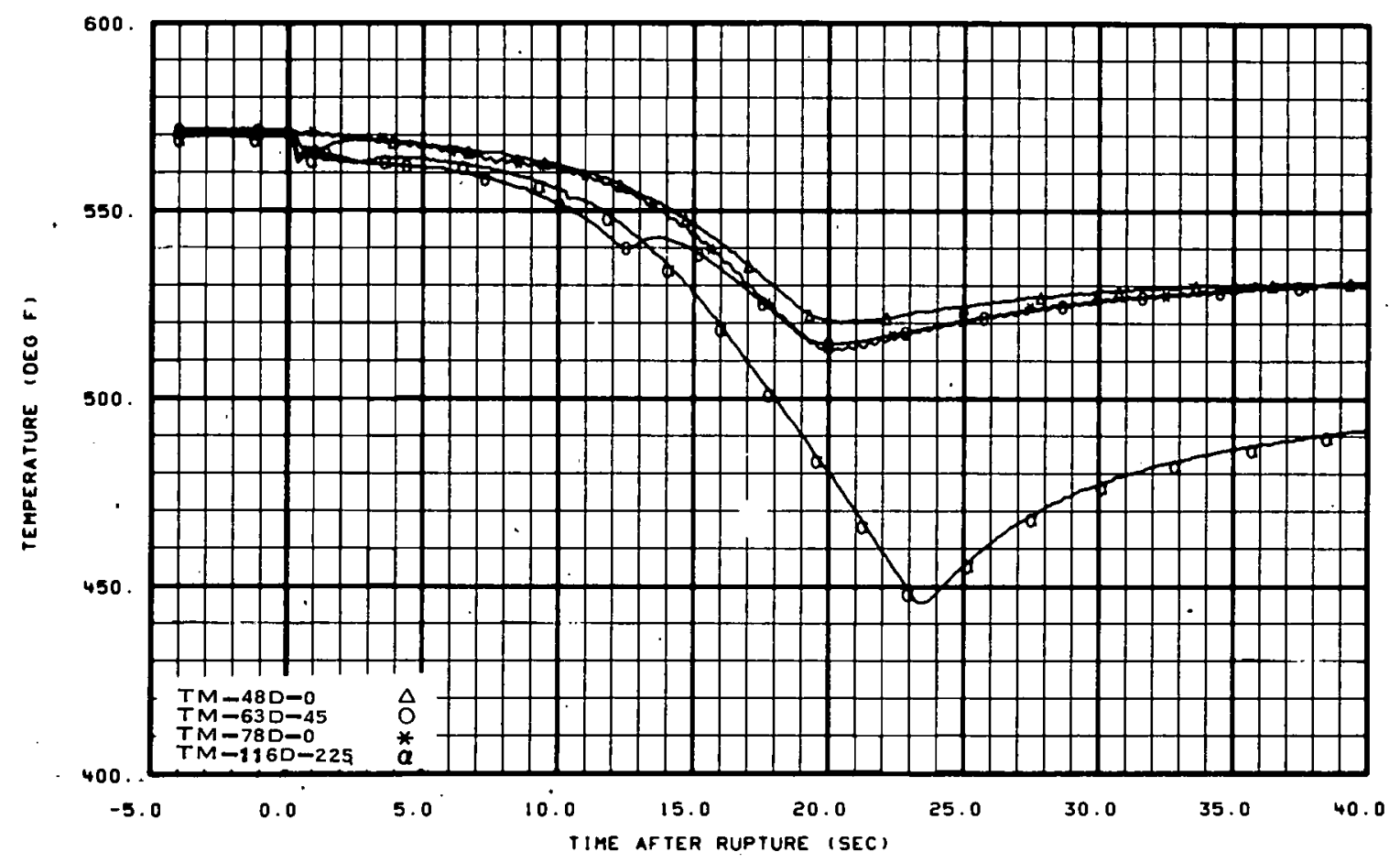

Fig. 24 Metal temperatures in downcomer filler -- Test. 1002. 


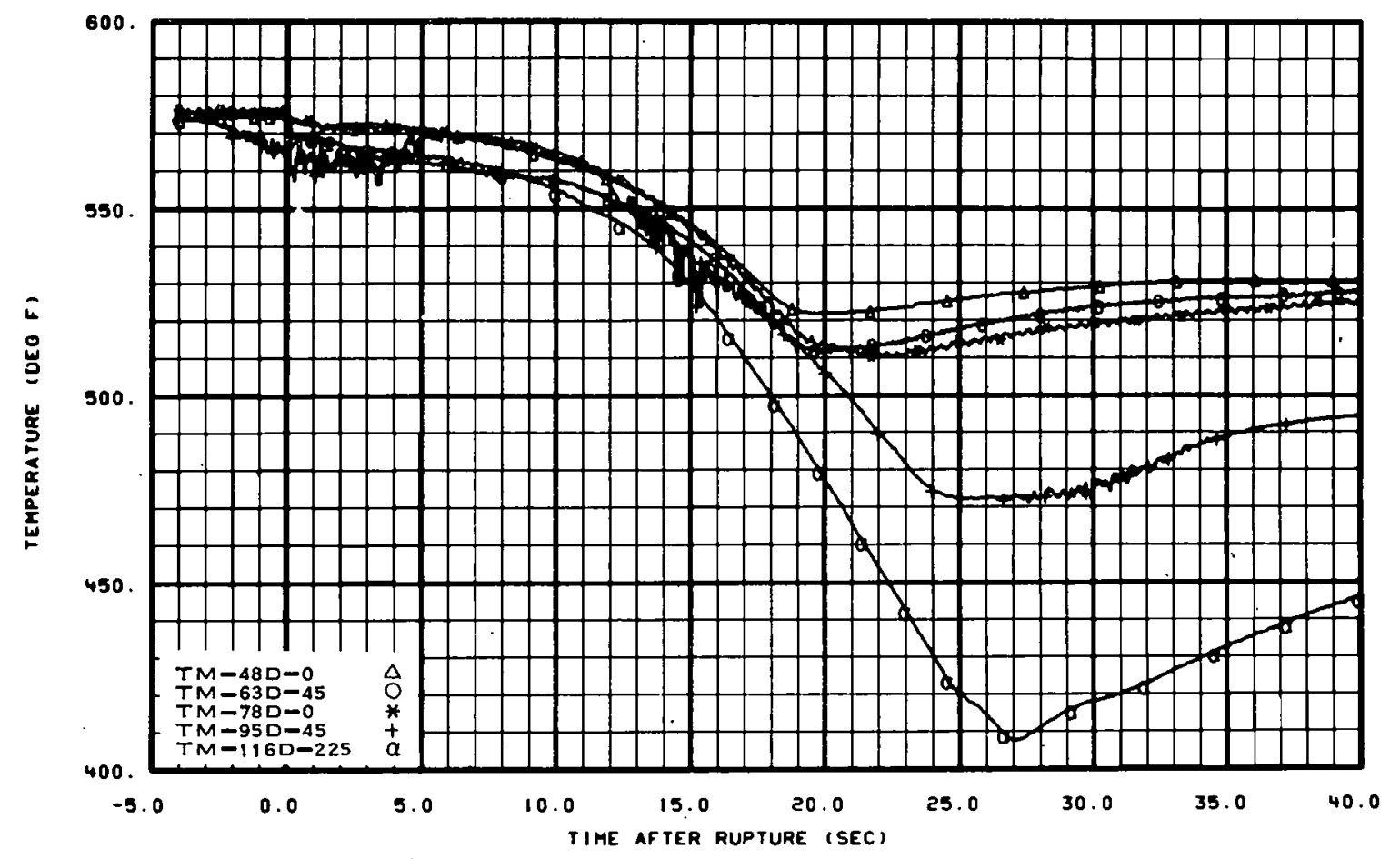

Fig. 25 Metal temperatures in downcomer filler -- Test 1003.

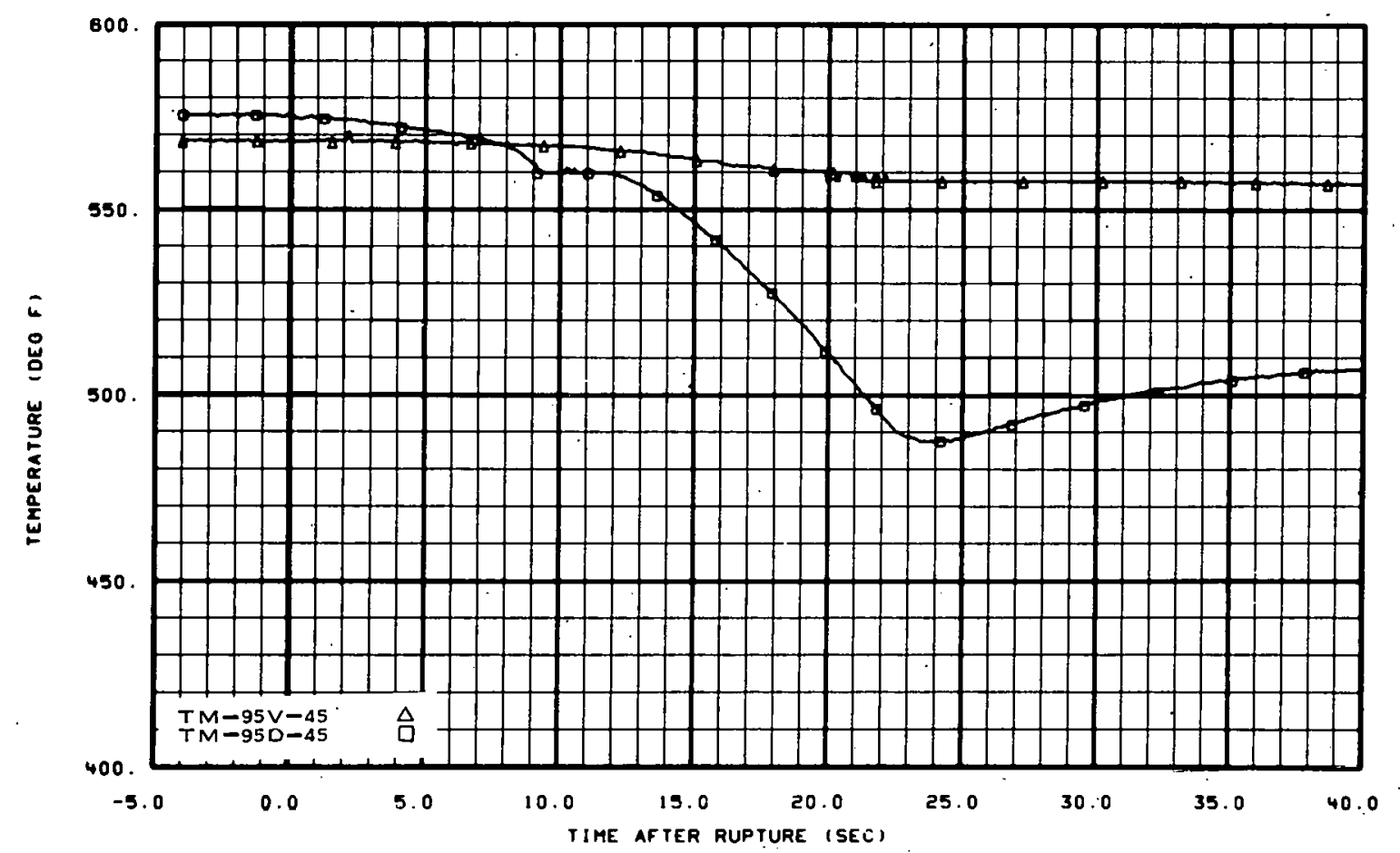

Fig. 26 Metal temperatures in vessel wall 95 inches from vessel upper flange face -- Test 1001 . 


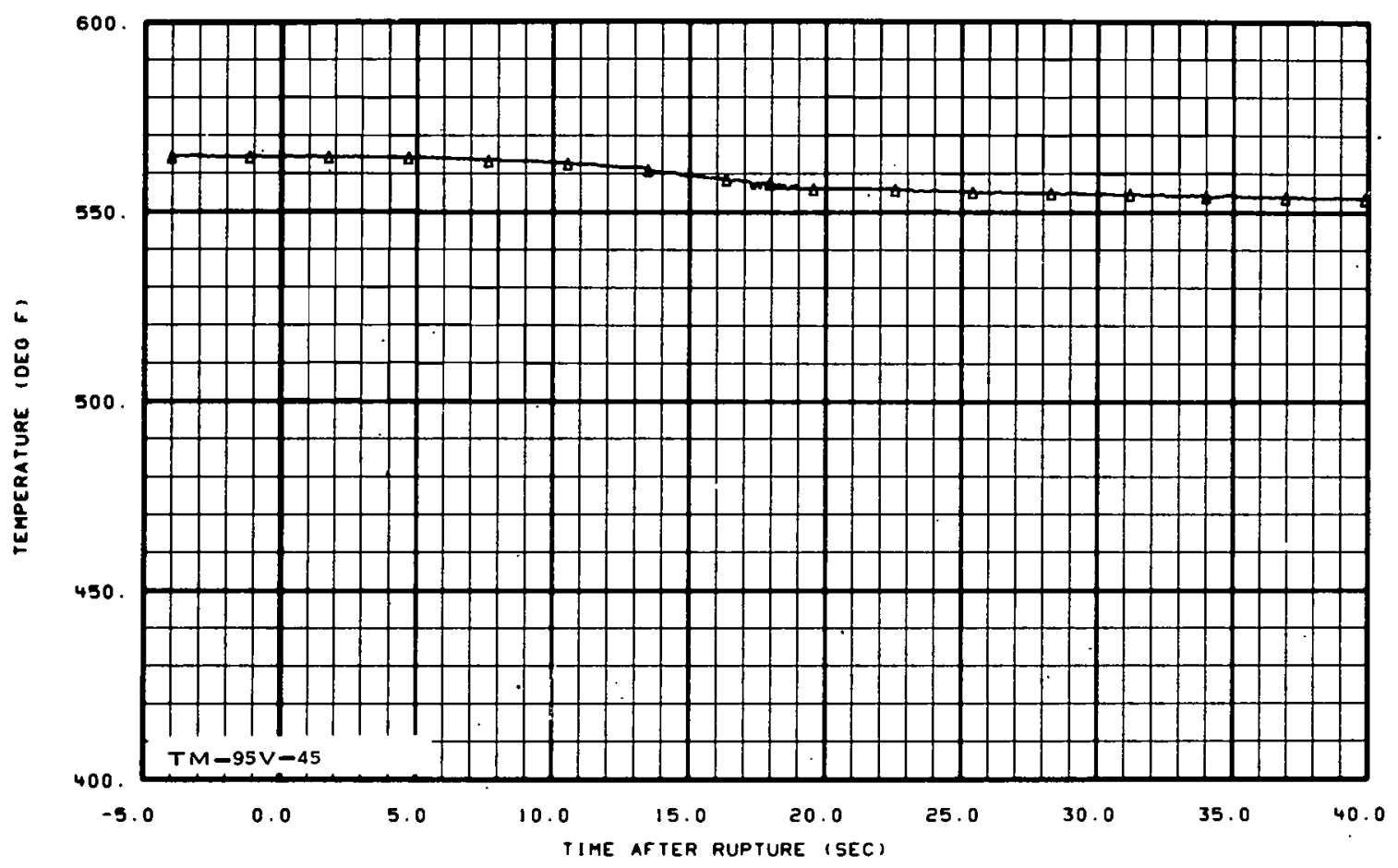

Fig. 27 Metal temperatures in vessel wall 95 inches from vessel upper flange face -- Test 1002 .

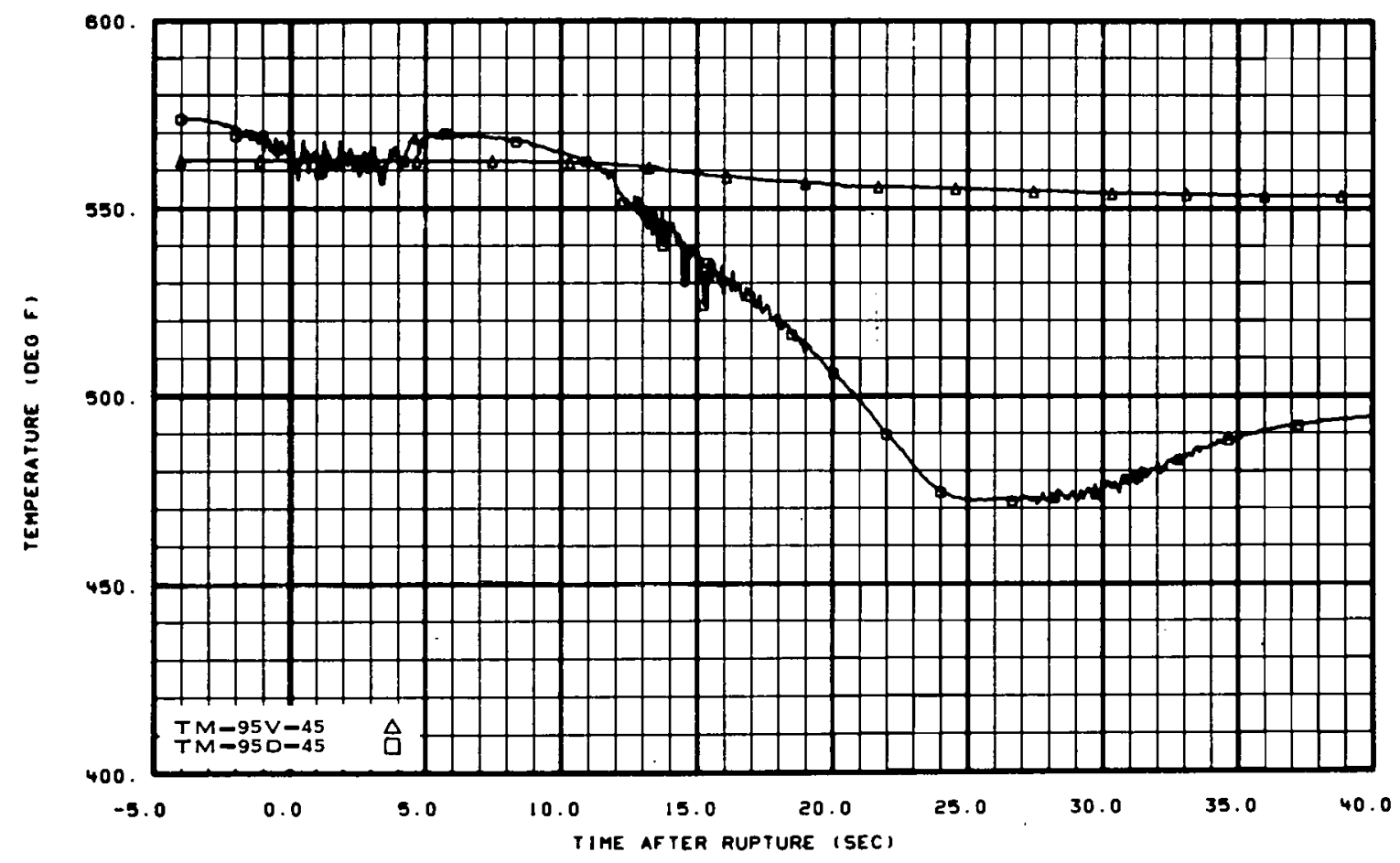

Fig. 28 Metal temperatures in vessel wall 95 inches from vessel upper flange face - Test 1003. 


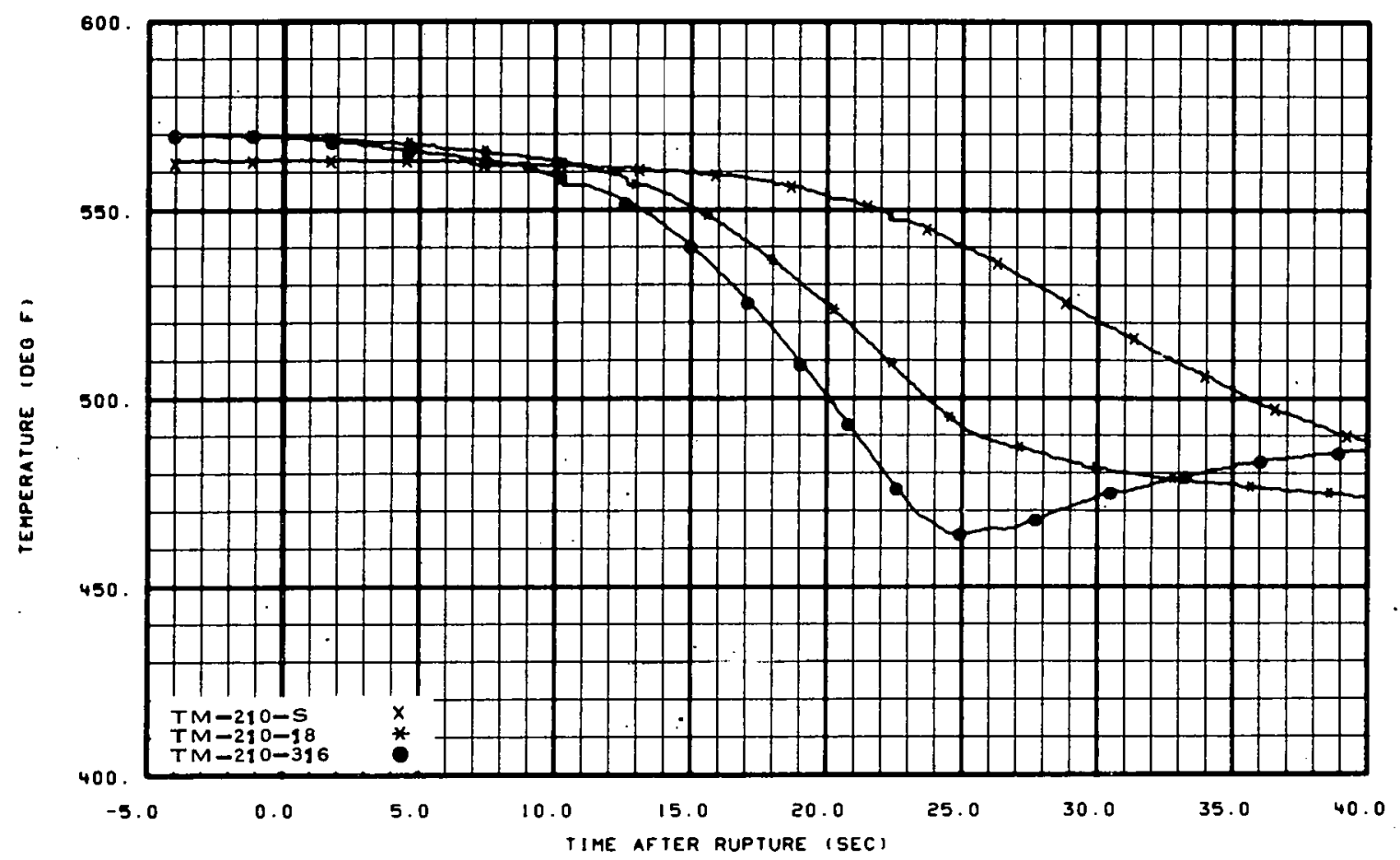

Fig. 29 Metal temperatures in vessel wall -- Test 1002.

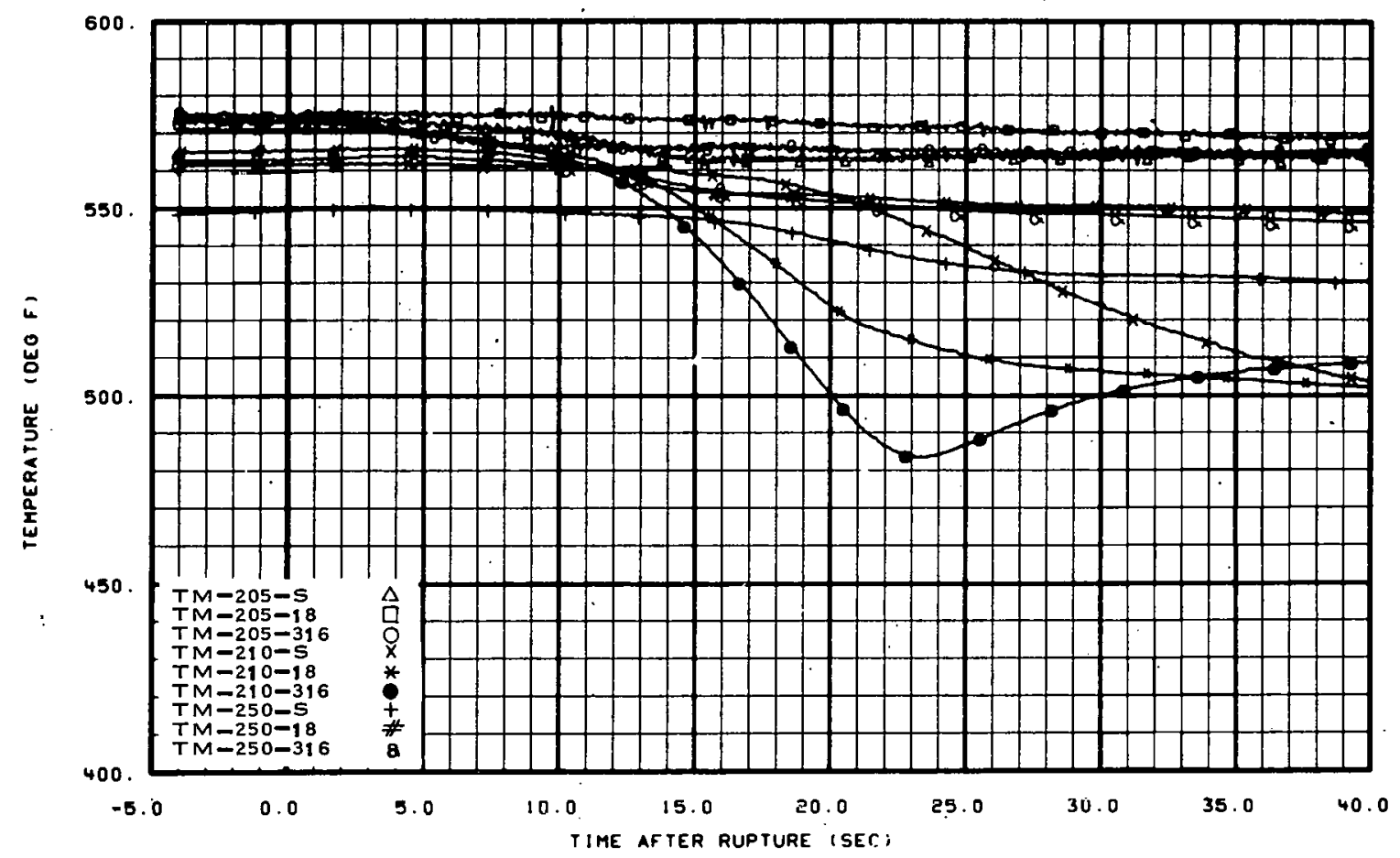

Fig. 30 Metal temperatures in vessel wall -- Test 1003. 


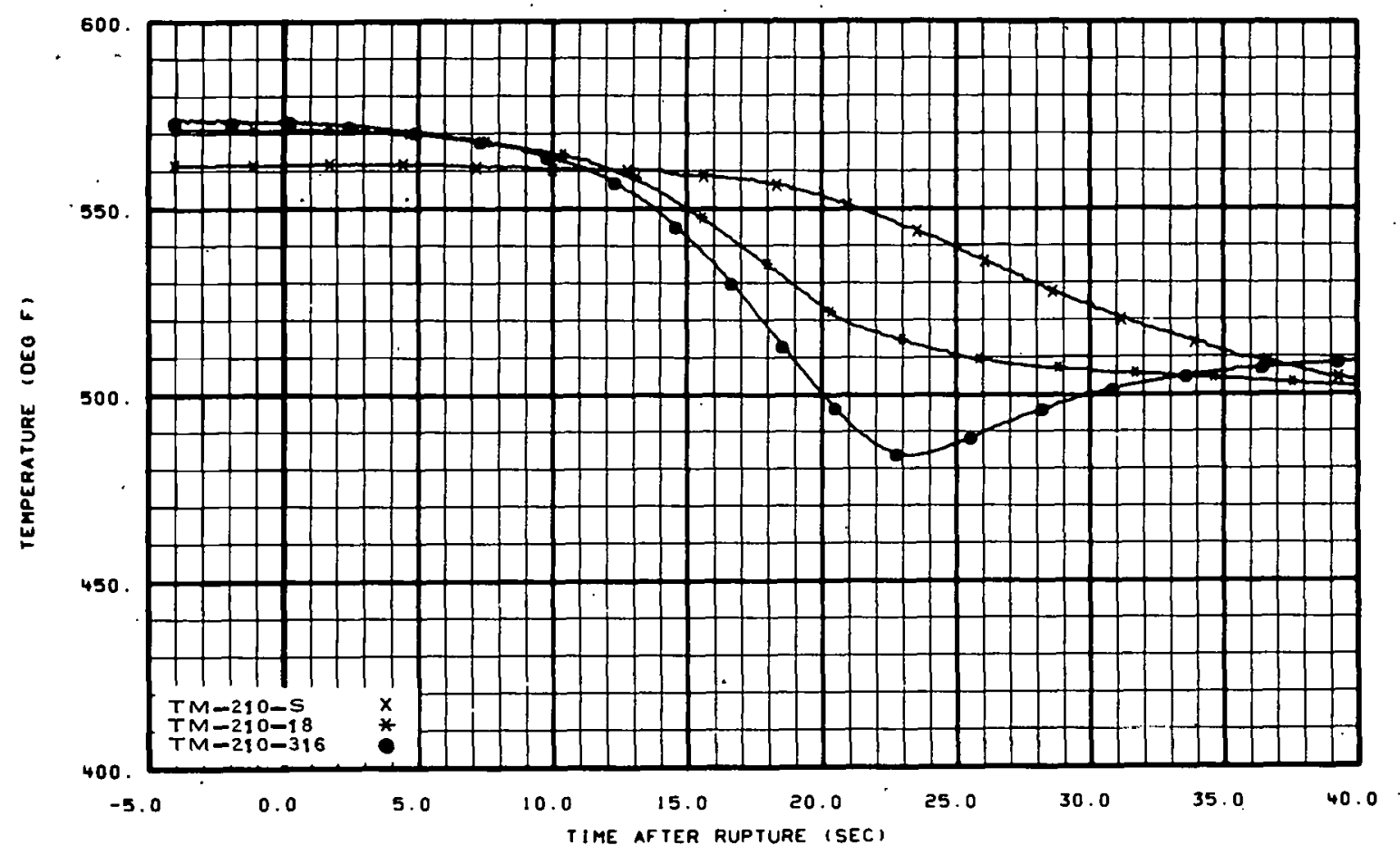

Fig. 31 Metal temperatures in vessel wall -- Test 1003 (separation of Figure 30 for TM-210-S, TM-210-18, and TM-210-316).

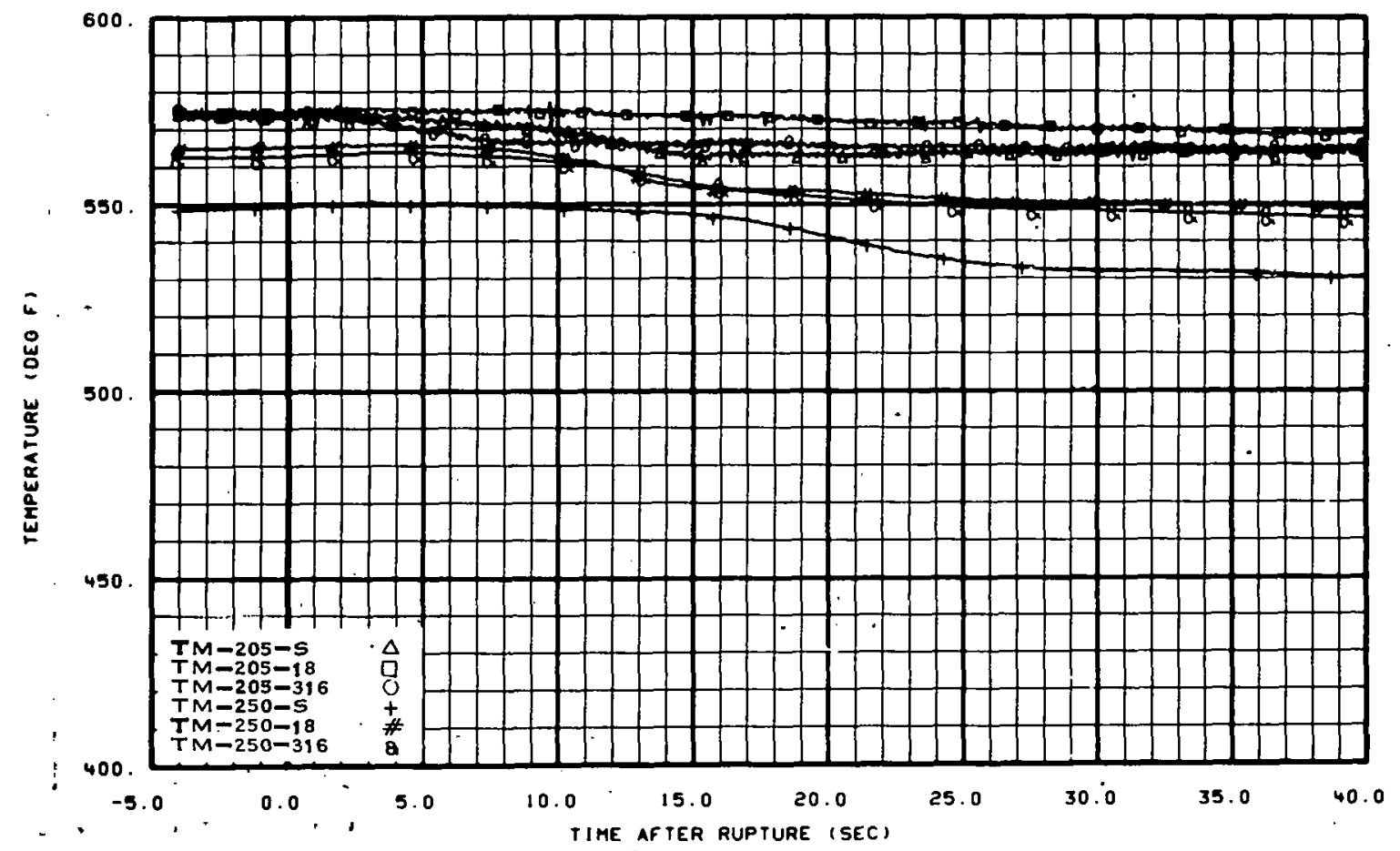

Fig. 32 Metal temperatures in vessel wall -- Test 1003 (separation of Figure 30 for TM-205-S, TM-205-18, TM-205-316, TM-250-S, TM-250-18, and TM-250-316). 


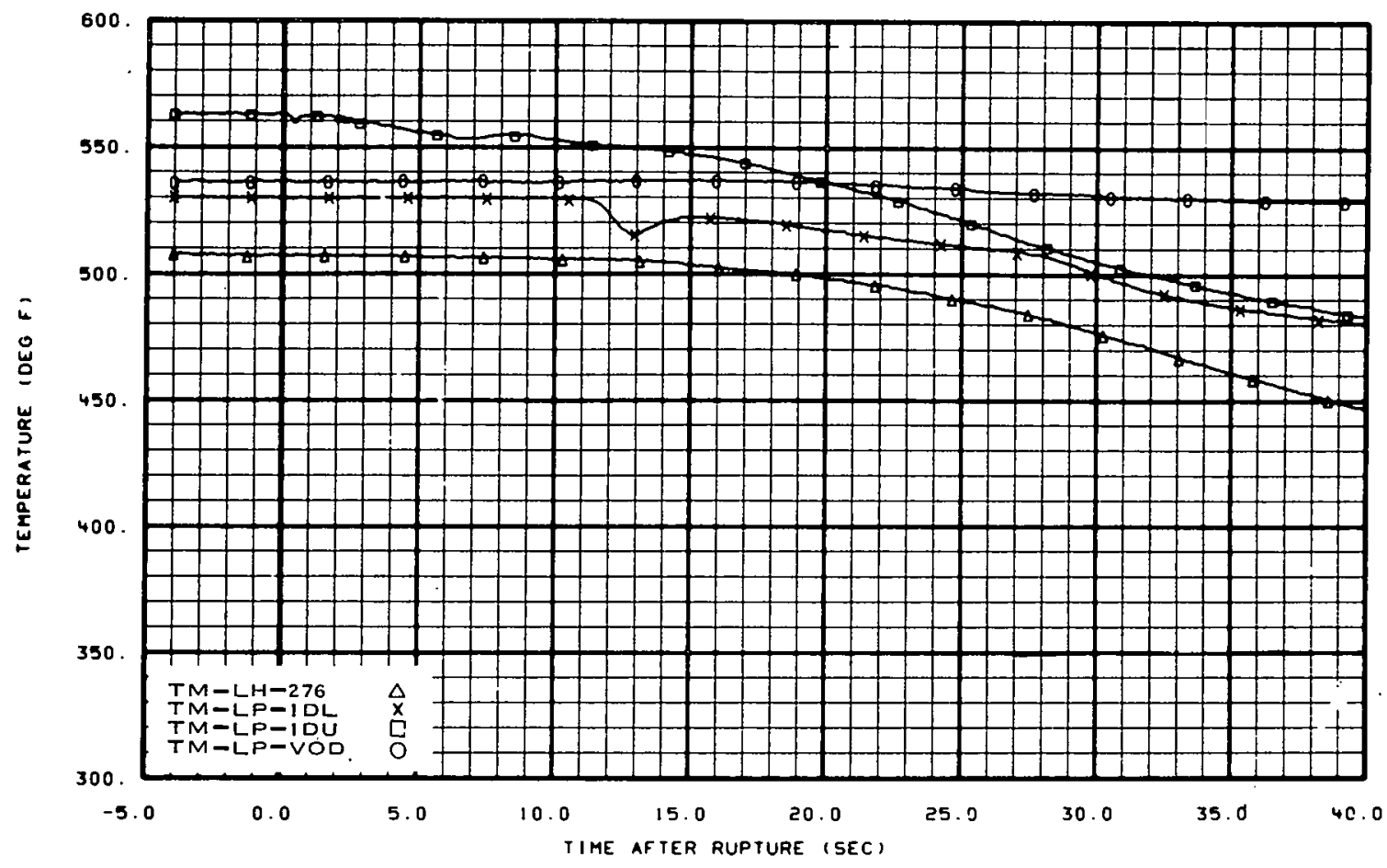

Fig. 33 Metal temperatures in lower plenum vessel wall -- Test 1001.

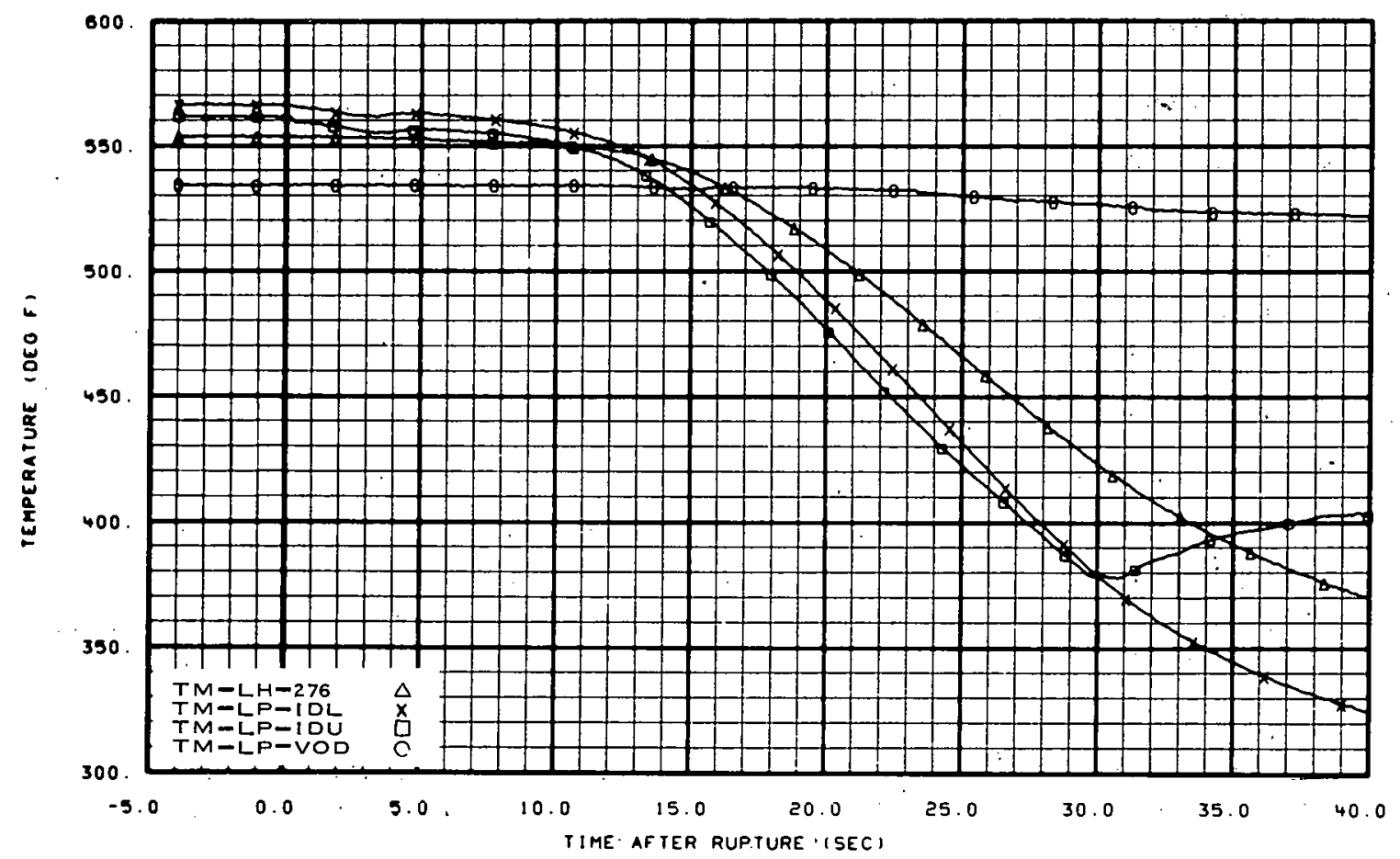

Fig. 34 Metal temperatures in lower plenum vessel wall -- Test 1002. 


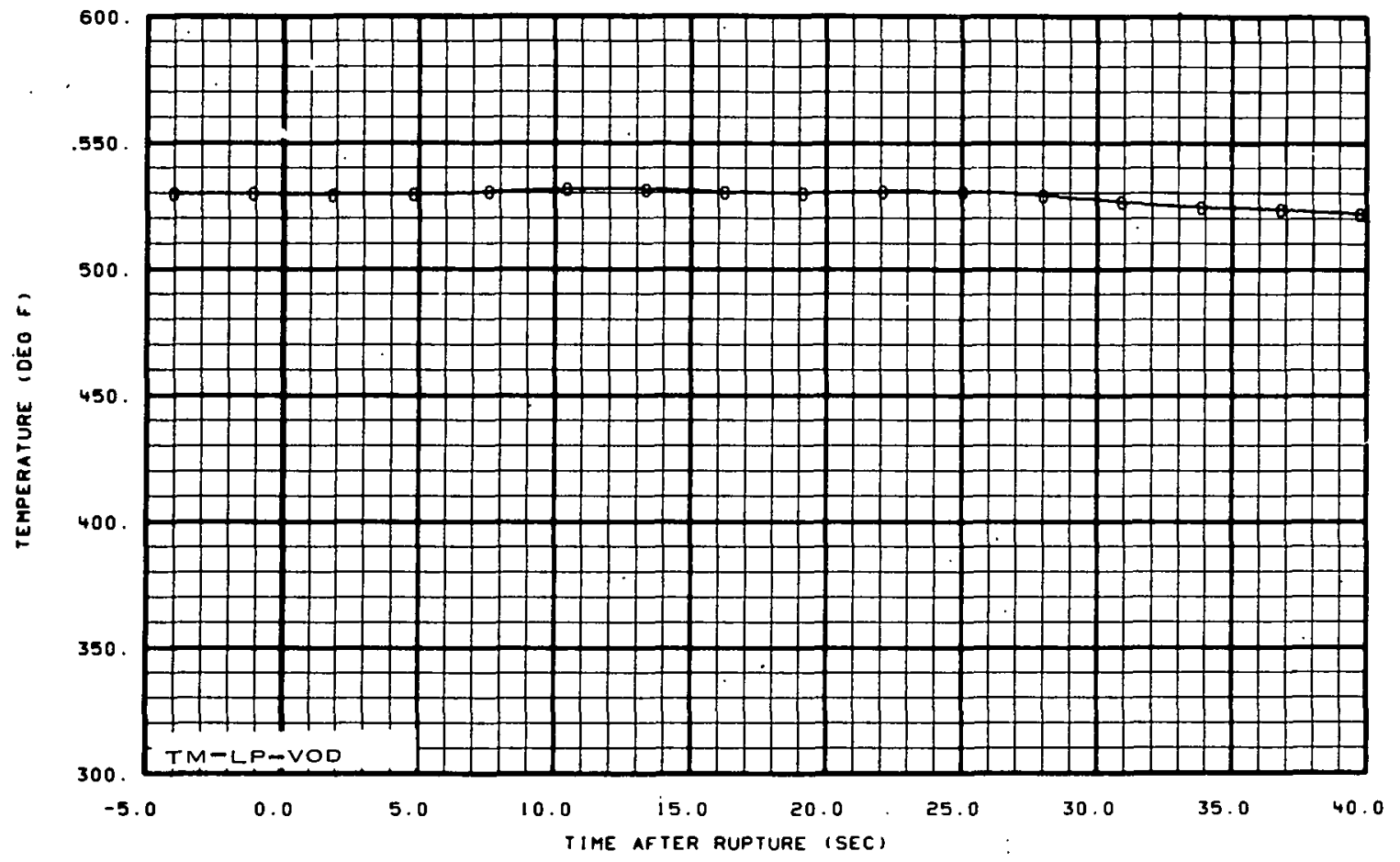

Fig. 35 Metal temperatures in lower plenum vessel wall -- Test 1003.

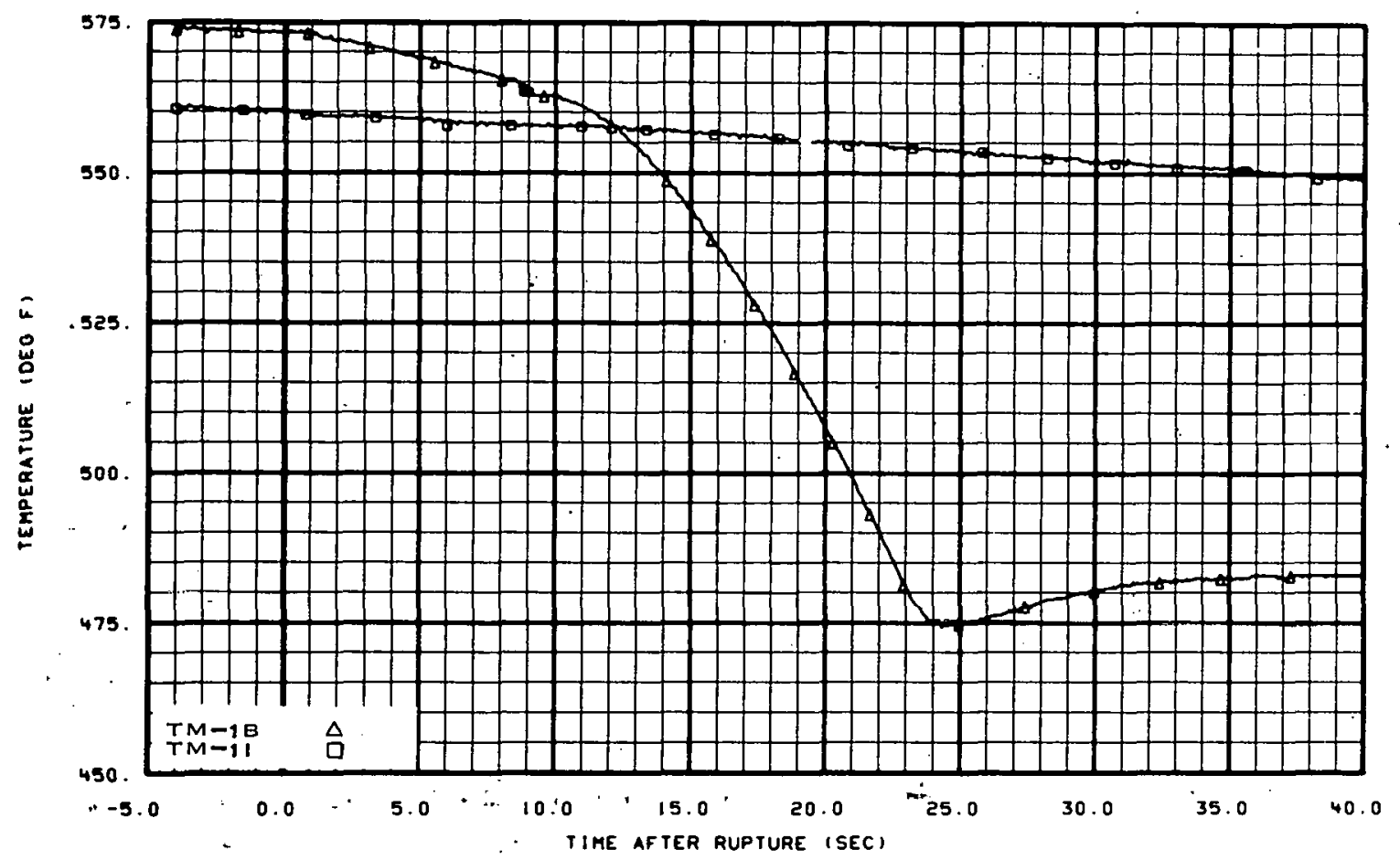

Fig. 36 Metal temperatures in operating loop hot leg .Spool 1 -- Test 1001. 


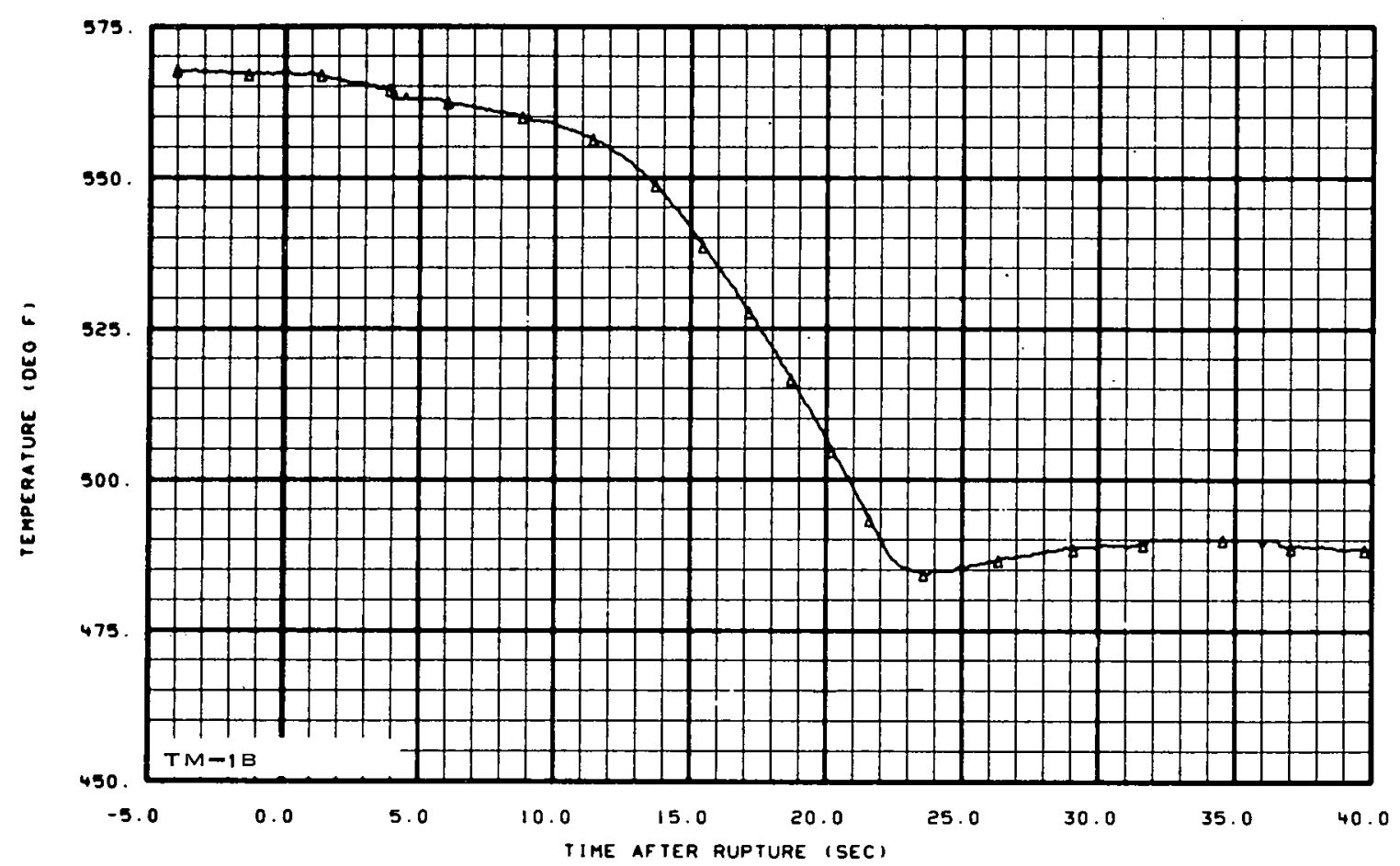

Fig. 37 Metal temperatures in operating loop hot leg Spool 1 -- Test 1002.

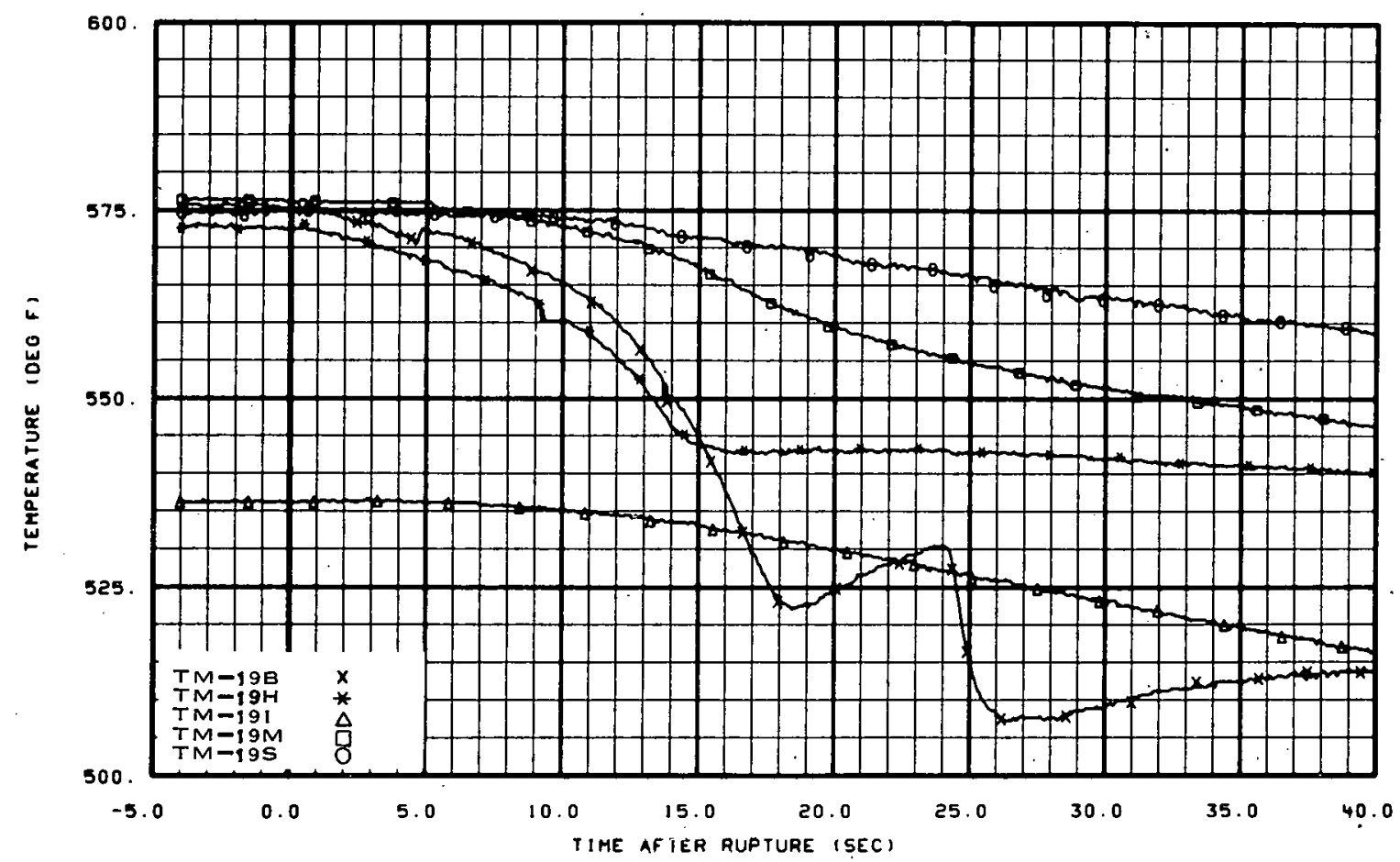

Fig. 38 Metal temperatures in operating loop cold leg Spool 19 -- Test 1001 . 


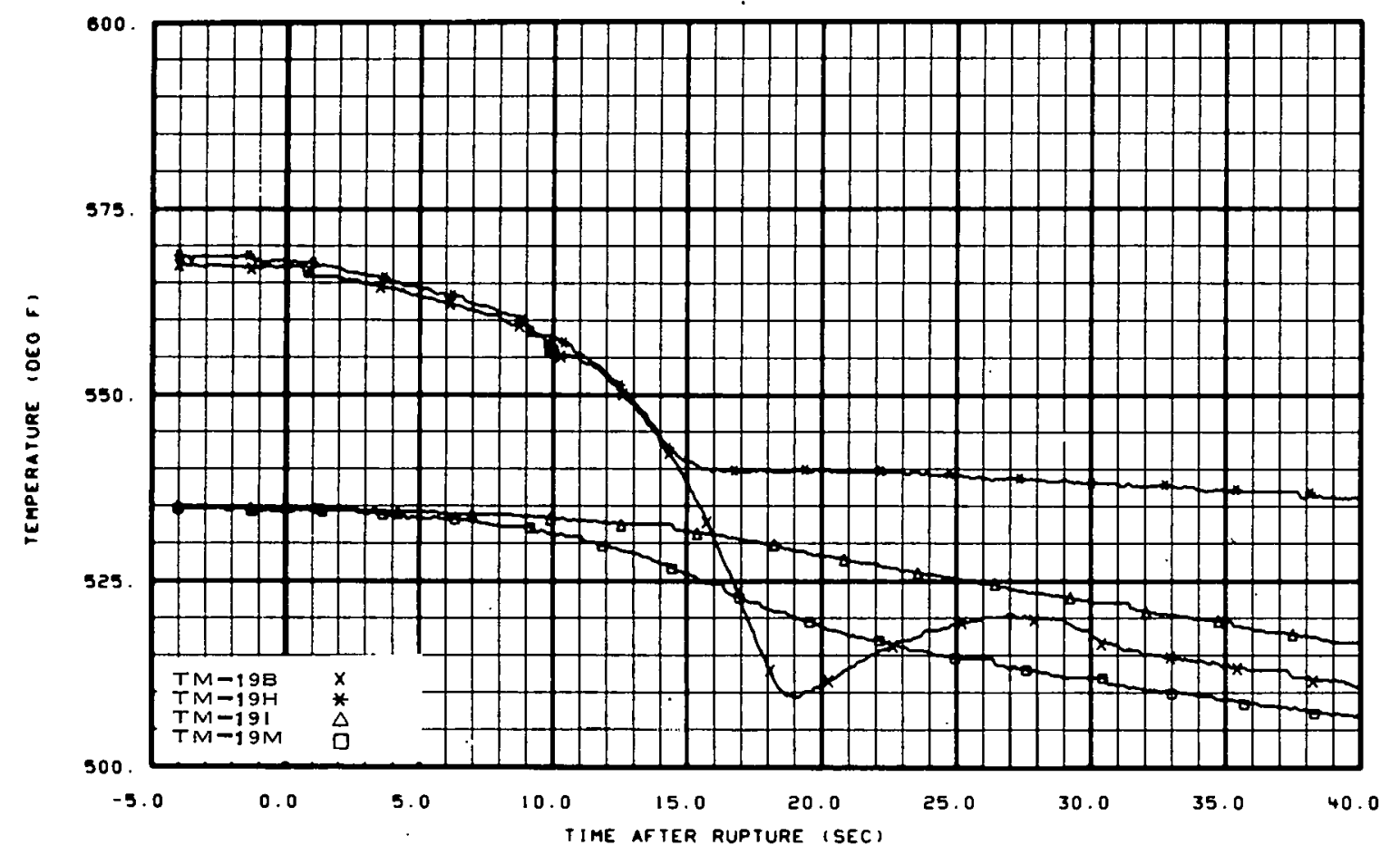

Fig. 39 Metal temperatures in operating loop cold leg Spool 19. - Test 1002.

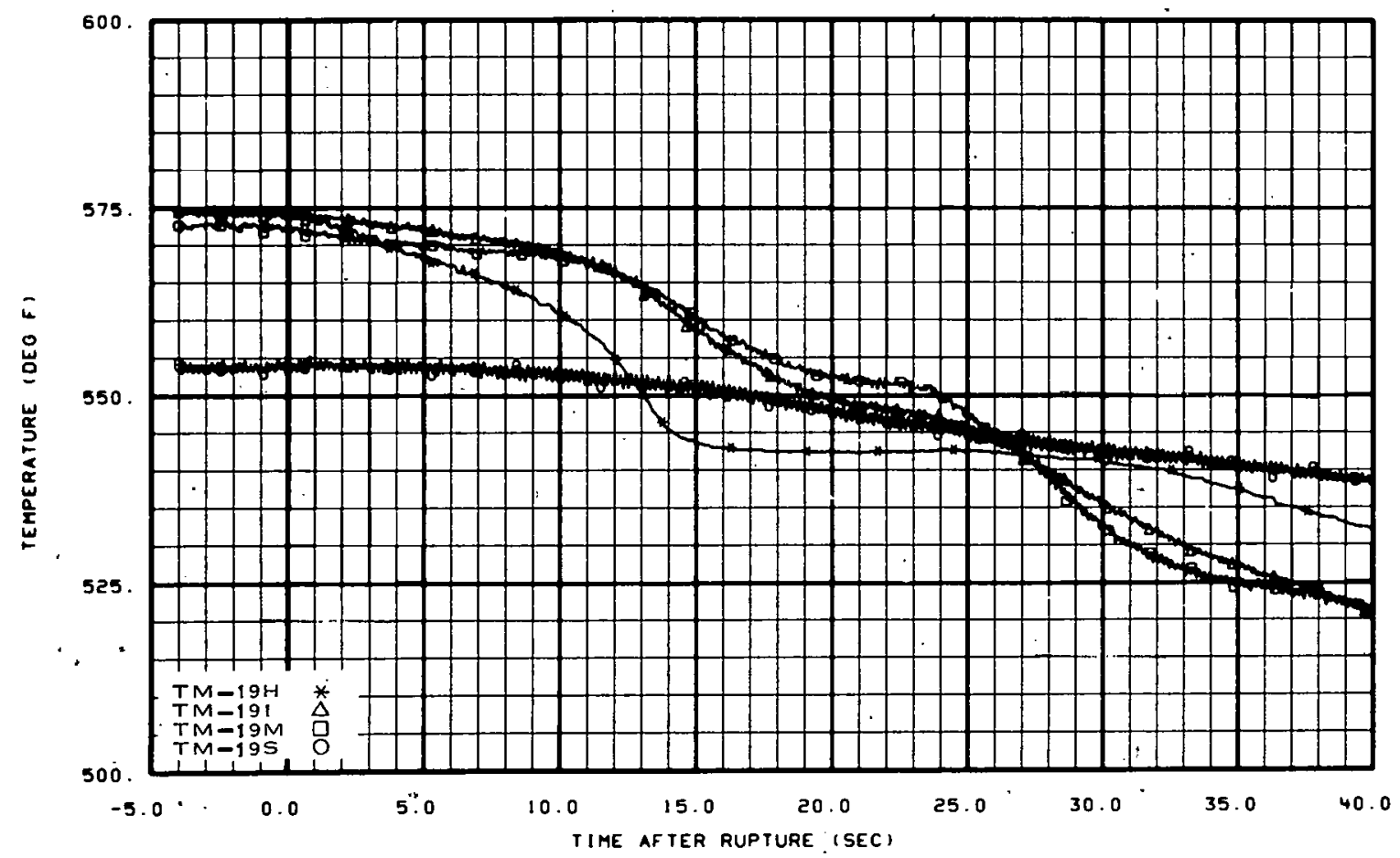

Fig. 40 Metal temperatures in operating loop cold leg. Spool 19:- Test." 1003. 


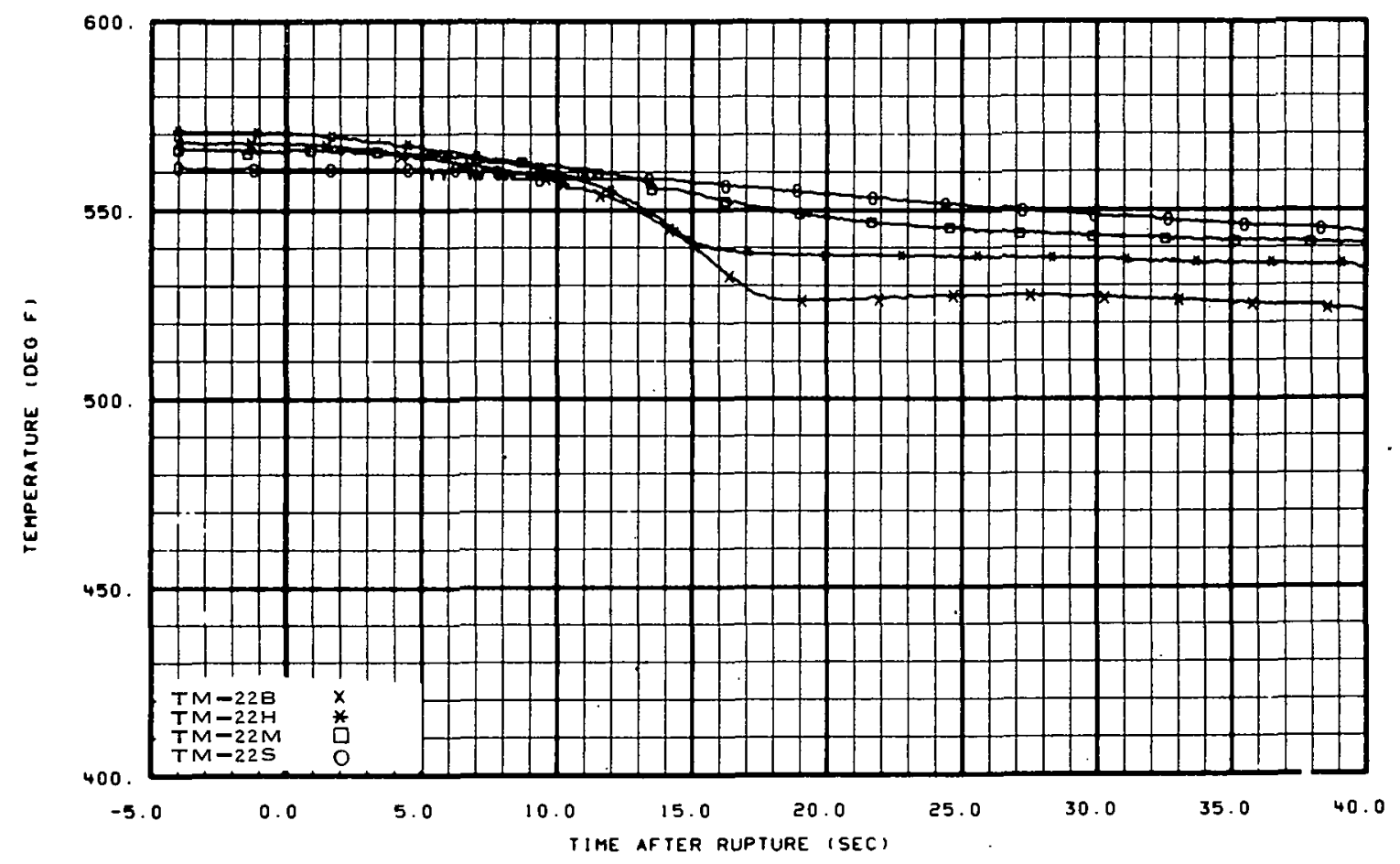

Fig. 41 Metal temperatures in operating loop cold leg Spool 22 -- Test 1001 .

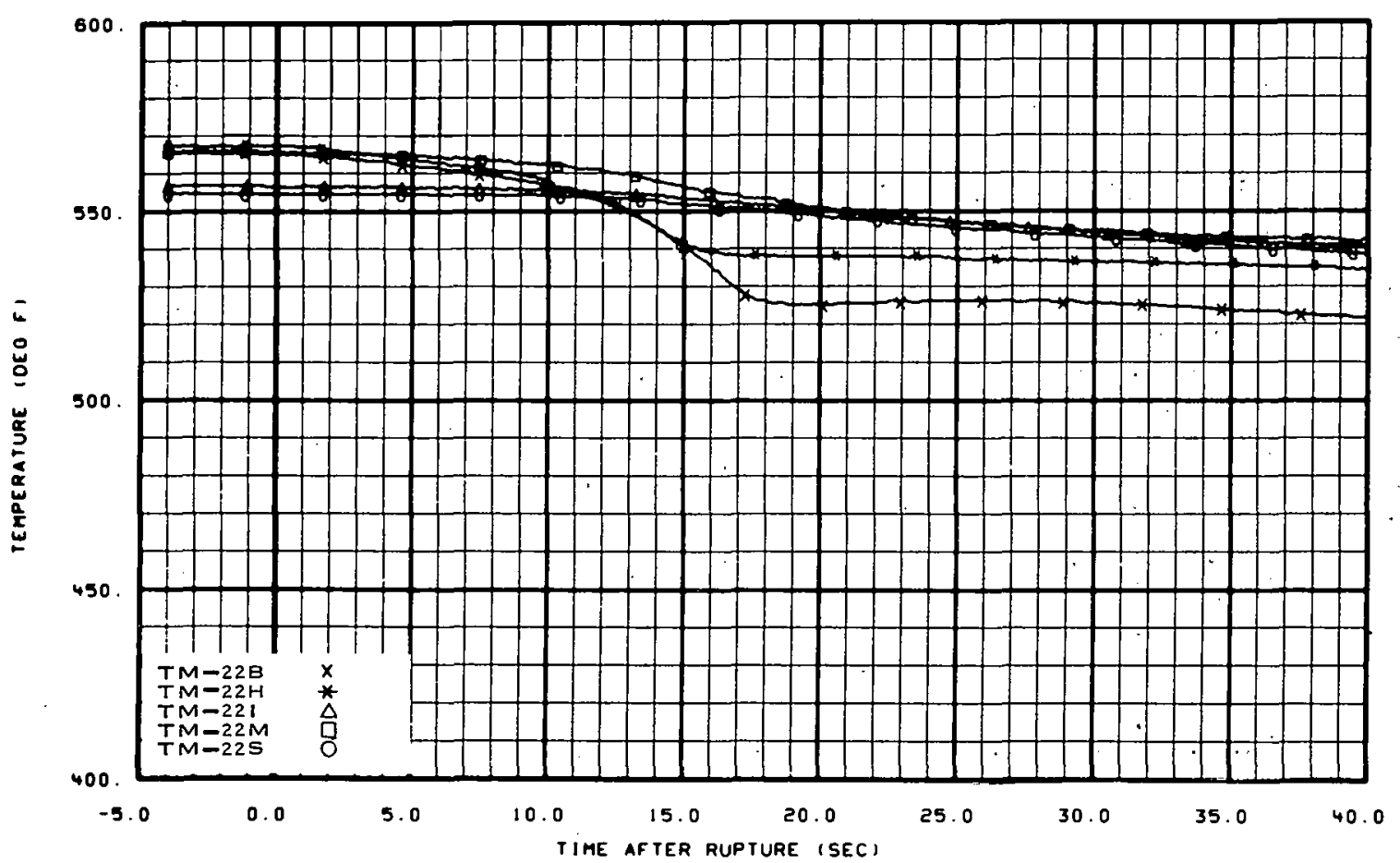

Fig. 42 Metal temperatures in operating loop cold leg Spooi 22 -- Test 1002 . 


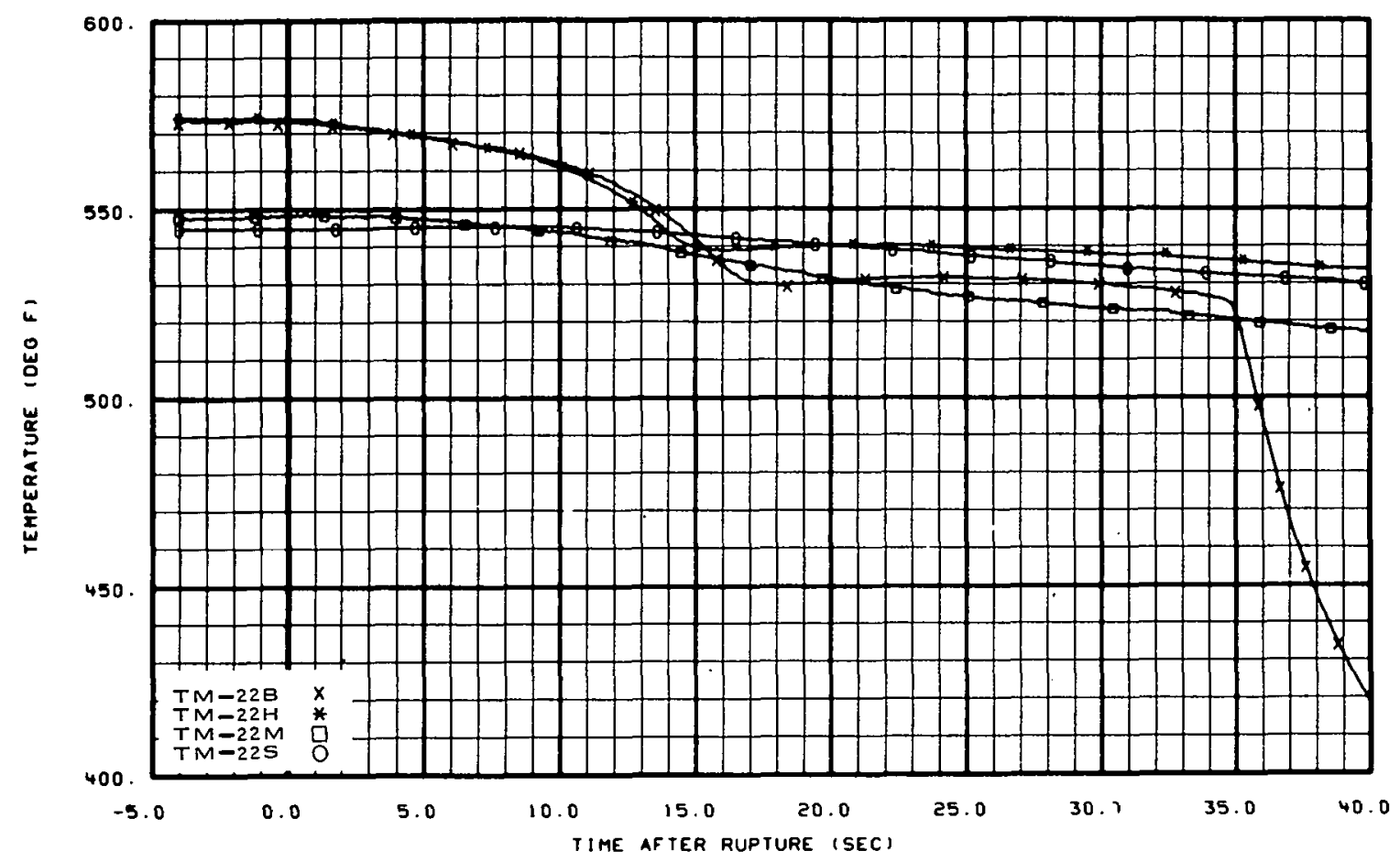

Fig. 43 Metal temperatures in operating loop cold leg Spool 22 -- Test 1003.

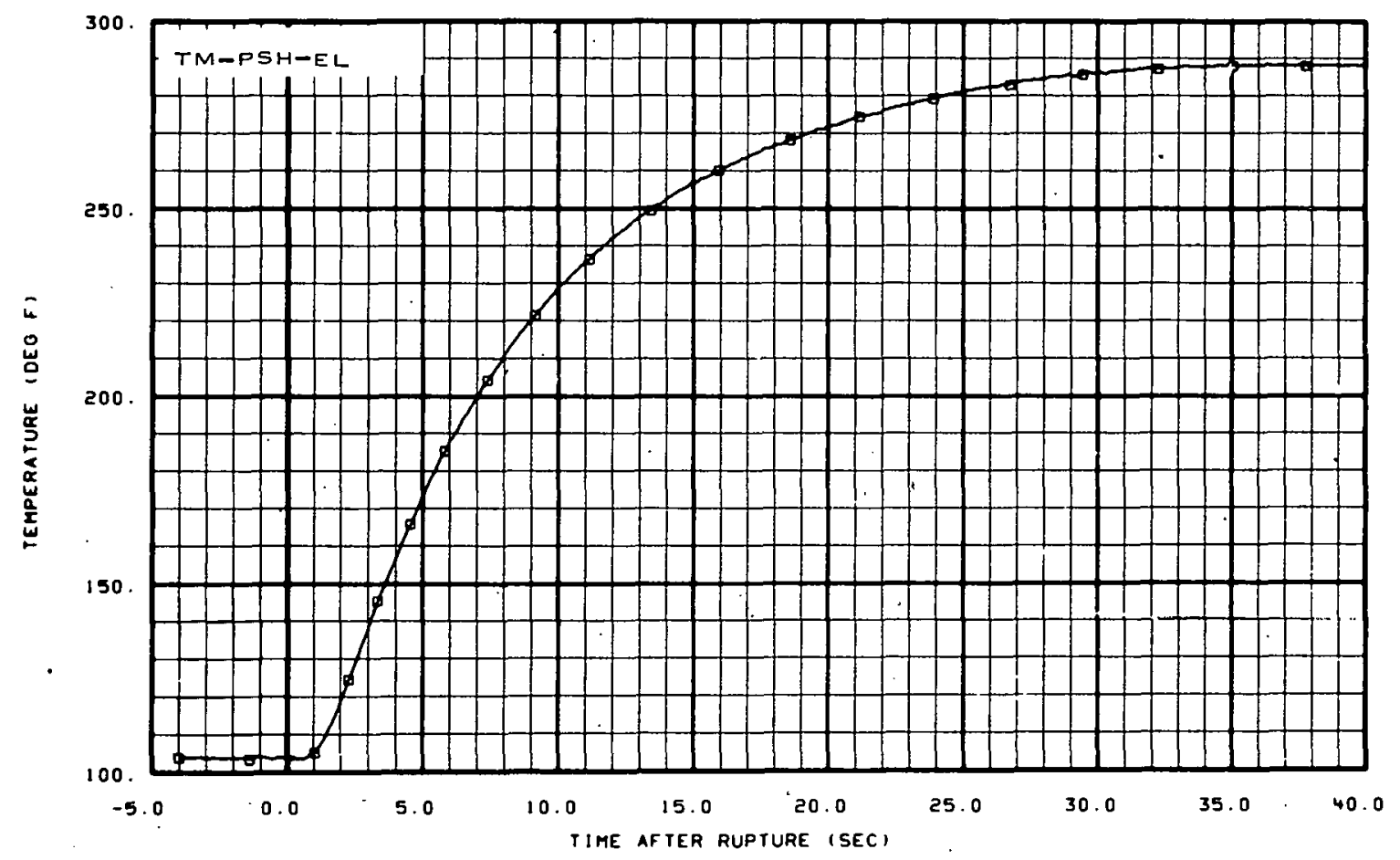

Fig. 44 Metal temperatures in pressure suppression system -- Test 1001. 


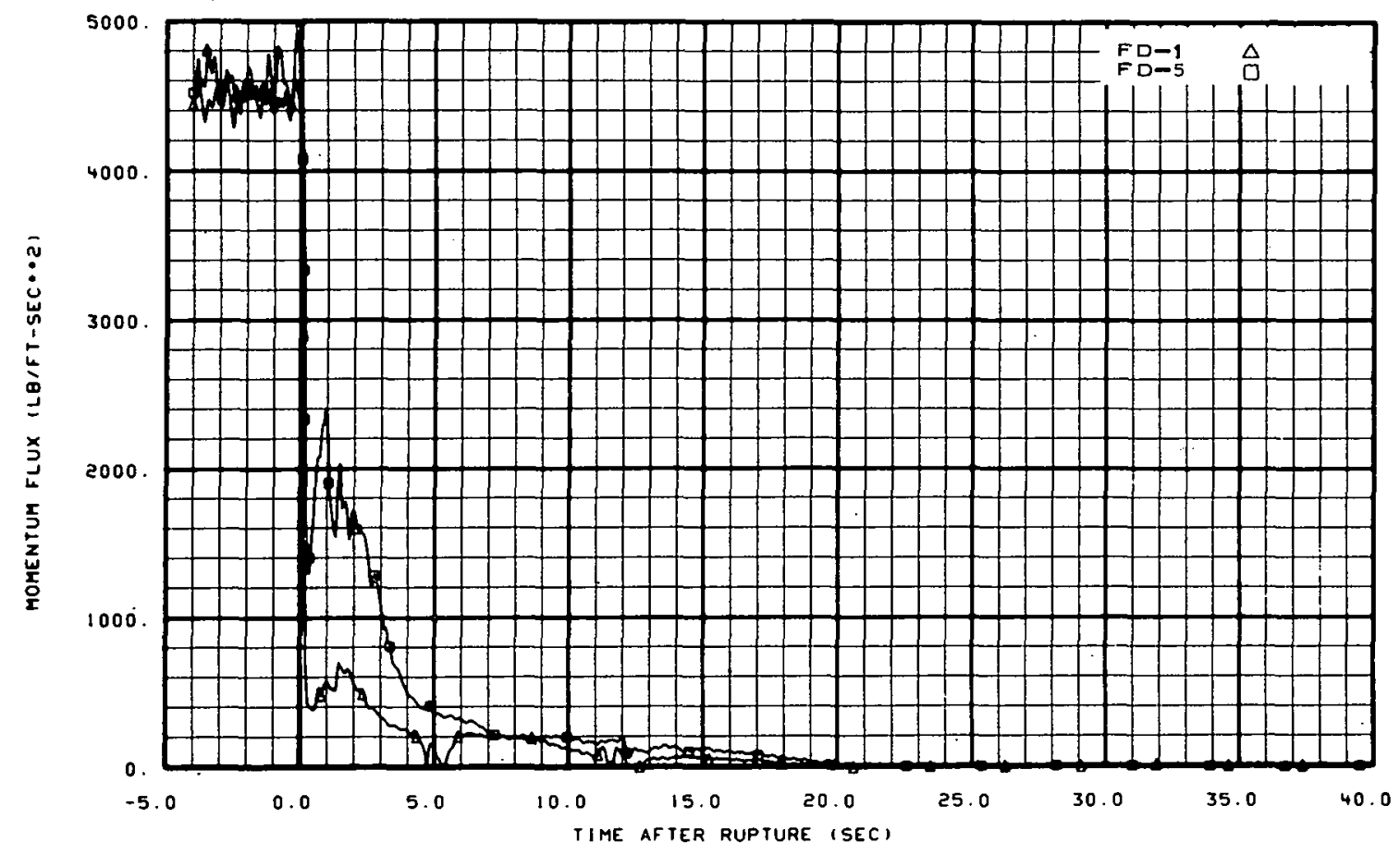

Fig. 45 Momentum flux from drag discs in operating loop hot leg -- Test 1001 .

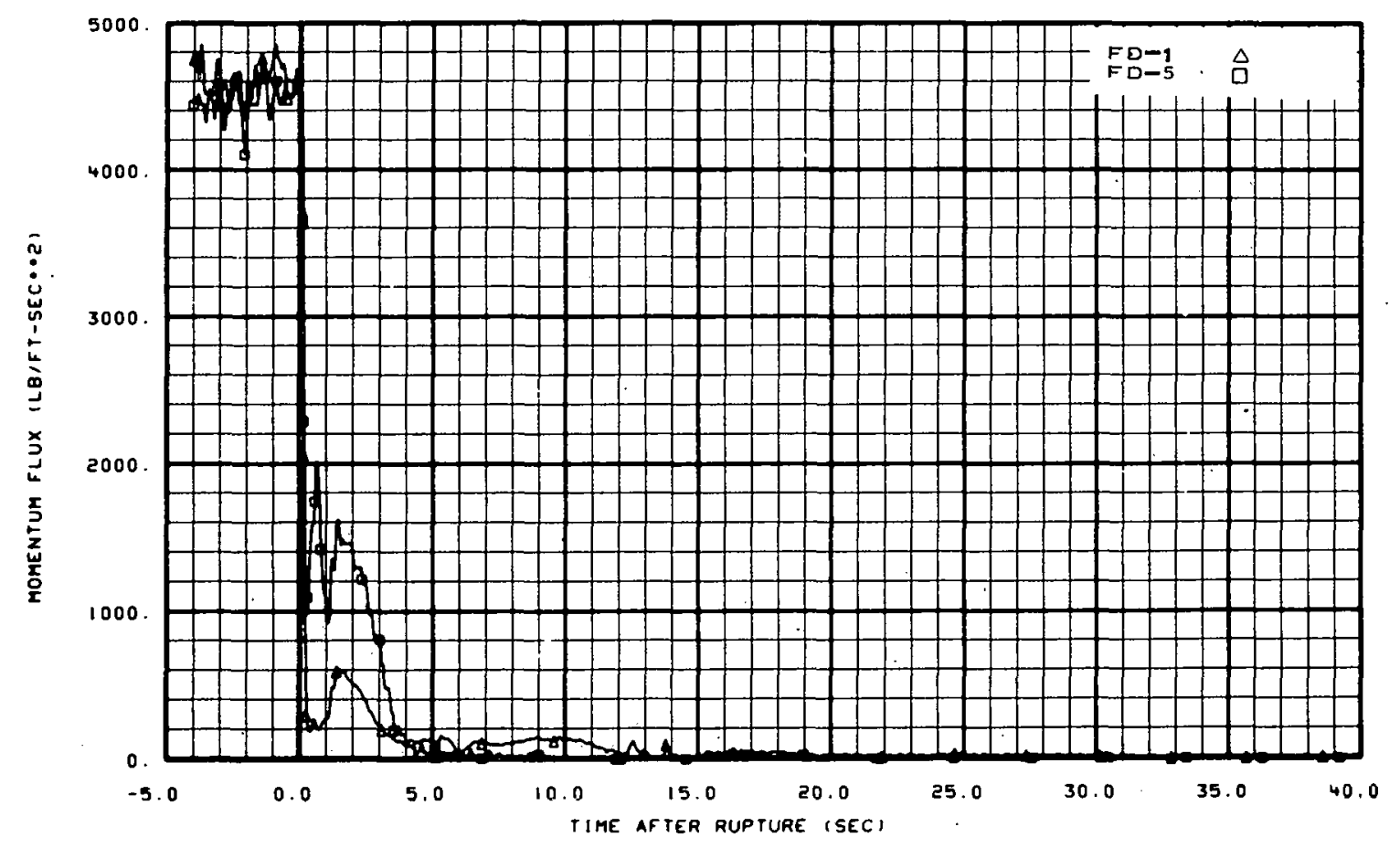

Fig. 46 Momentum flux from drag discs in operating loop hot. leg -- Test 1002 . 


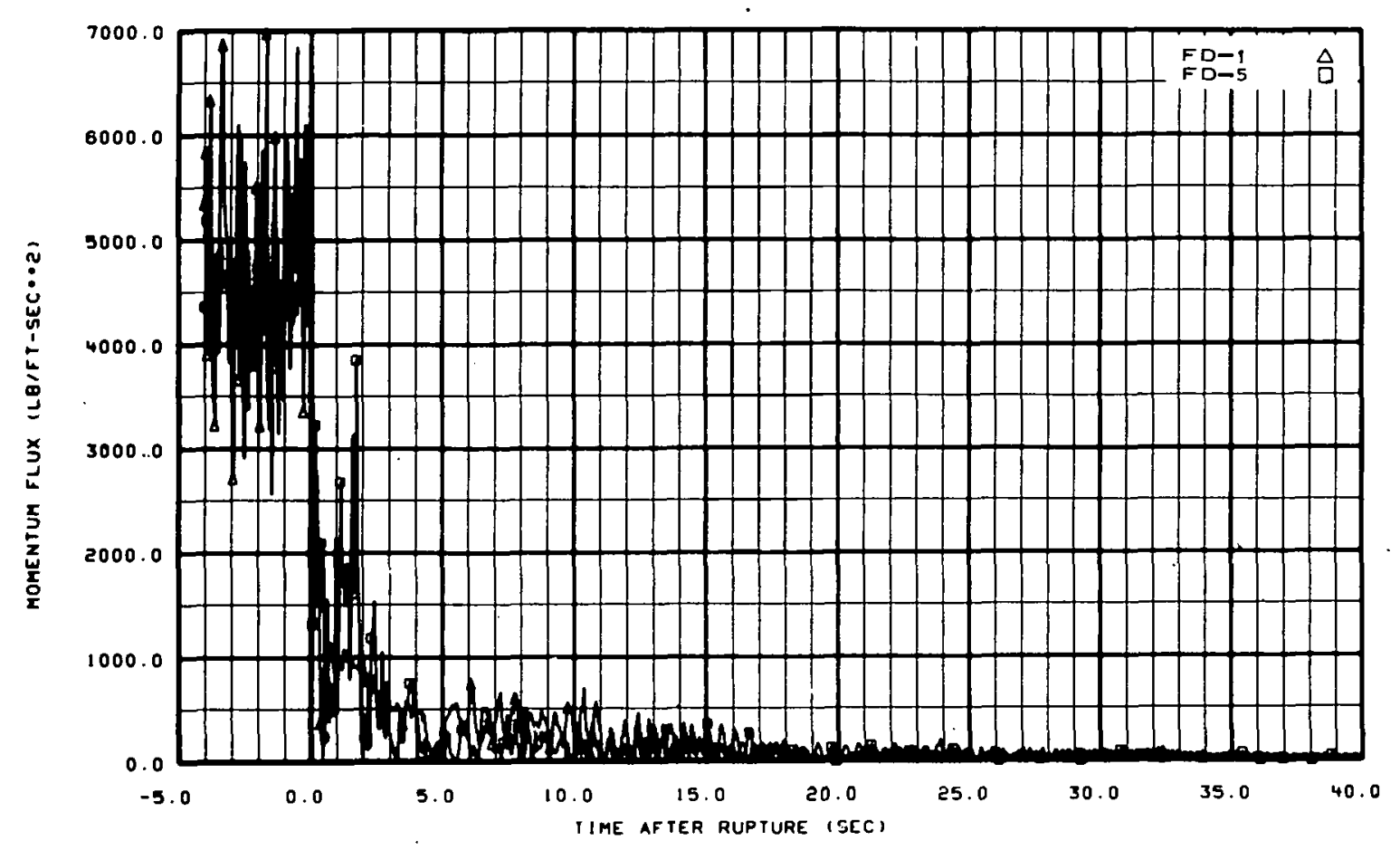

Fig. 47 Momentum flux from drag discs in operating loop hot leg -- Test 1003 .

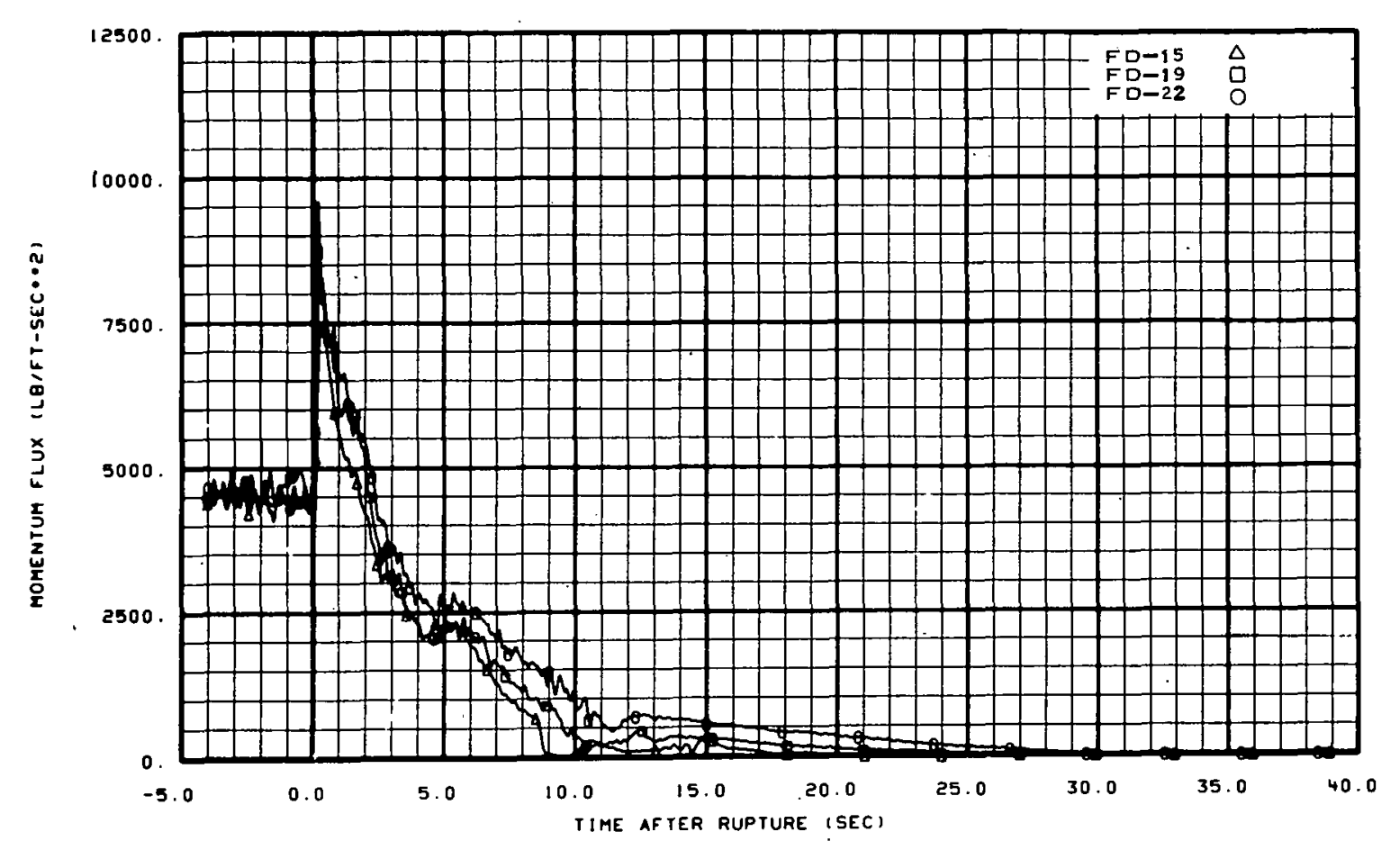

Fig. 48 Momentum flux from drag discs in operating loop cold leg -- Test 1001 . 


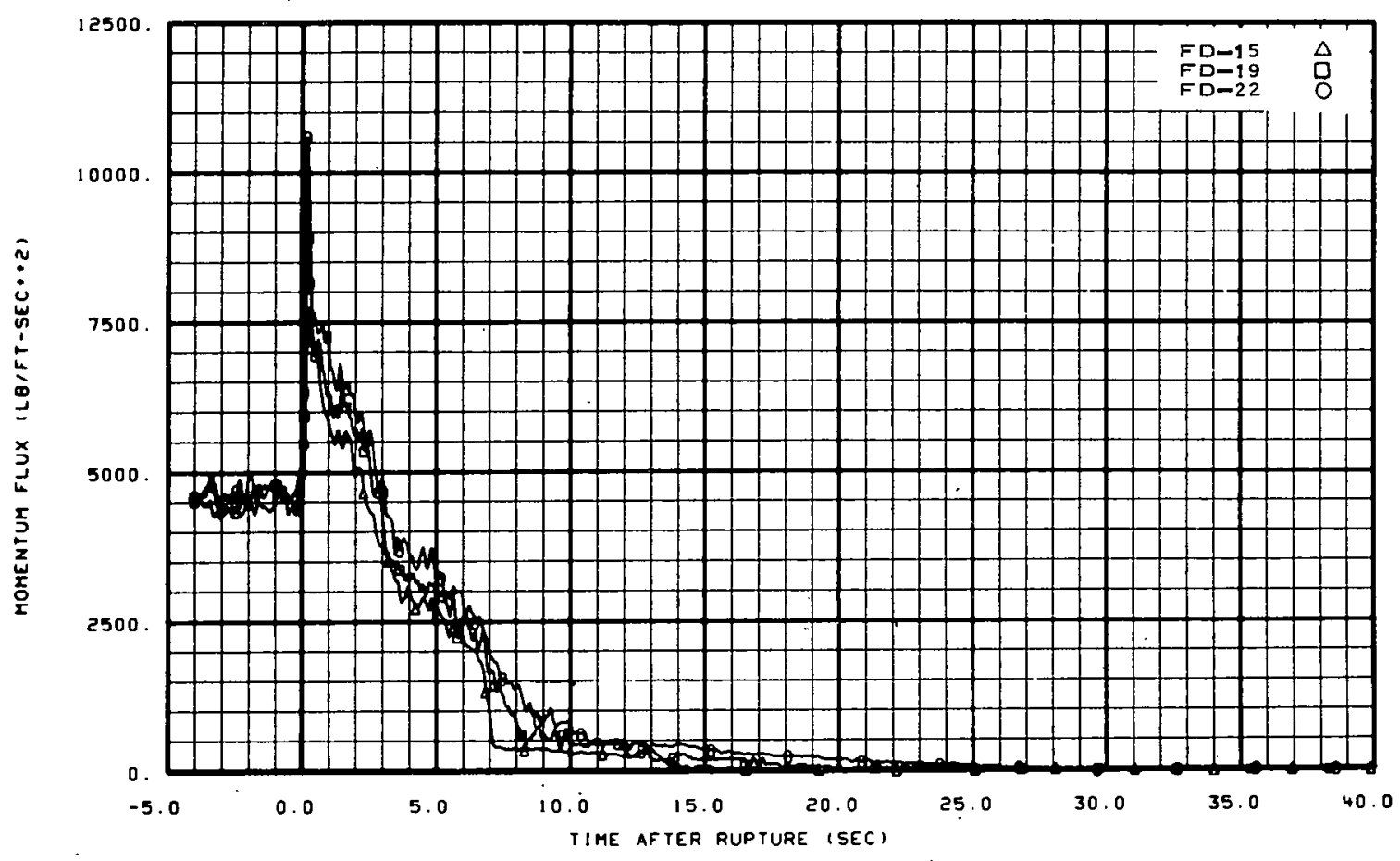

Fig. 49 Momentum flux from drag discs in operating loop cold leg -- Test 1002 .

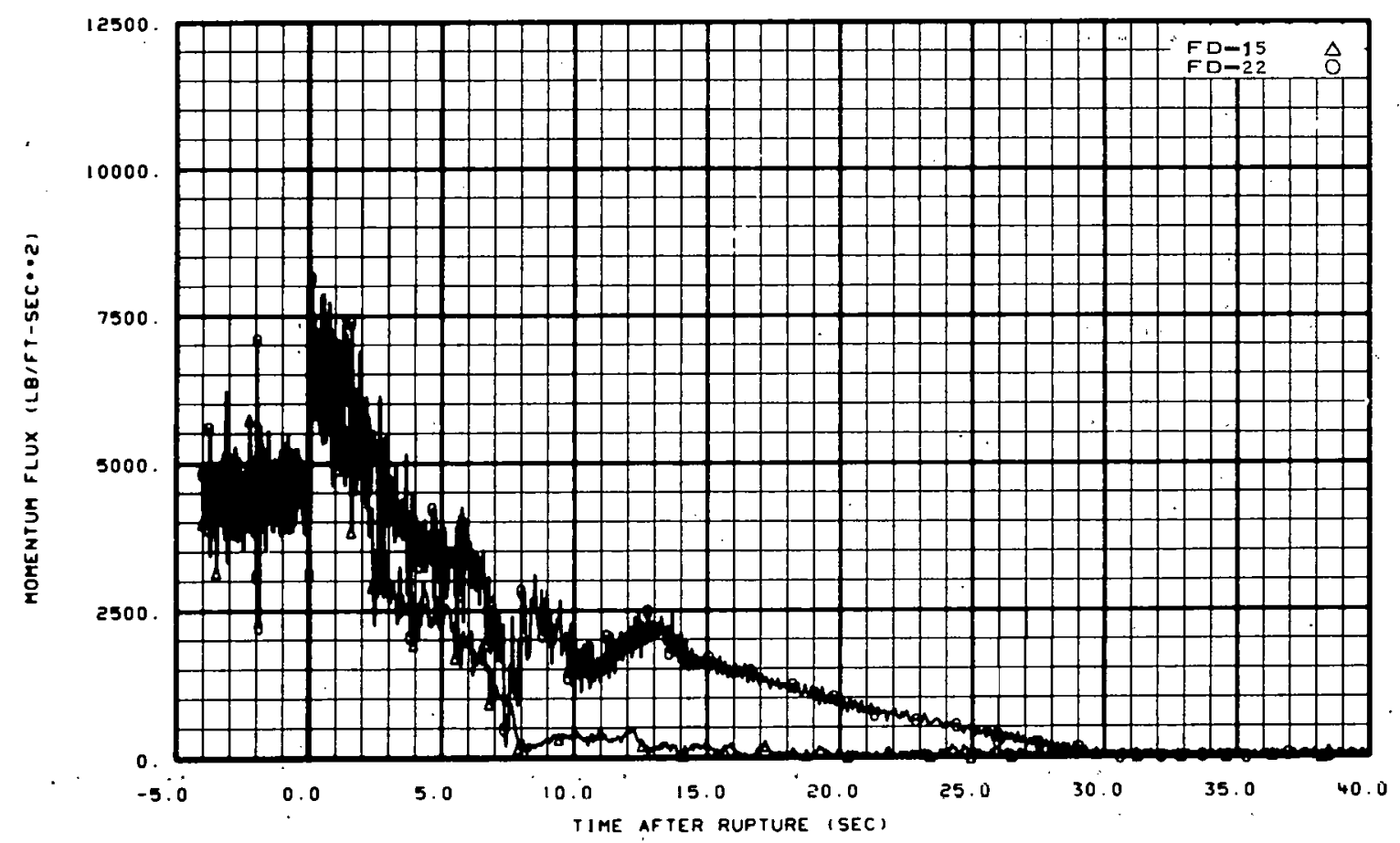

Fig. 50 Momentum flux from drag discs in operating loop cold leg -- Test 1003 (FD-15 and FD-22). 


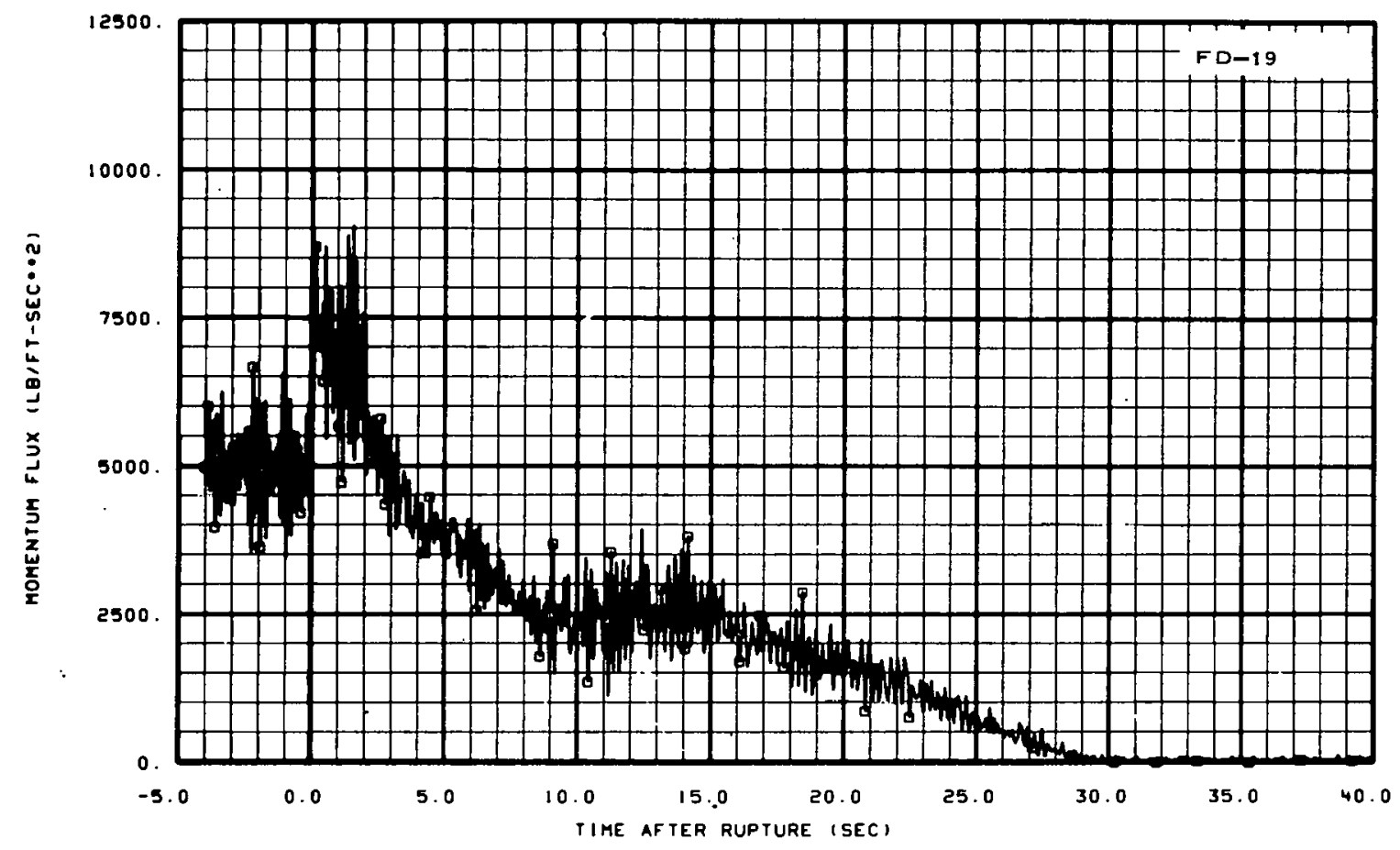

Fig. 51 Momentum flux from drag discs in operating loop cold leg -- Test 1003 (FD-19).

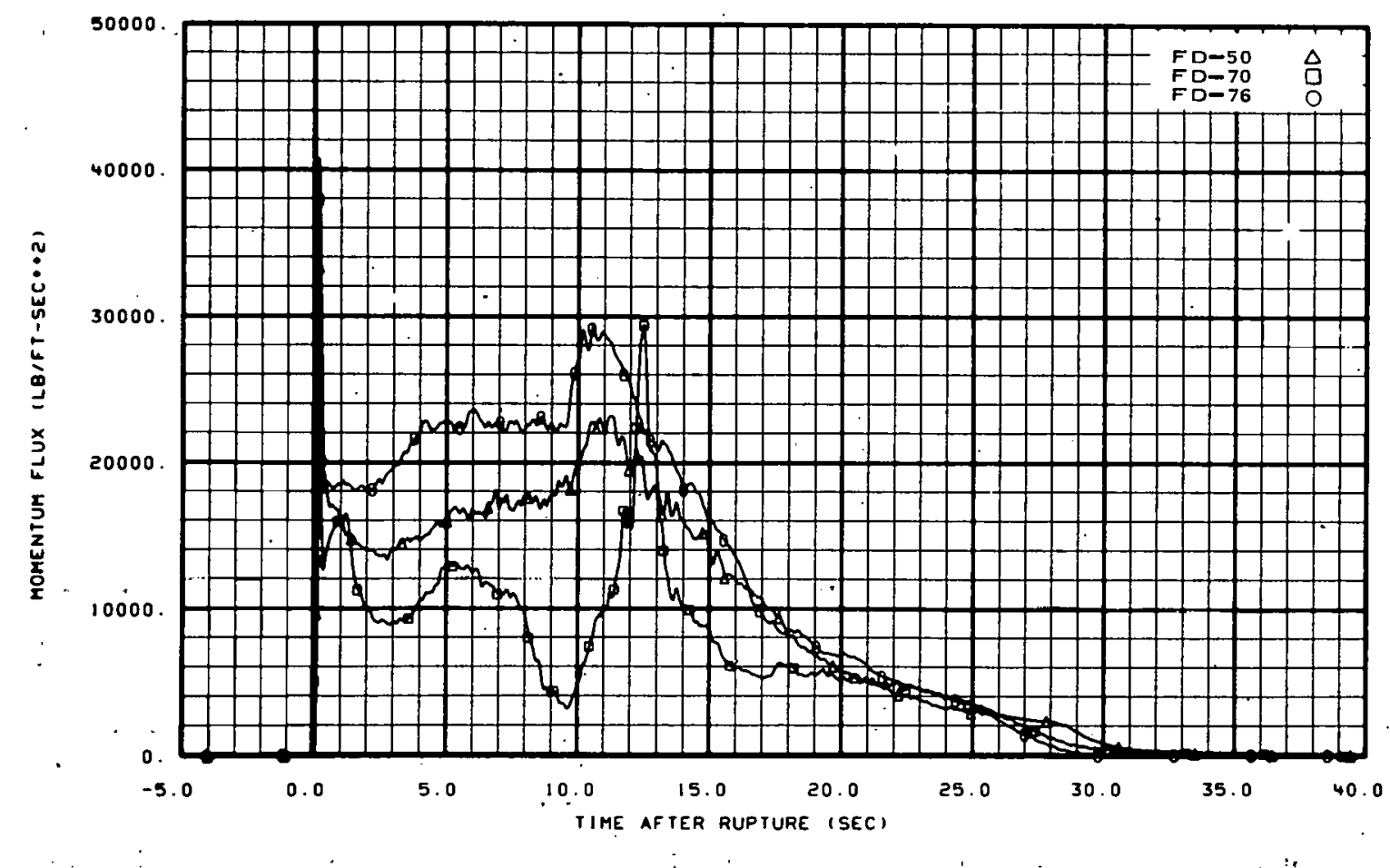

Fig. 52 Momentum flux from drag discs in blowdown loop:- Test 1001. 


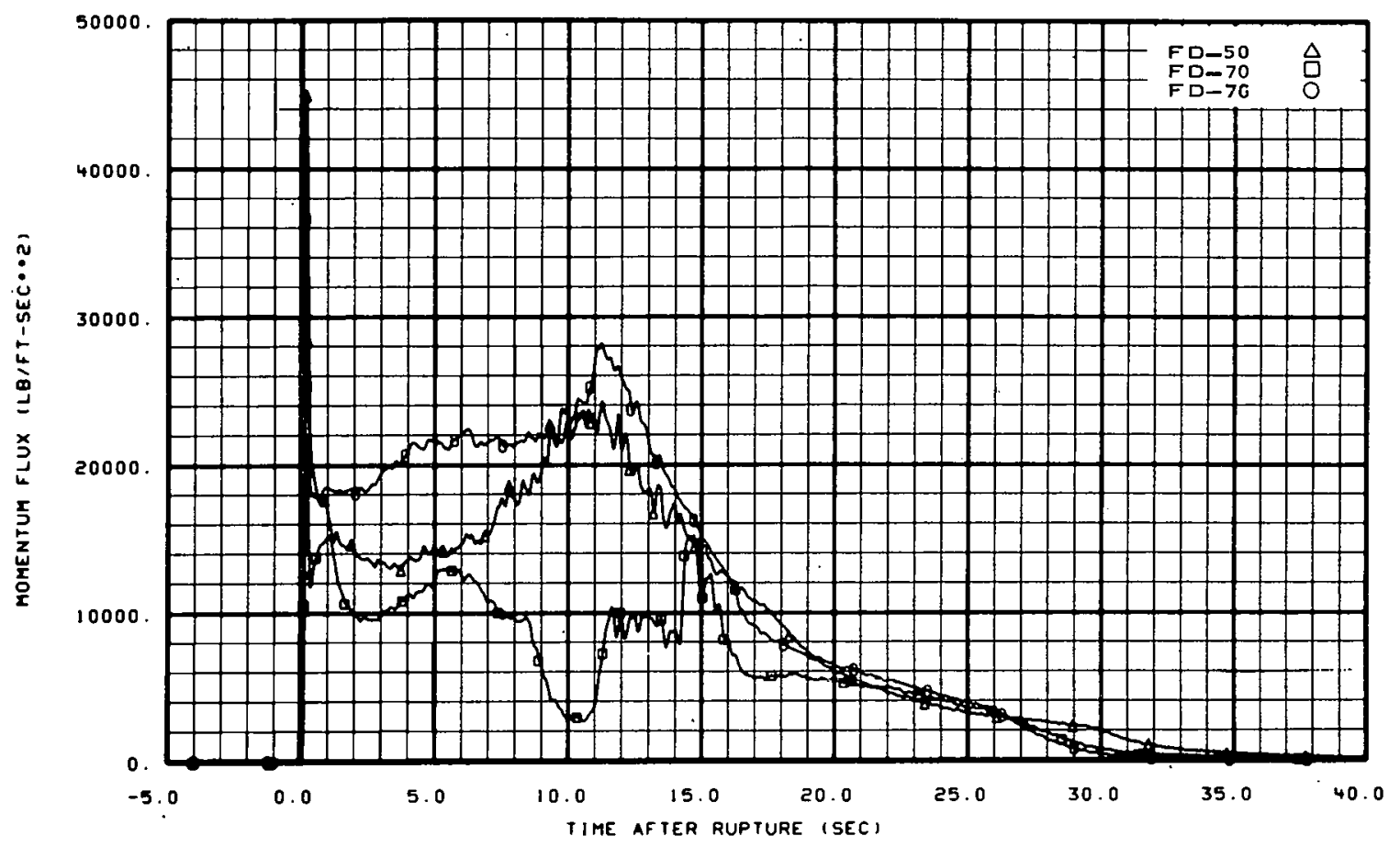

Fig. 53 Momentum flux from drag discs in blowdown loop -- Test 1002.

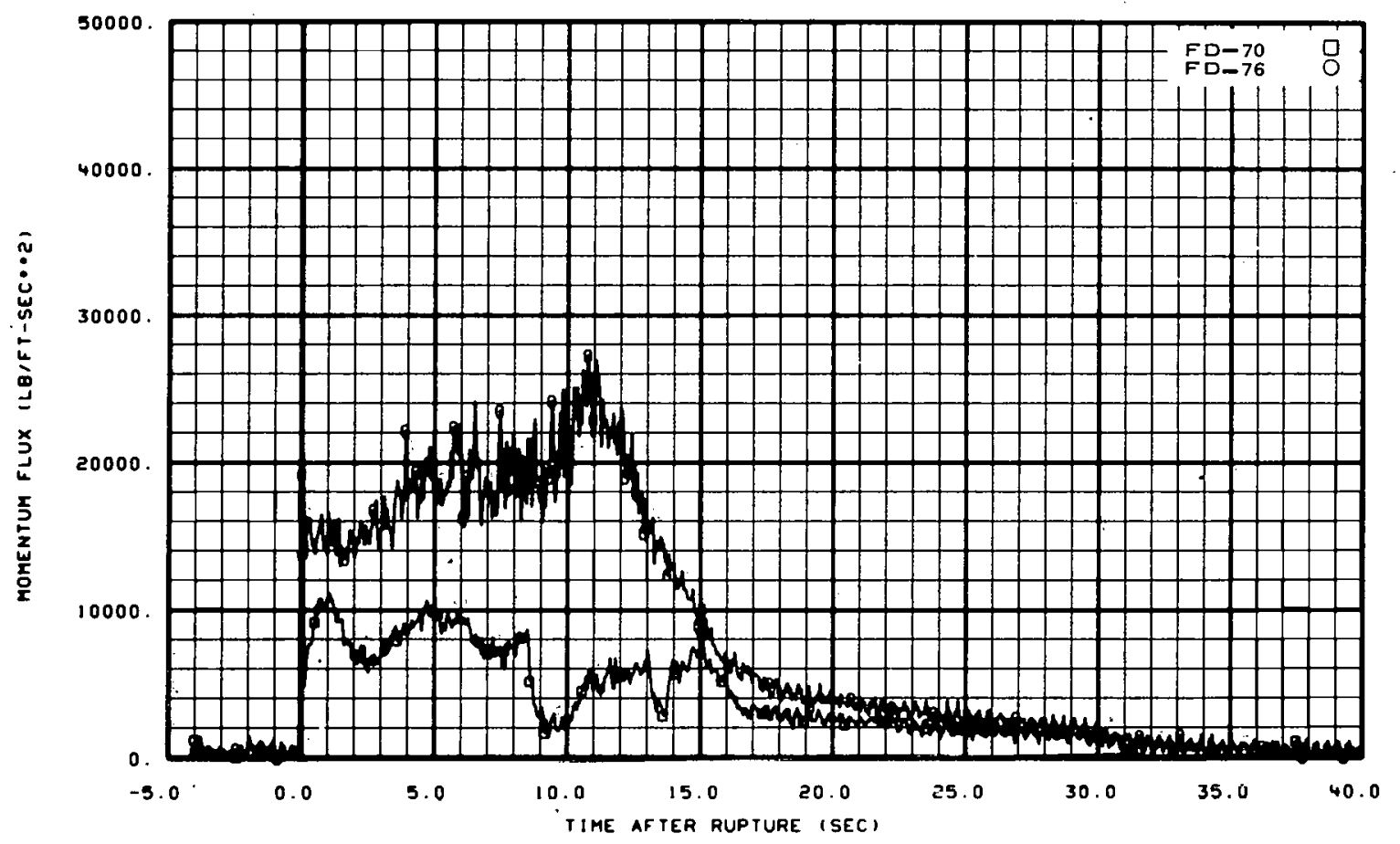

Fig. 54 Momentum flux from drag discs in blowdown loop -- Test 1003 (FD-70 and FD-76). 


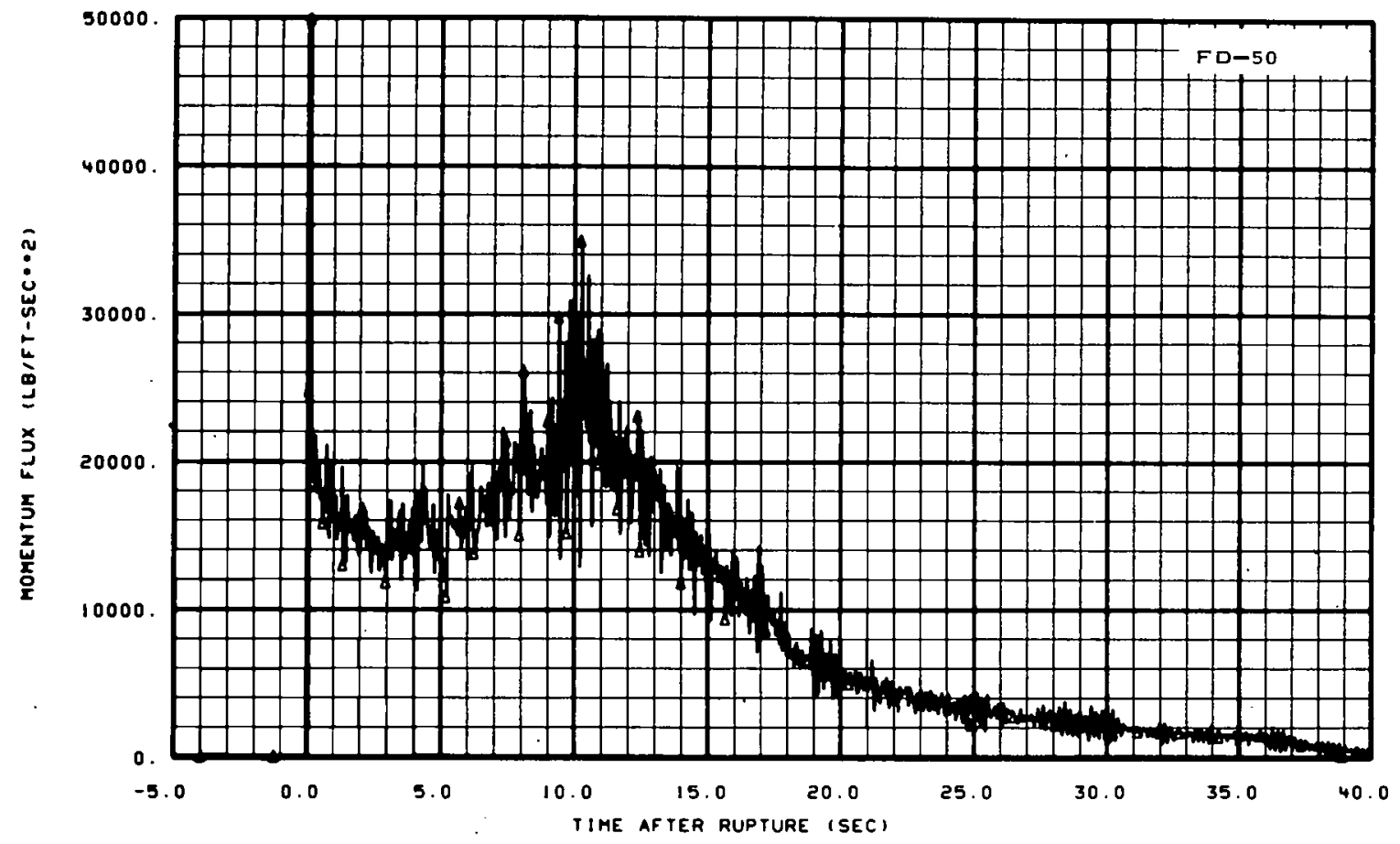

Fig. 55 Momentum flux from drag discs in blowdown loop -- Test 1003 (FD-50).

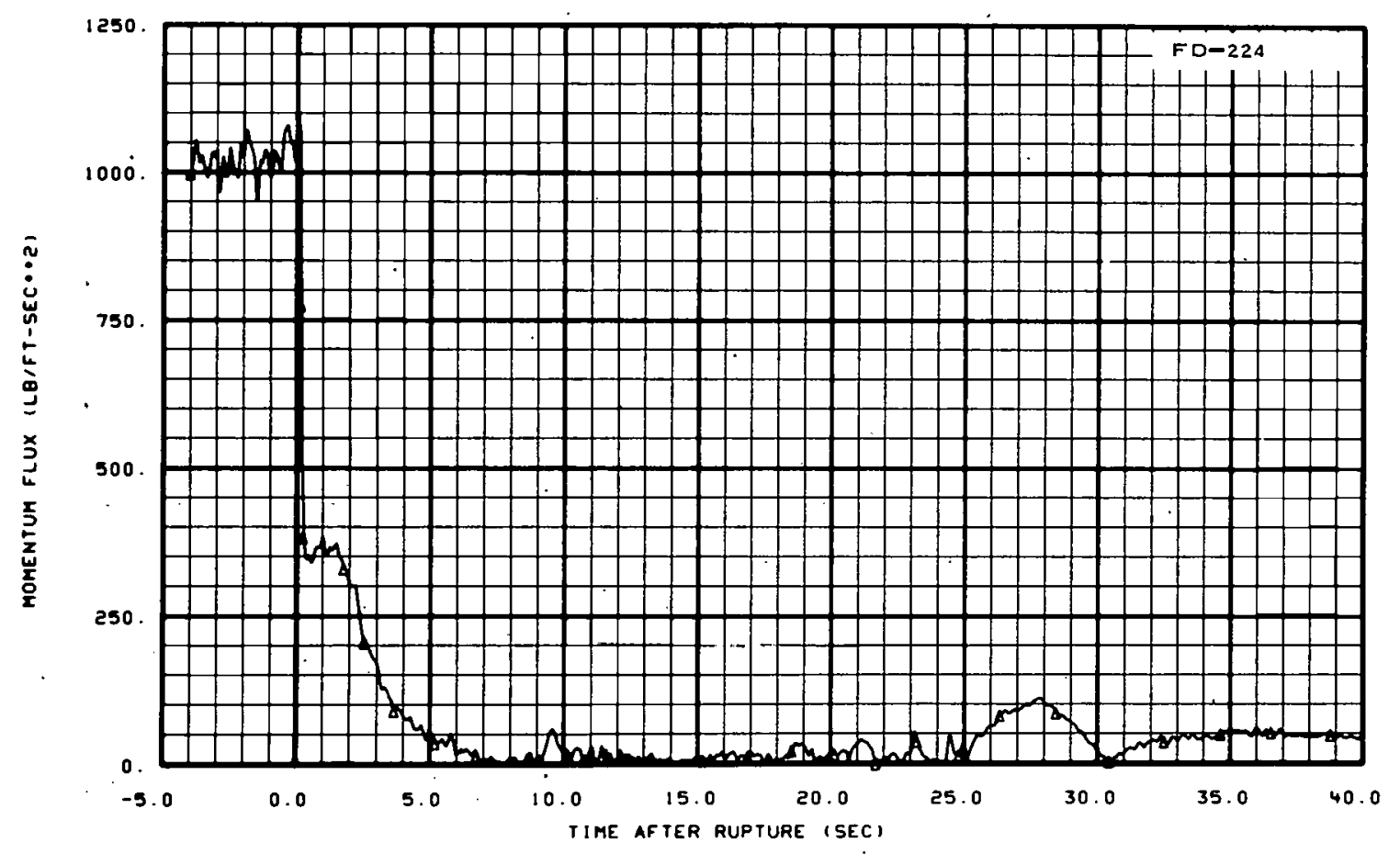

Fig. 56 Momentum flux from drag discs at core barrel inlet -- Test 1001. 


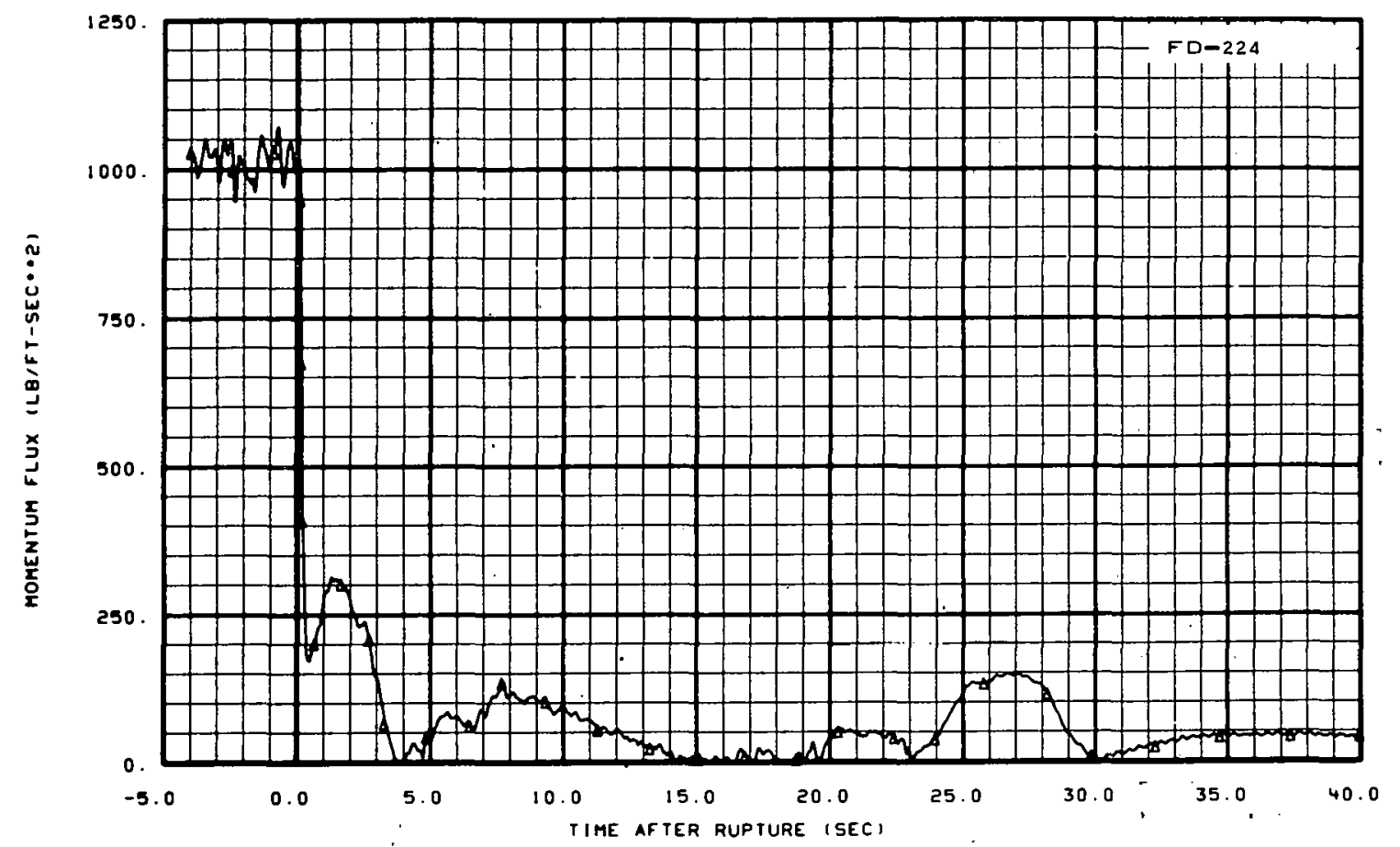

Fig. 57 Momentum flux from drag discs at core barrel inlet -- Test 1002 .

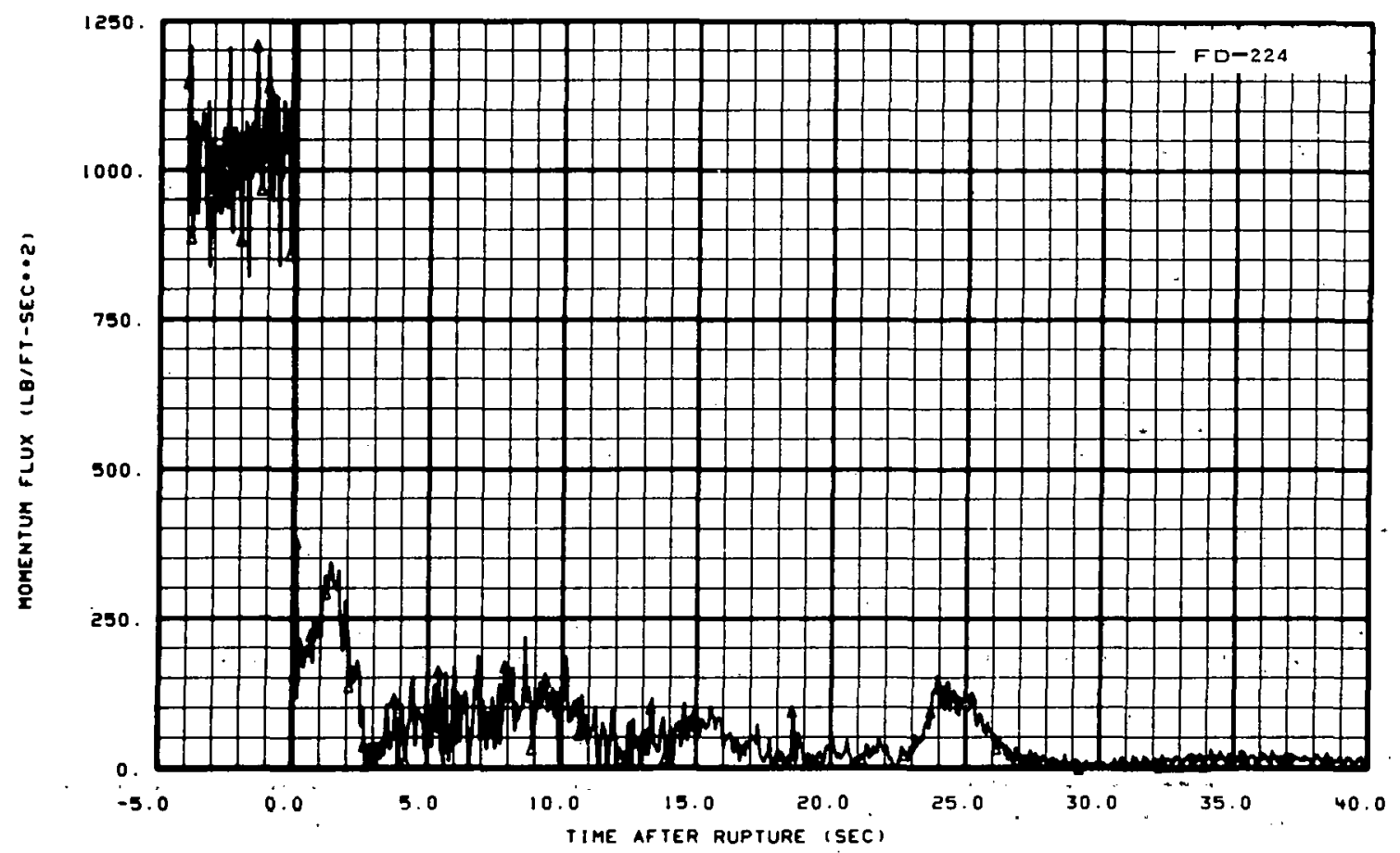

Fig. 58 Momentum flux from drag discs at core barrel inlet -- Test 1003. 


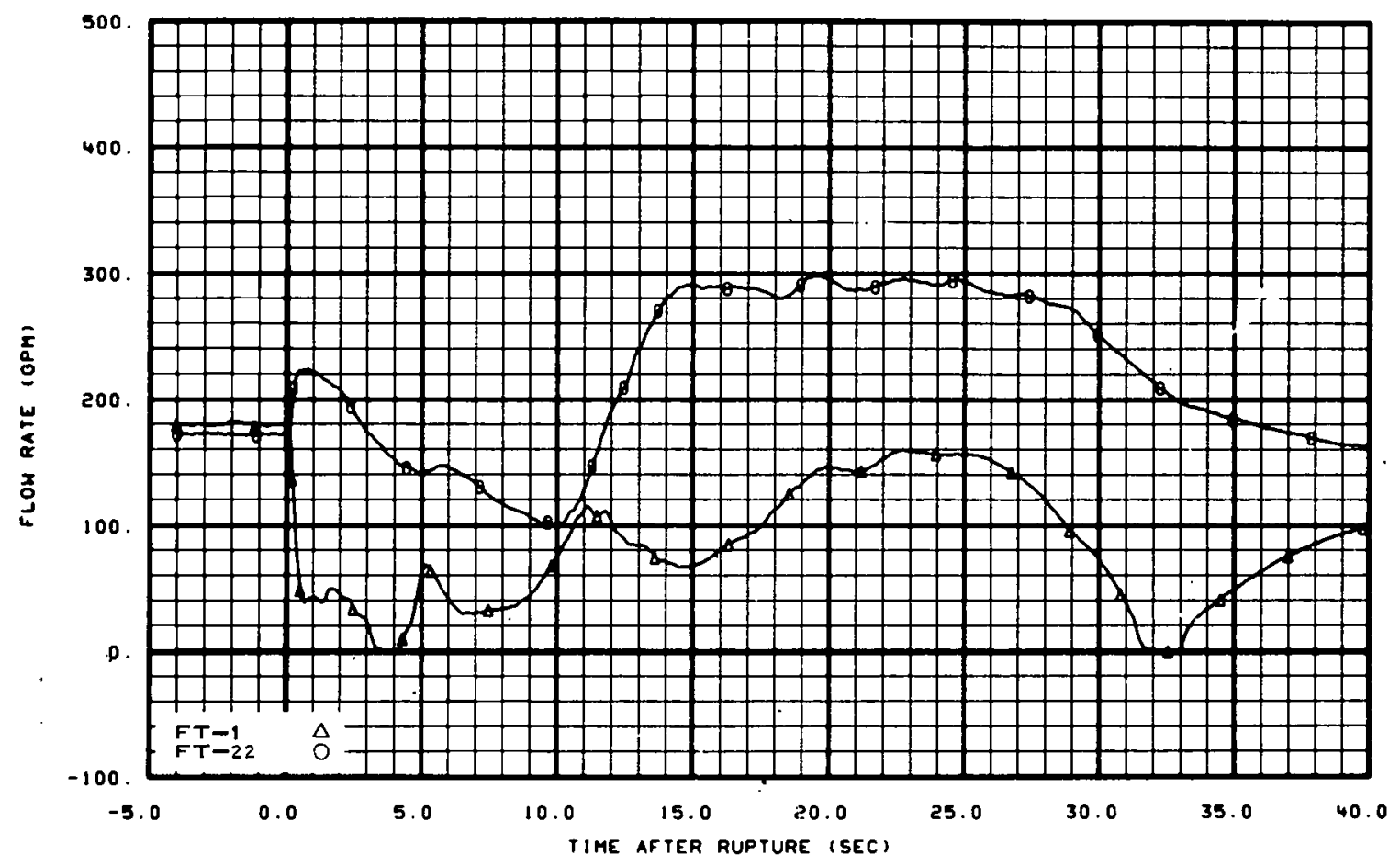

Fig. 59 Volumetric flow rate from turbine meters in operating loop -Test 1001.

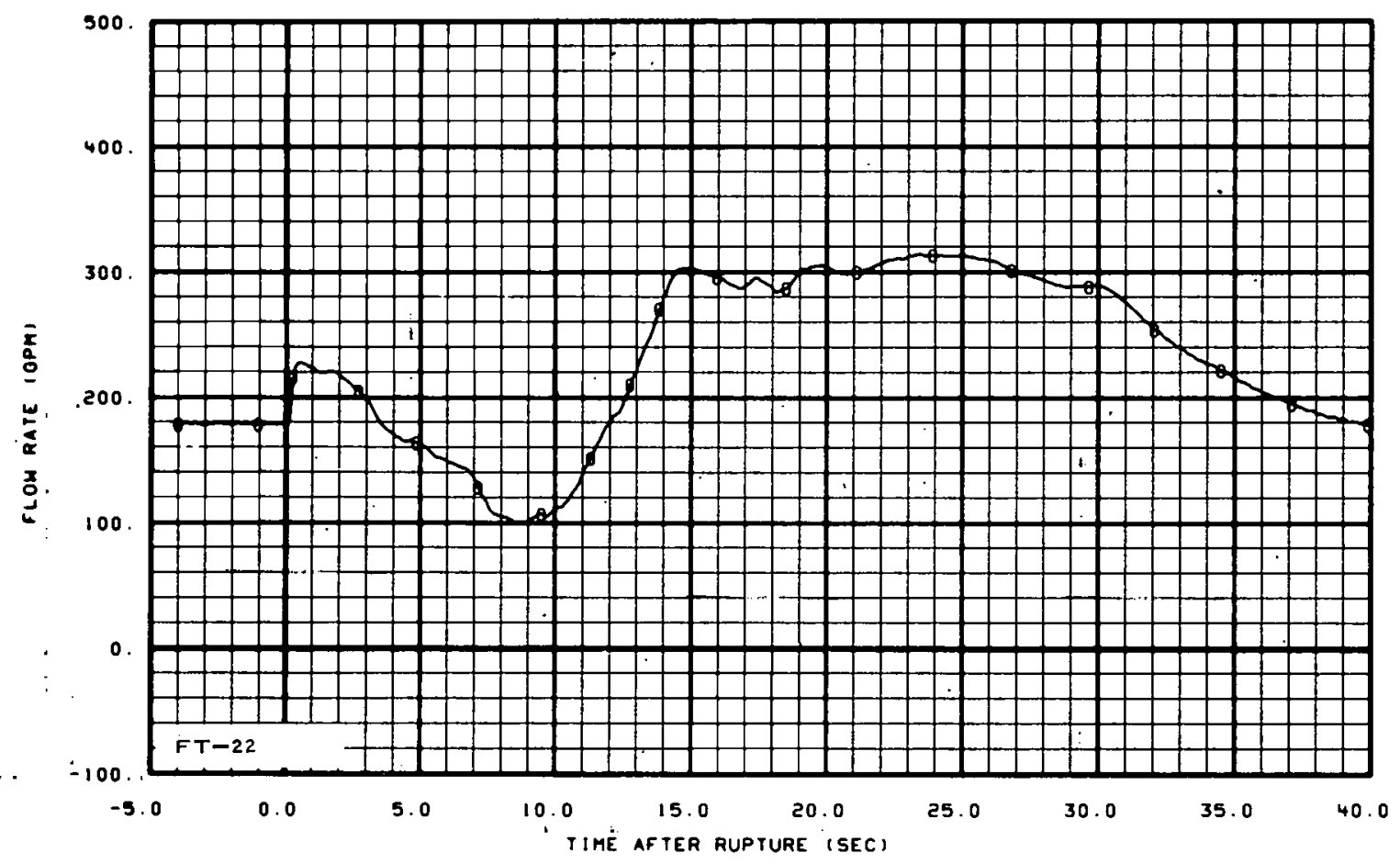

Fig.' 60 Volumetric flow rate from turbine,meters in operating loop :Test 1002 . 


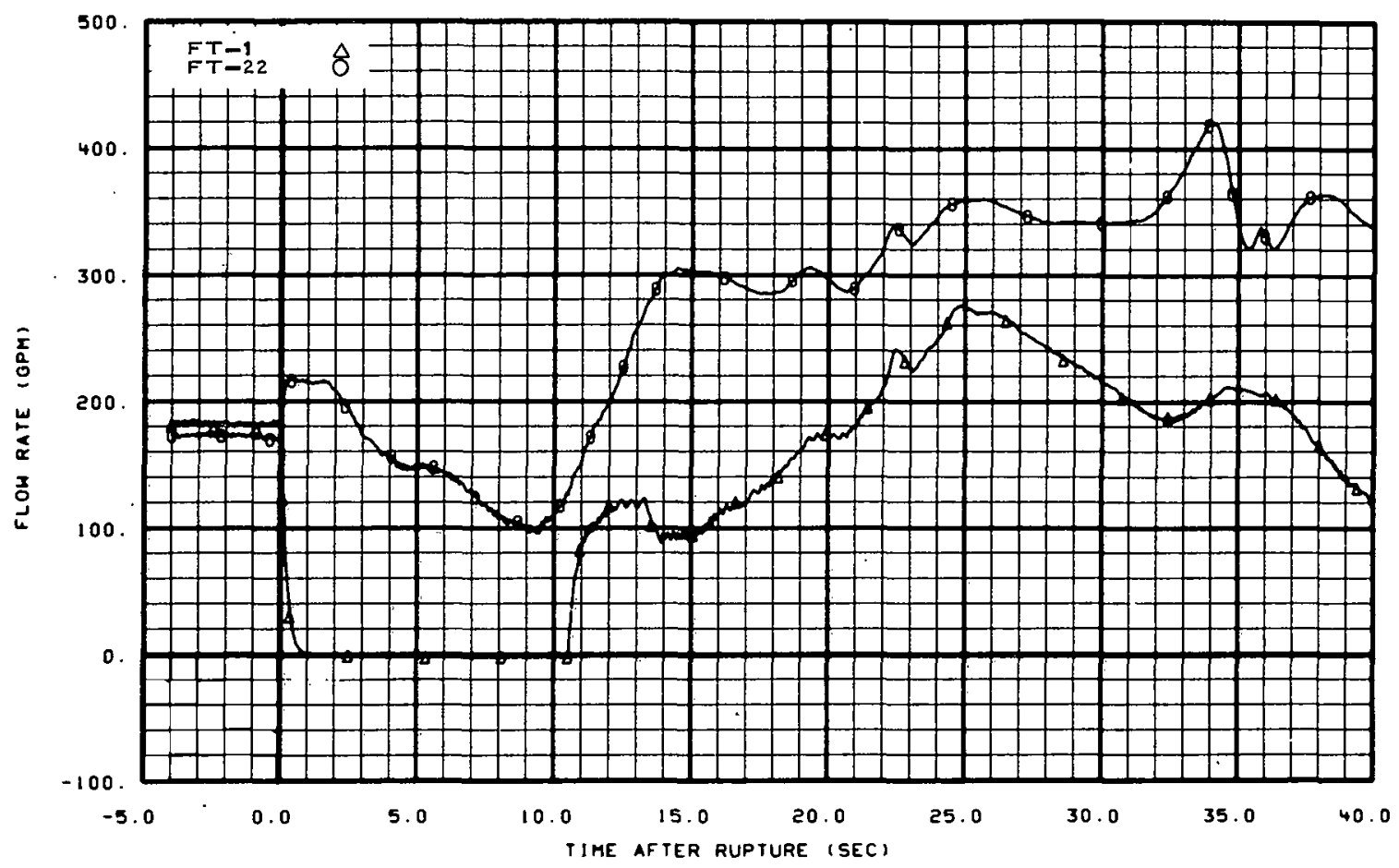

Fig. 61 Volumetric flow rate from turbine meters in operating loop -Test 1003.

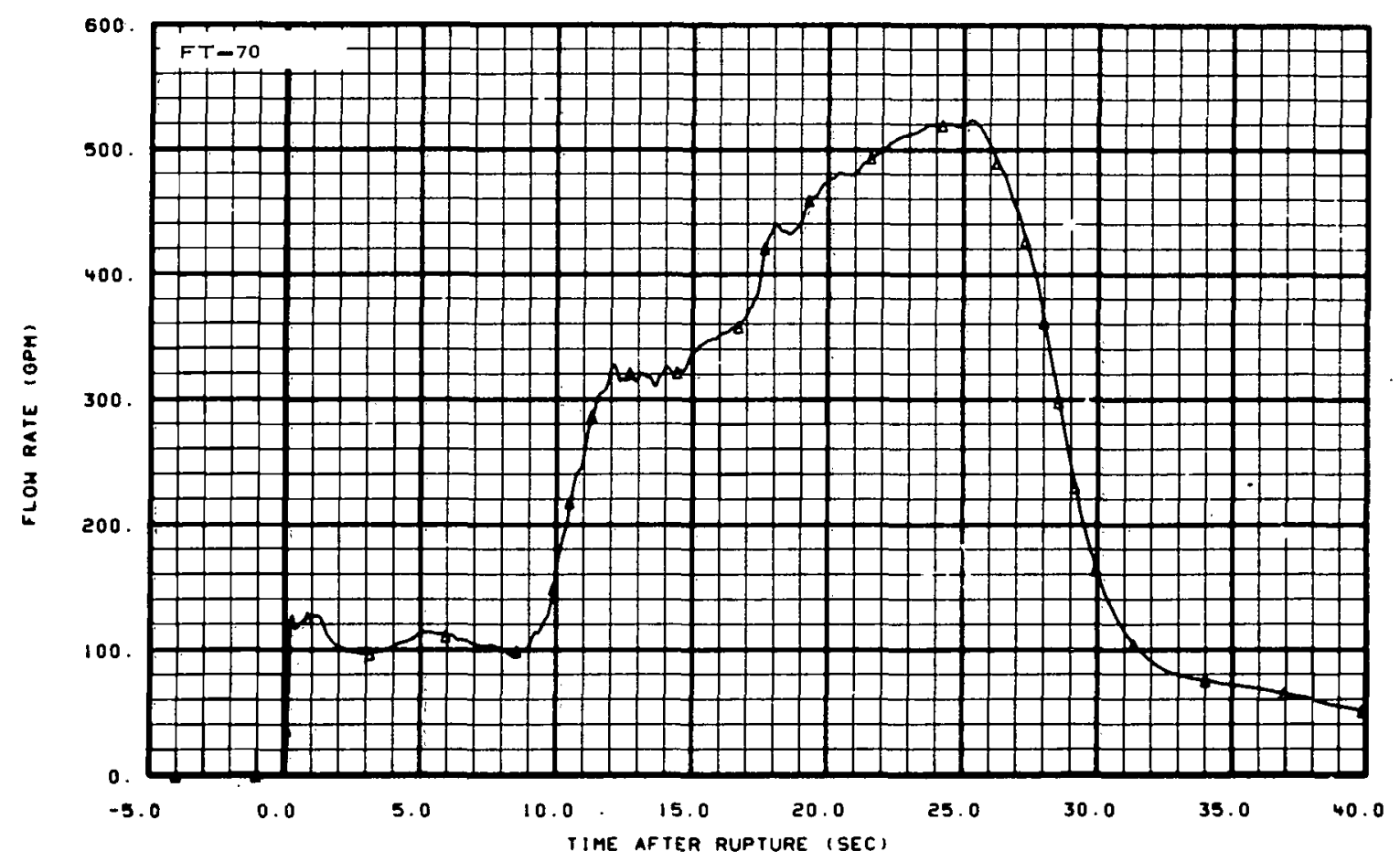

Fig. 62 Volumetric flow rate from turbine meter in blowdown loop hot leg -Test 1001 . 


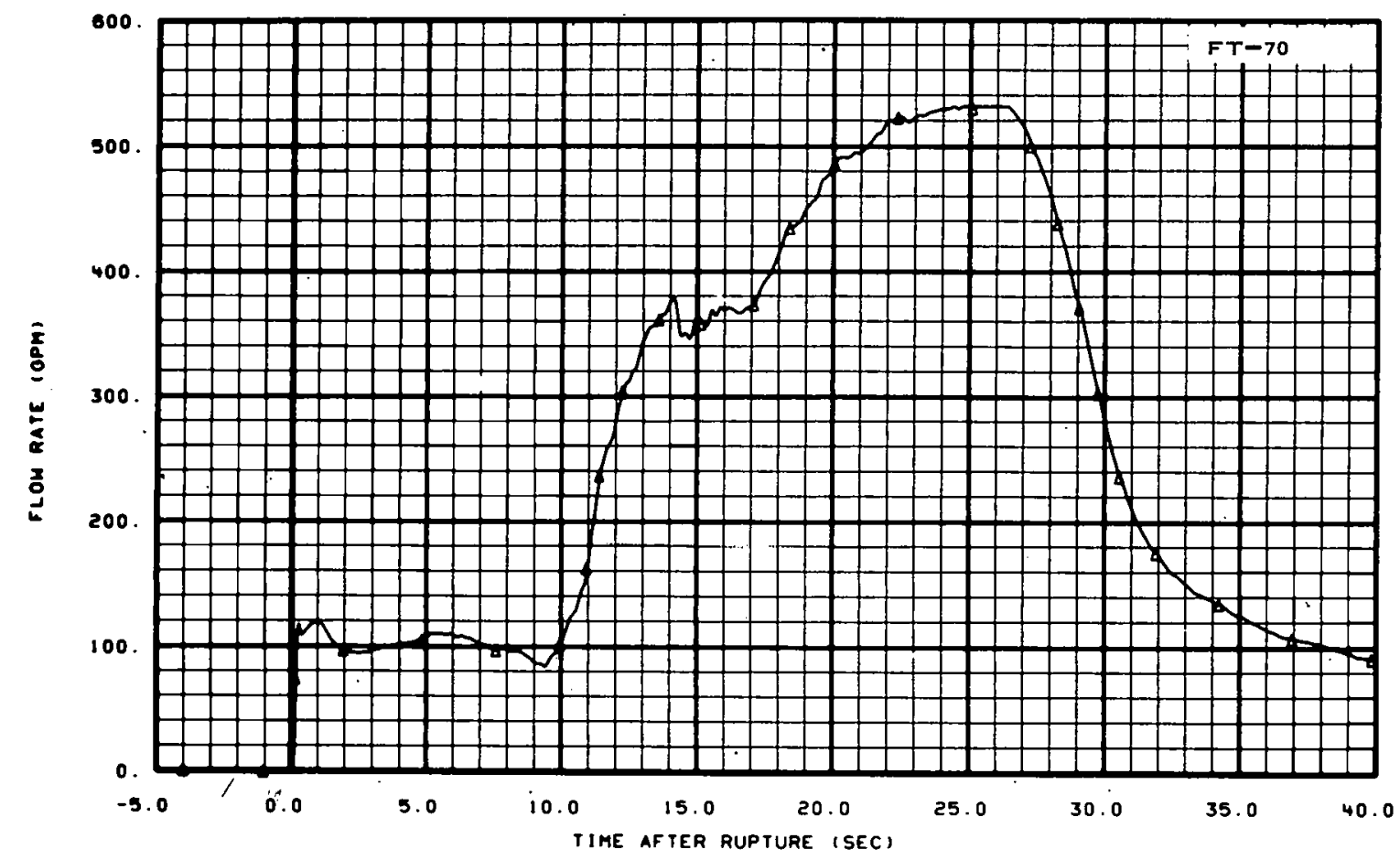

Fig. 63 Volumetric flow rate from turbine meter in blowdown loop hot leg -Test 1002 .

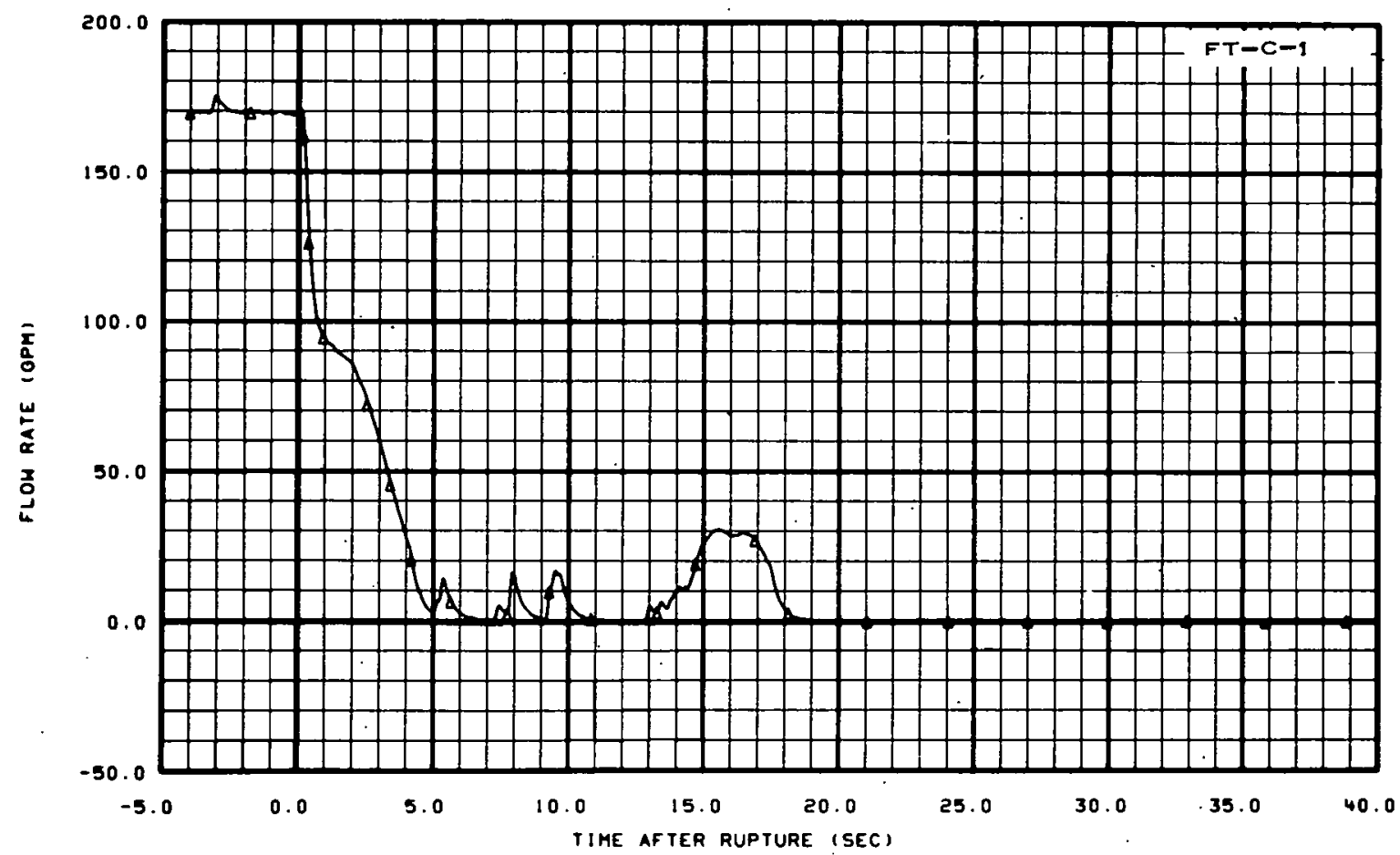

Fig. 64 Volumetric flow rate from turbine meter at core barrel inlet -Test 1001 . 


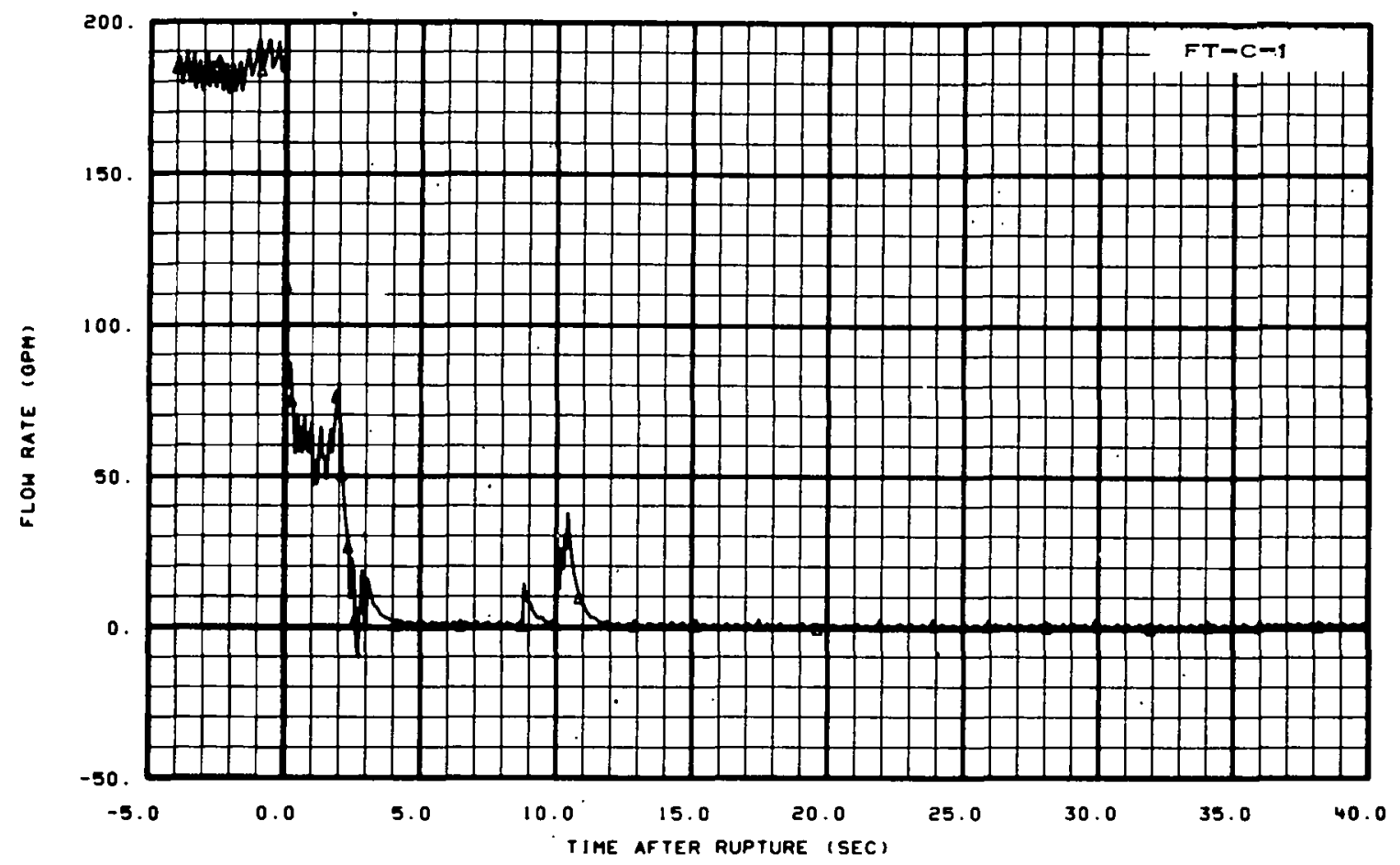

Fig. 65 Volumetric flow rate from turbine meter at core barrel inlet -Test 1003.

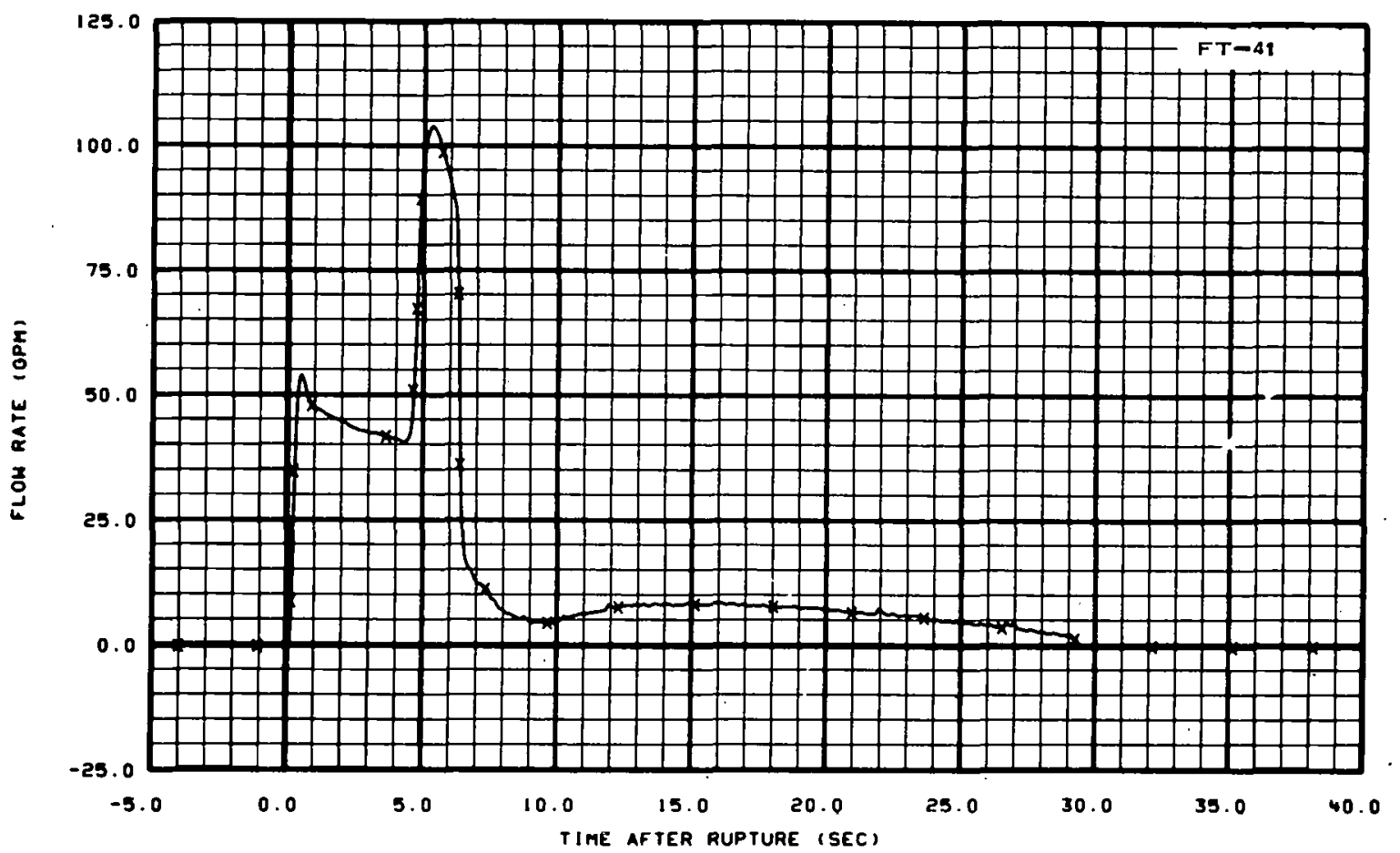

Fig. 66 Volumetric flow rate from turbine meter at pressurizer outlet -Test 1001 . 


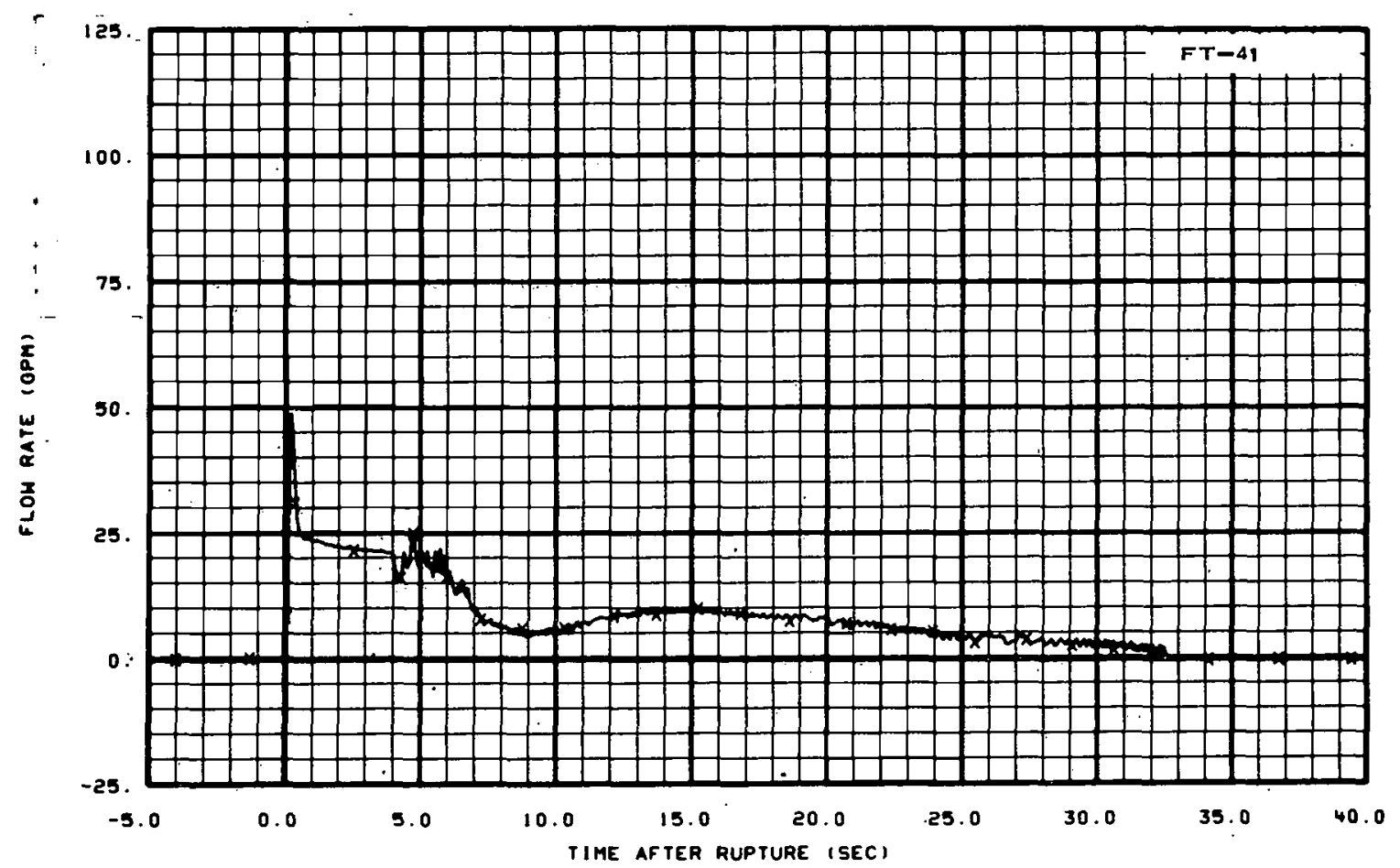

Fig. 67 Volumetric flow rate from turbine meter at pressurizer outlet -Test 1003.

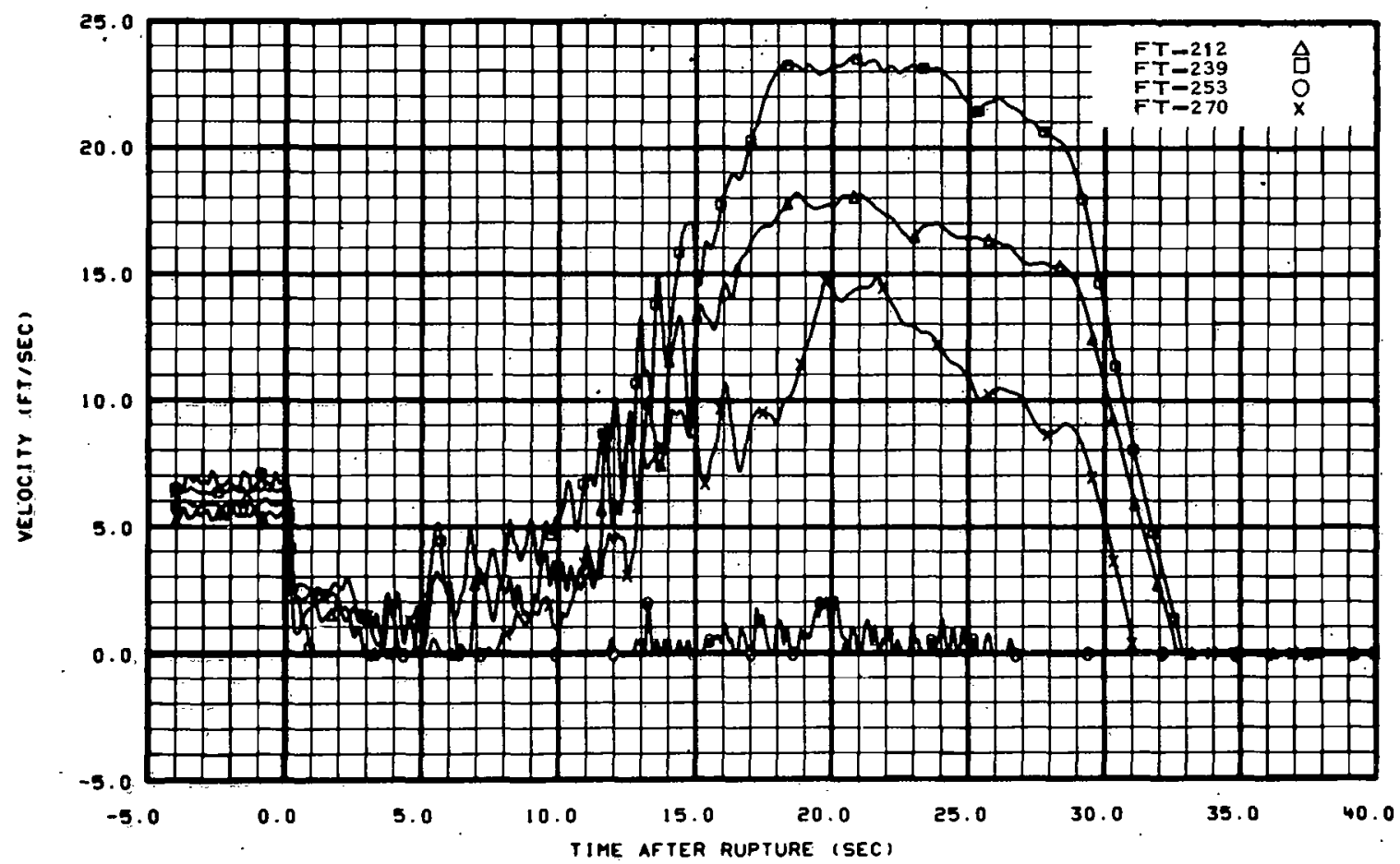

Fig. 68 Fluid velocity from turbine meters in downcomer gap -- Test 1001.: 


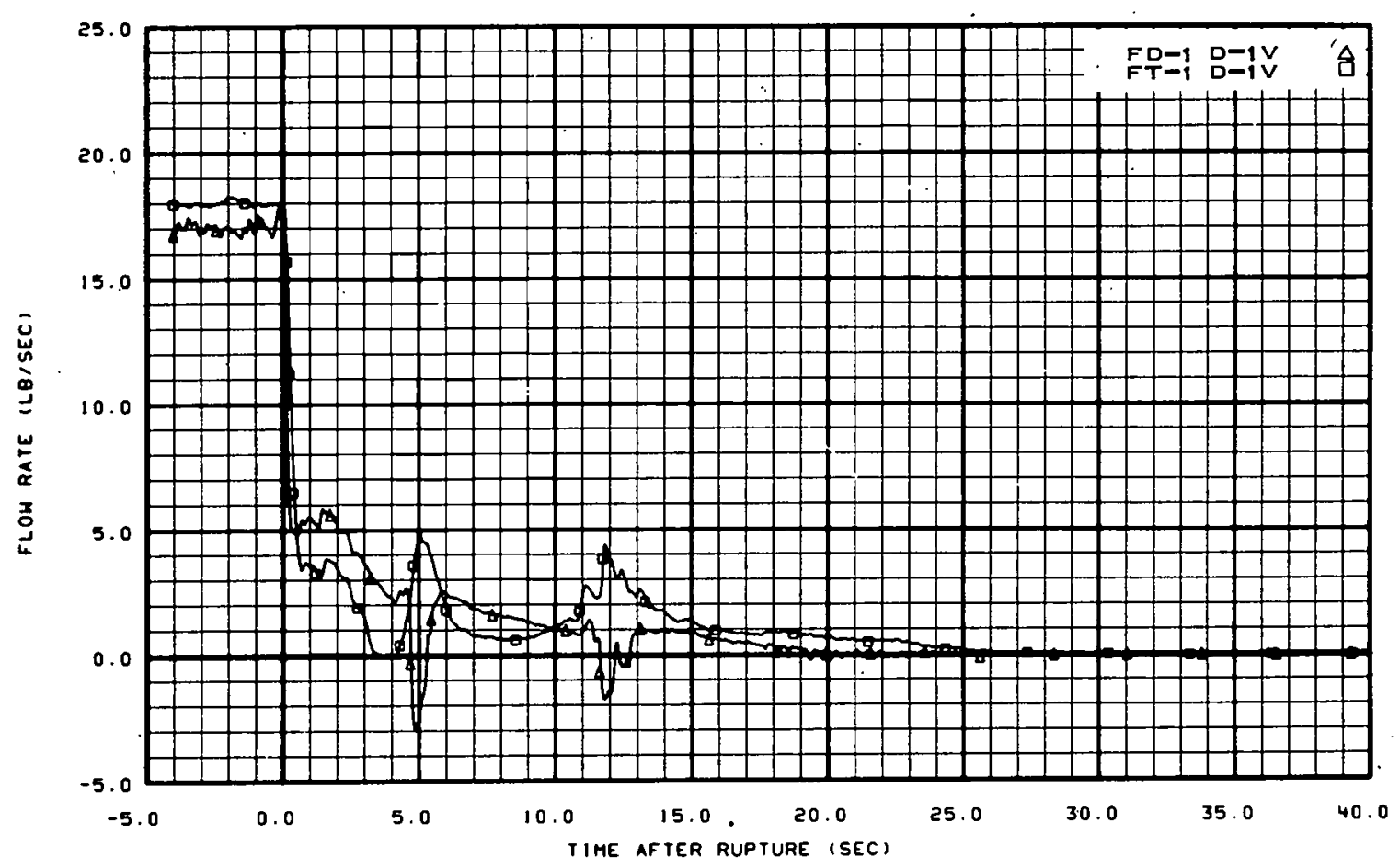

Fig. 69 Mass flow rate in operating loop hot leg Spool 1 -- Test 1001.

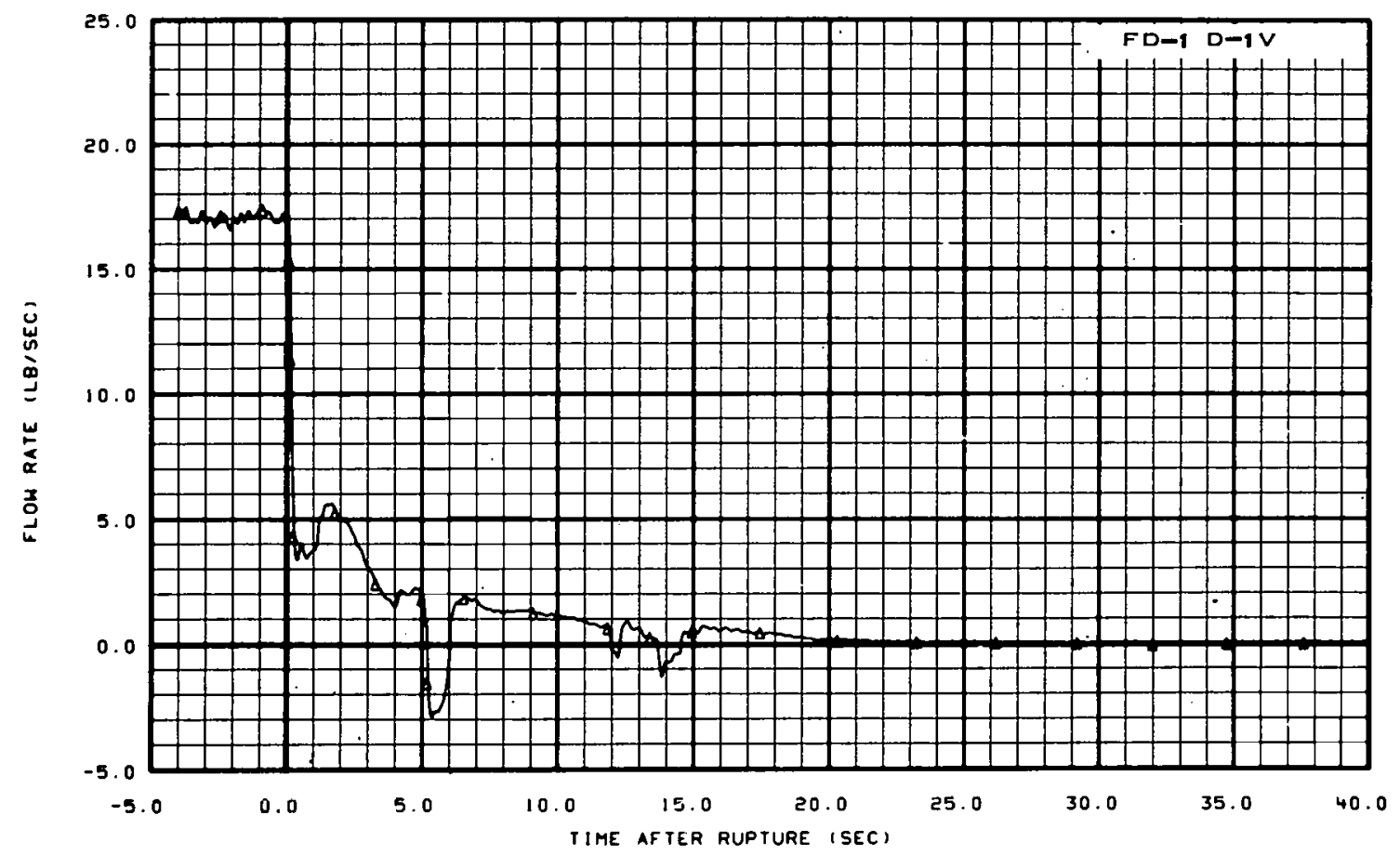

Fig. 70 Mass flow rate in operating loop hot leg Spool 1 -- Test 1002. 


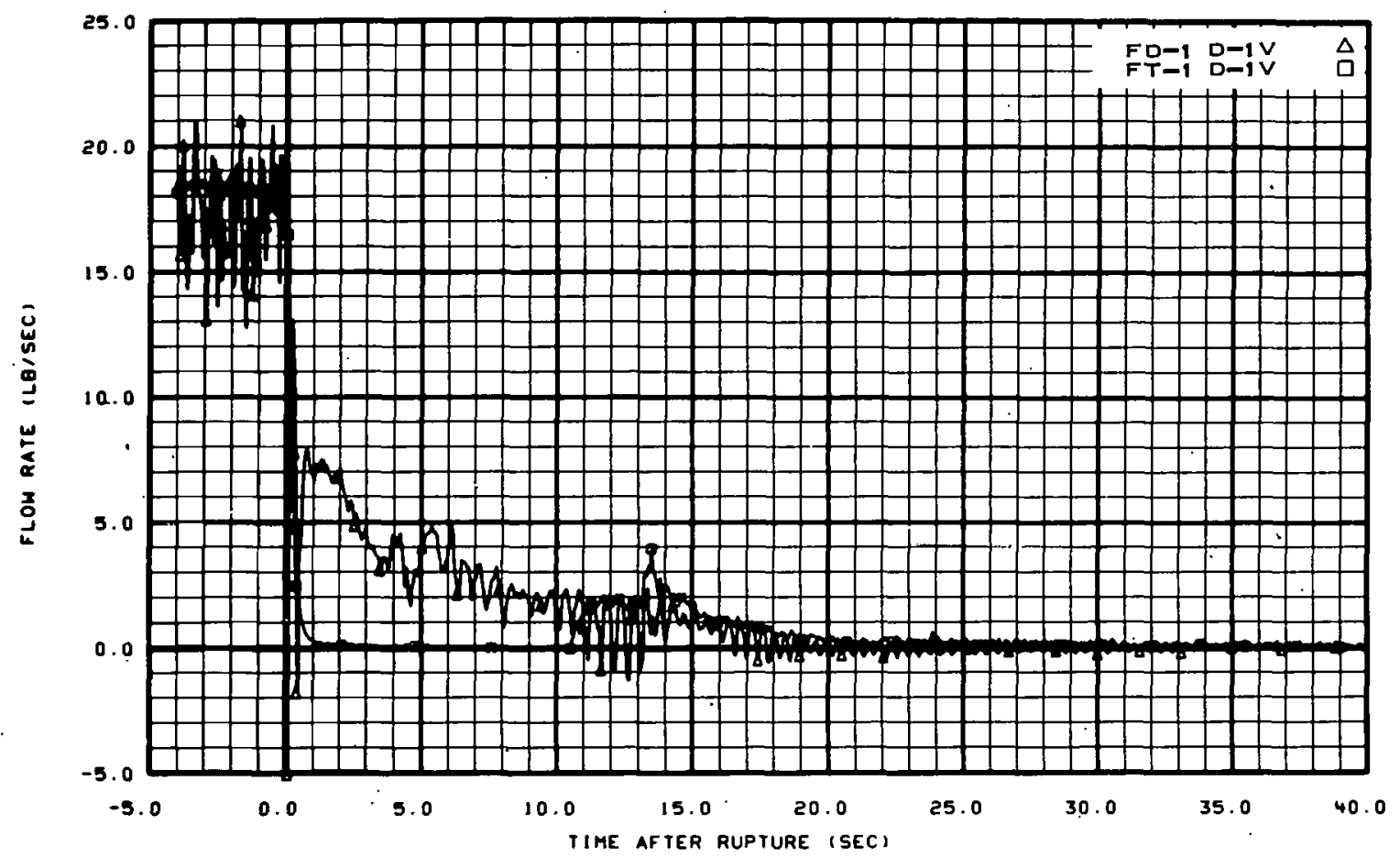

Fig. 71 Mass flow rate in operating loop hot leg Spool 1 -- Test 1003.

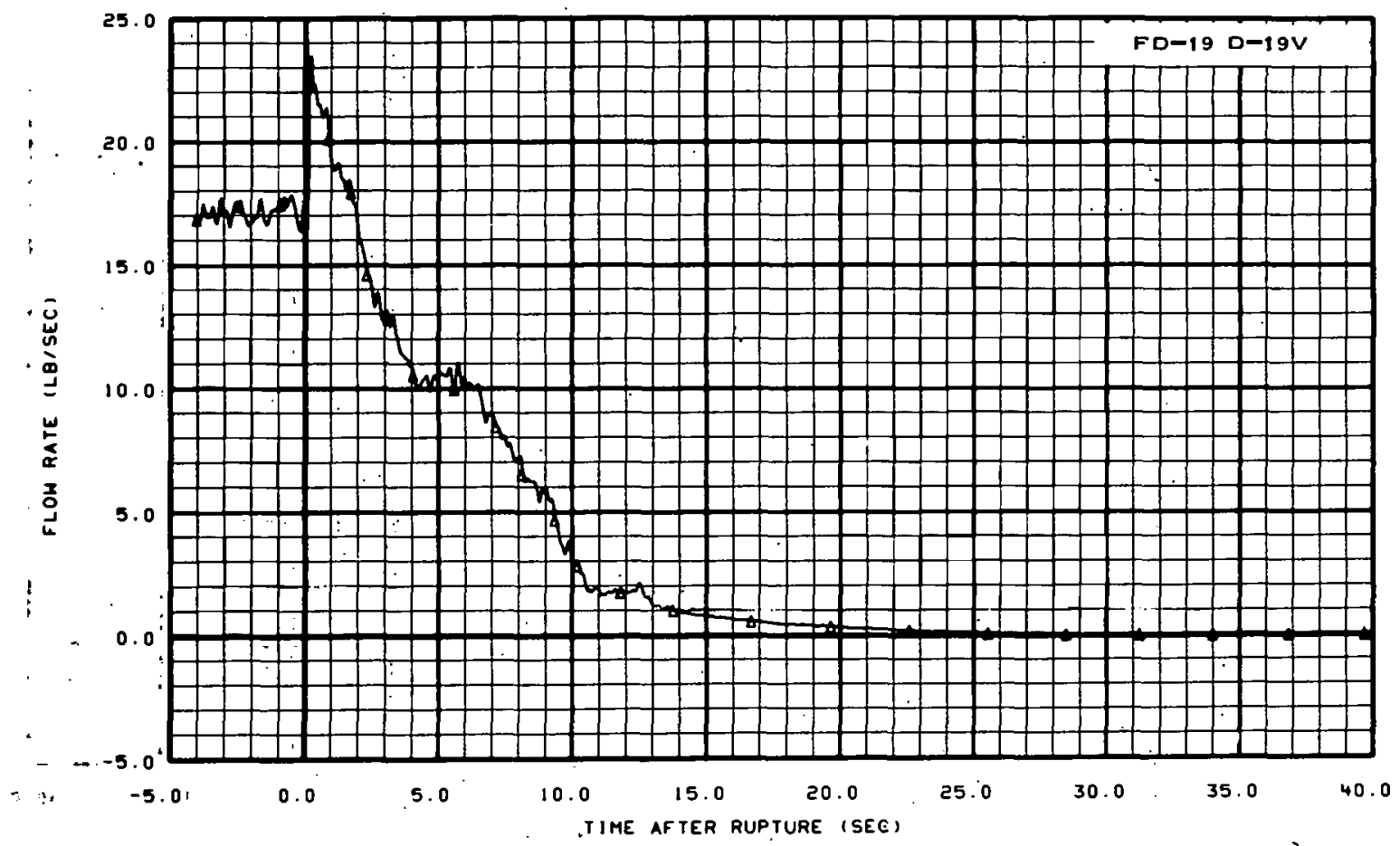

Fig. 72 Mass flow rate in operating loop at pump discharge (Spool 19) -Test' 1001 . 


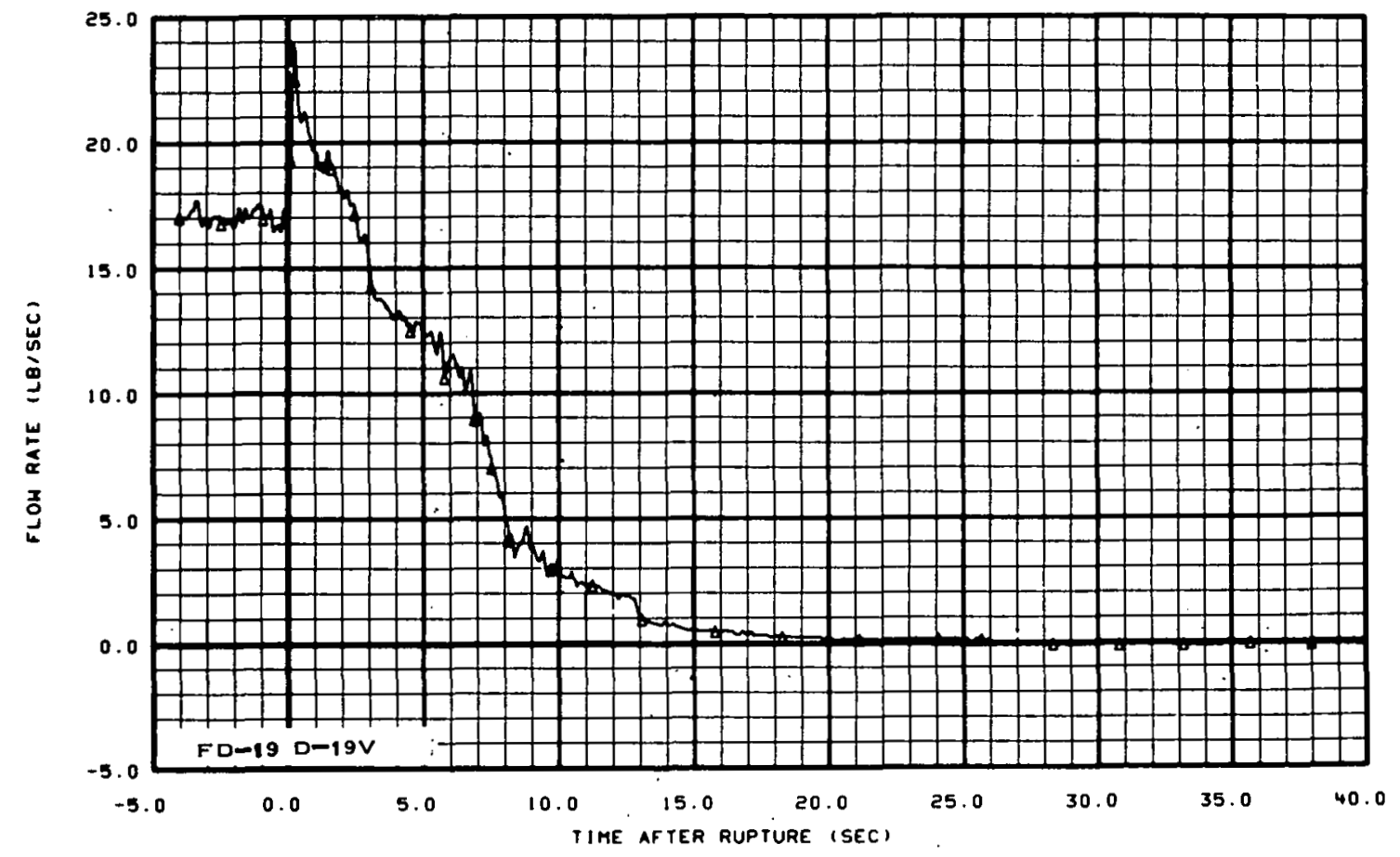

Fig. 73 Mass flow rate in operating loop at pump discharge (Spool 19) -Test 1002 .

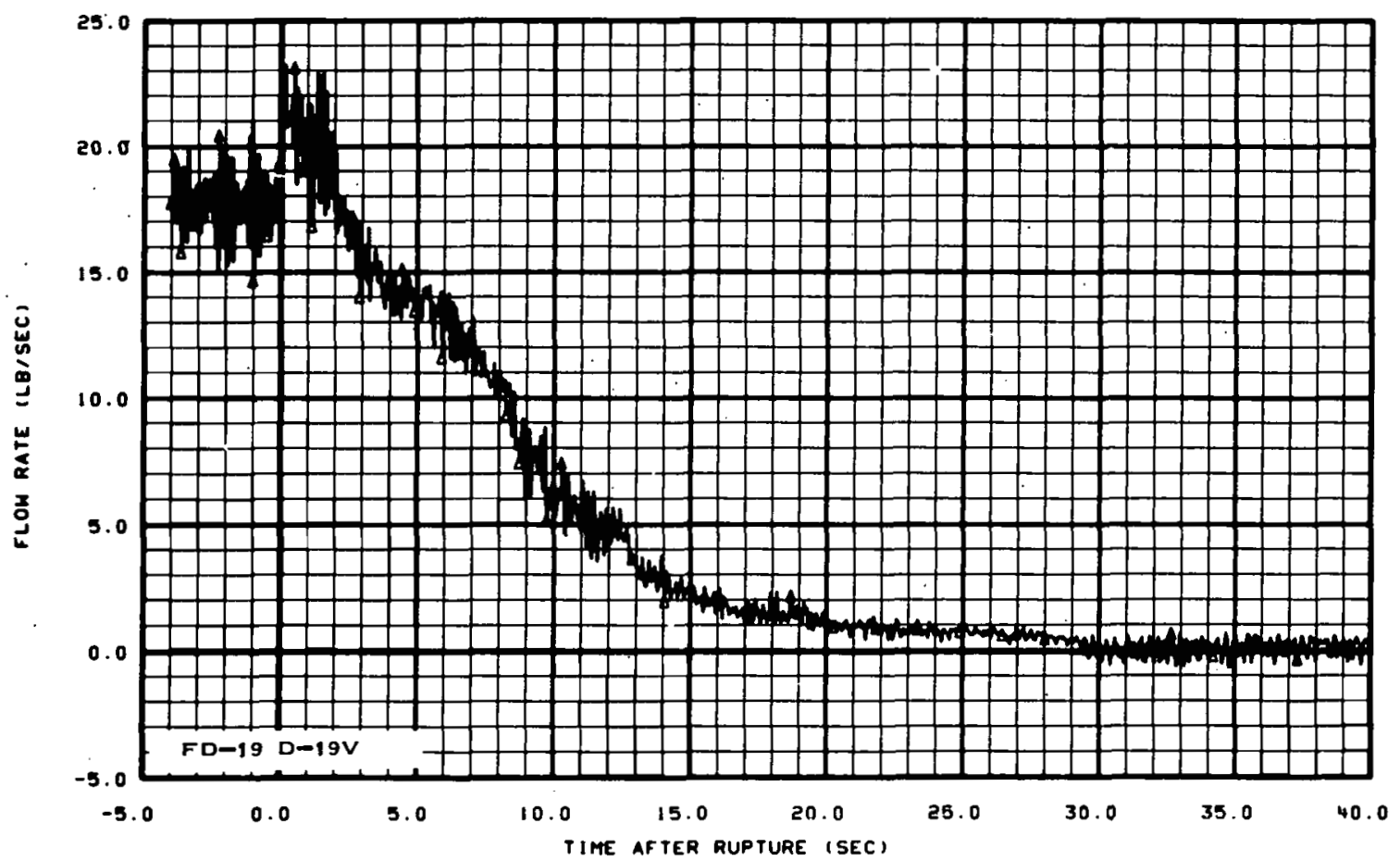

Fig. 74 Mass flow rate in operating loop at pump discharge (Spool 19) -Test 1003. 


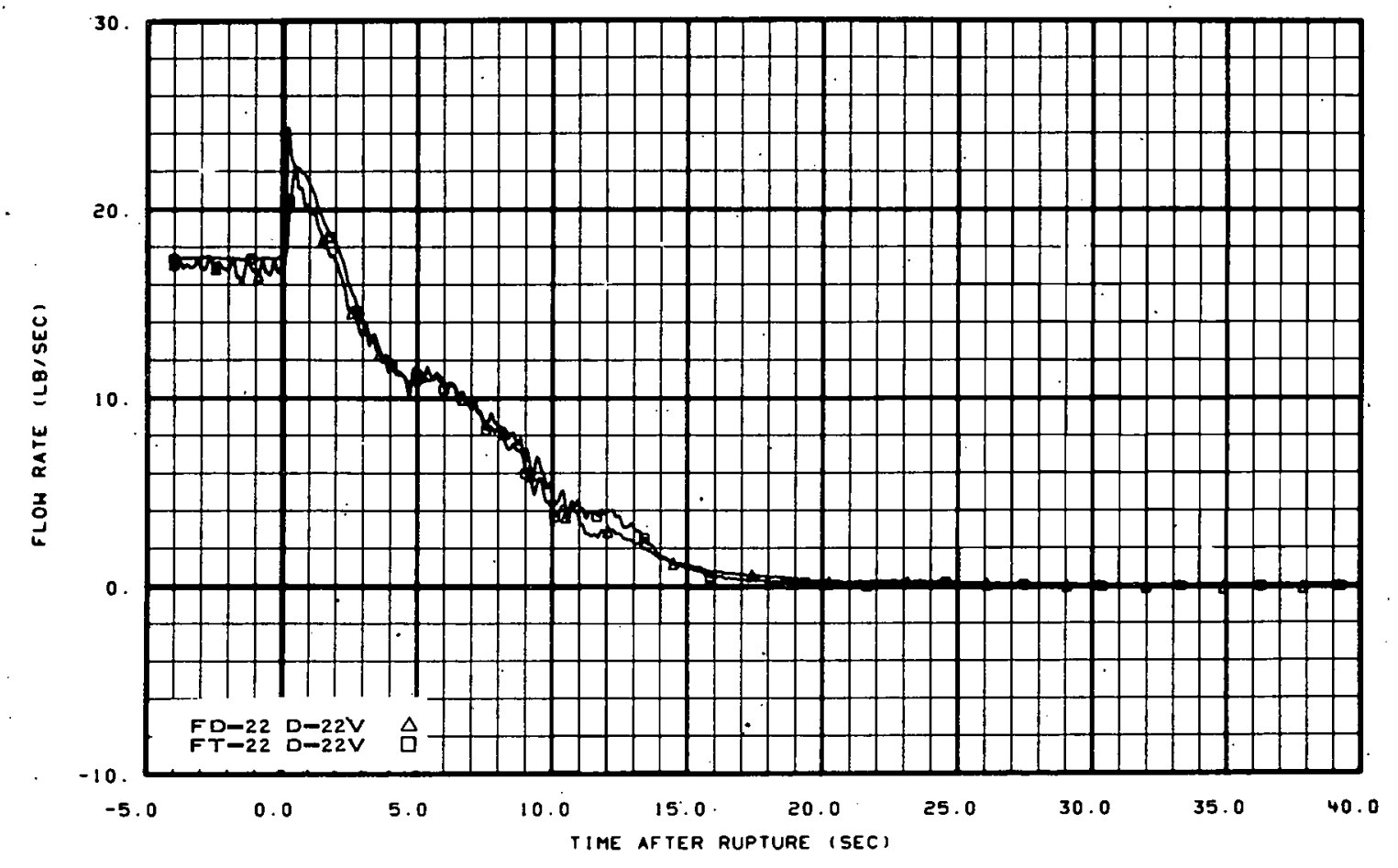

Fig. 75 Mass flow rate in operating loop cold leg Spool 22 -- Test 1001.

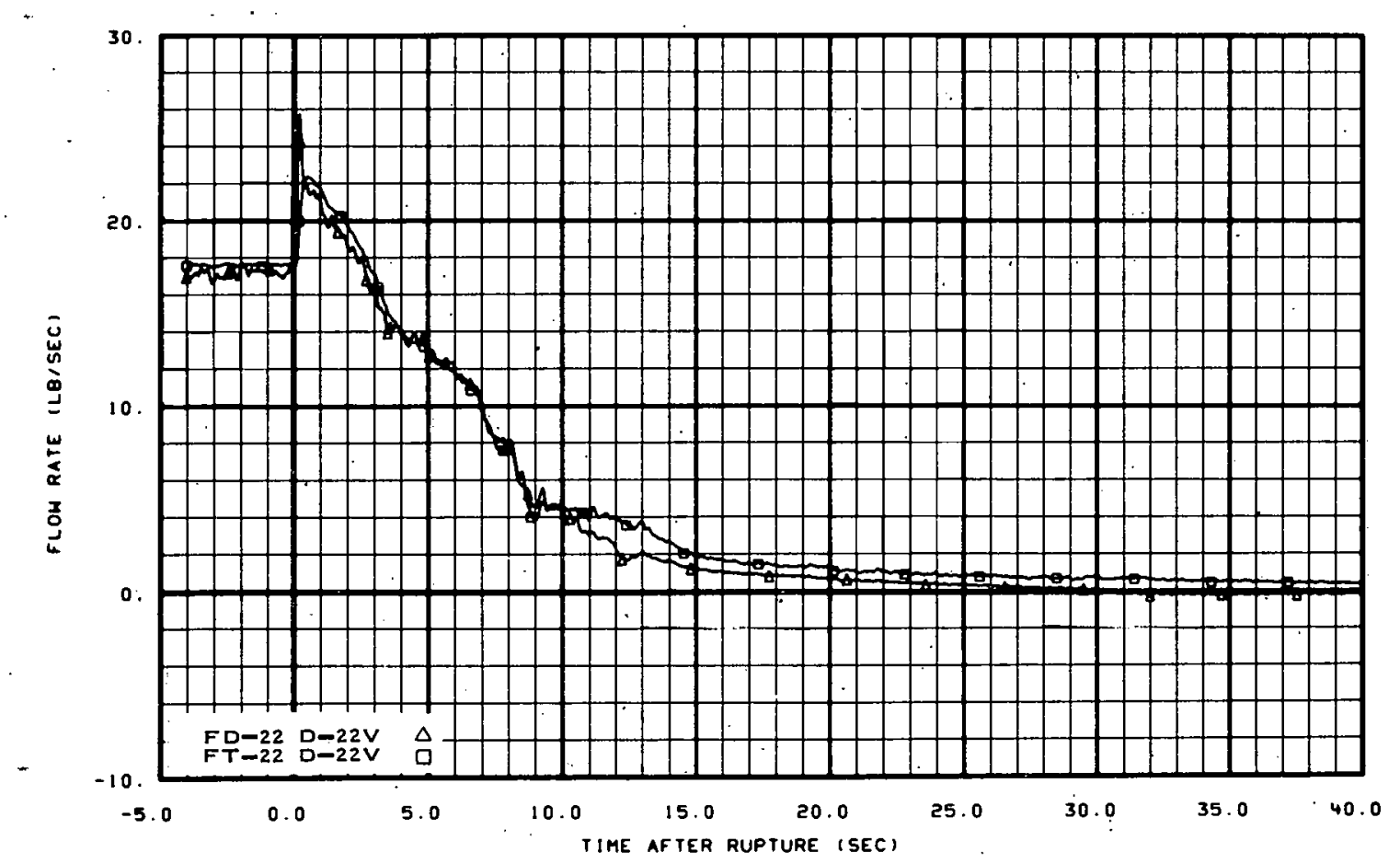

Fig. 76 Mass flow rate in operating loop cold leg Spool 22 -- Test 1002: 


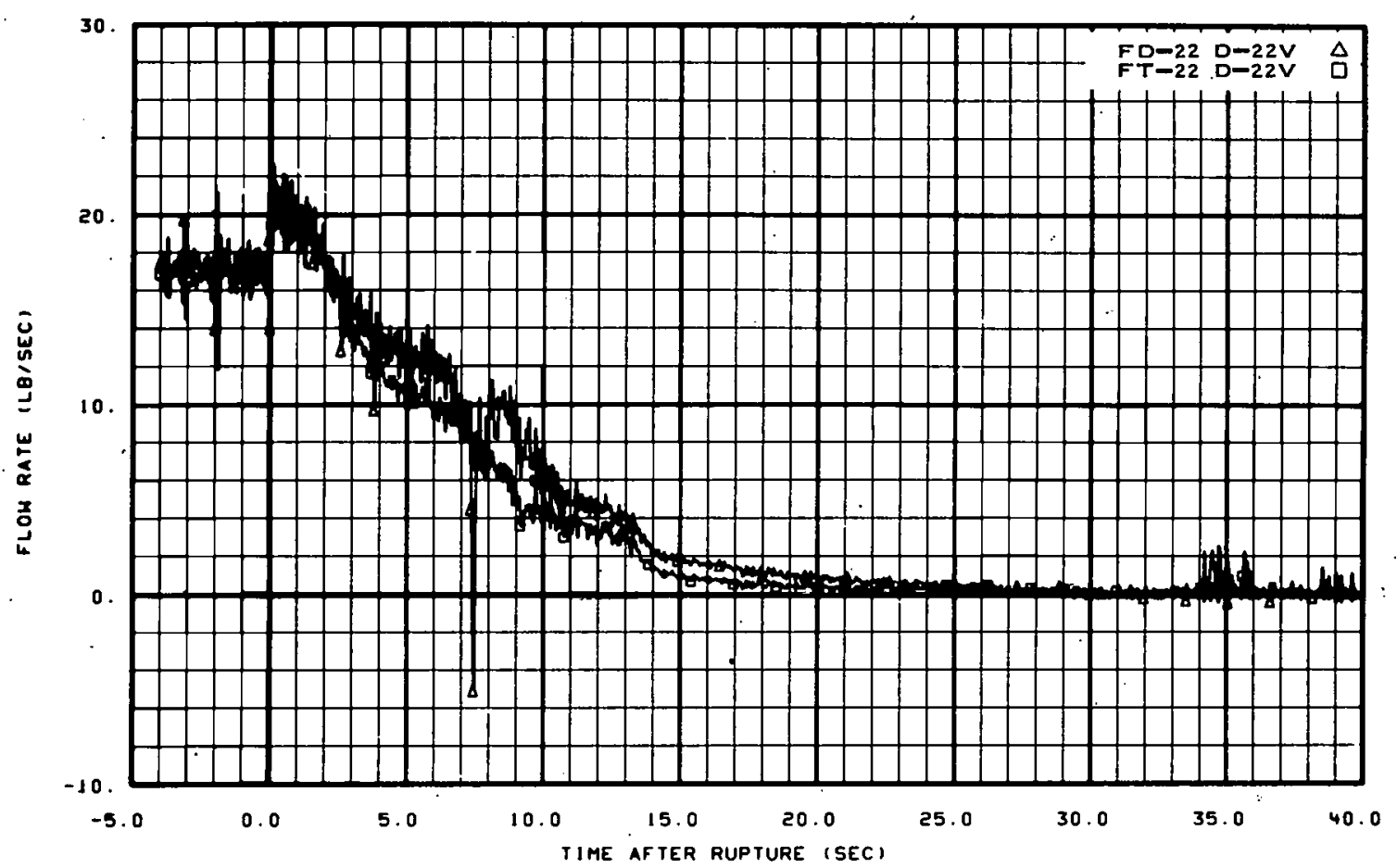

Fig. 77 Mass flow rate in operating loop cold leg Spool 22 -- Test 1003.

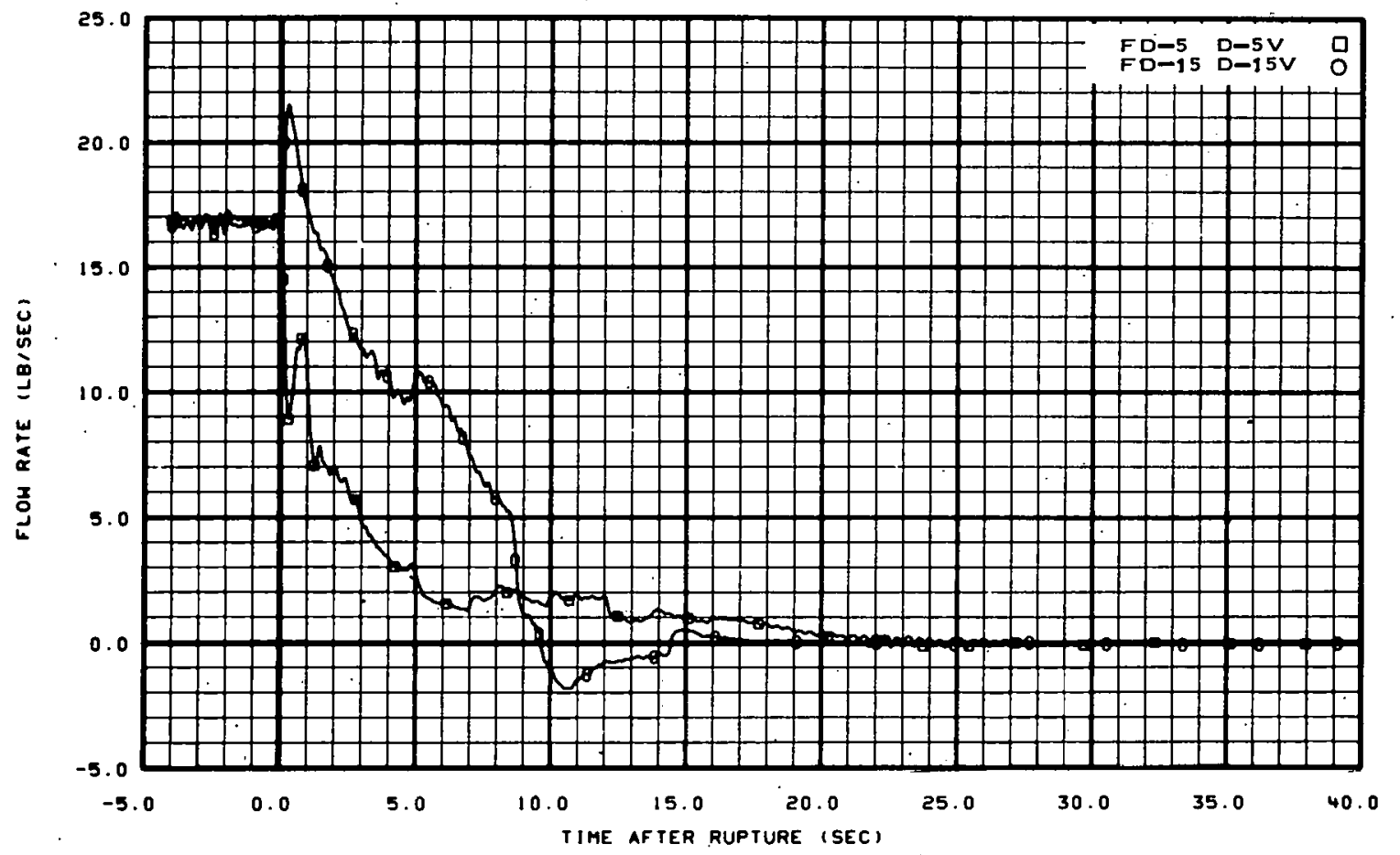

Fig. 78 Mass flow rate in operating loop Spools 5 and 15 - Test 1001. 


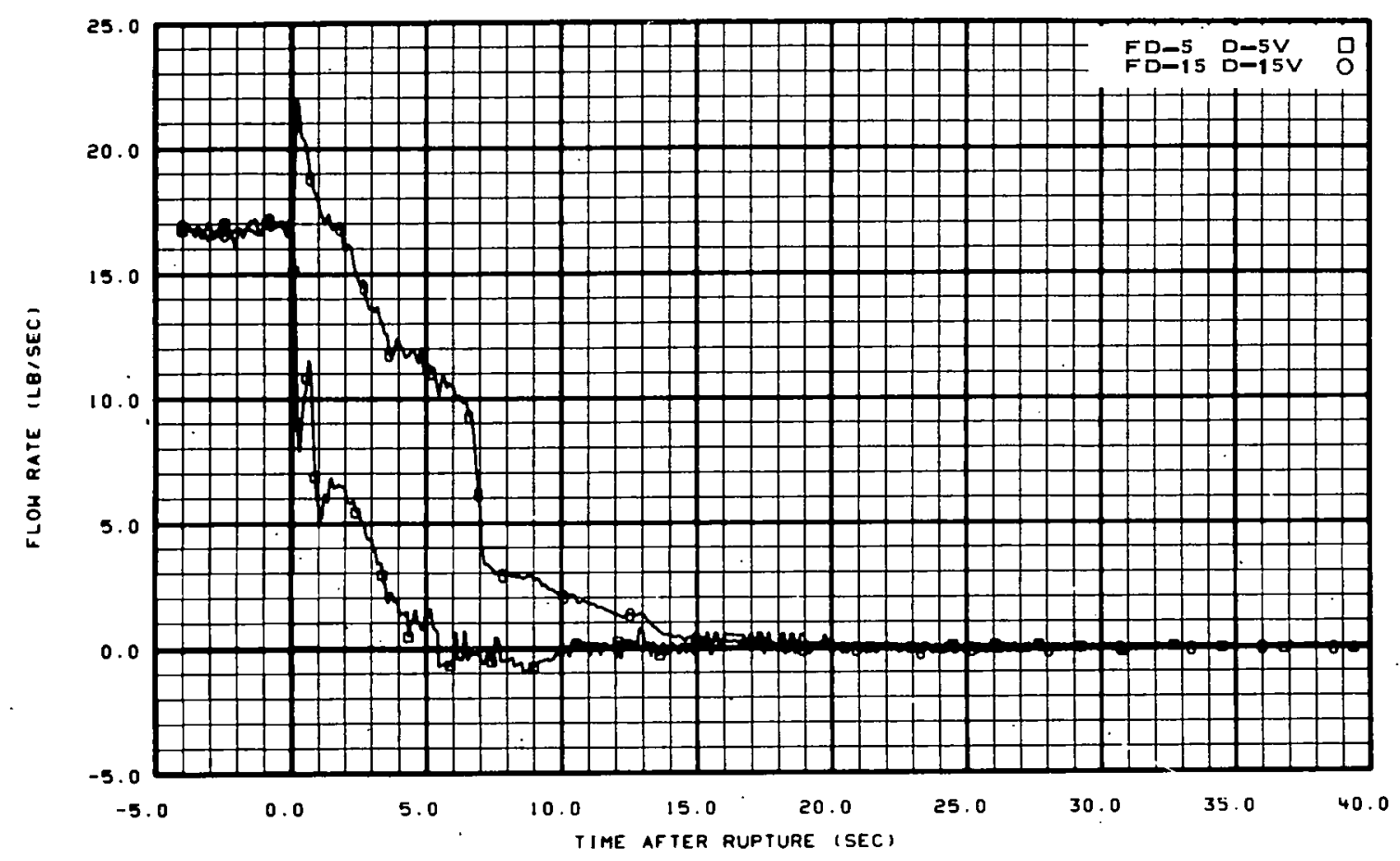

Fig. 79 Mass flow rate in operating loop Spools 5 and 15 -- Test 1002.

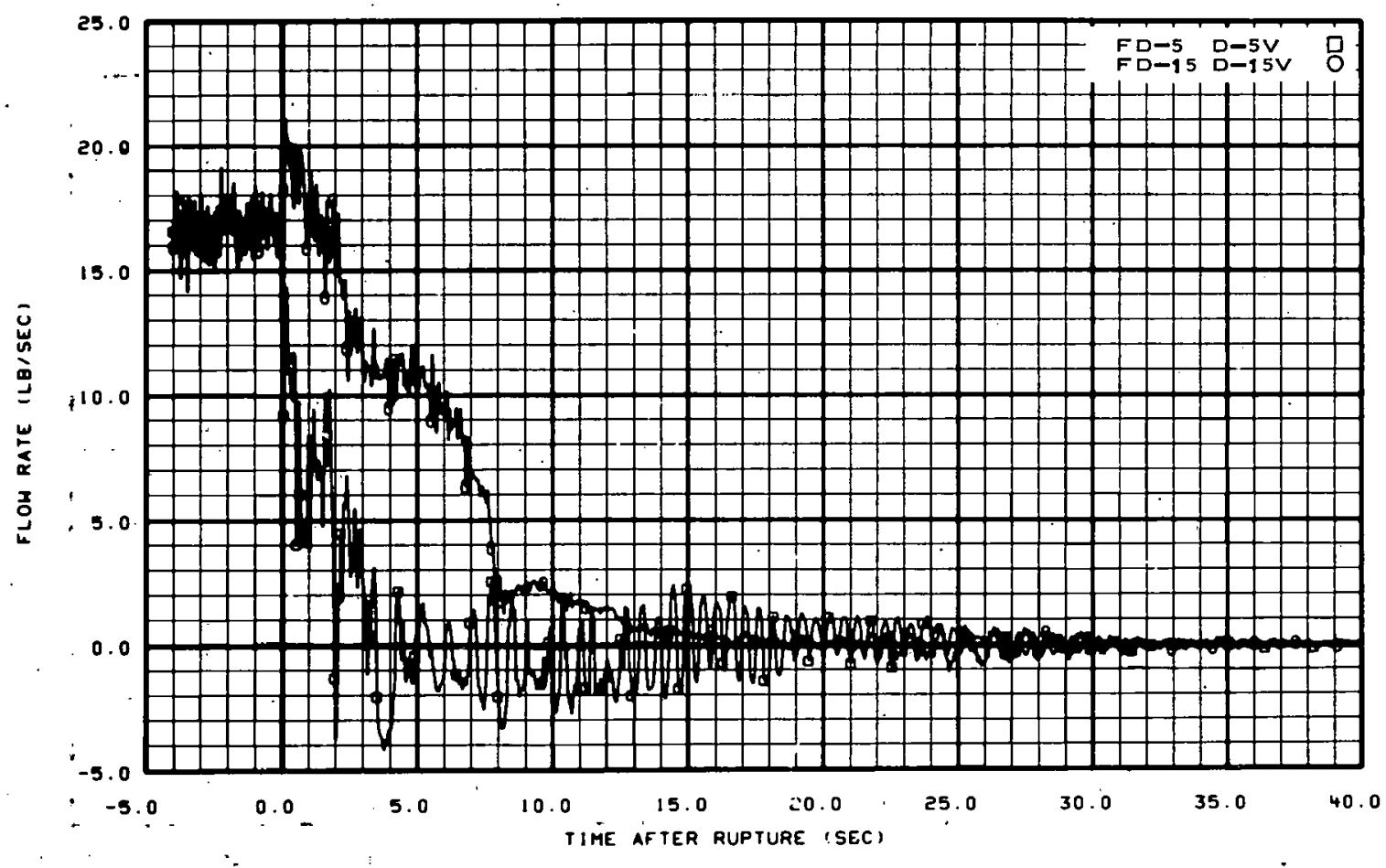

Fig. 80 Mass flow rate in operating loop spools 5 and 15 -- Test 1003. 


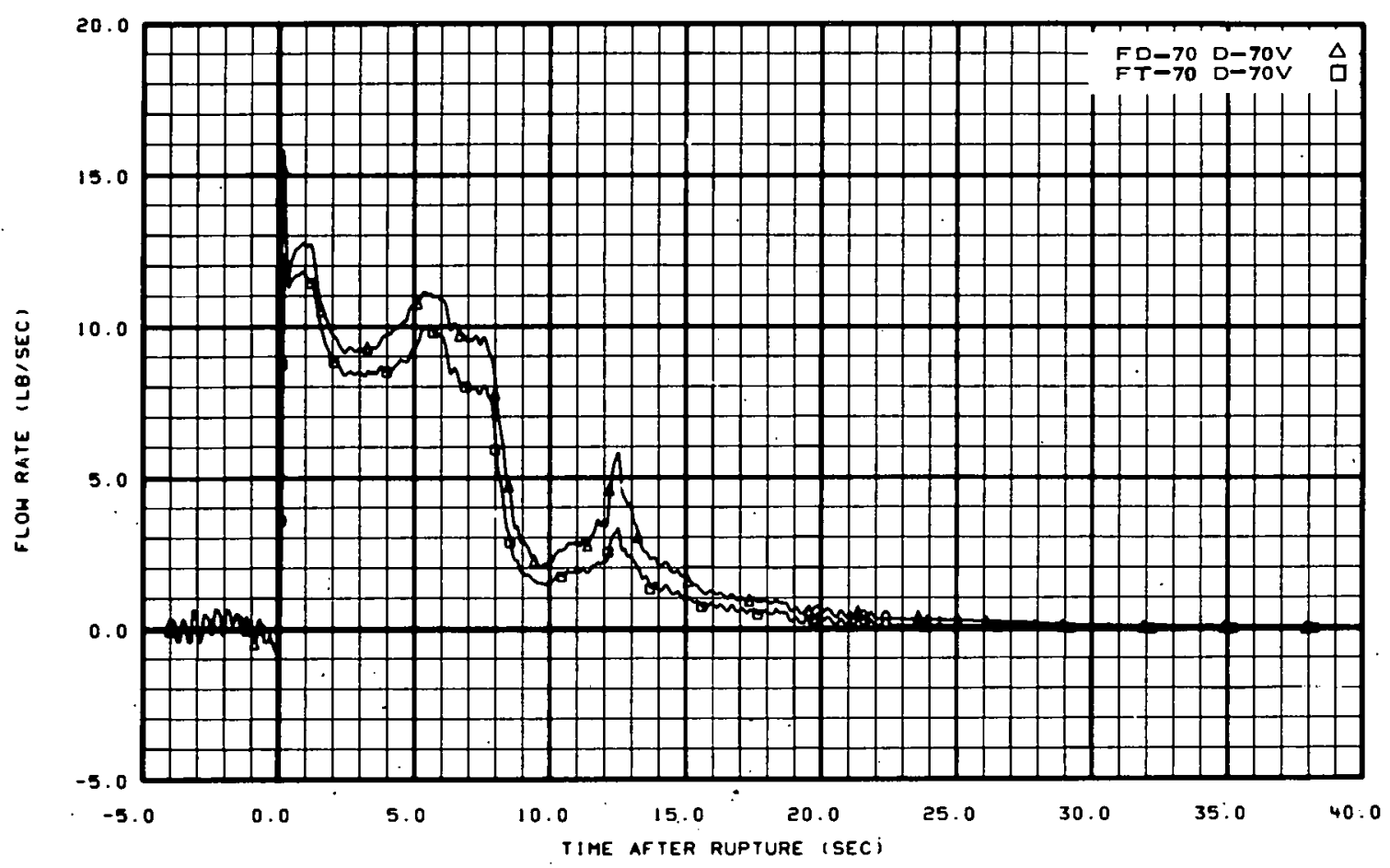

Fig. 81 Mass flow rate in blowdown loop Spool 70 -- Test 1001.

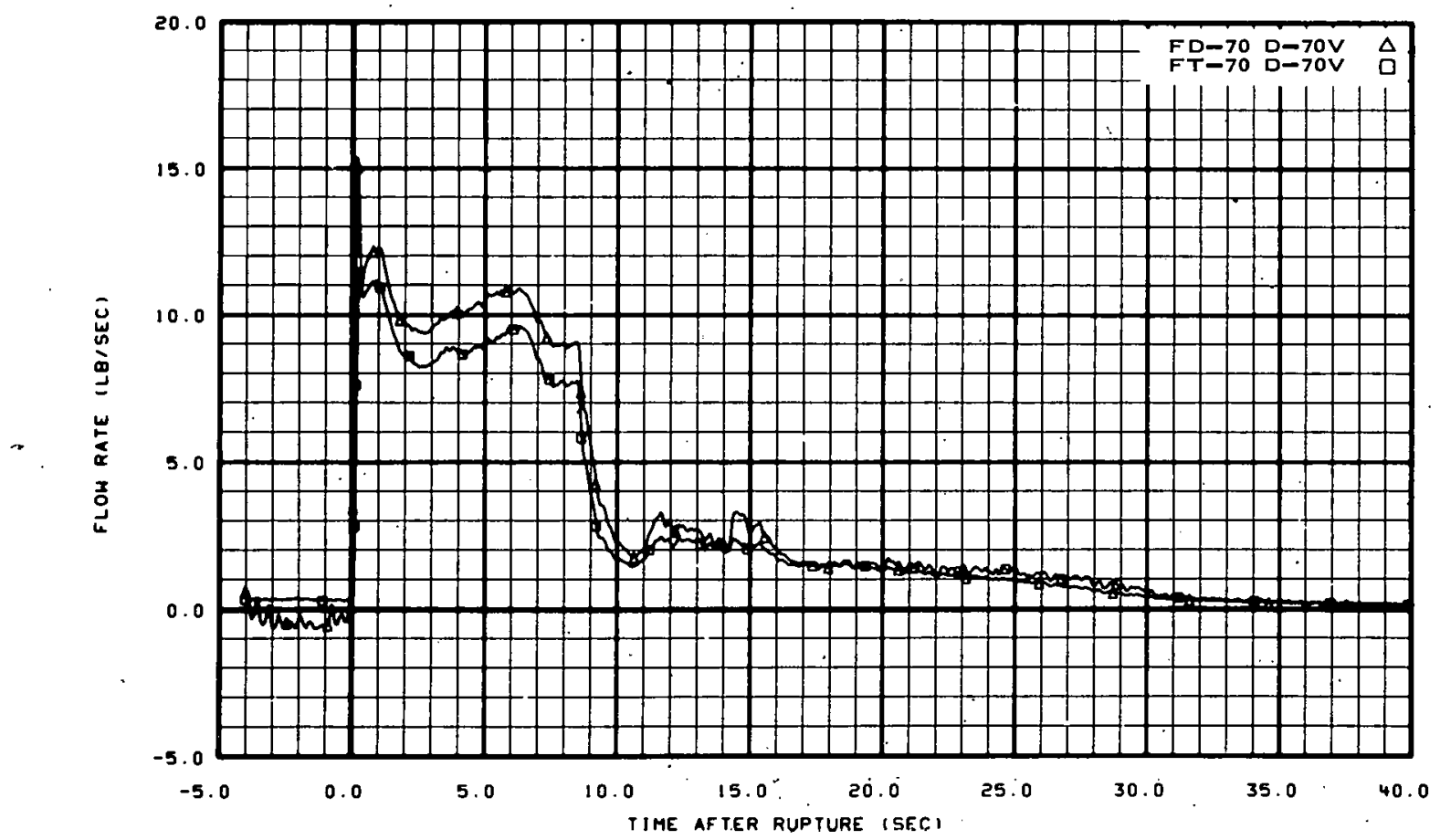

Fig. 82 Mass flow rate in blowdown loop spool 70 -- Test 1002. 


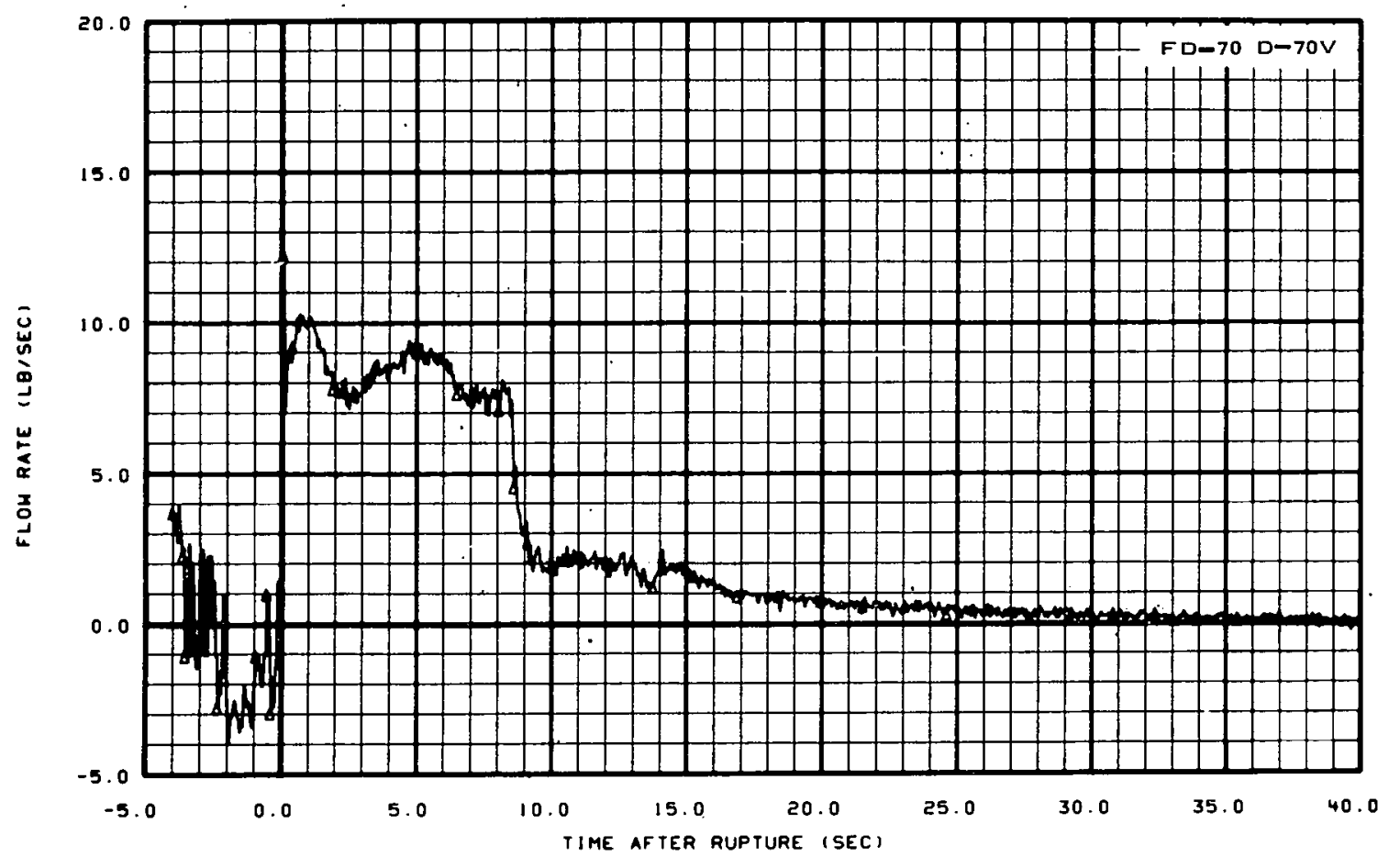

Fig. 83 Mass flow rate in blowdown loop spool 70 -- Test 1003.

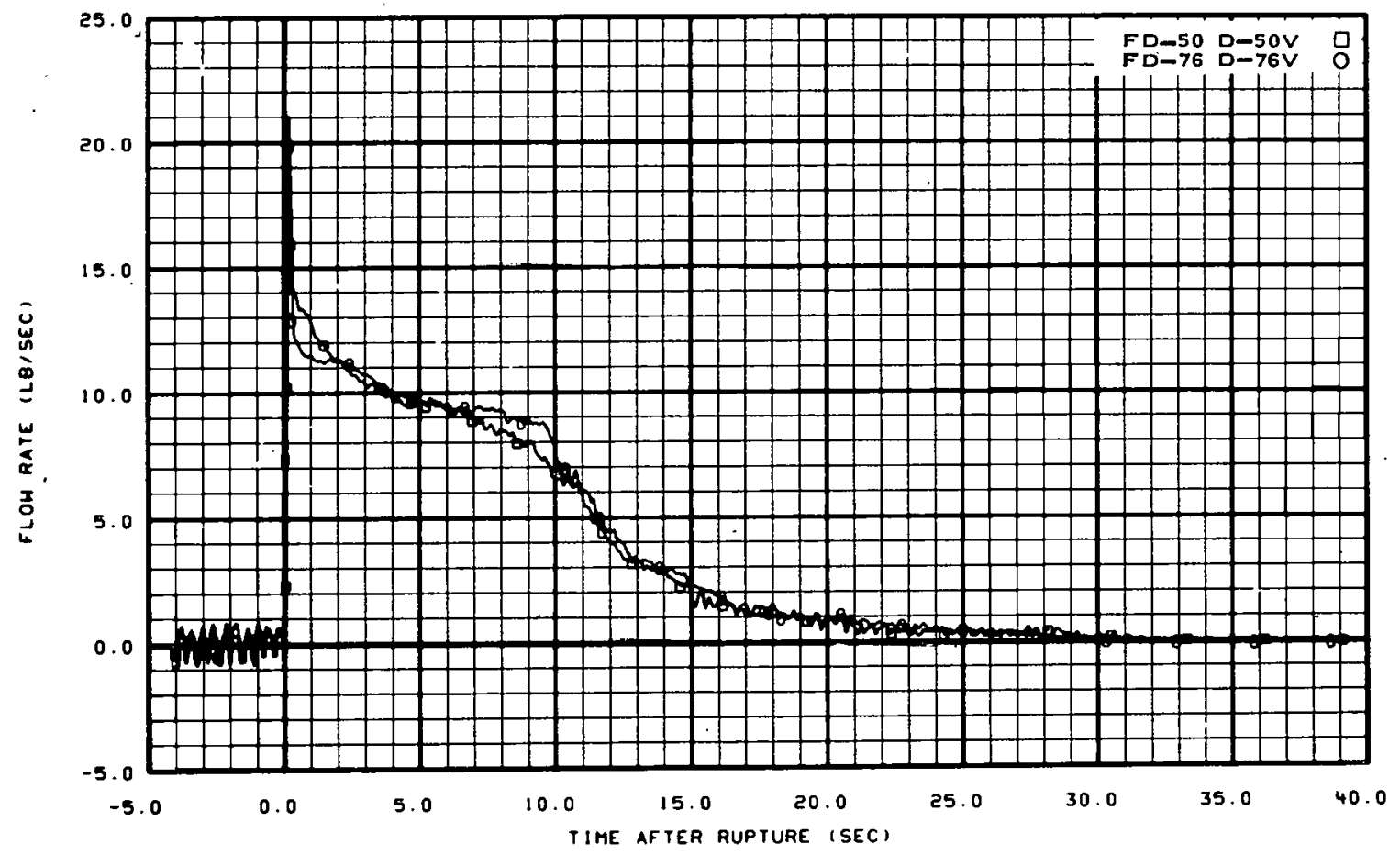

Fig. 84 Mass flow rate in blowdown loop "Spools 50 and 76 -- Test 1001. 


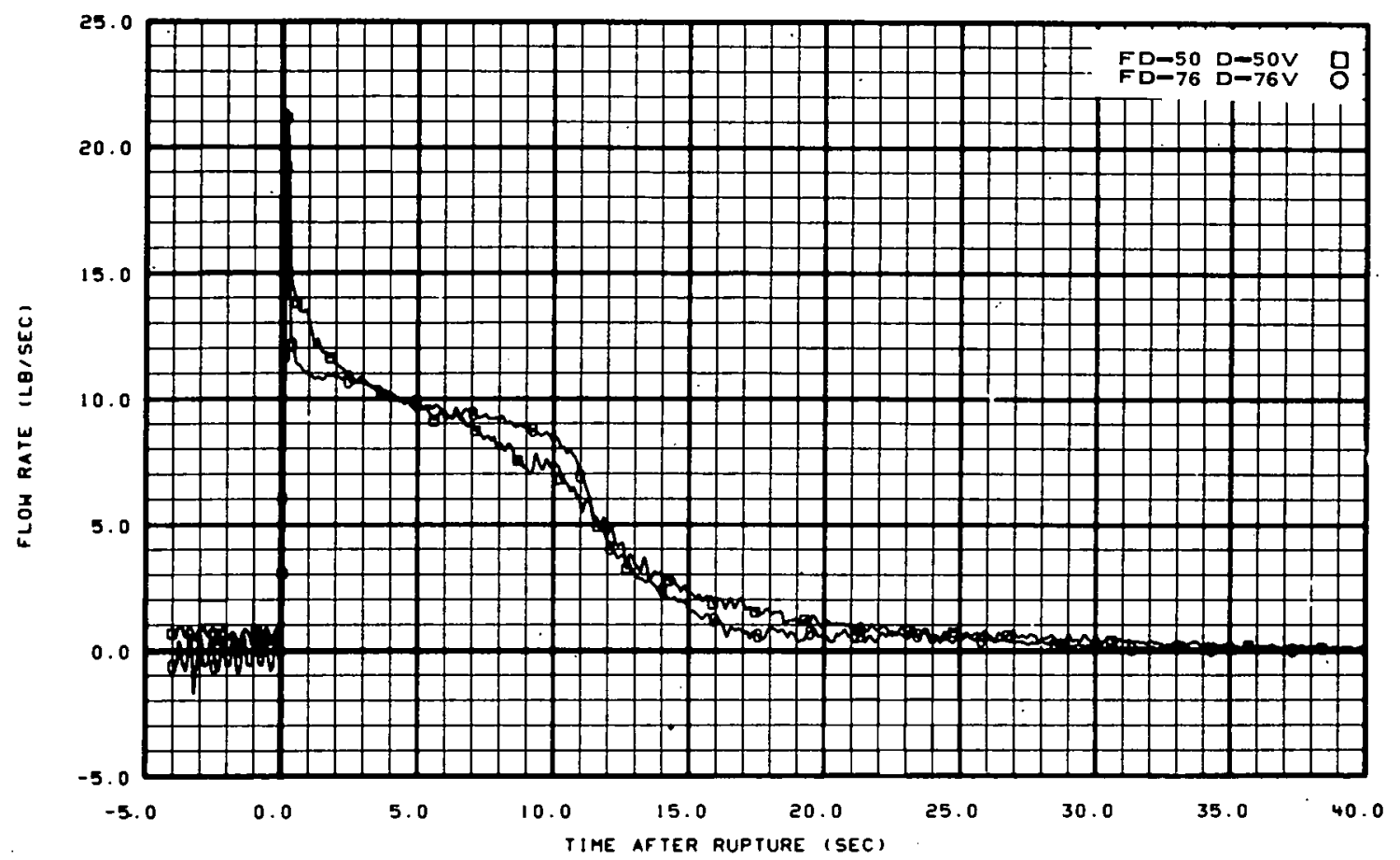

Fig. 85 Mass flow rate in blowdown loop Spools 50 and 76 -- Test 1002 .

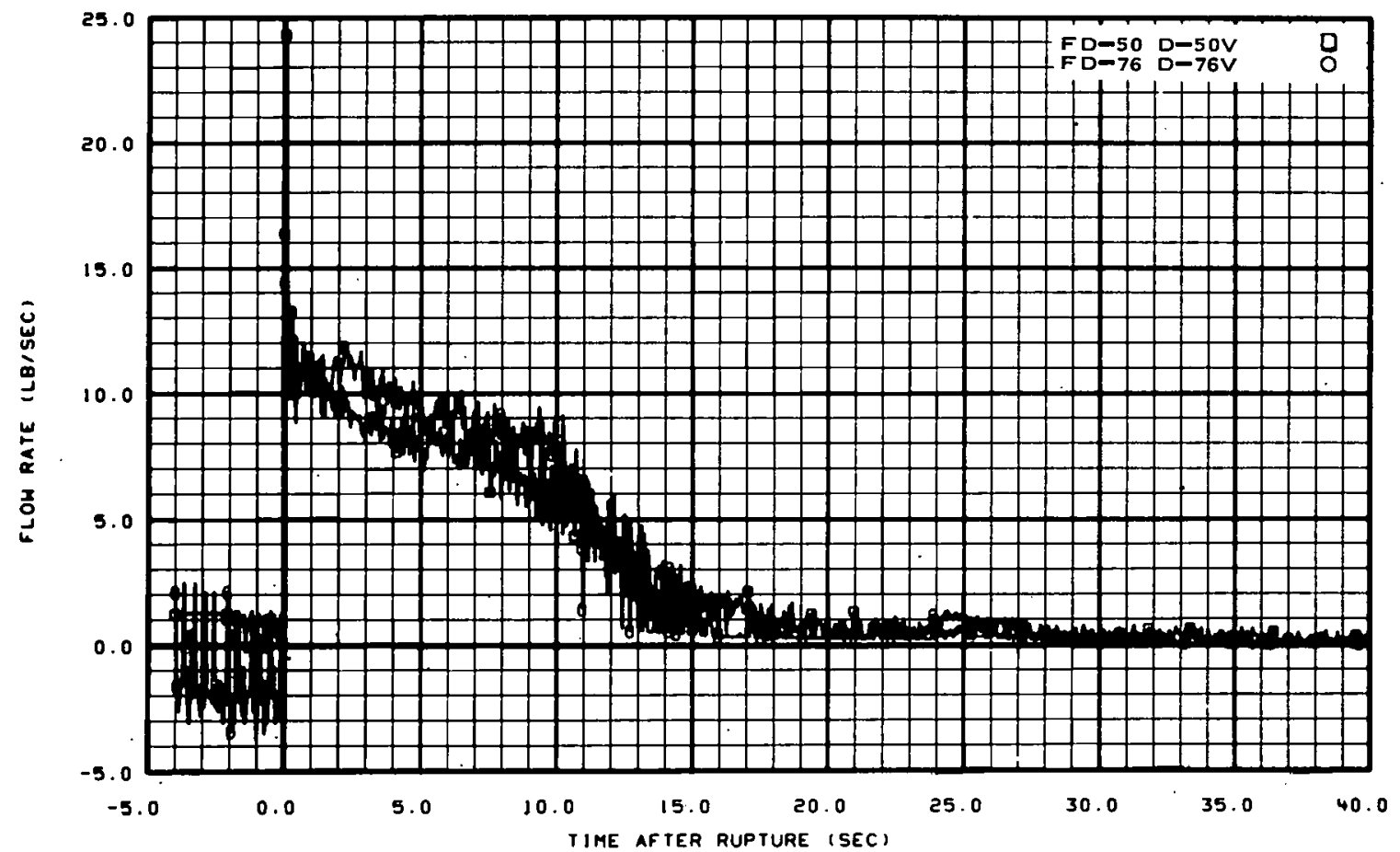

Fig. 86 Mass flow rate in blowdown loop Spools 50 and 76 -- Test 1003. 


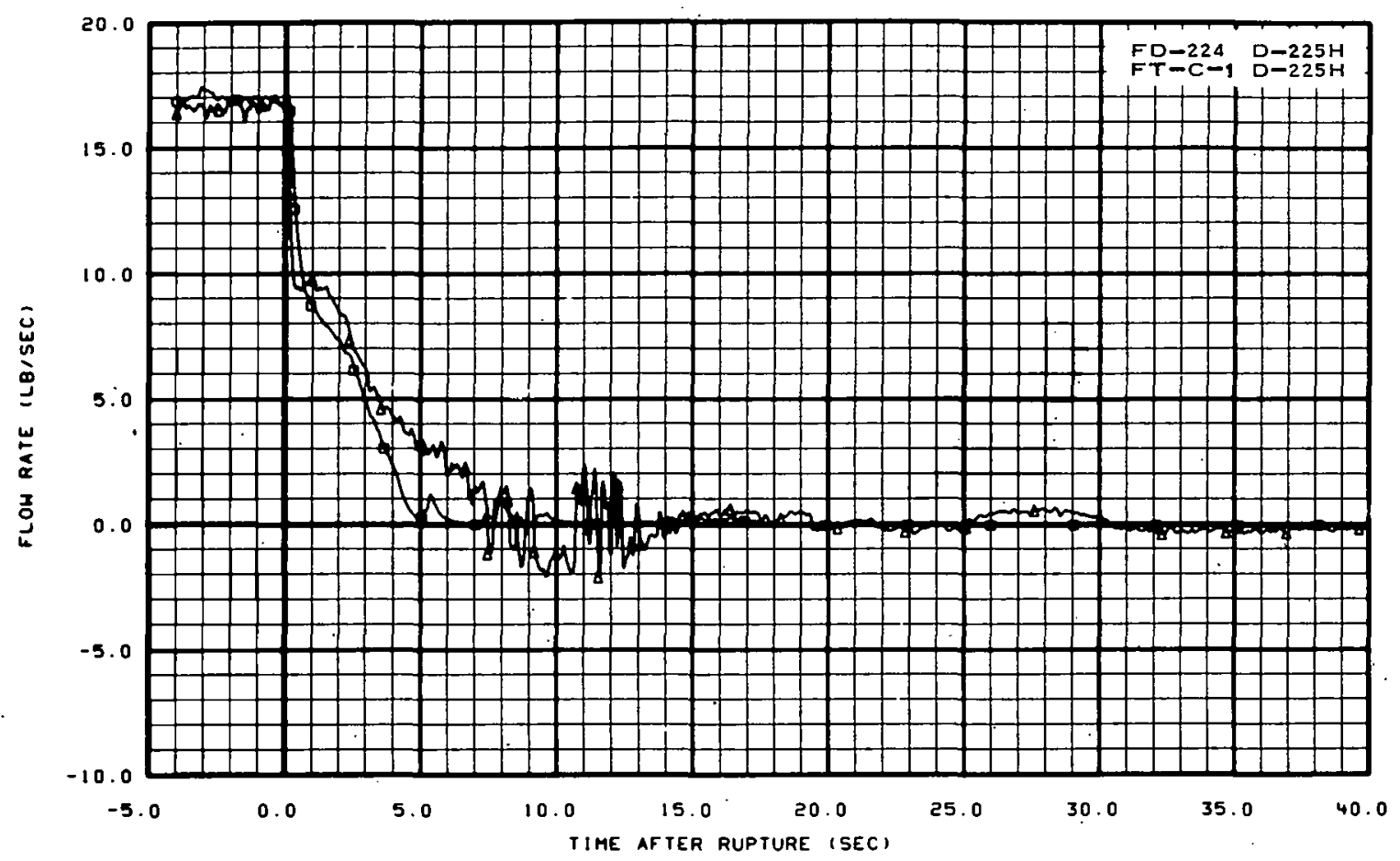

Fig. 87 Mass flow rate at core barrel inlet -- Test 1001.

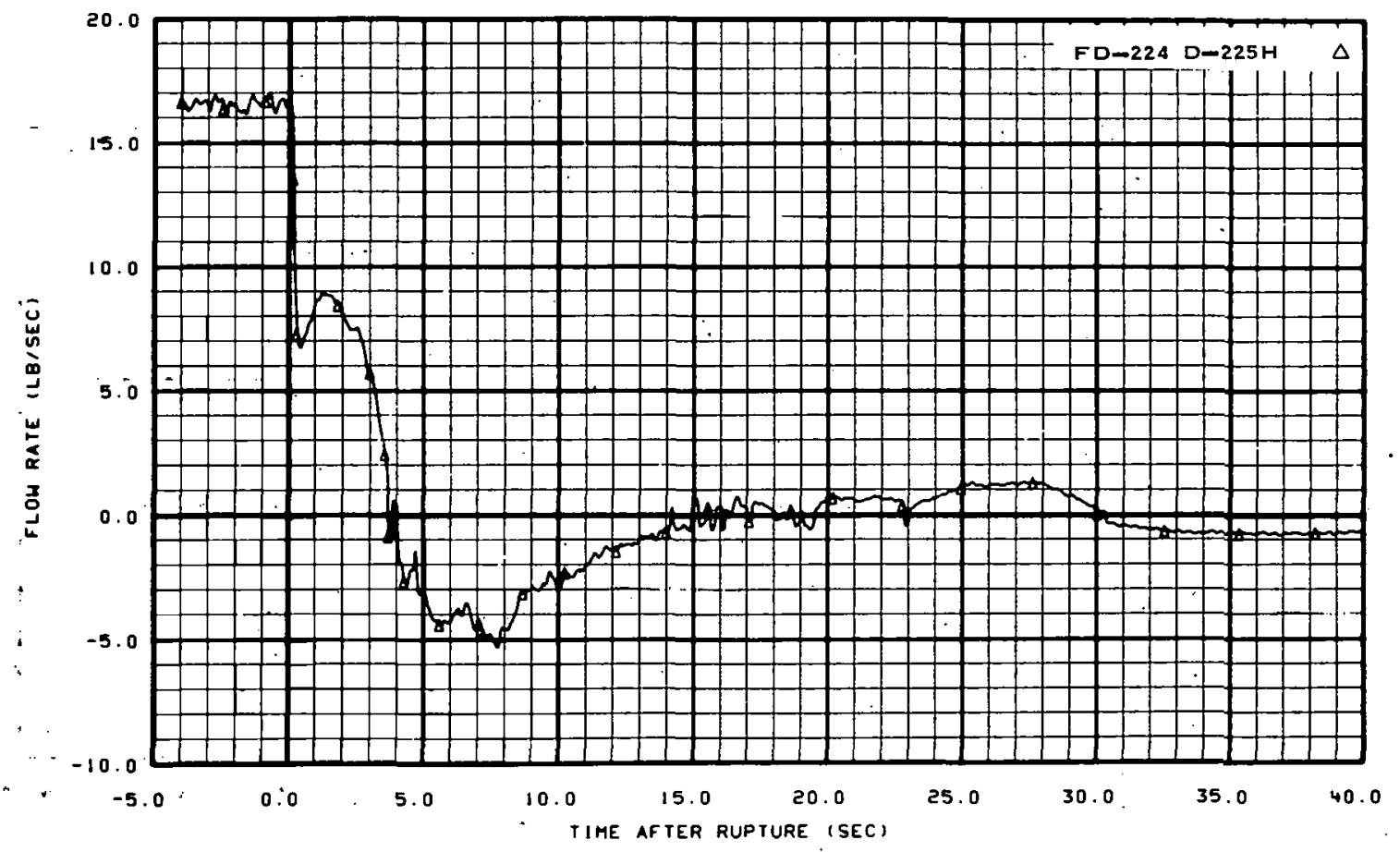

․ Fig. 88 Mass flọ rate at core barrel 'inlet -- Test 1002. 


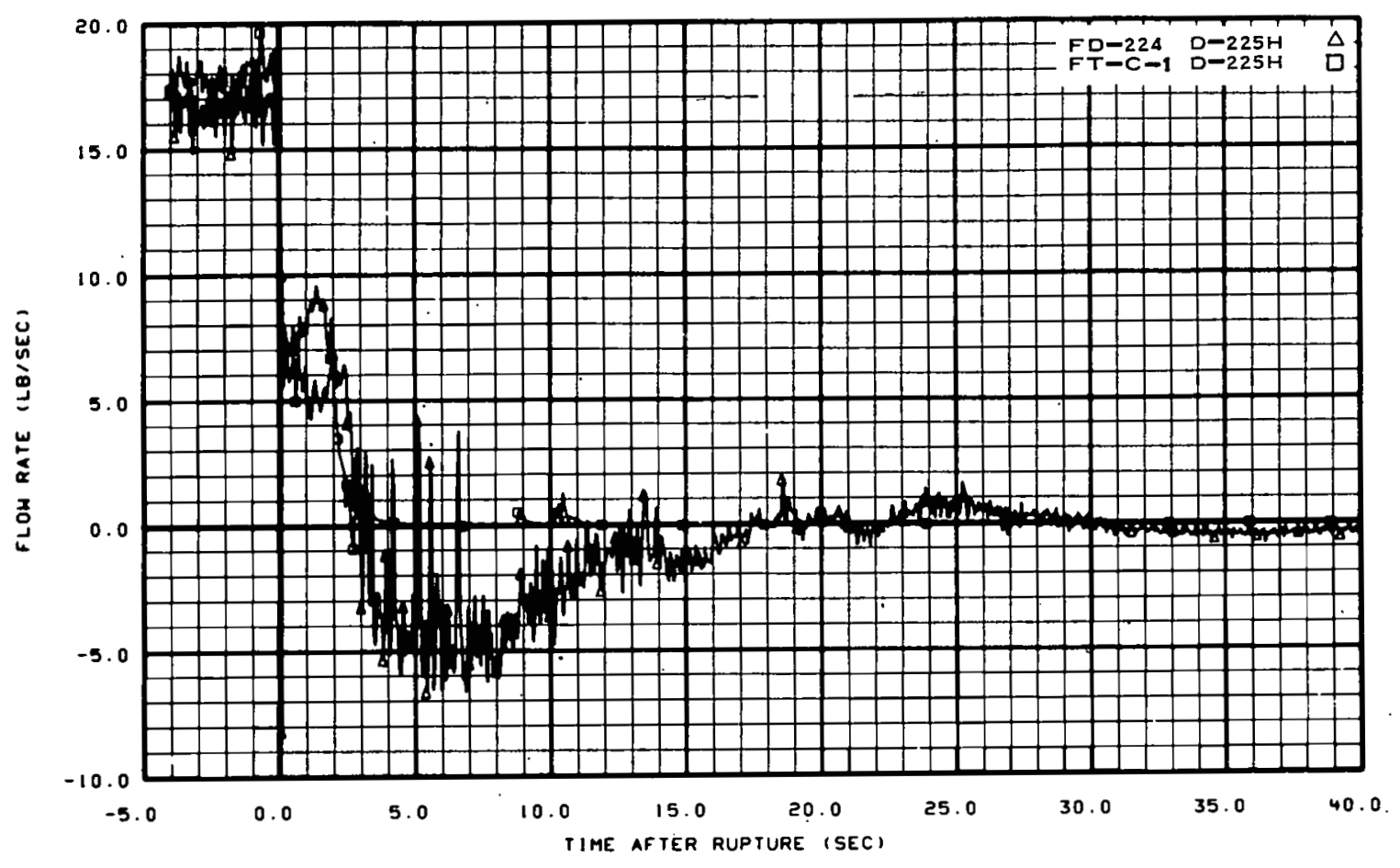

Fig. 89 Mass flow rate at core barrel inlet -- Test 1003.

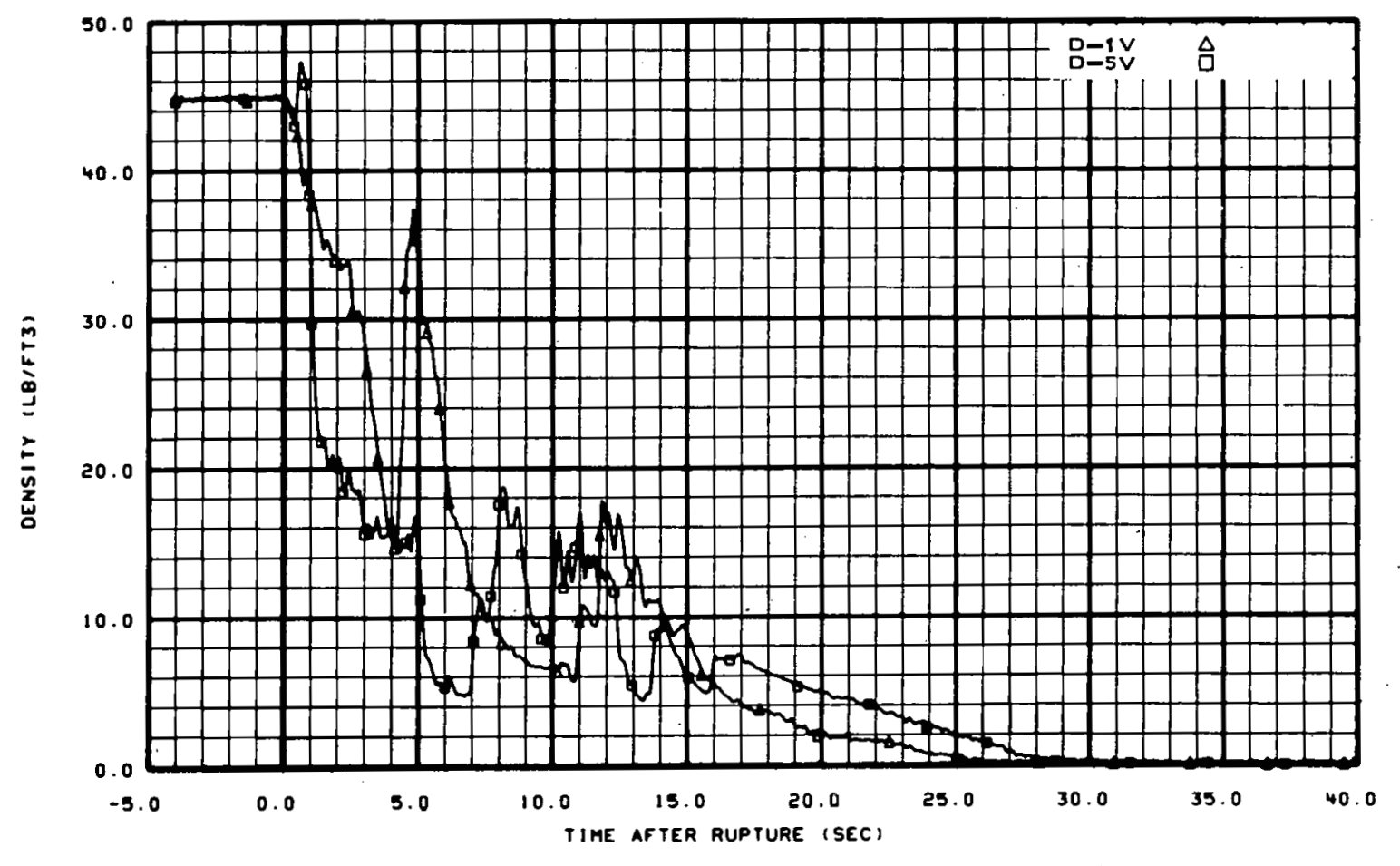

Fig. 90 Fluid density in operating loop hot leg -- Test 1001. 


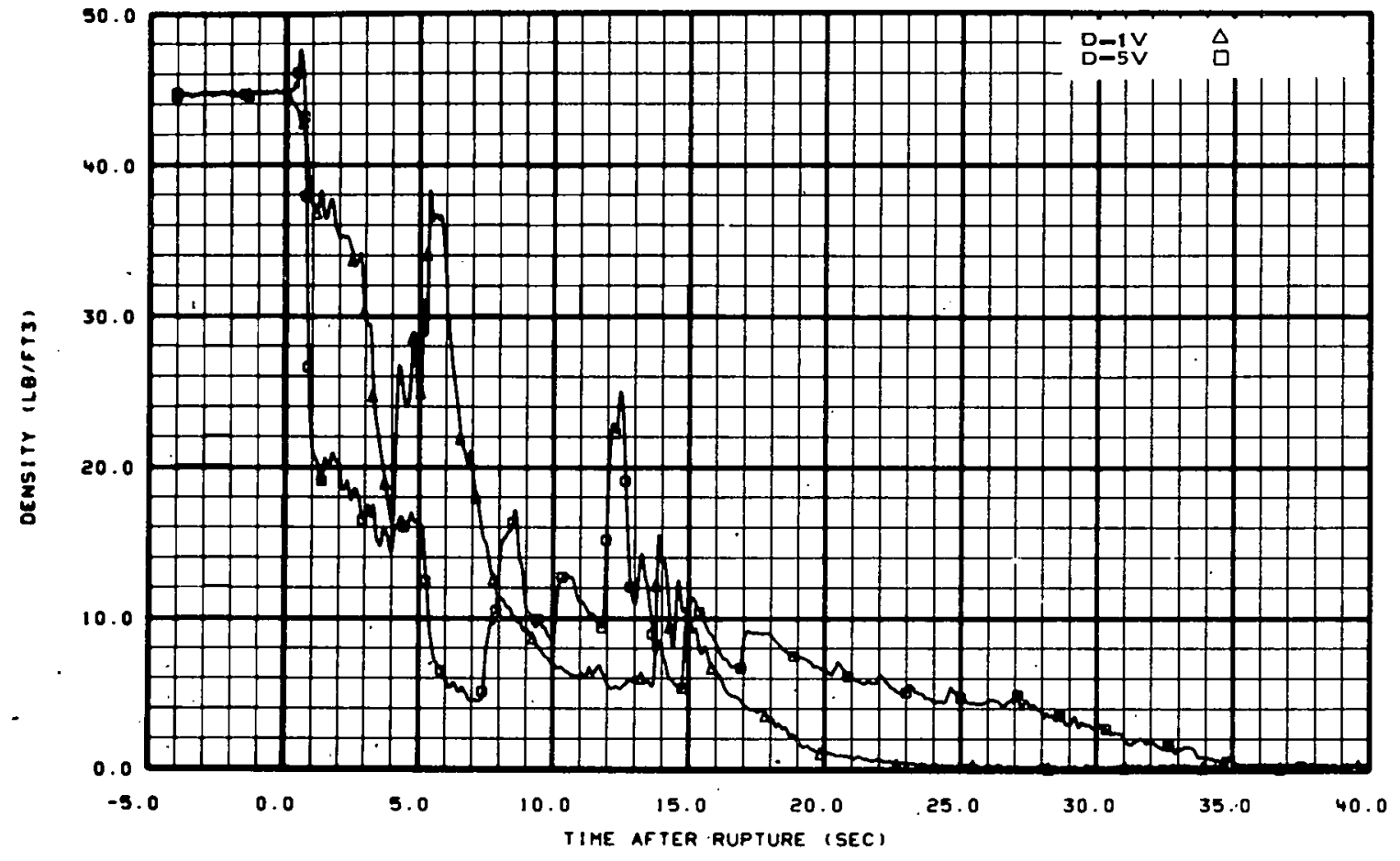

Fig. 91 Fluid density in operating loop hot leg -- Test 1002.

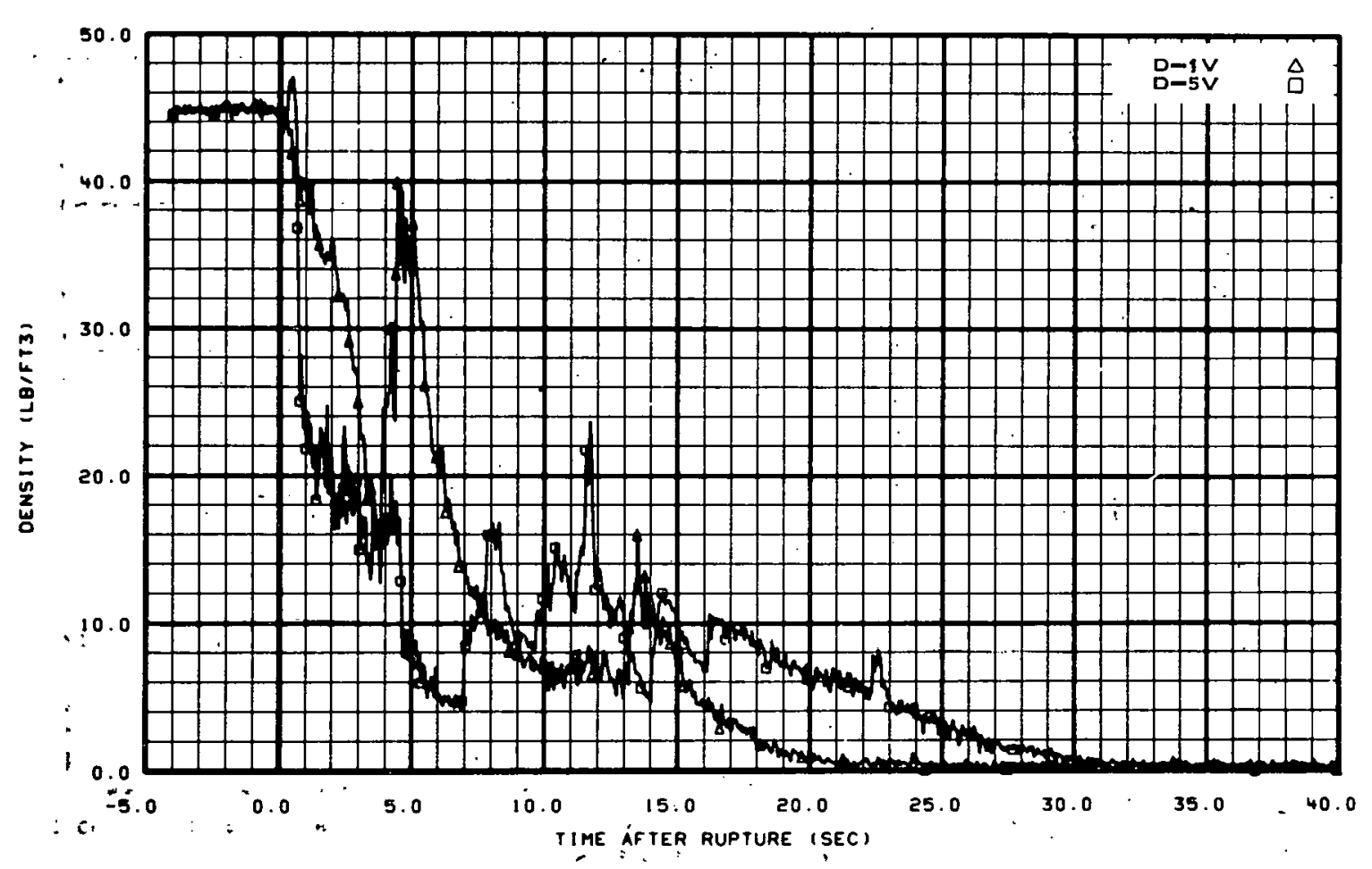

Fig. 92 Fluid density in operating loop hot leg - Test 1003: 


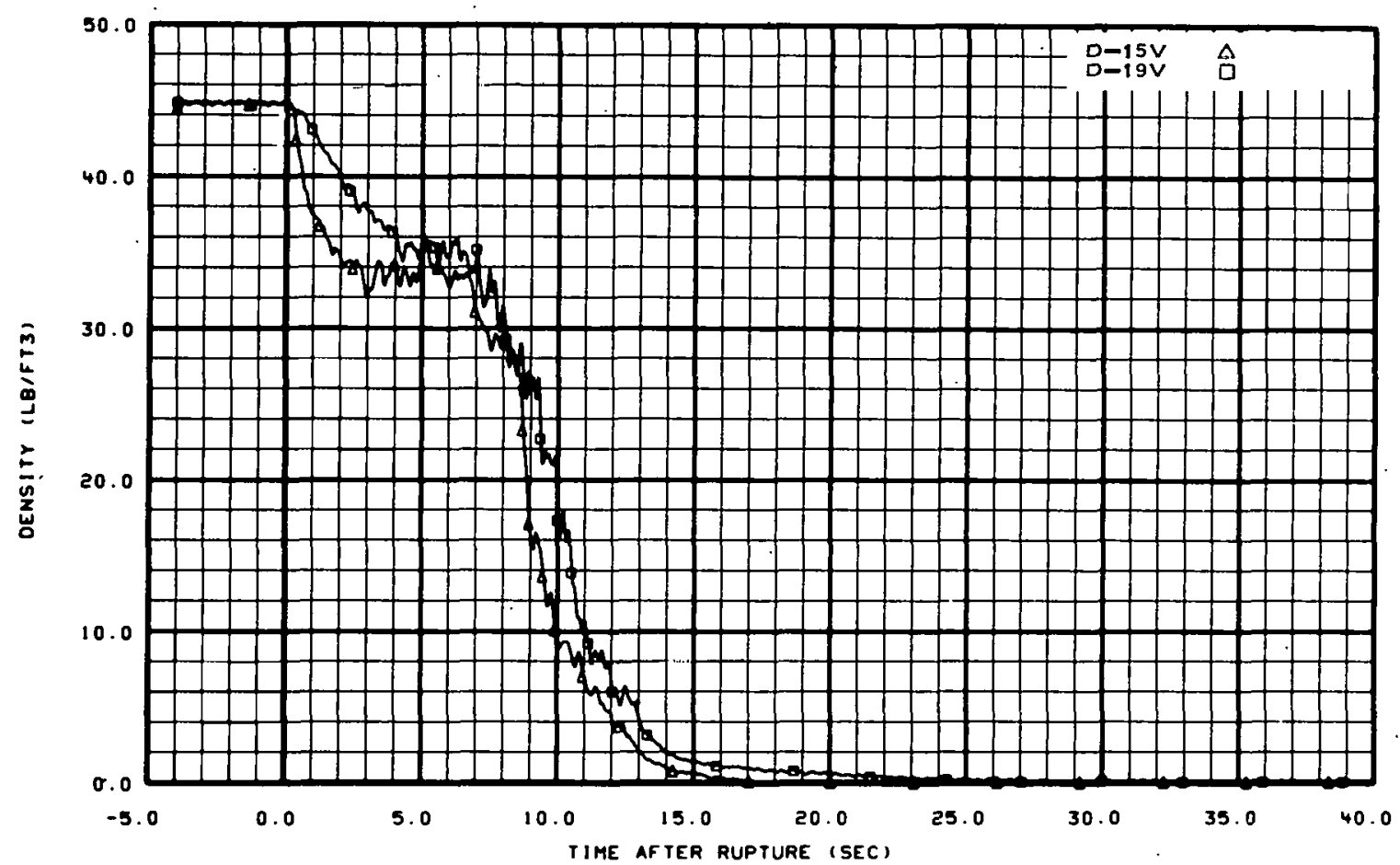

Fig. 93 Fluid density at operating loop pump inlet and outlet -- Test 1001.

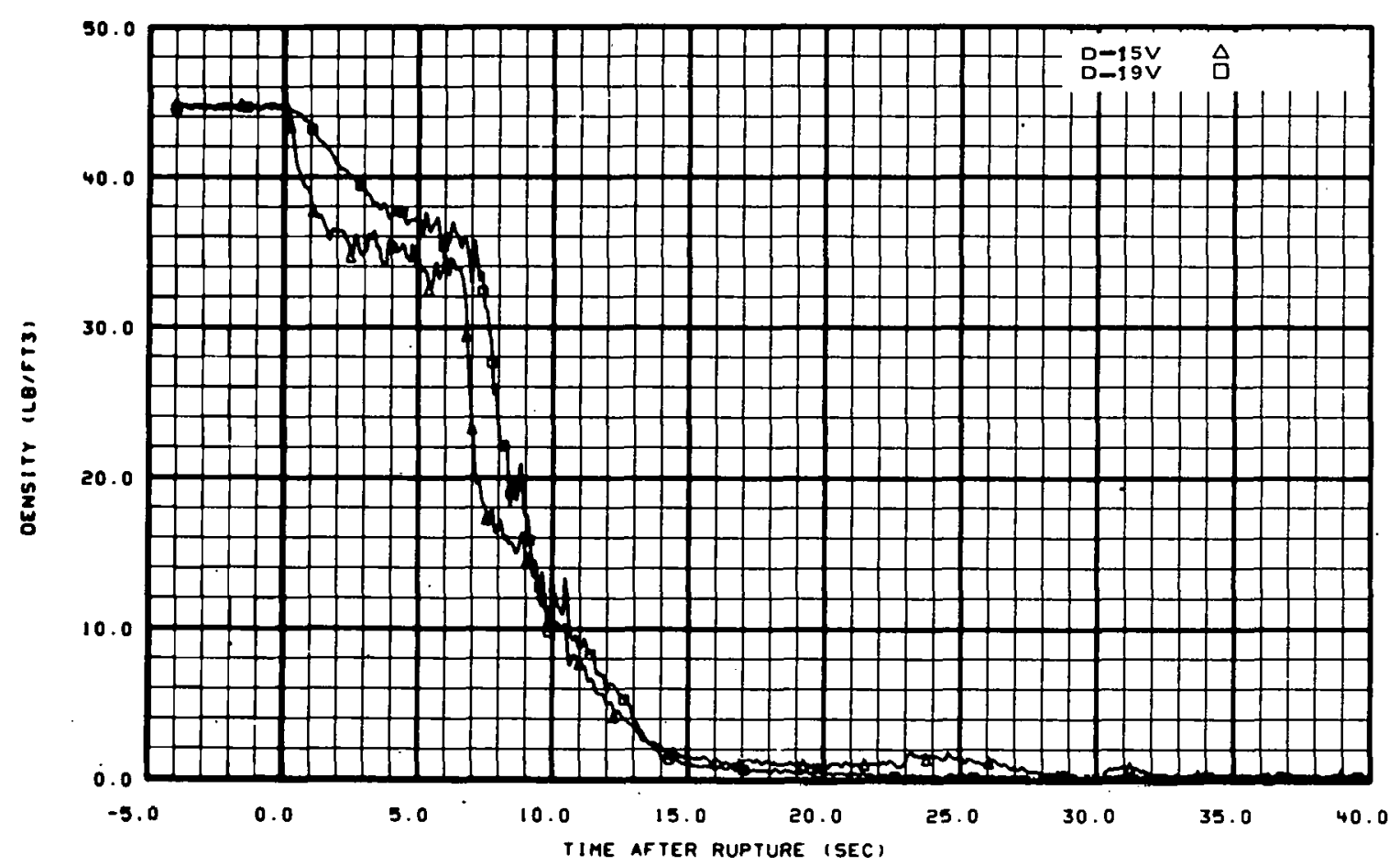

Fig. 94 Fluid density at operating loop pump inlet and outlet -- Teet 1002. 


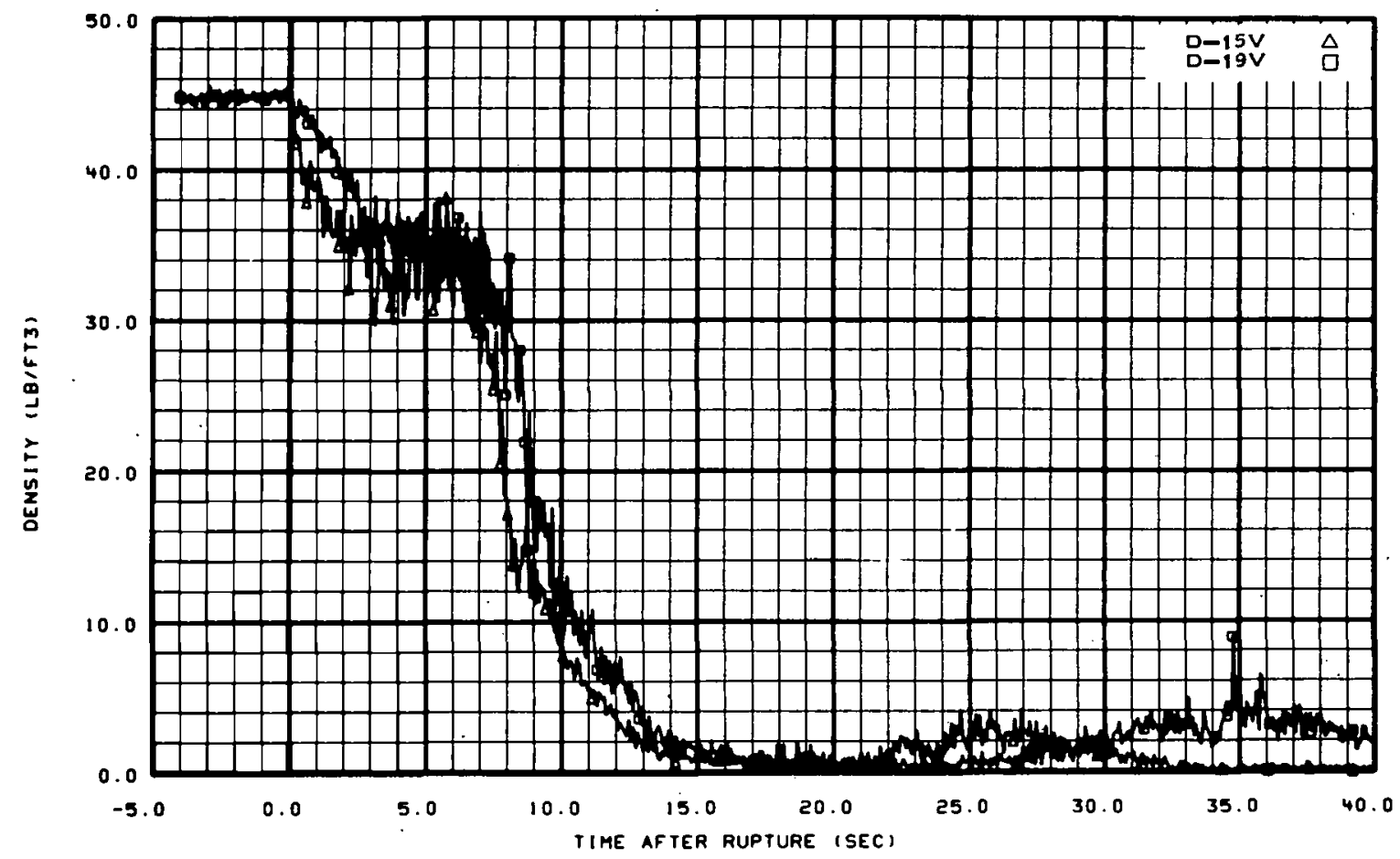

Fig. 95 Fluid density at operating loop pump inlet and ouṭlet -- Test 1003.

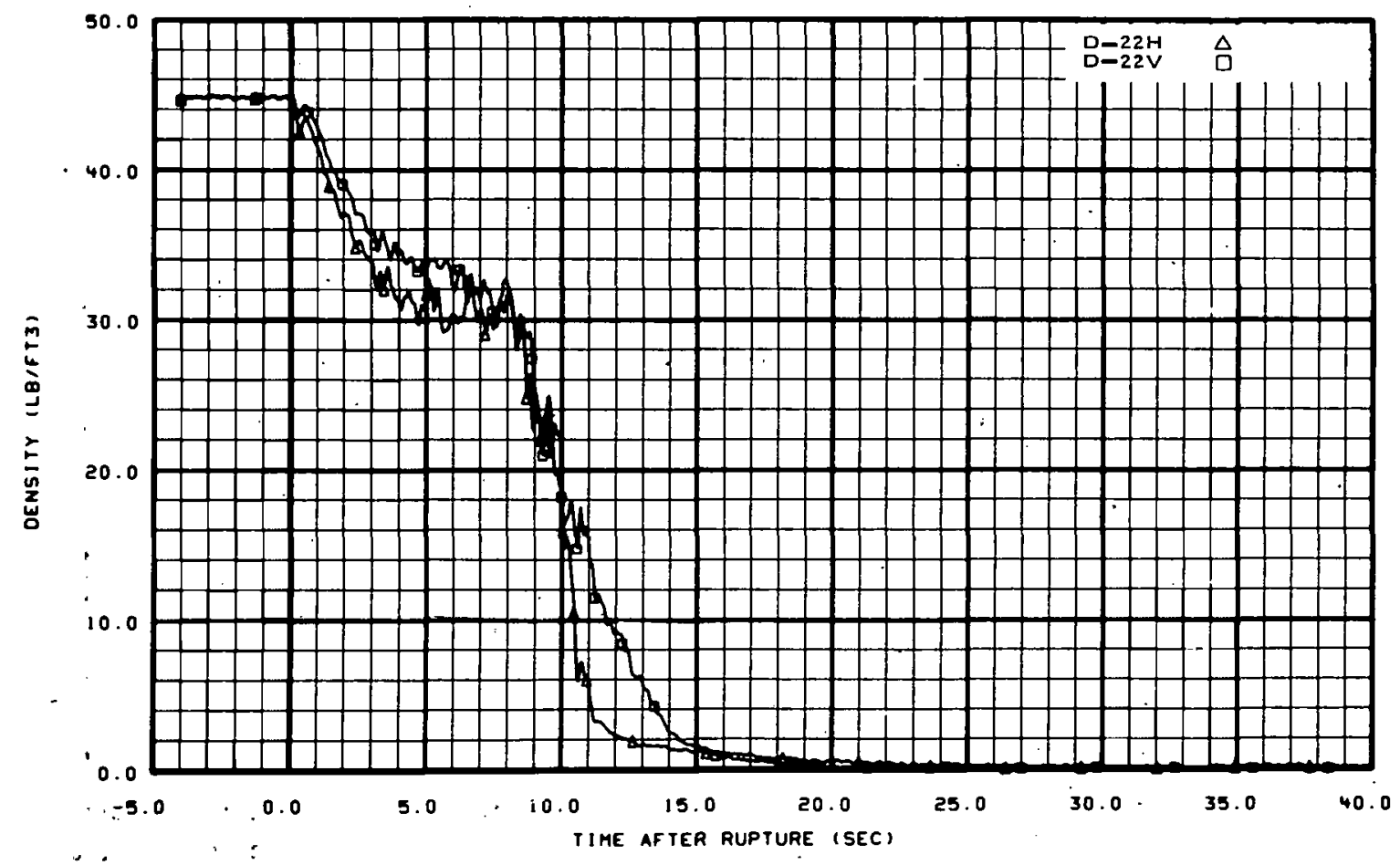

Fig. 96 Fluid density in operating loop cold leg -- Test 1001. 


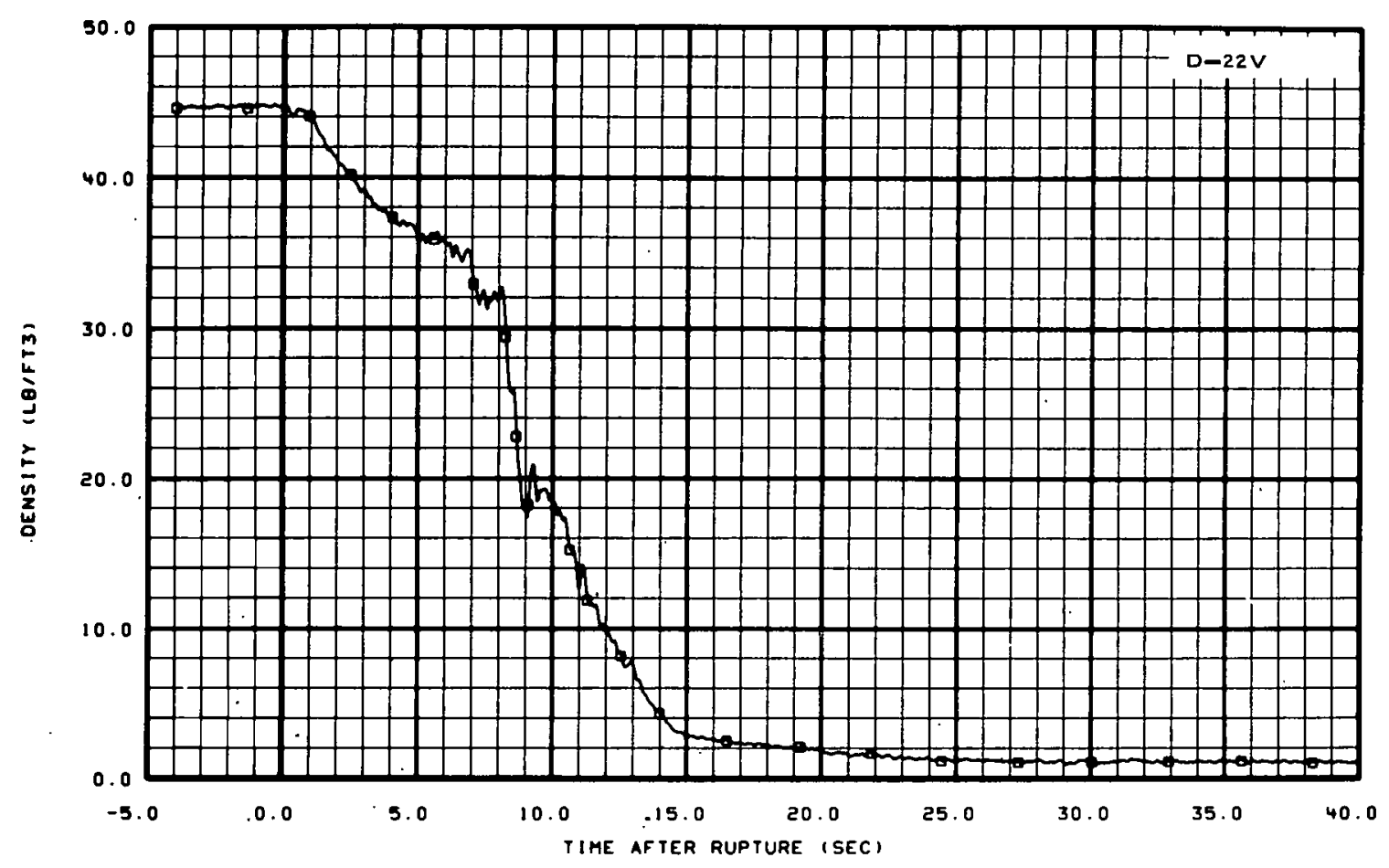

Fig. 97 Fluid density in operating loop cold leg -- Test 1002.

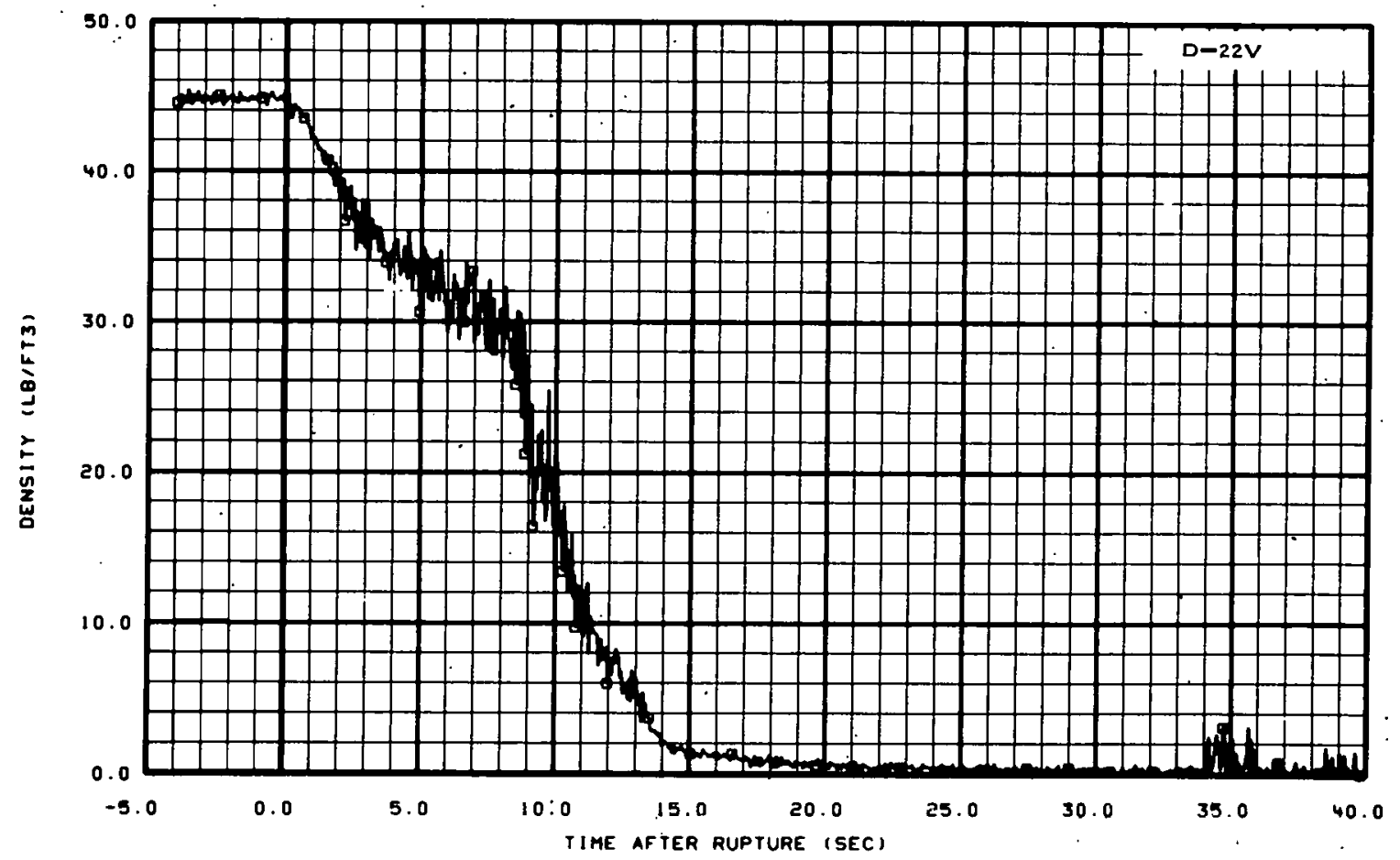

Fig. 98 Fluid density in operating loop cold leg -- Test 1.003. 


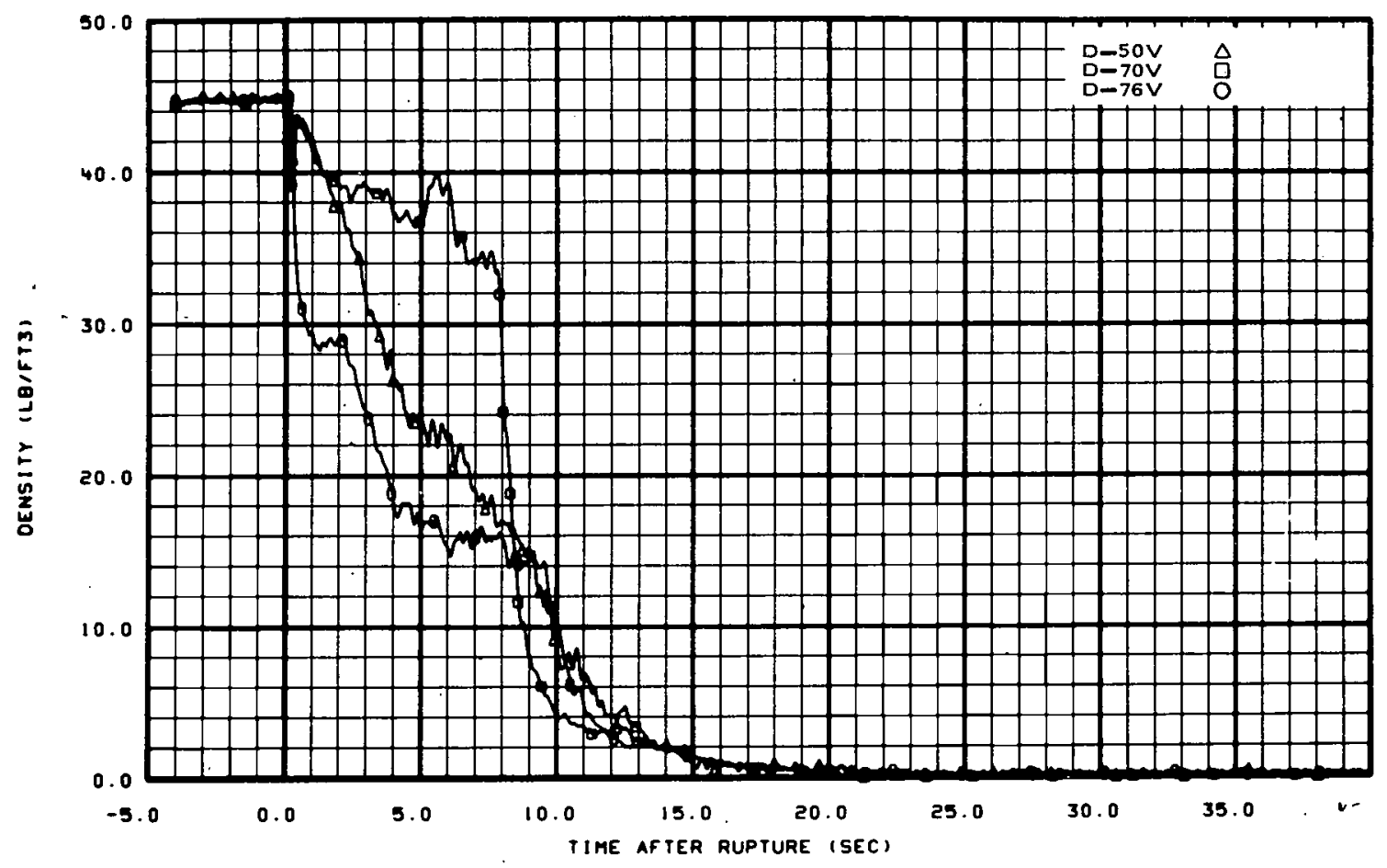

Fig. 99 Fluid density in blowdown loop -- Test 1001.

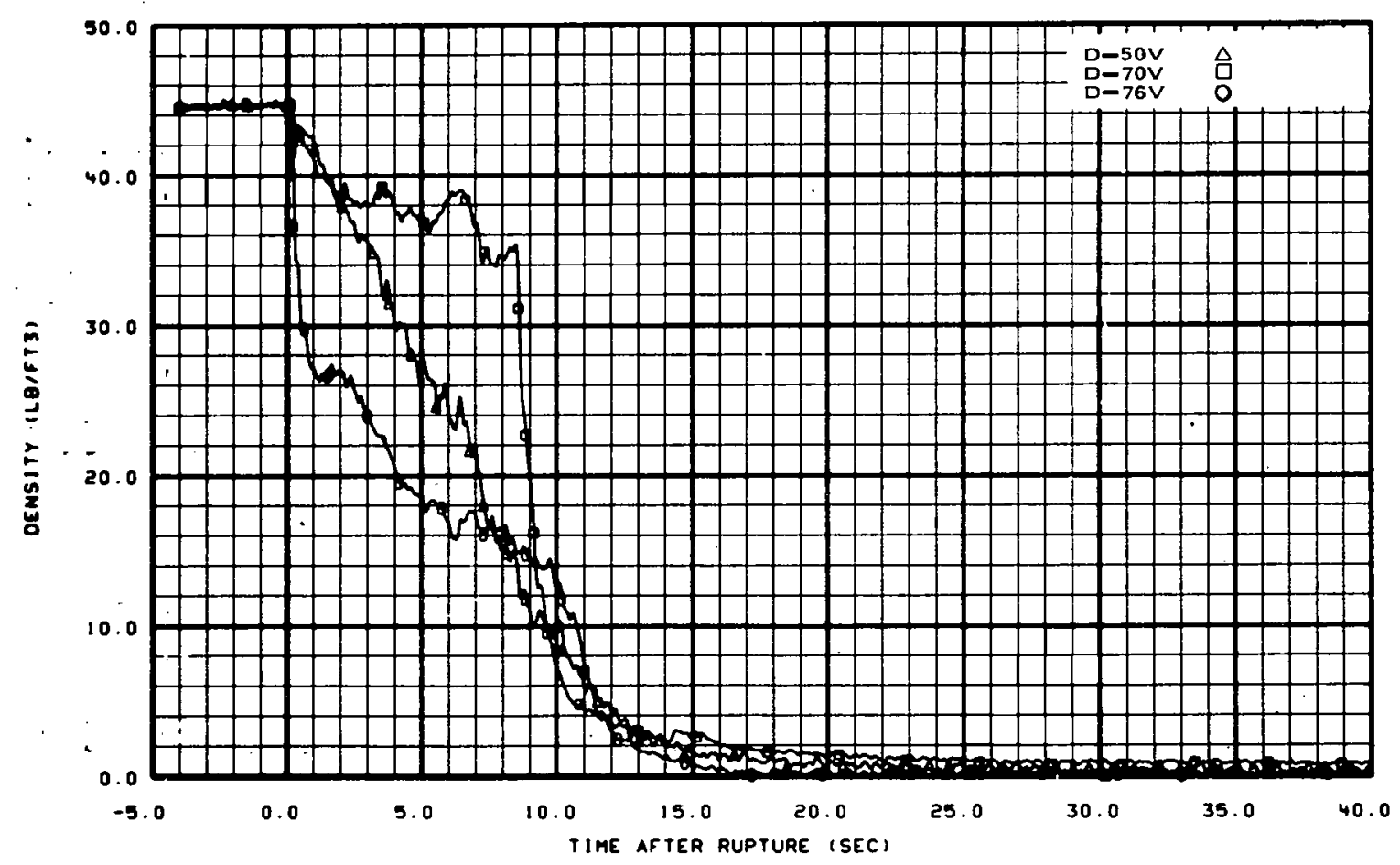

Fig. 100 Fluid density in blowdown loop -- Test 1002. 


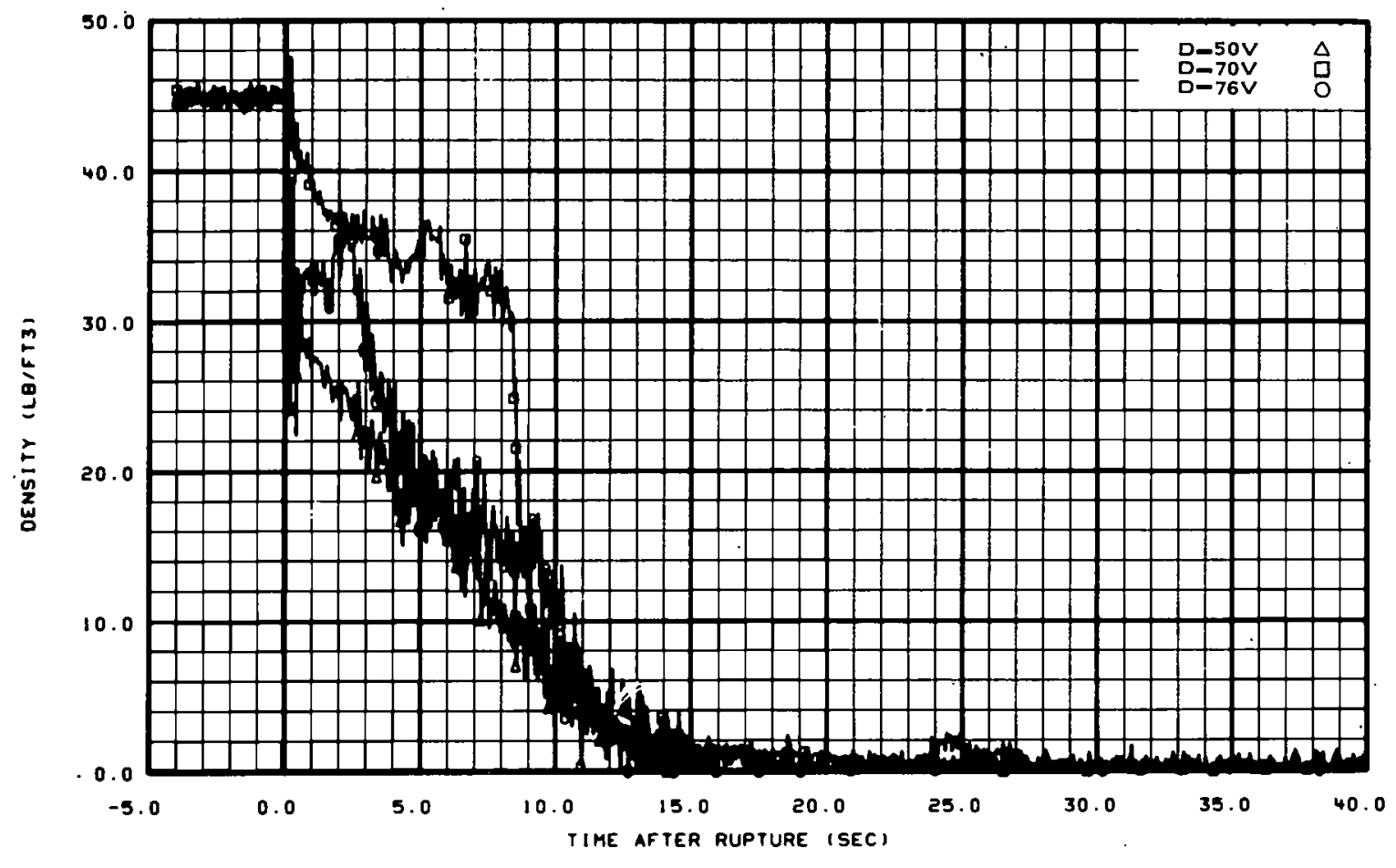

Fig. 101 Fluid density in blowdown loop -- Test 1003.

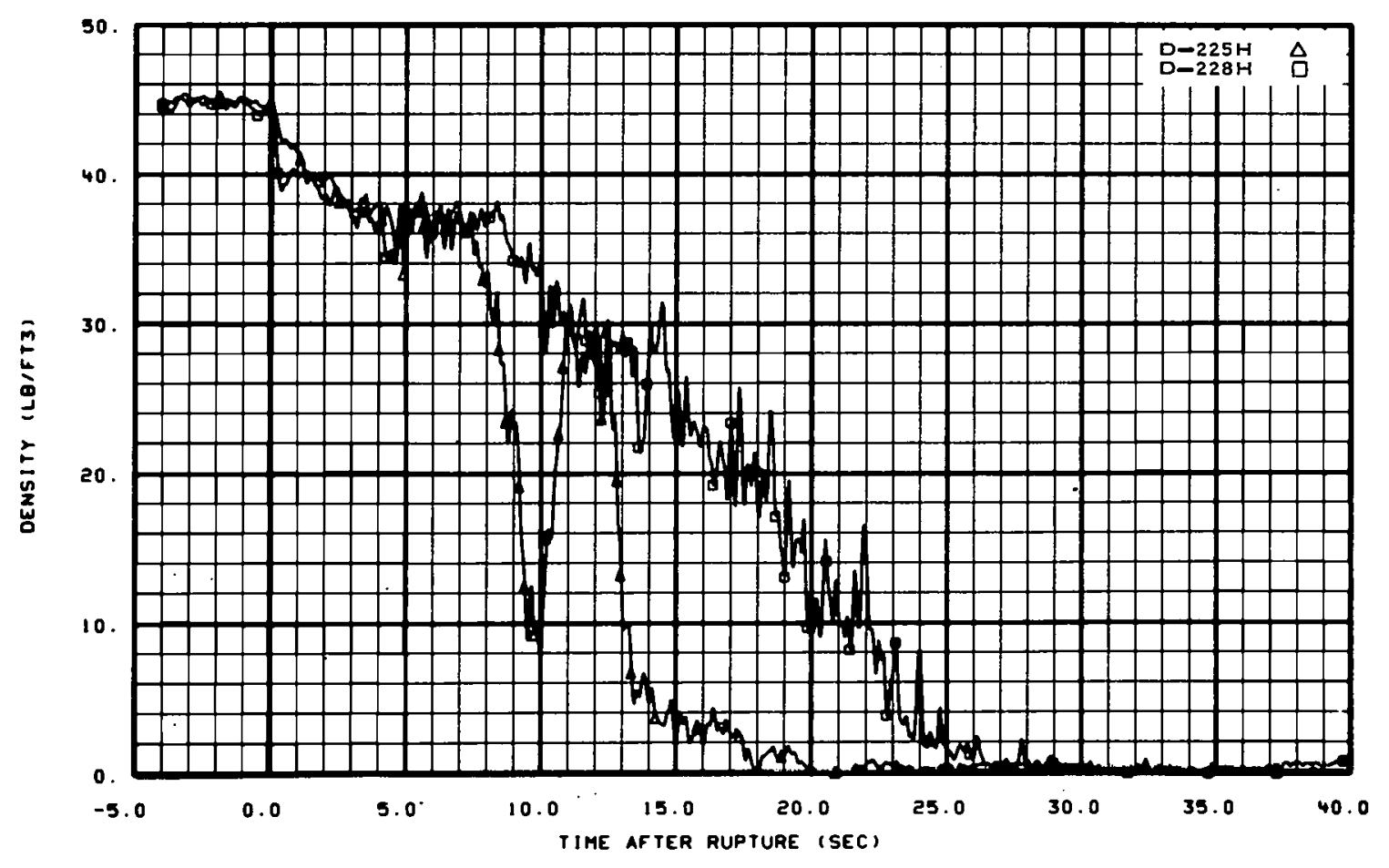

Fig. 102 Fluid density in vessel -- Test 1001. 


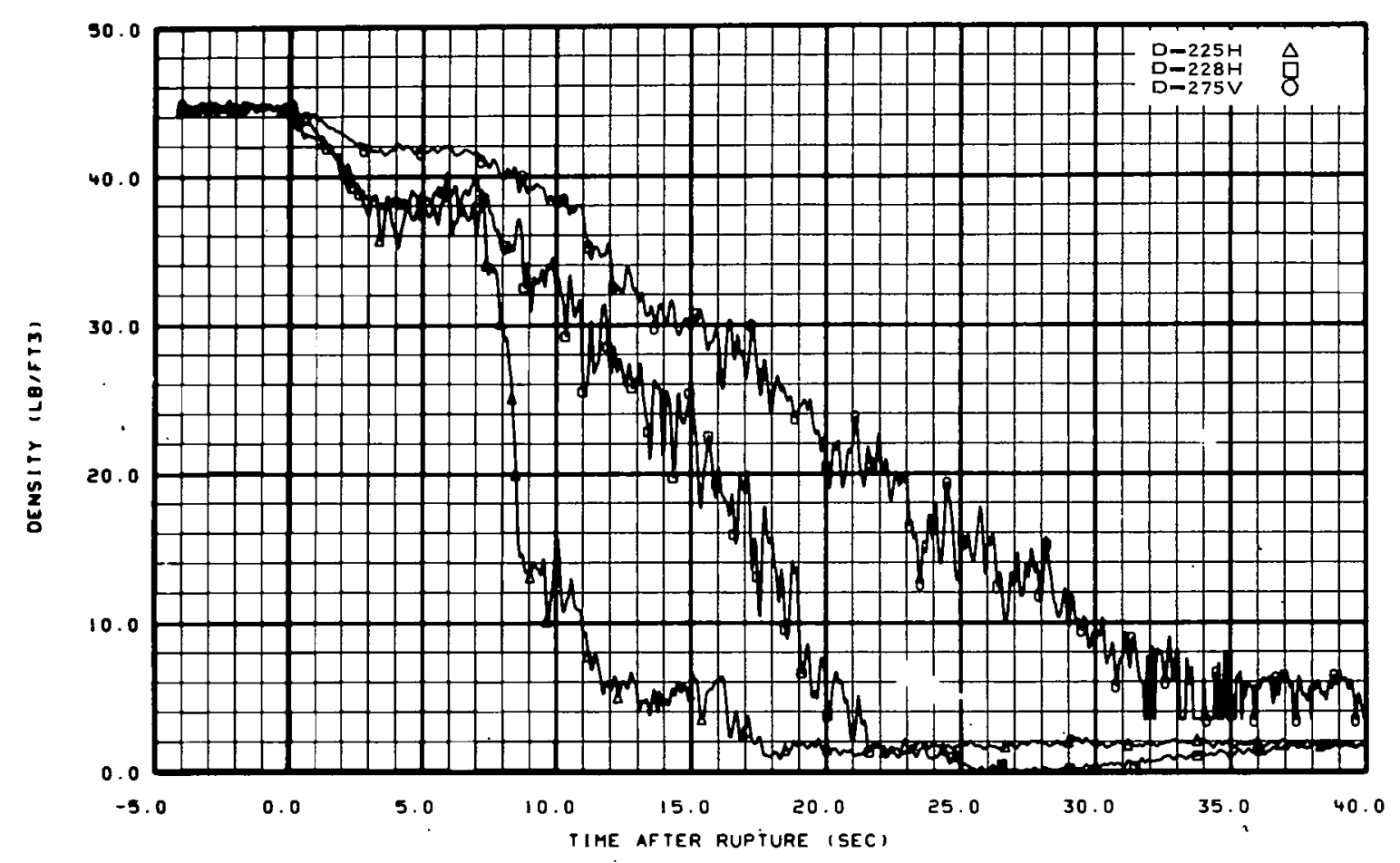

Fig. 103 Fluid density in vessel -- Test 1002.

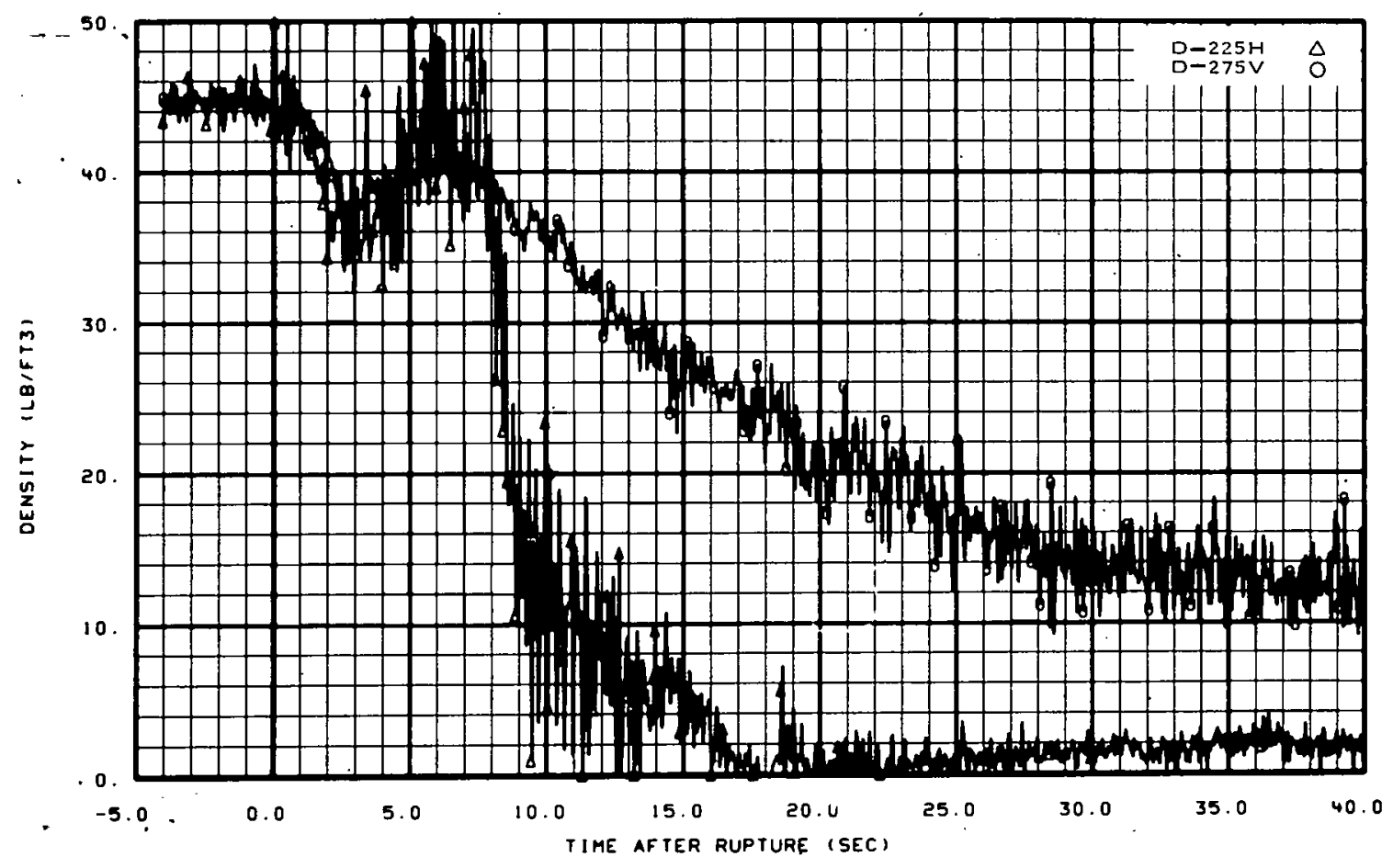

Fig. 104 Fluid density in vessel -- Test 1003. 


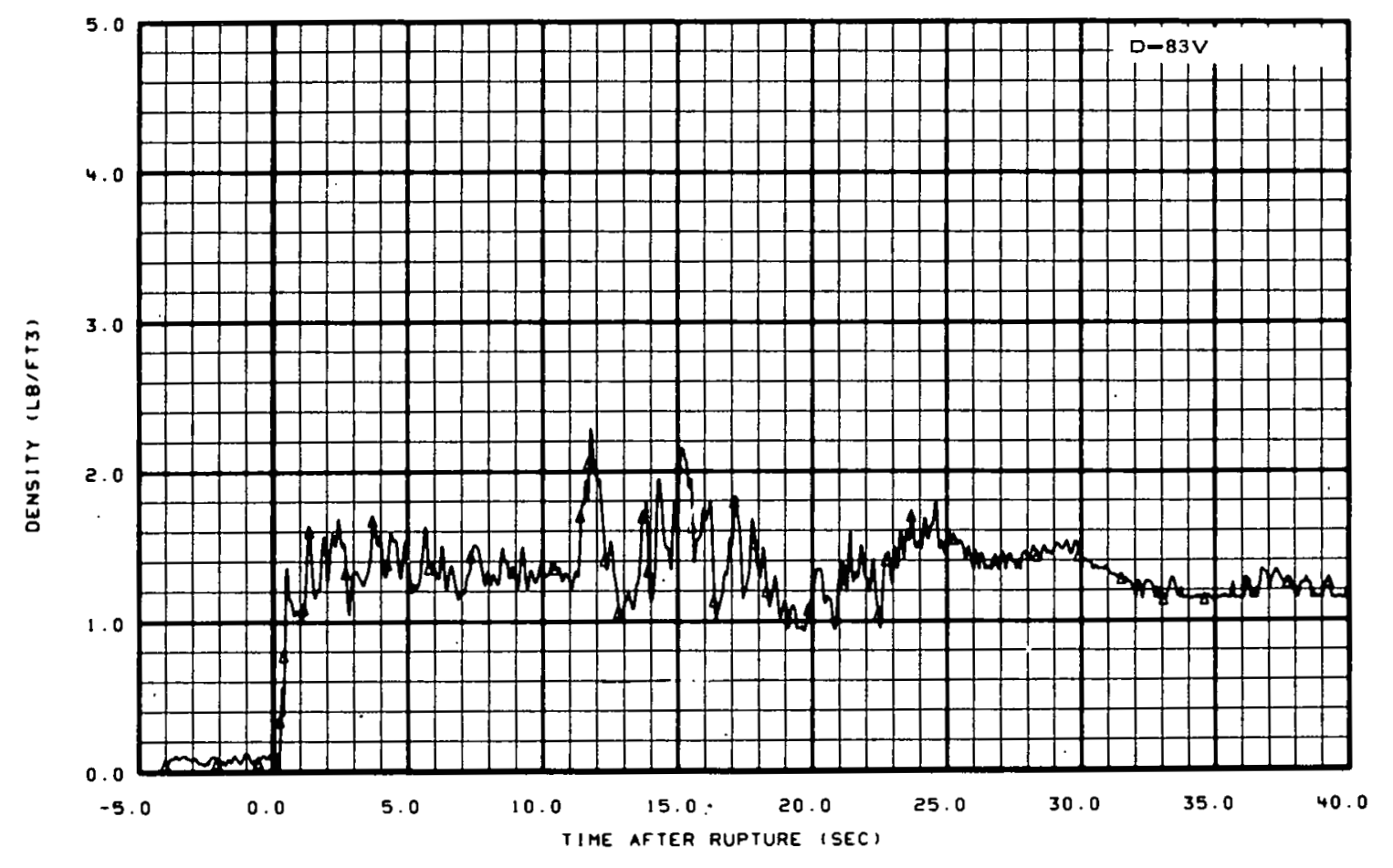

Fig. 105 Fluid density in pressure suppression header -- Test 1001.

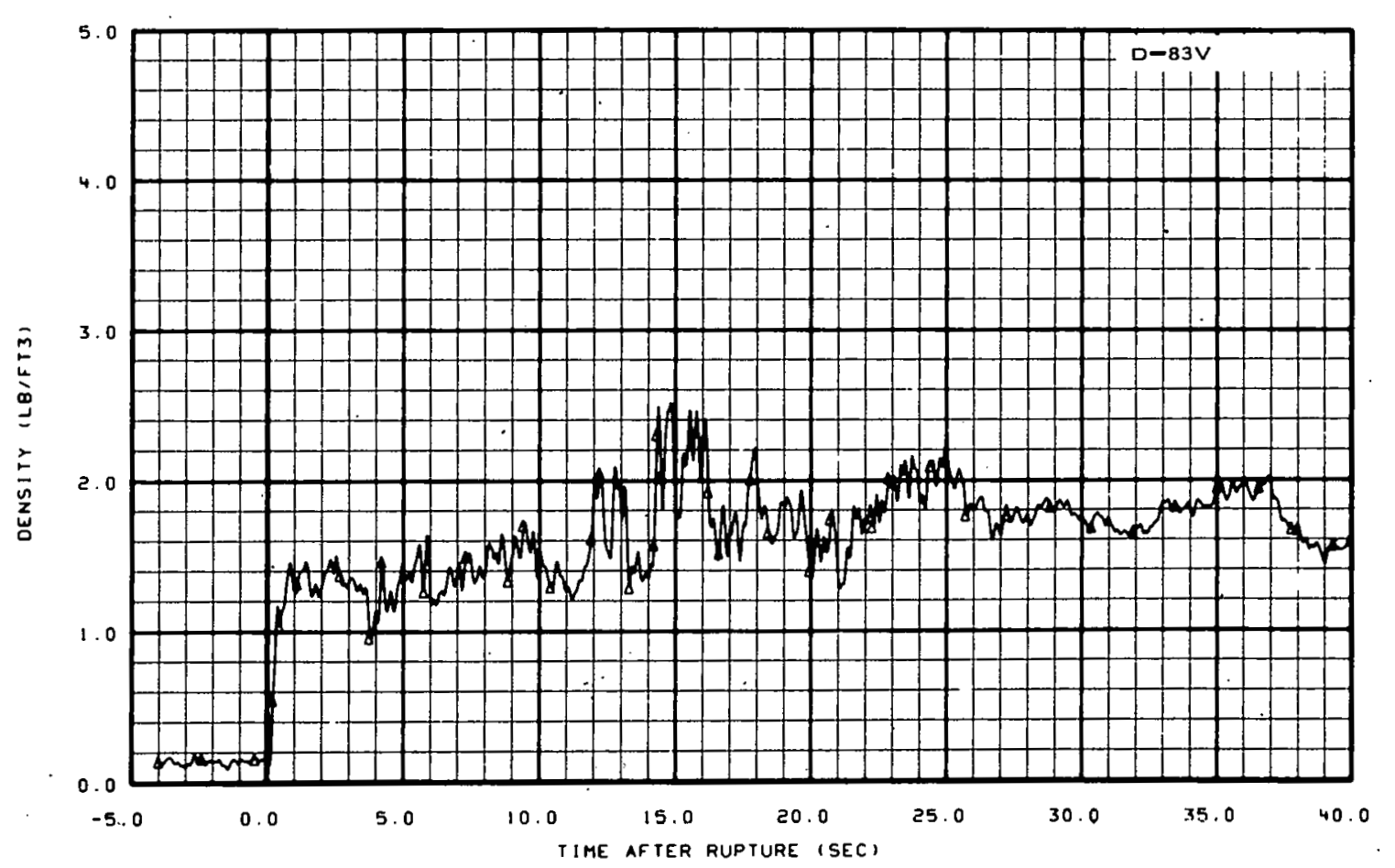

Fig. 106 Fluid density in pressure suppression header -- Test 1002 . 


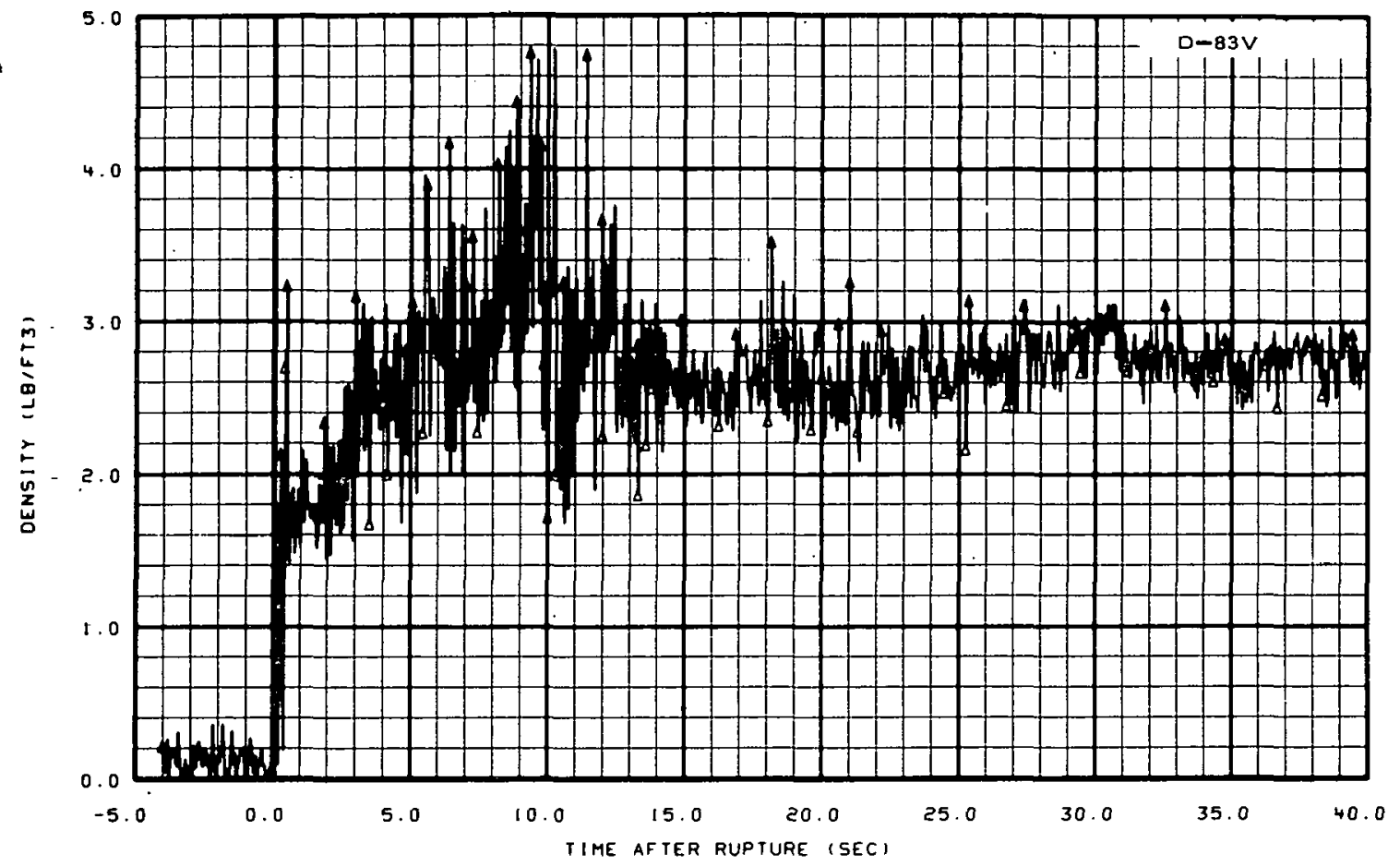

Fig. 107 Fluid density in pressure suppression header -- Test 1003.

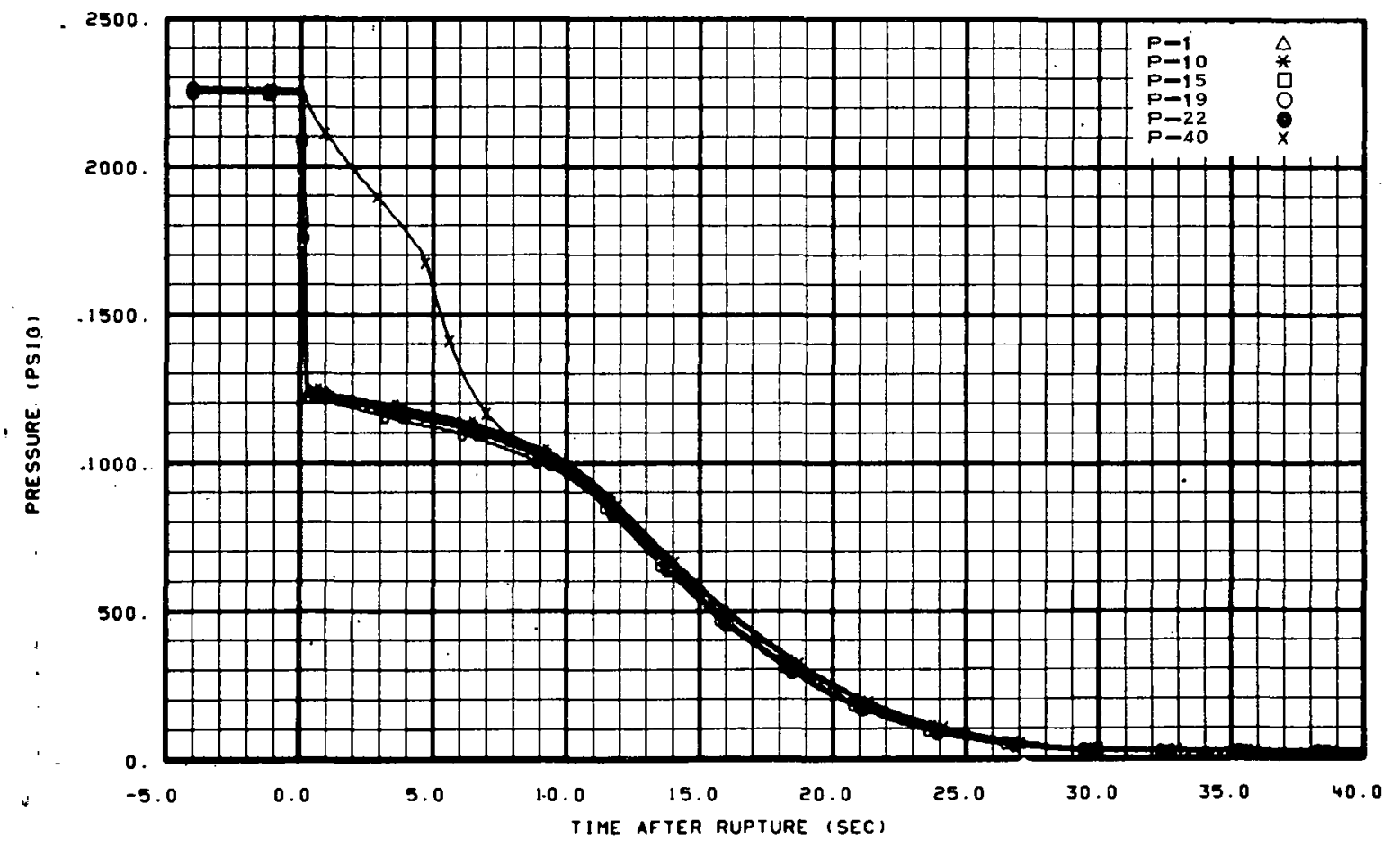

. Fig. 108 Pressure in operating loop -- Test 1001. 


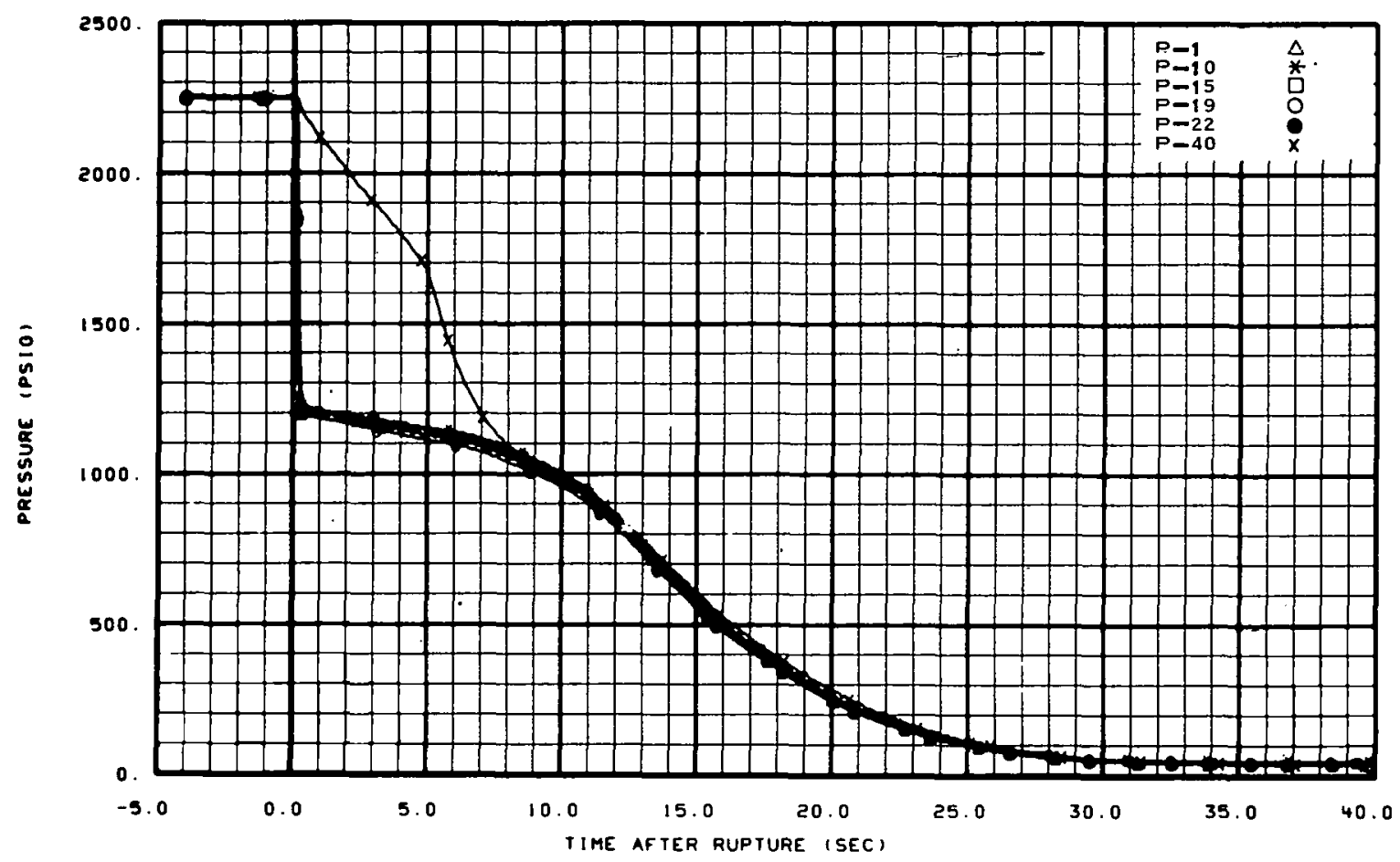

Fig. 109 Pressure in operating loop -- Test 1002.

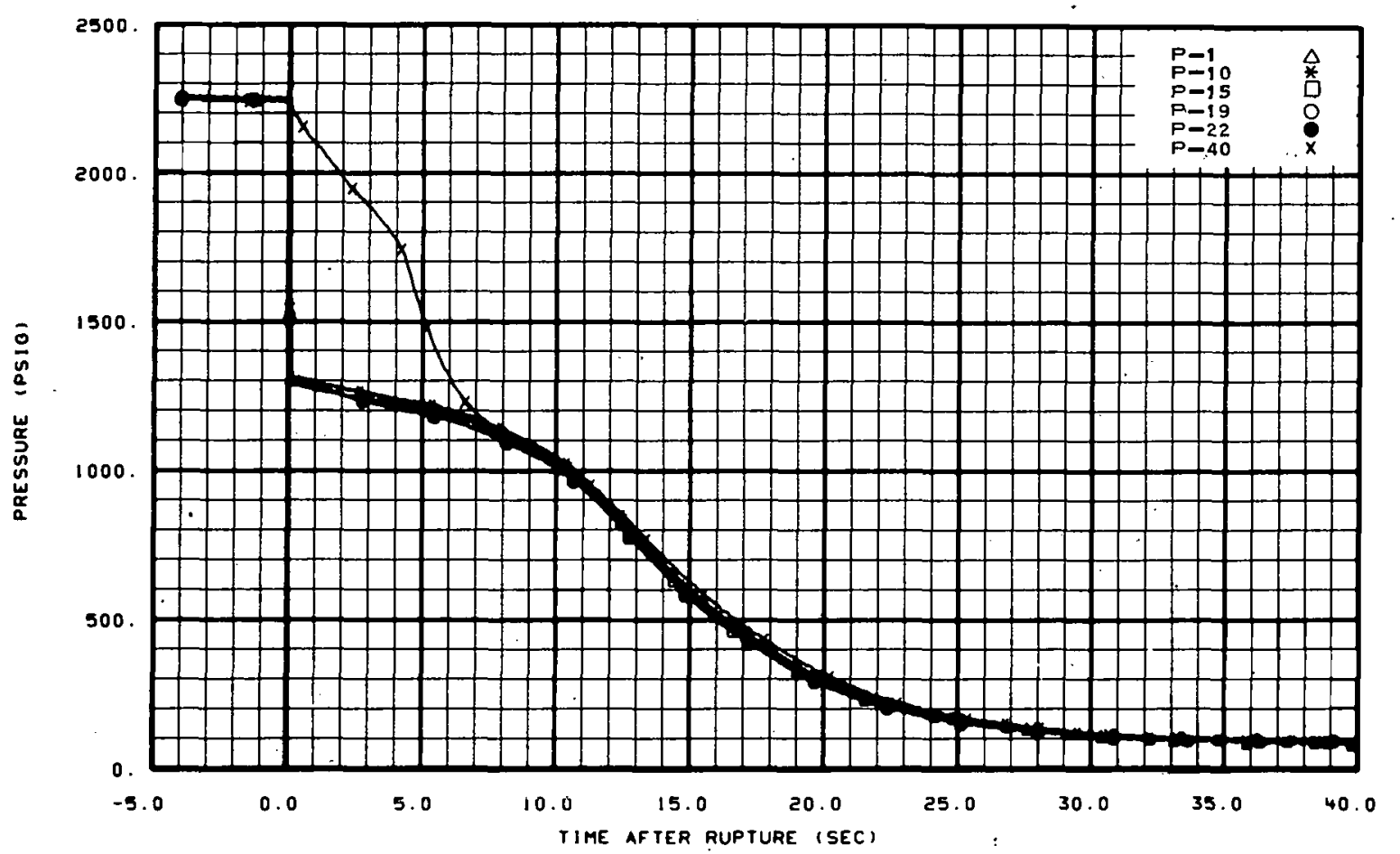

Fig. 110 Pressure in operating loop -- Test 1003. 


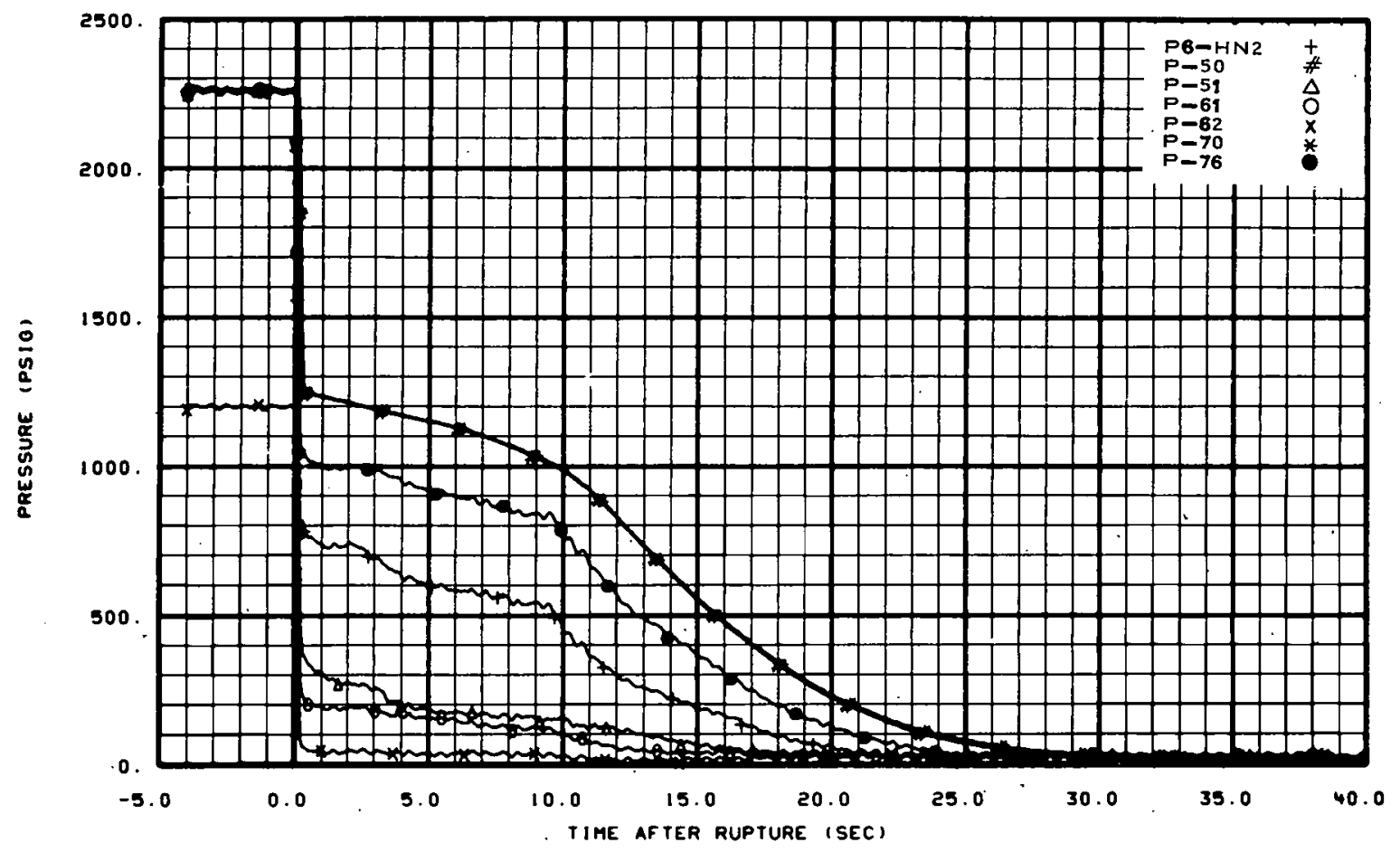

Fig. 111 Pressure in blowdown loop -- Test 1001.

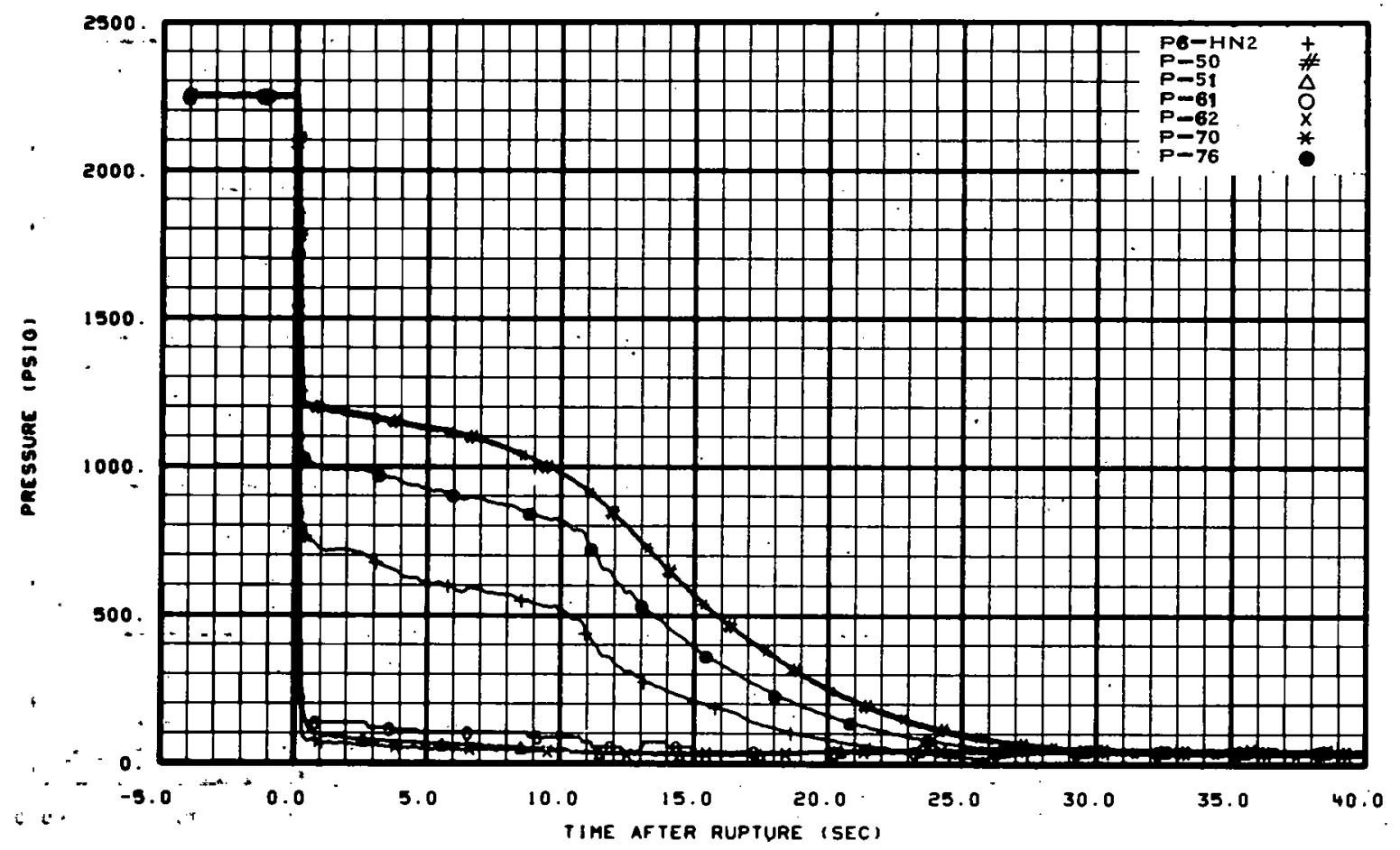

Fig. 112 Pressure in blowdown loop -- Test 1002. 


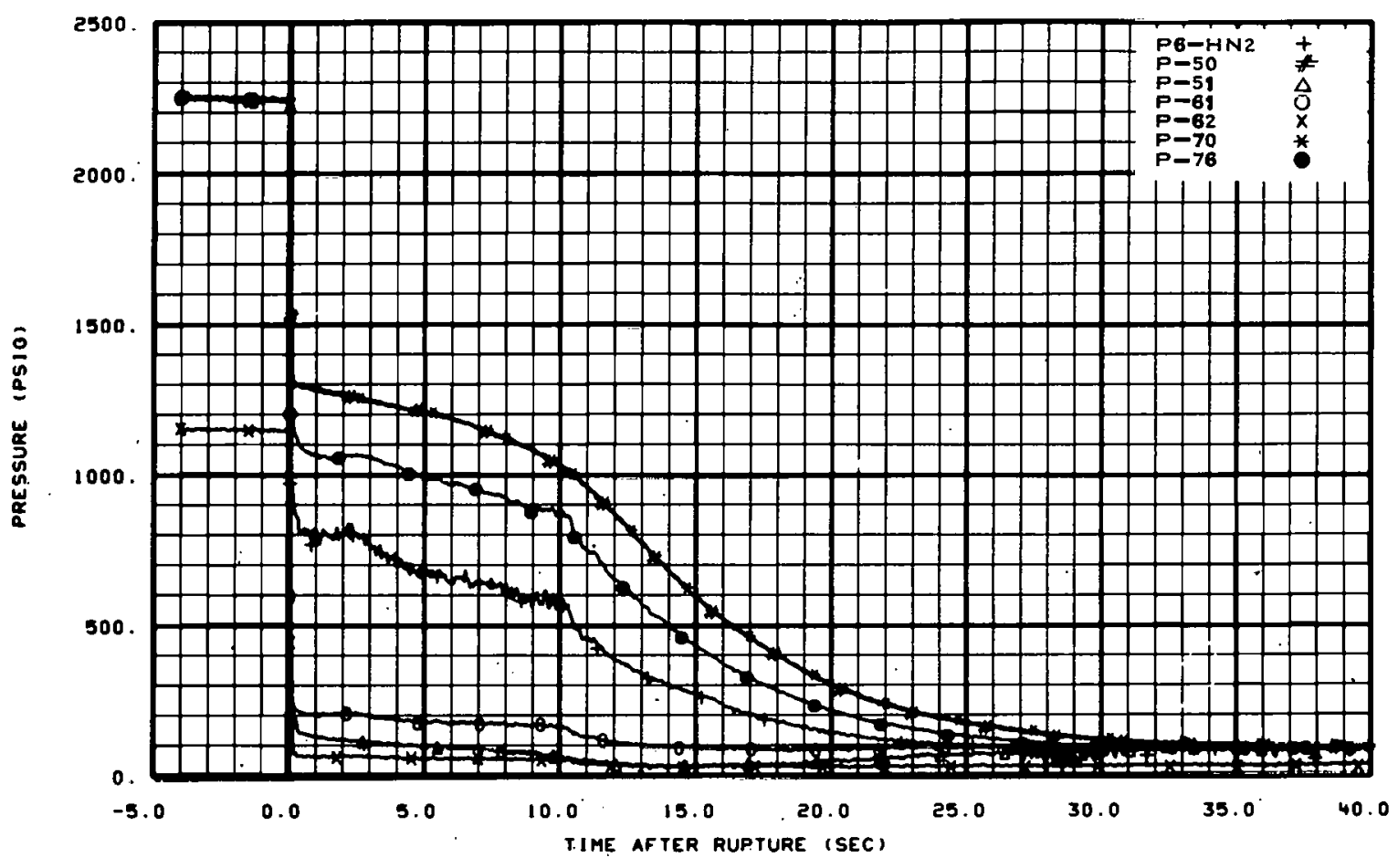

Fig. 113 Pressure in blowdown loop -- Test 1003.

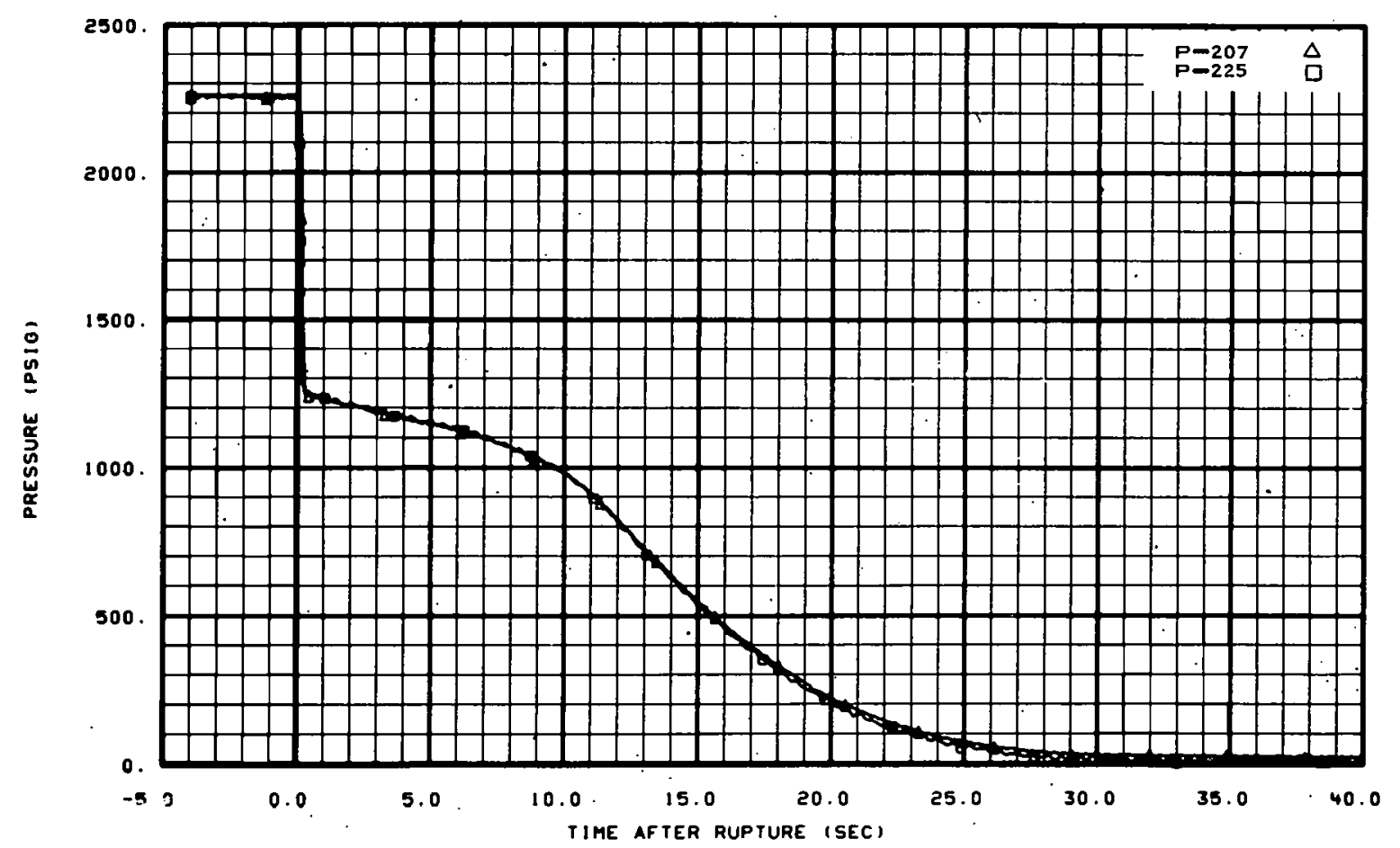

Fig. 114 Pressure in vessel -- Test 1001. 


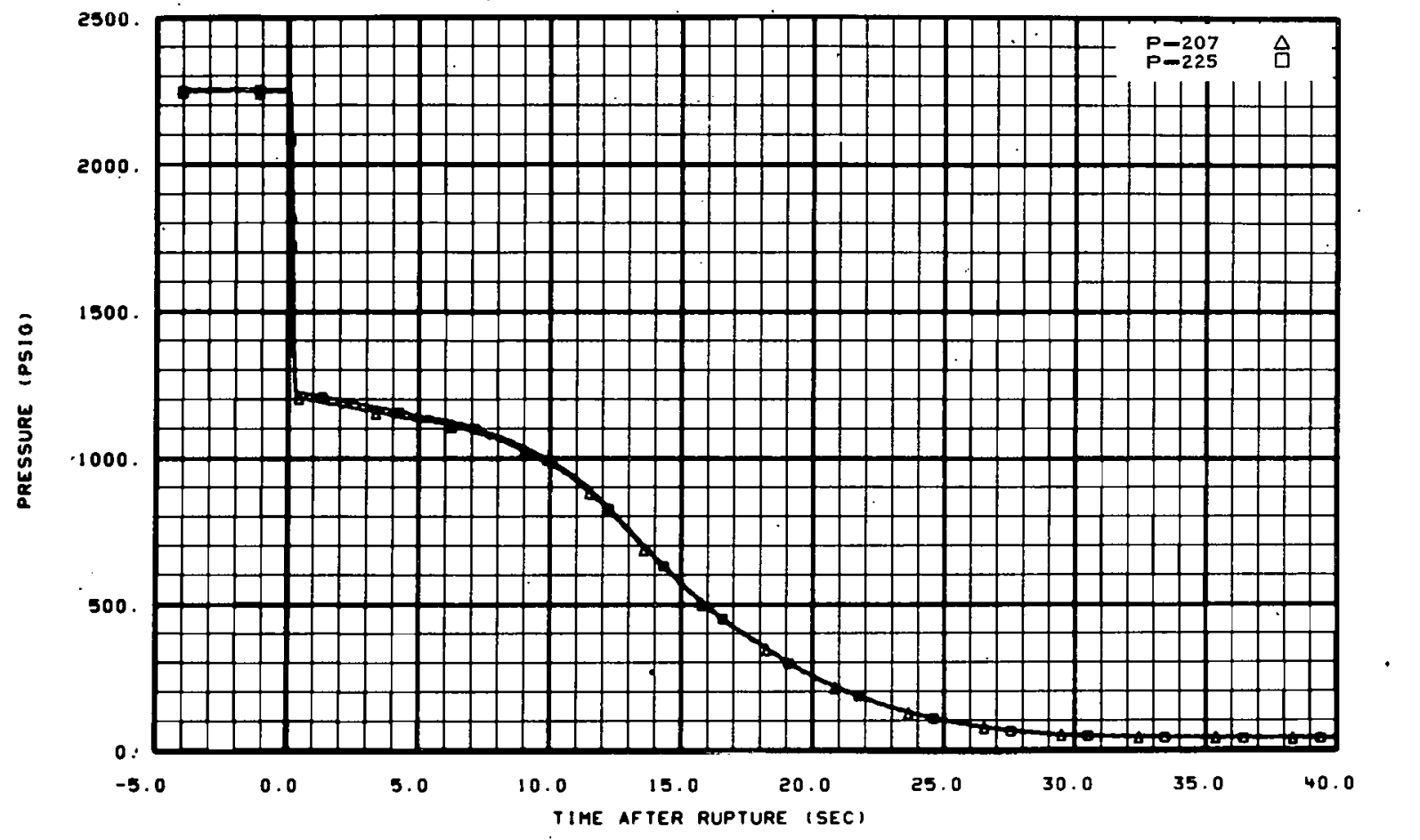

Fig. 115 Pressure in vessel -- Test 1002.

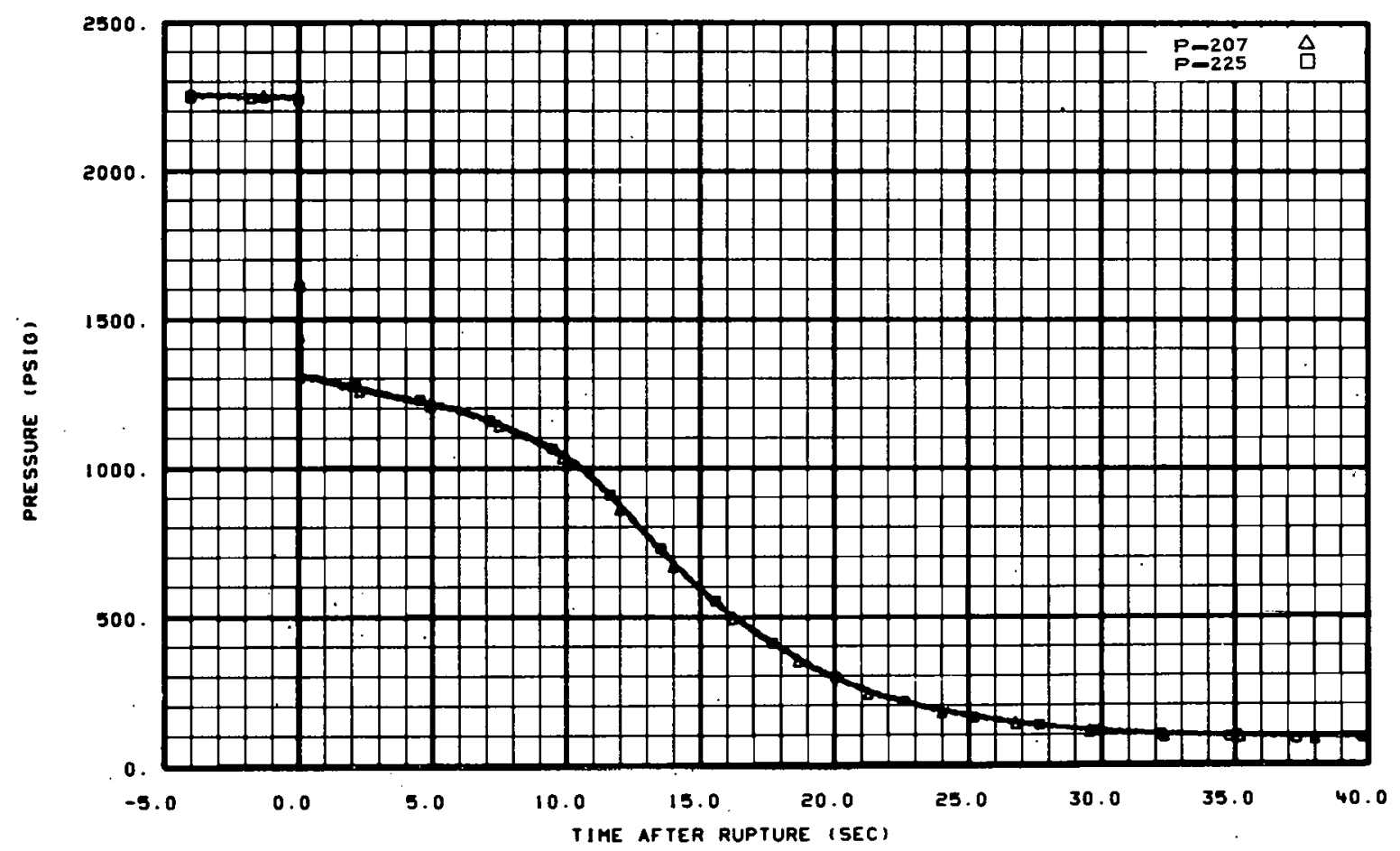

Fig. 116 Pressure in vessel -- Test 1003. 


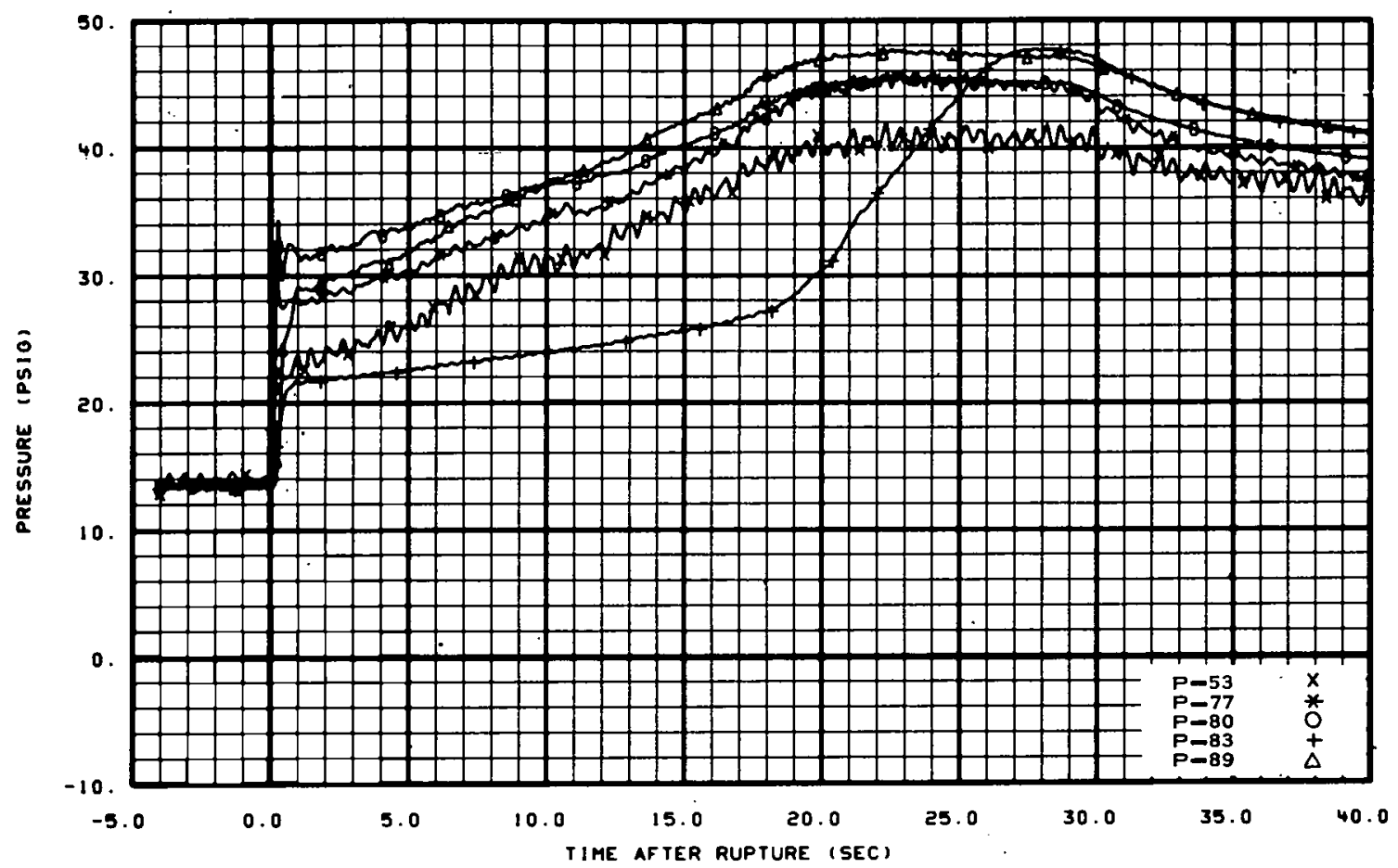

Fig. 117 Pressure in pressure suppression system -- Test 1001.

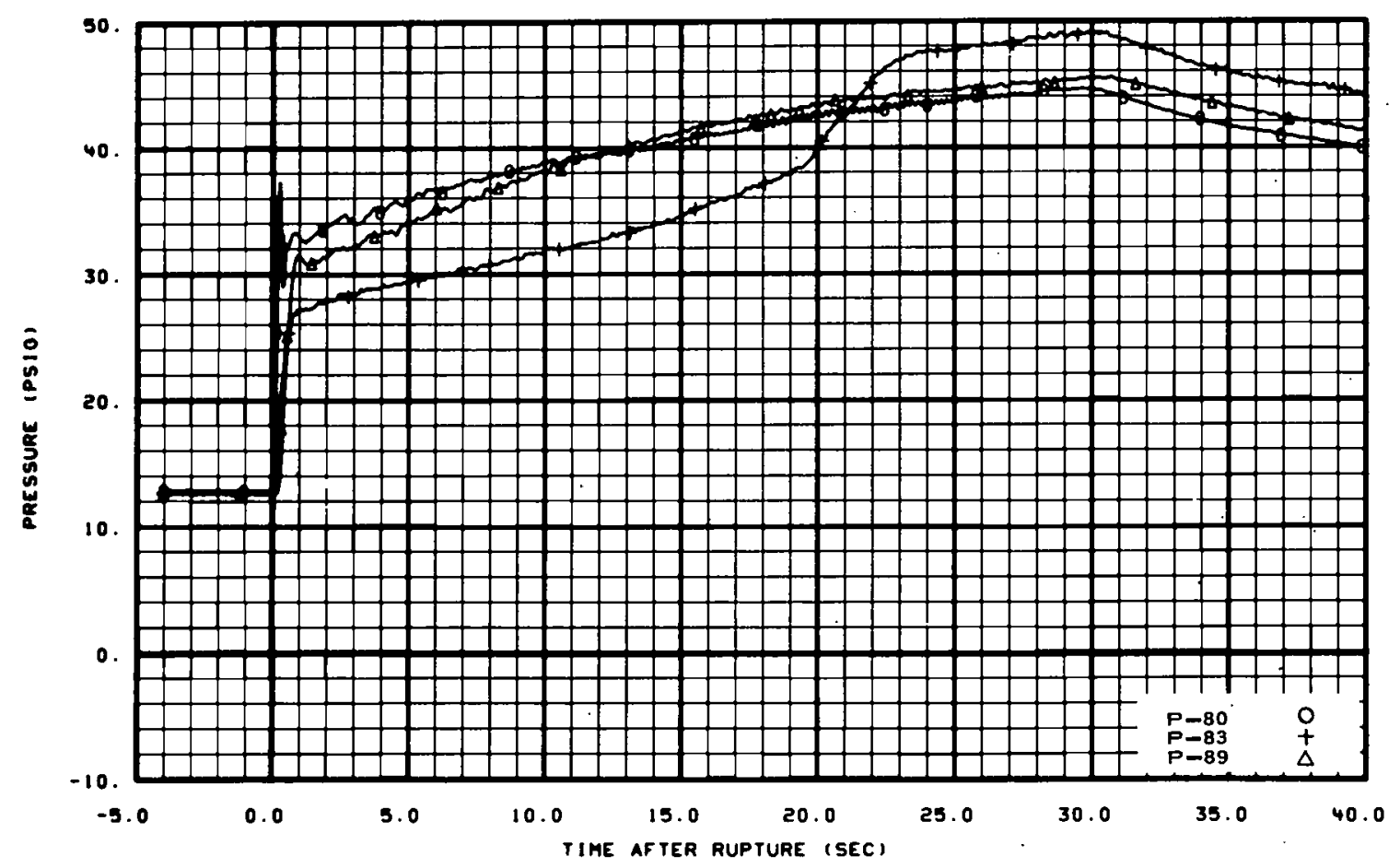

Fig. 118 Pressure in pressure suppression system -- Test 1002. 


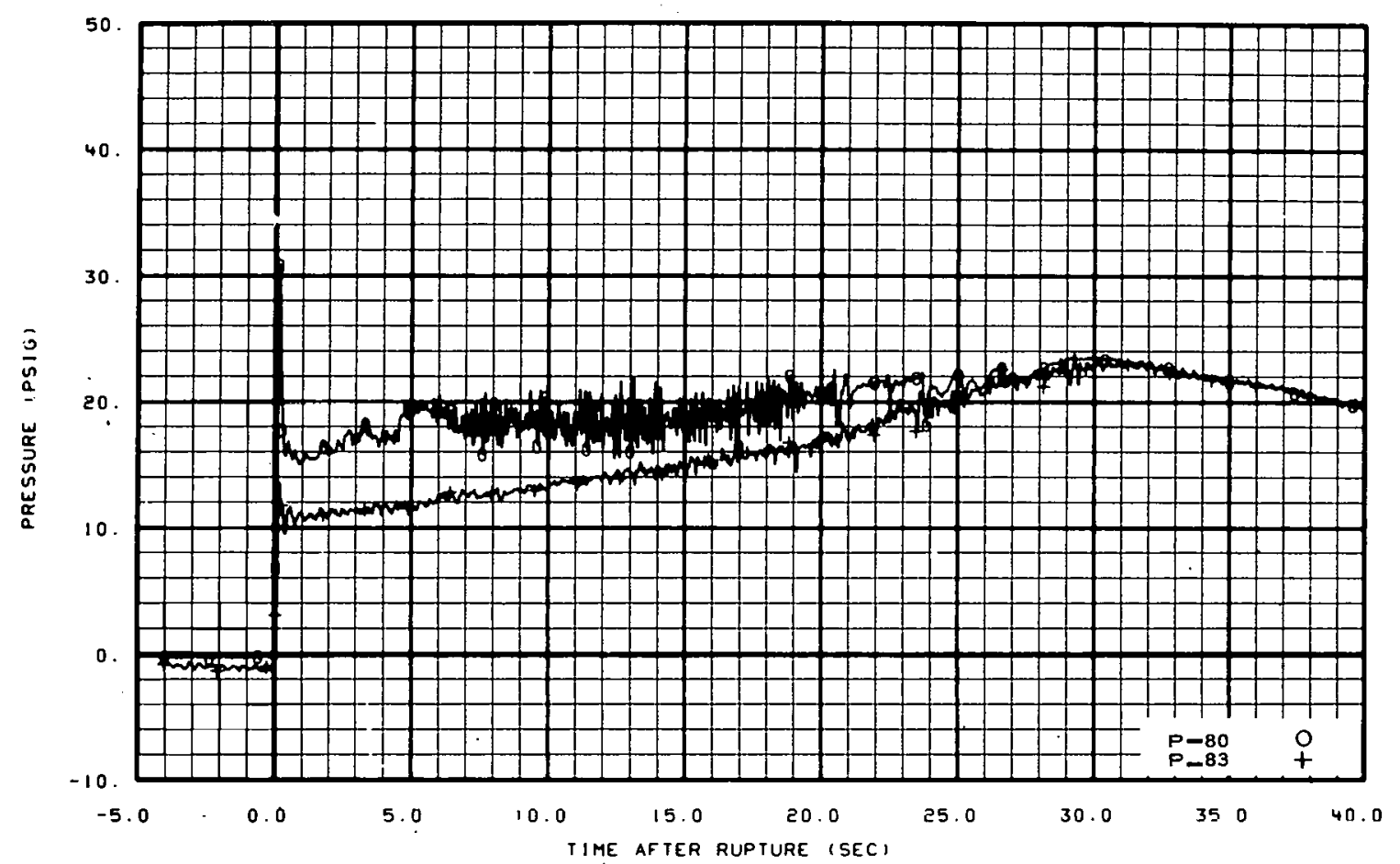

Fig. 119 Pressure in pressure suppression system -- Test 1003 (P-80 and $\mathrm{P}-83)$.

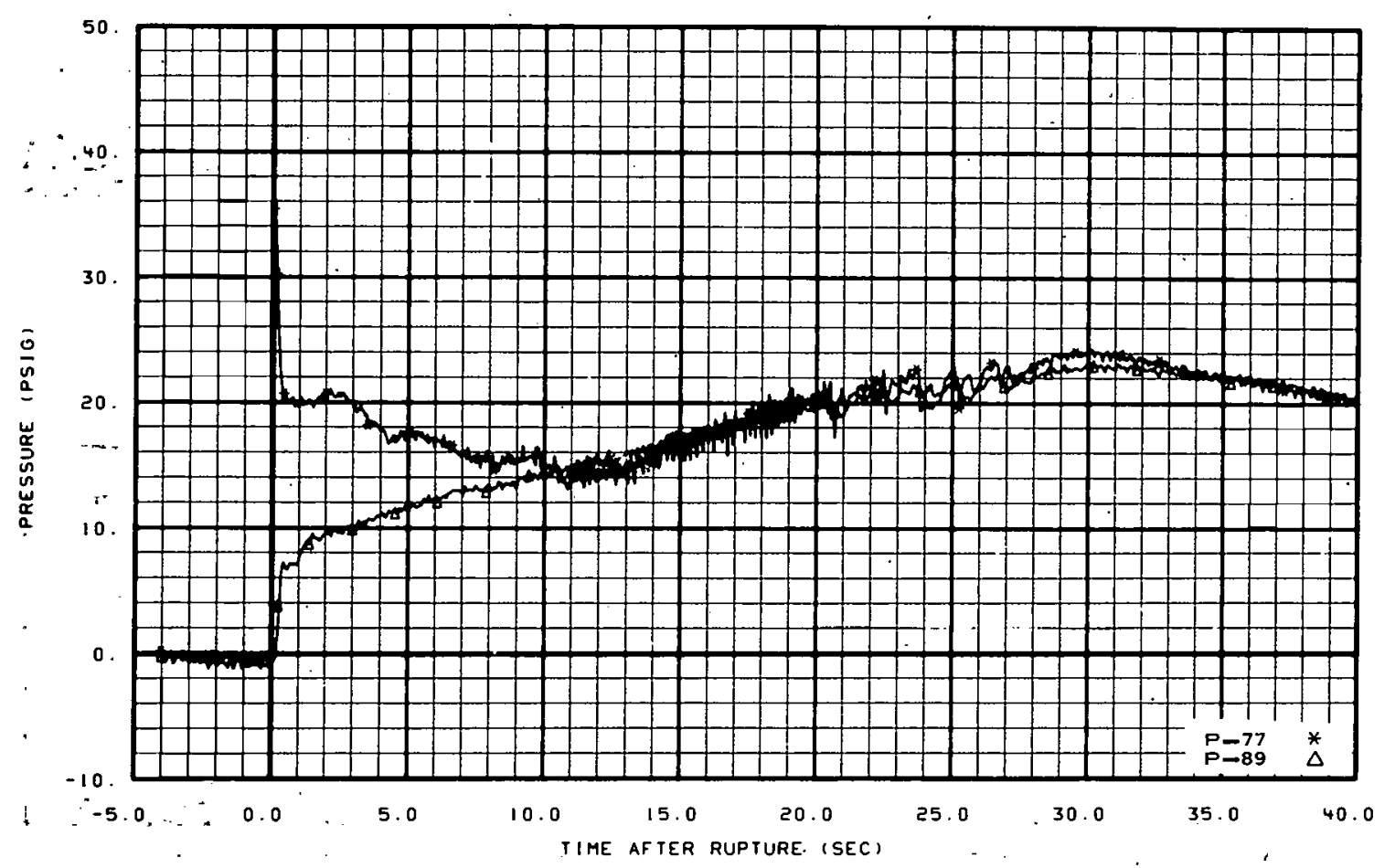

Fig. 120 Pressure in pressure suppression system -- Test 1003 (P-77 and $\mathrm{P}-89)$. 


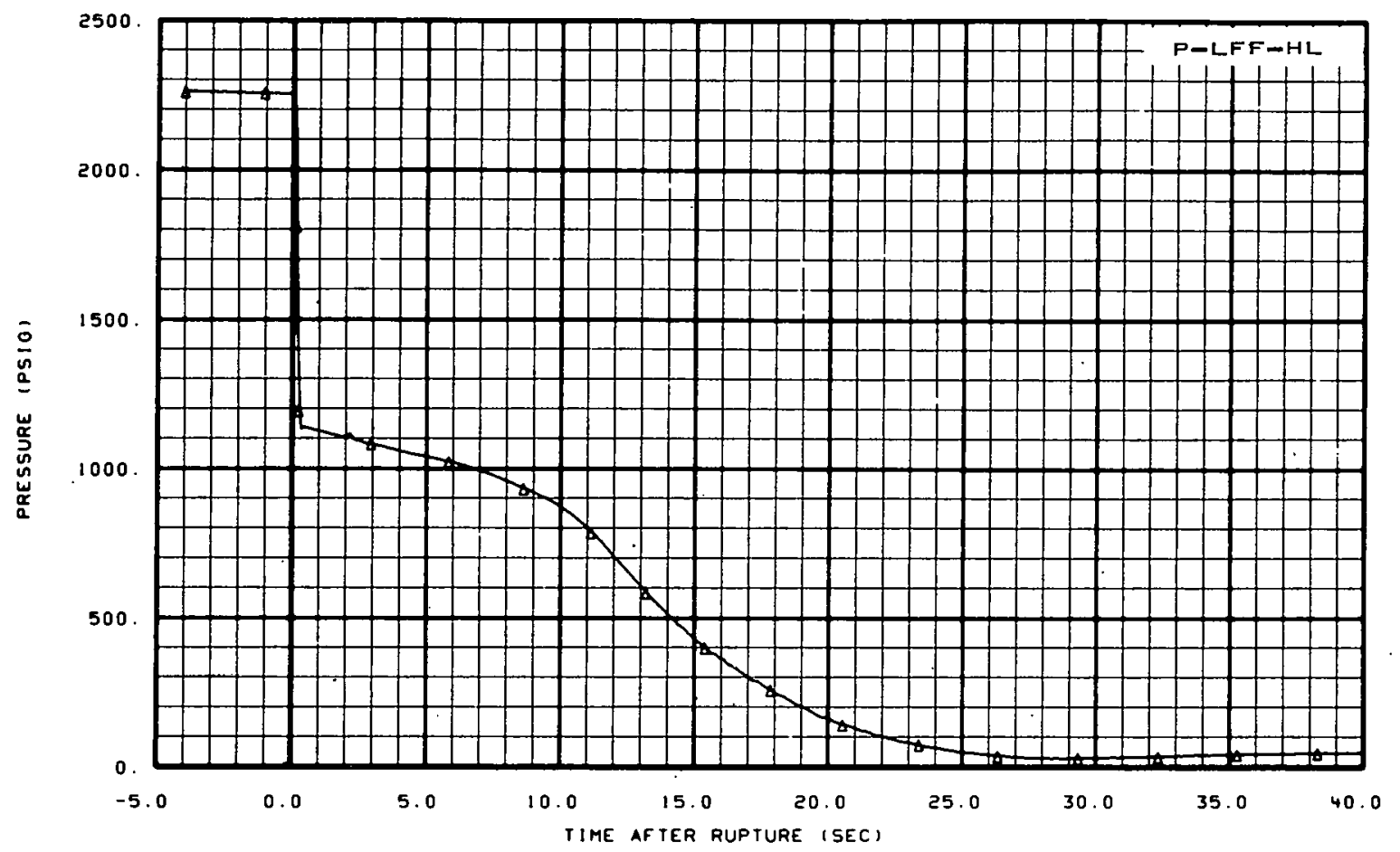

Fig. 121 Pressure at hot leg stub in upper plenum (LOFT free field pressure transducer) -- Test 1001 .

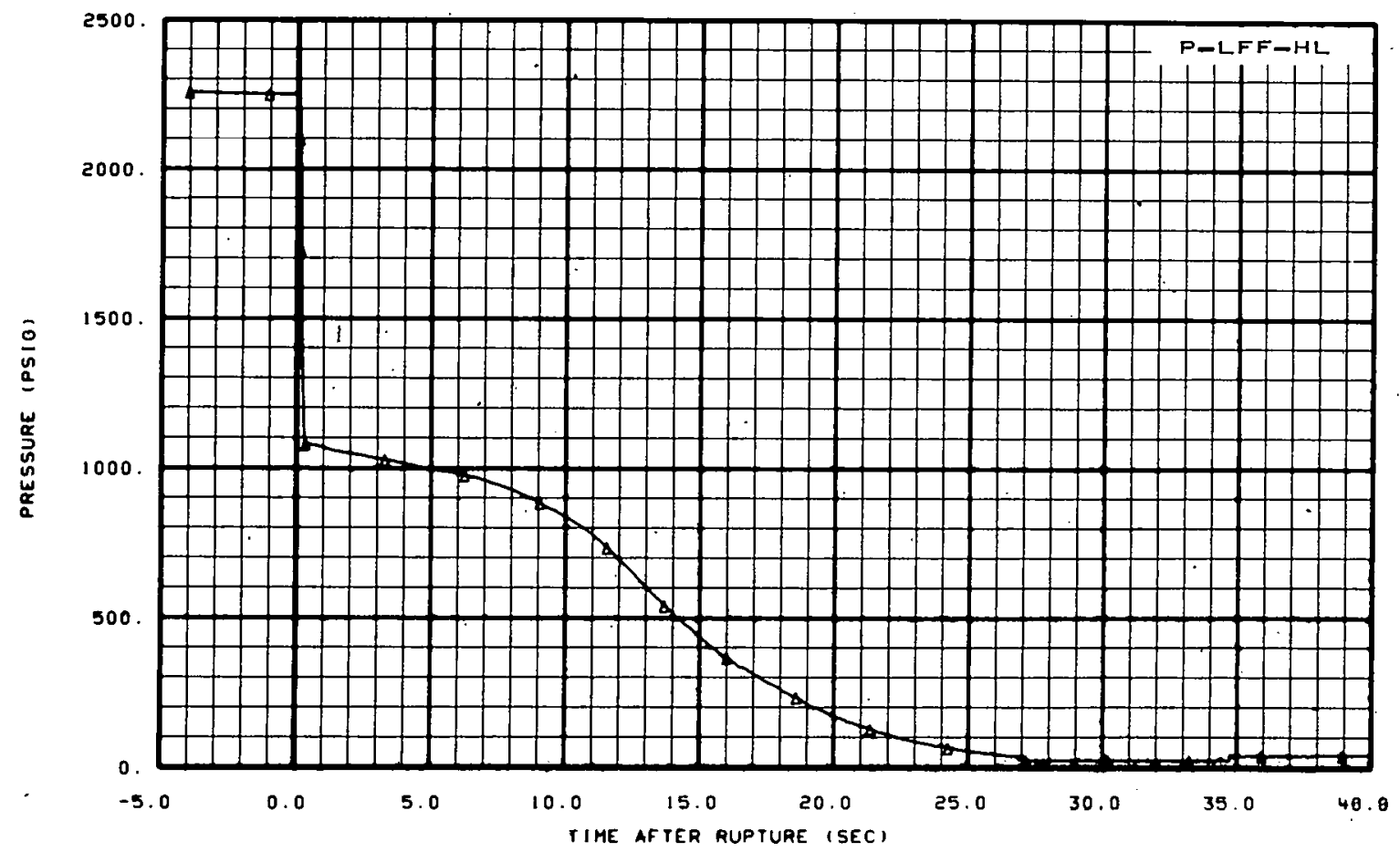

Fig. 122 Pressure at hot leg stub in upper plenum (LOFT free field pressure transducer) -- Test 1002 . 


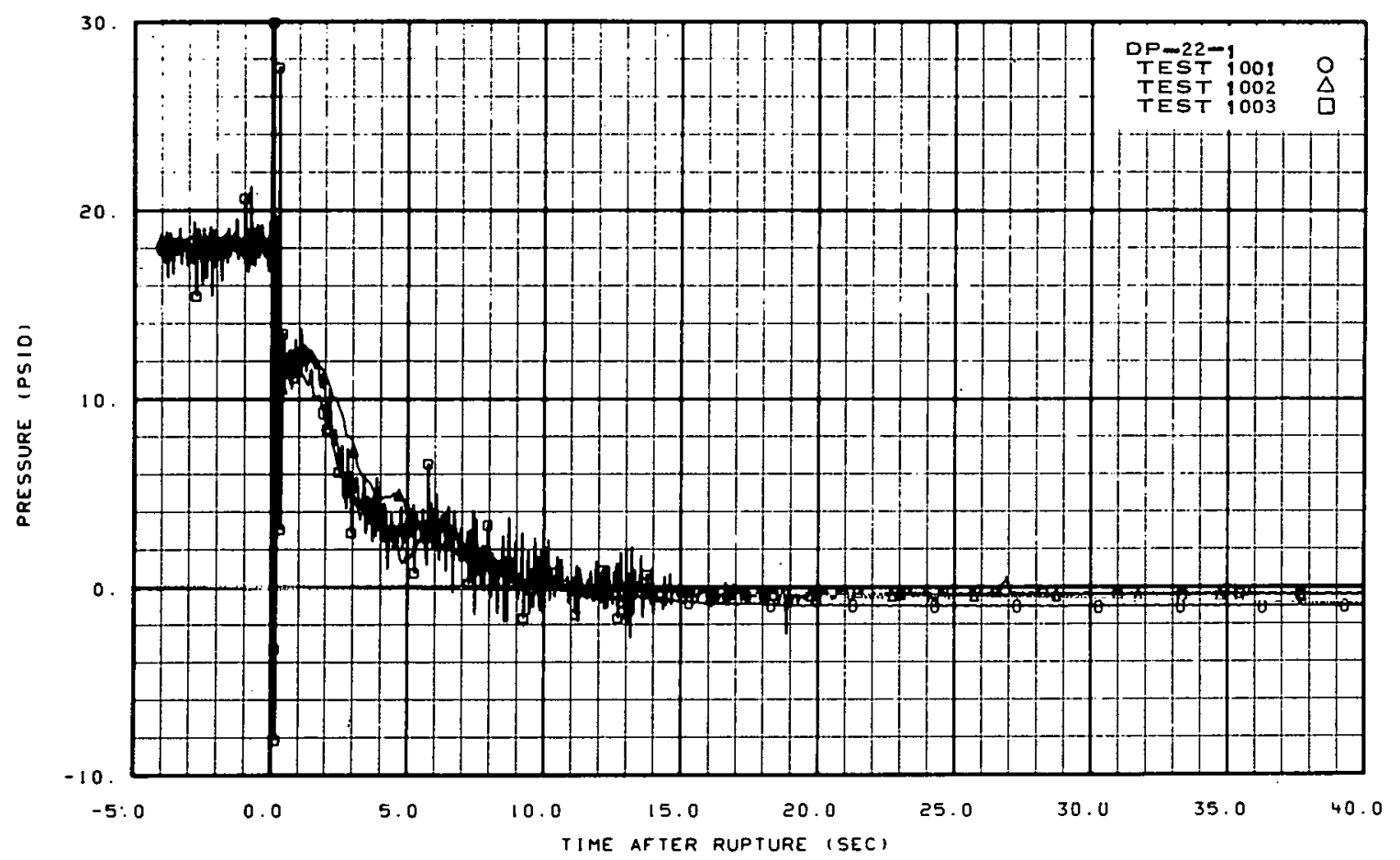

Fig. 123 Differential pressure across operating loop (DP-22-1) -- Tests 1001,1002 , and 1003.

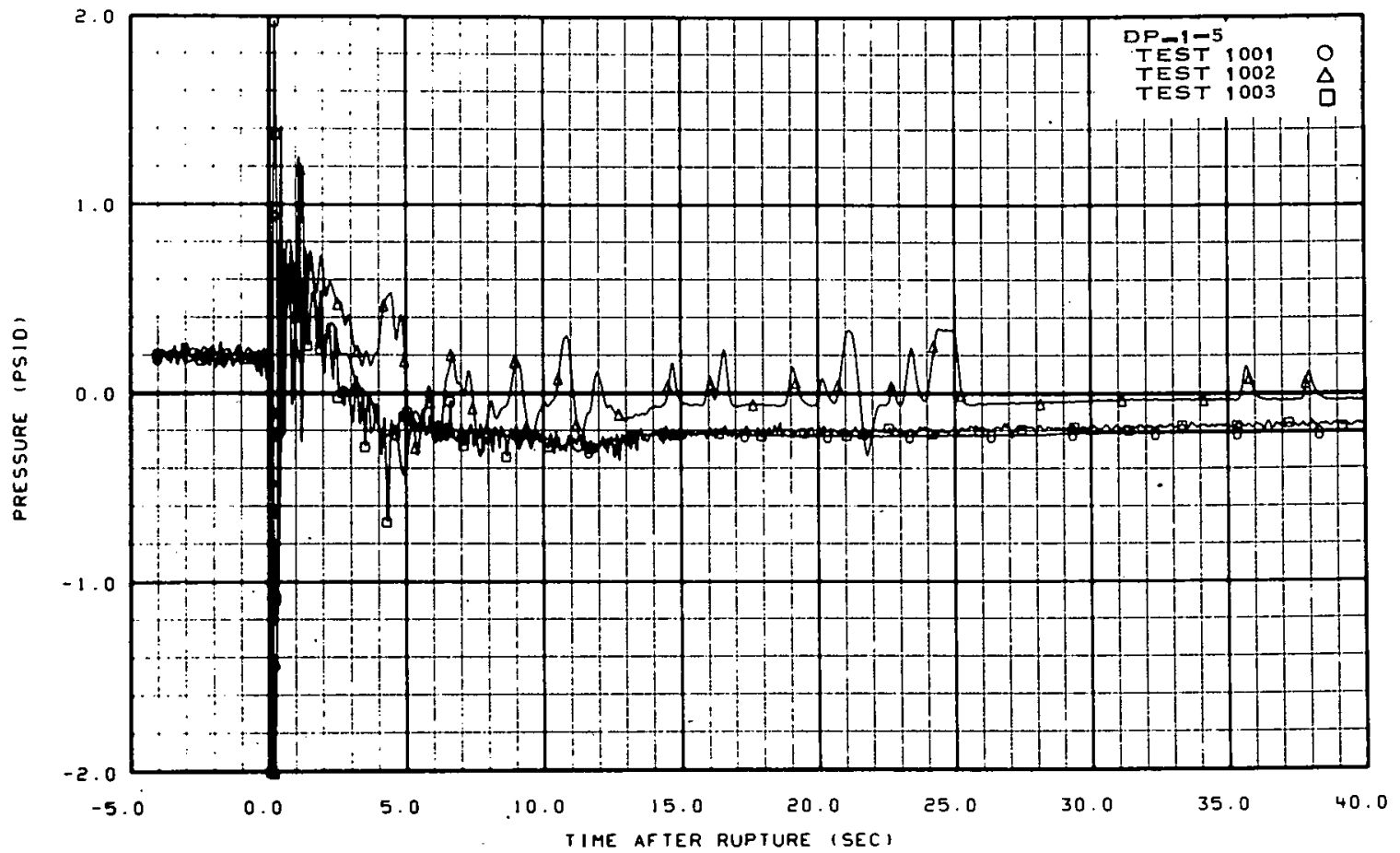

Fig. 124 Differential pressure, operating loop hot leg (DP-1-5) -- Tests 1001,1002 , and 1003. 


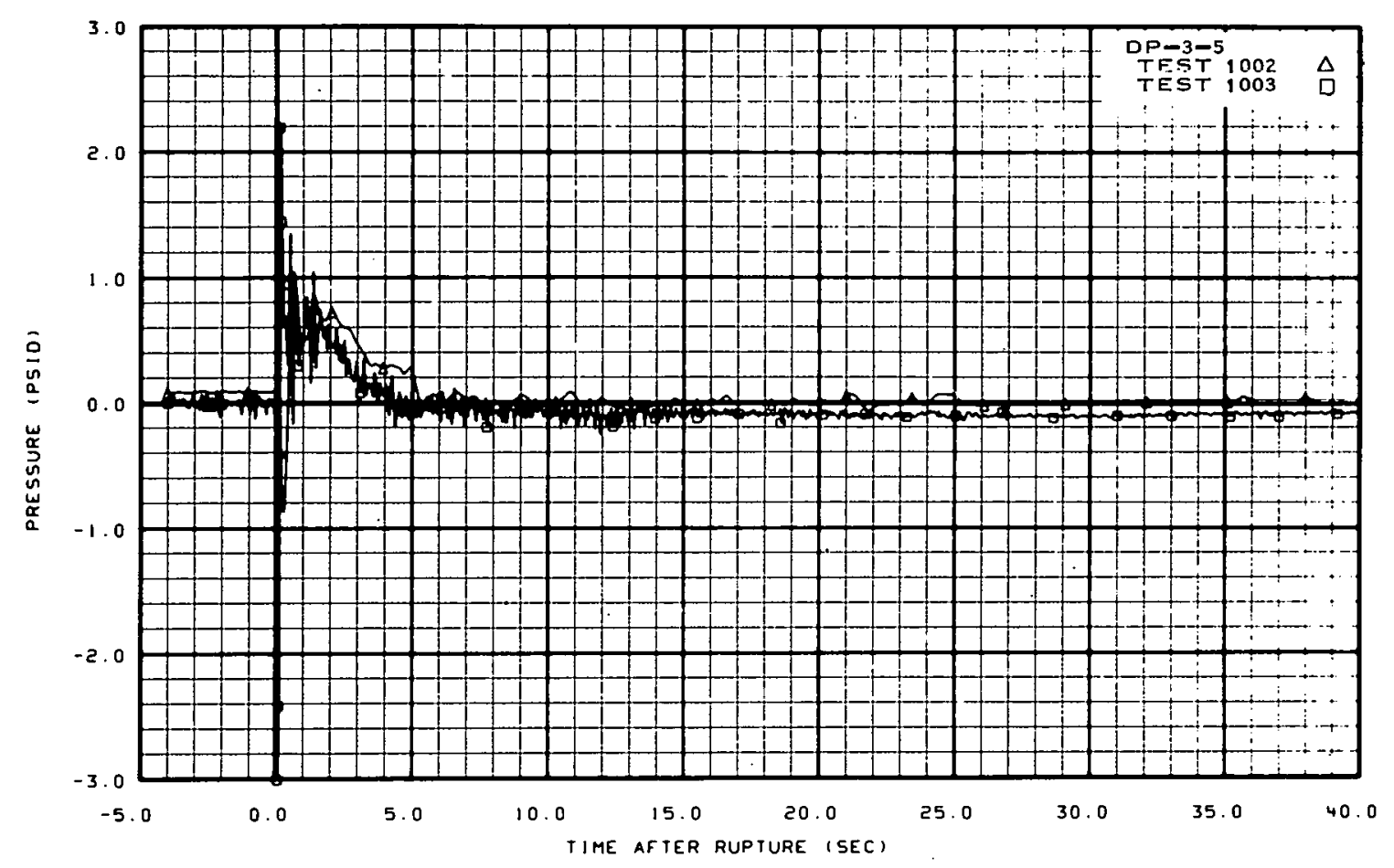

Fig. 125 Differential pressure, operating loop hot leg (DP-3-5) -- Tests 1002. and 1003.

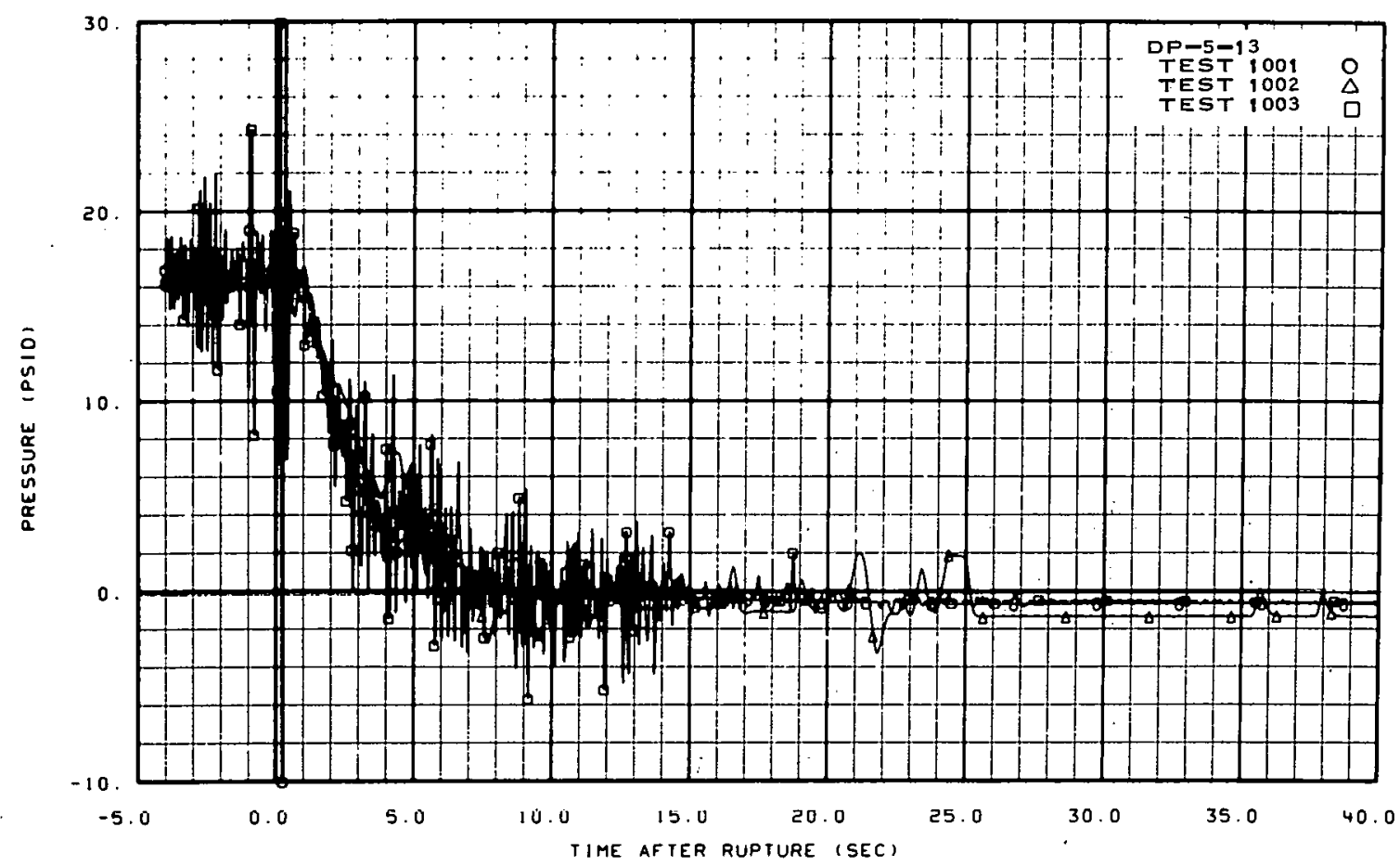

Fig. 126 Differential pressure across steam generator. (DP-5-13) -- Tests 1001,1002 , and 1003. 


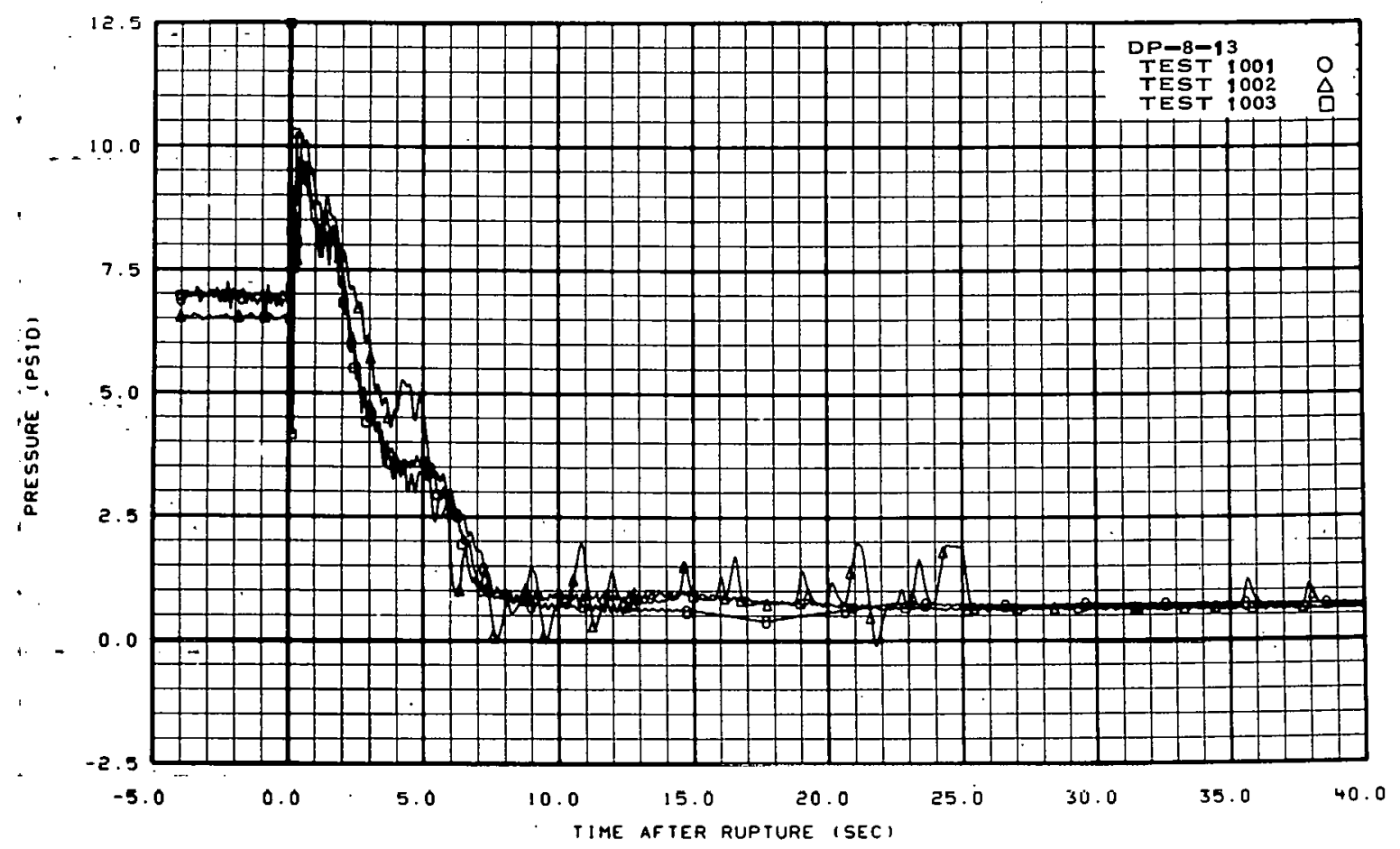

Fig. 127 Differential pressure across pump suction orifice (DP-8-13) -Tests 1001, 1002, and 10n3.

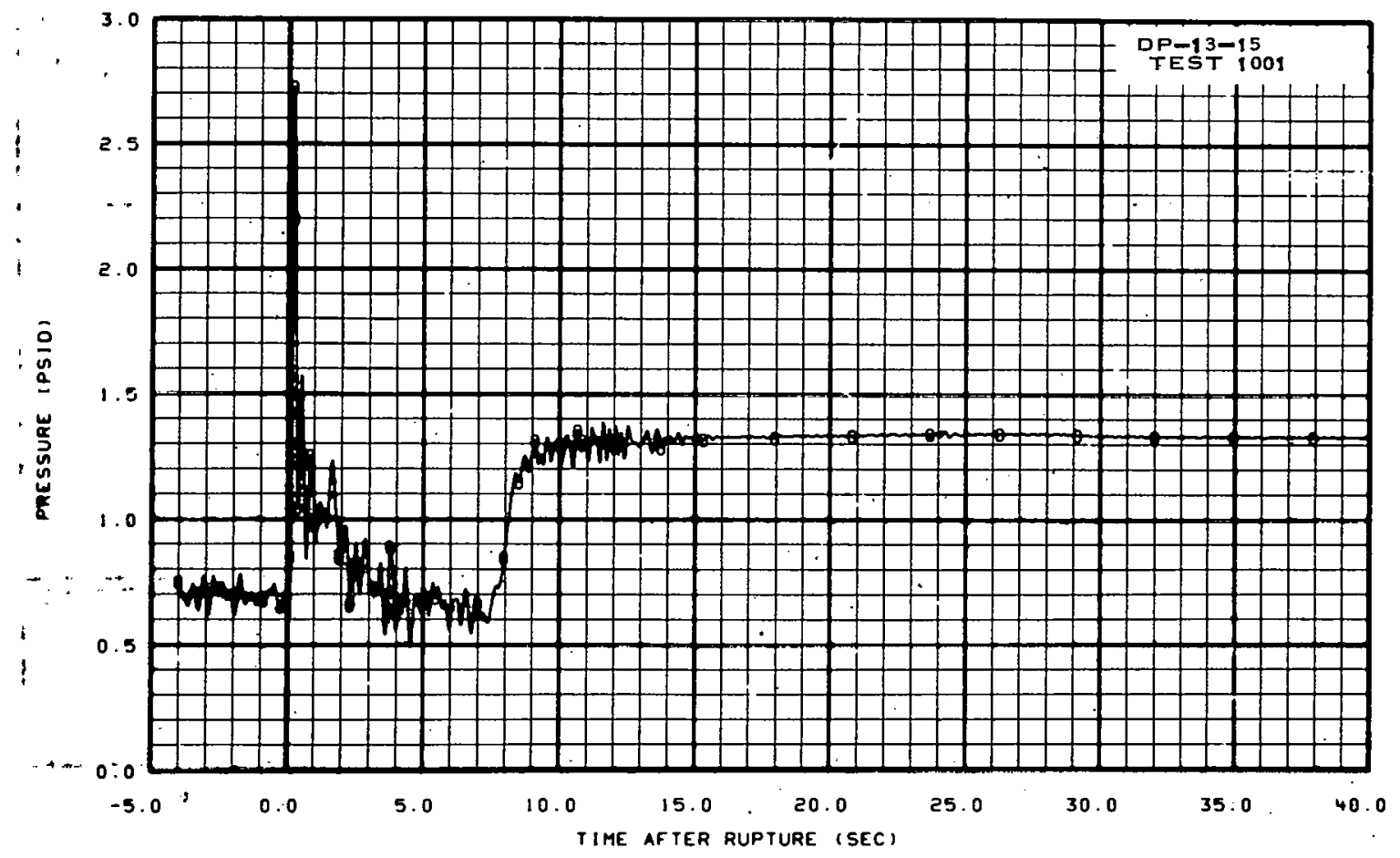

Fig. 128 Differential pressure across operating loop pump inlet (DP-13-15) -- Test 1001 . 


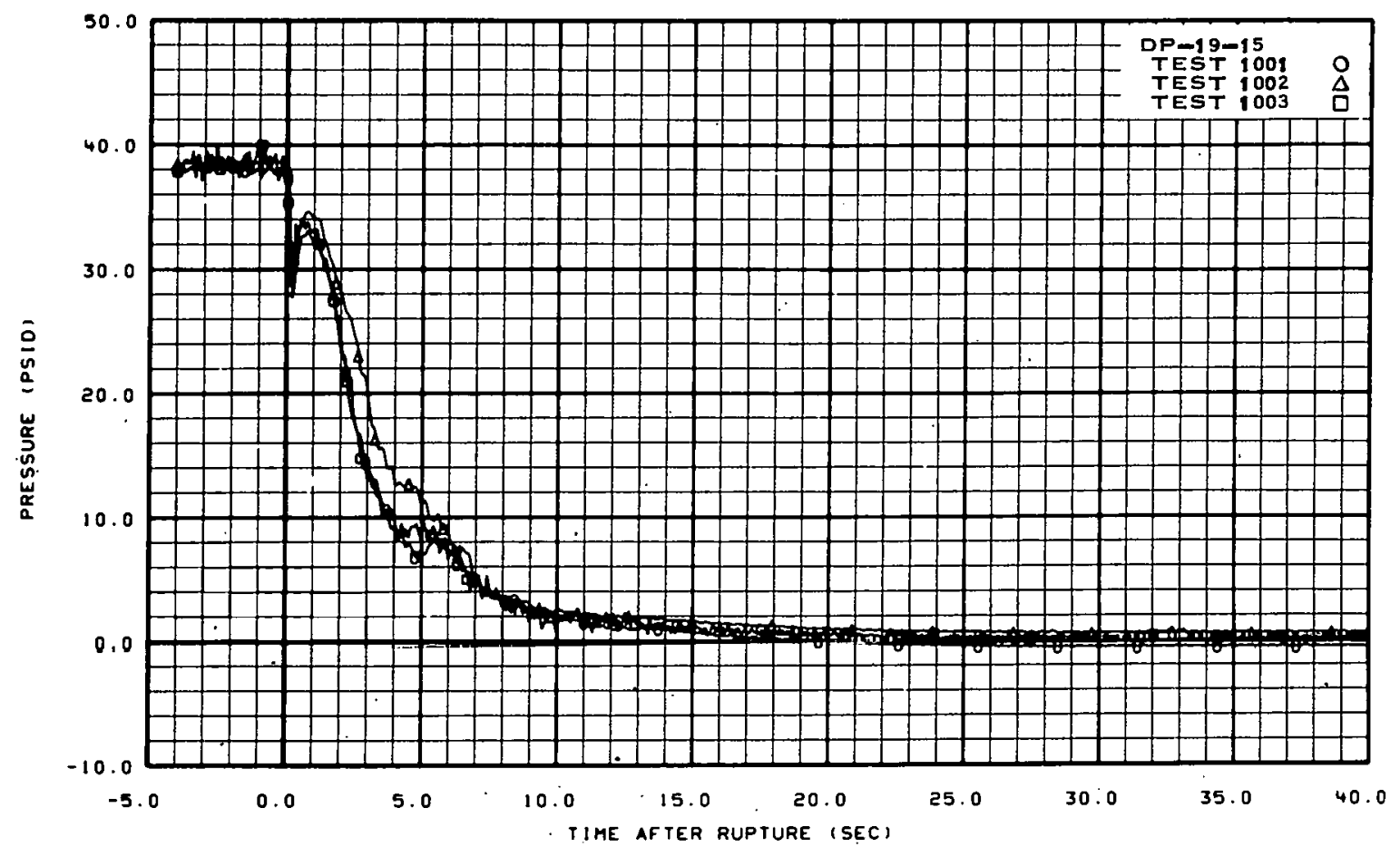

Fig. 129 Differential pressure across operating loop pump (DP-19-15) -Tests 1001, 1002, and 1003 .

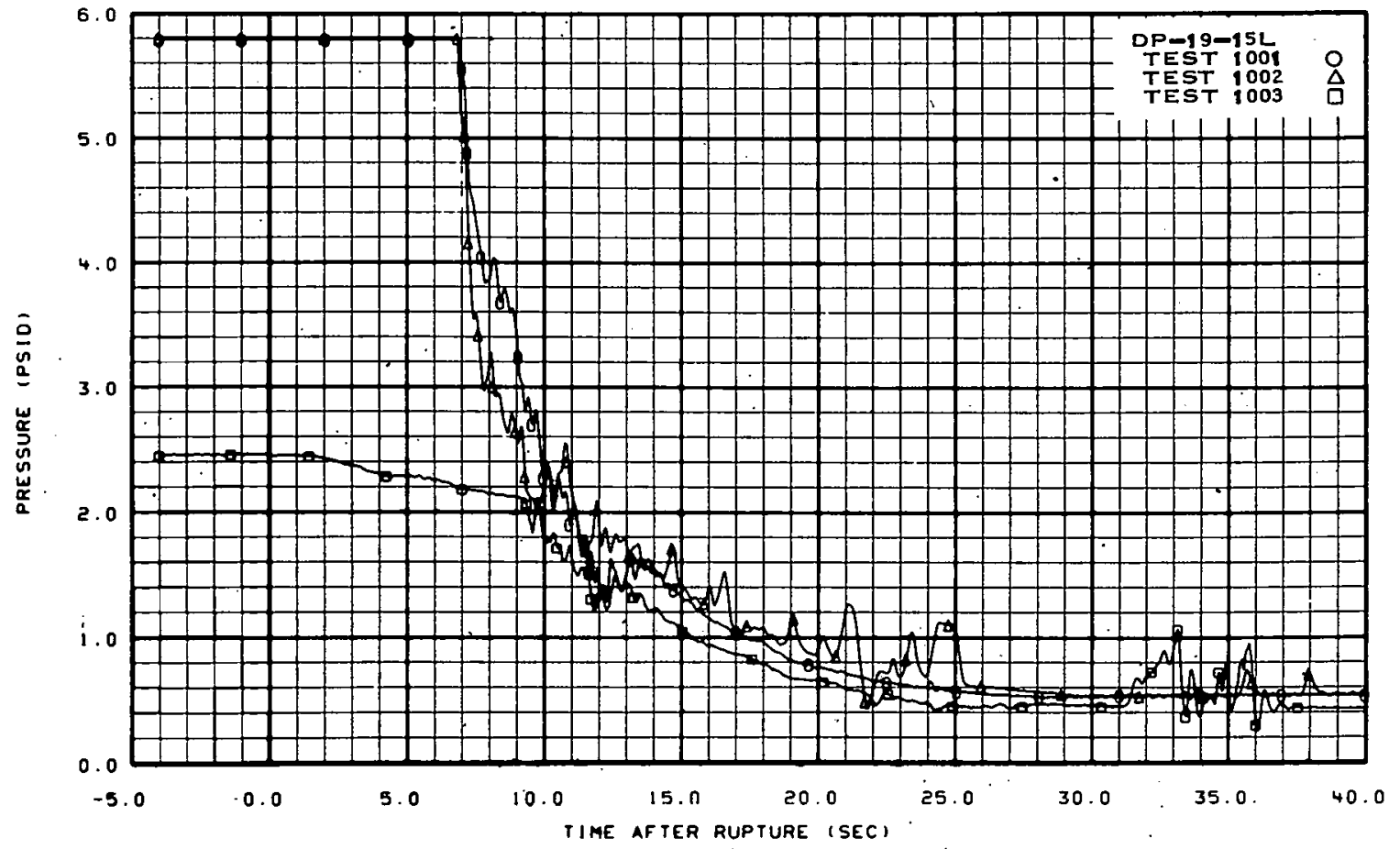

Fig. 130 Differential pressure across operating loop pump, low range (DP19-15L) -- Tests 1001, 1002, and 1003. 


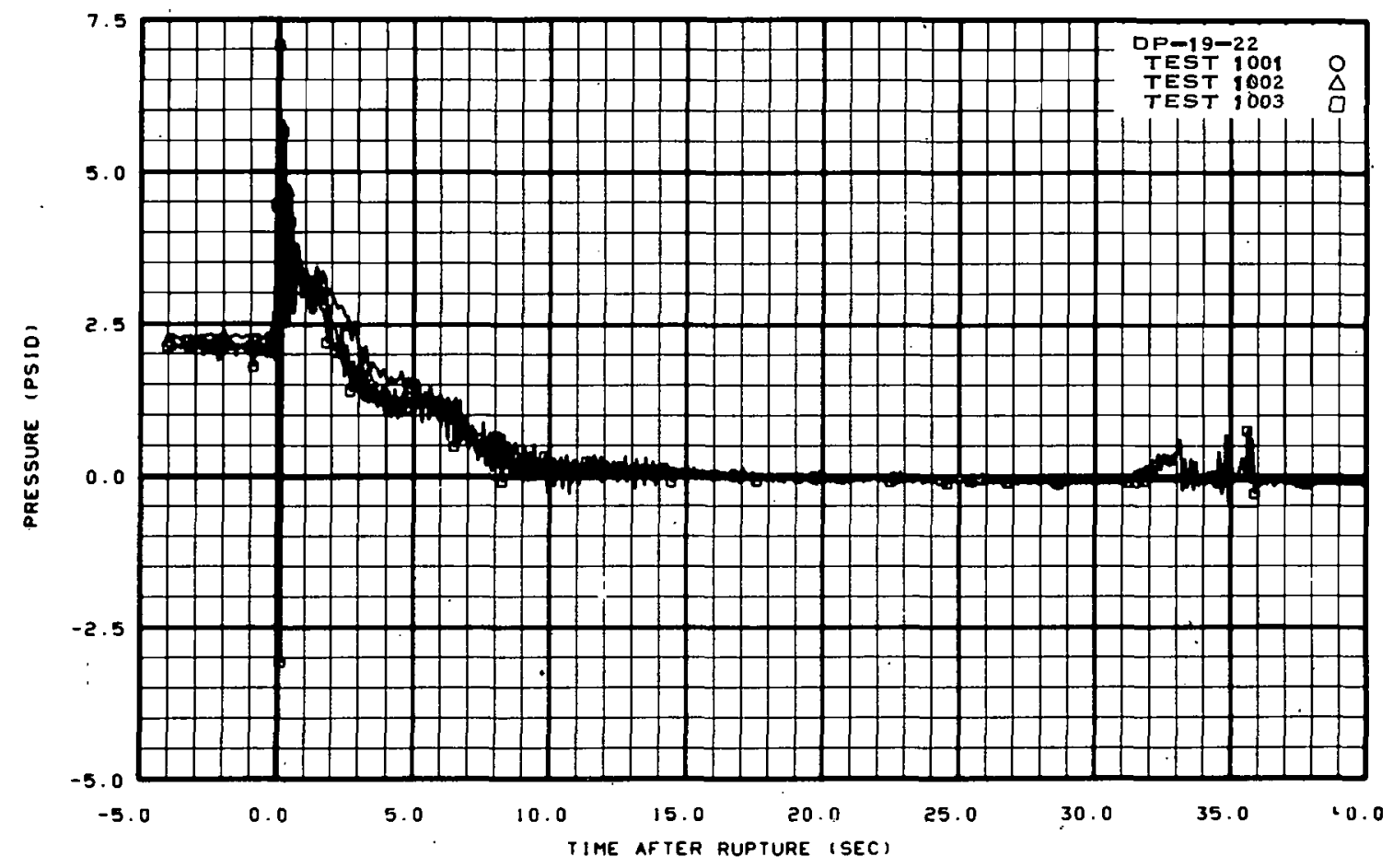

Fig. 131 Differential pressure across operating loop cold leg (DP-19-22) -Tests 1001, 1002, and 1003.

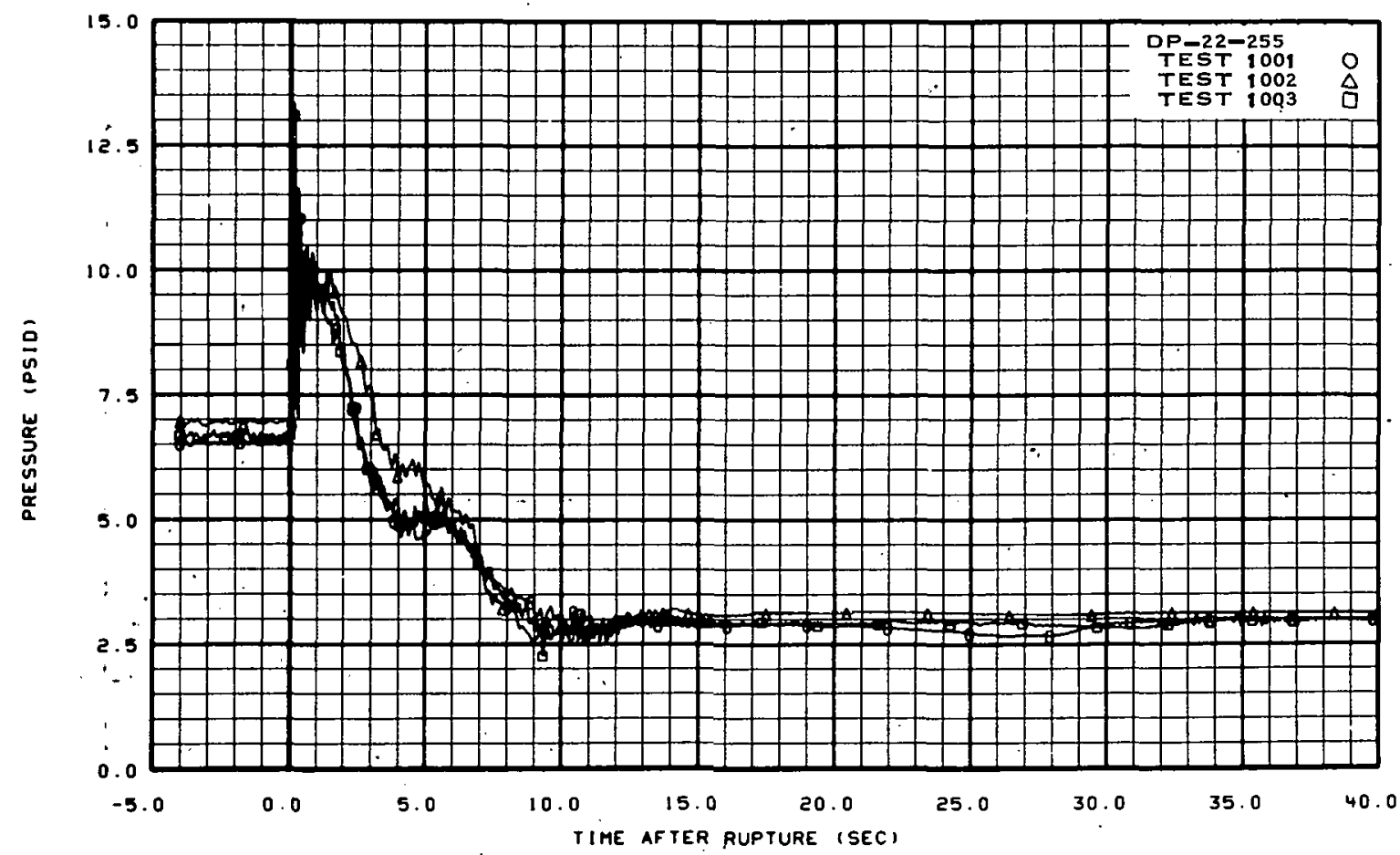

Fig: 132 Différèntial pressure between cold leg and lower plenum (DP-22255) -- Tests 1001, 1002, and 1003. 


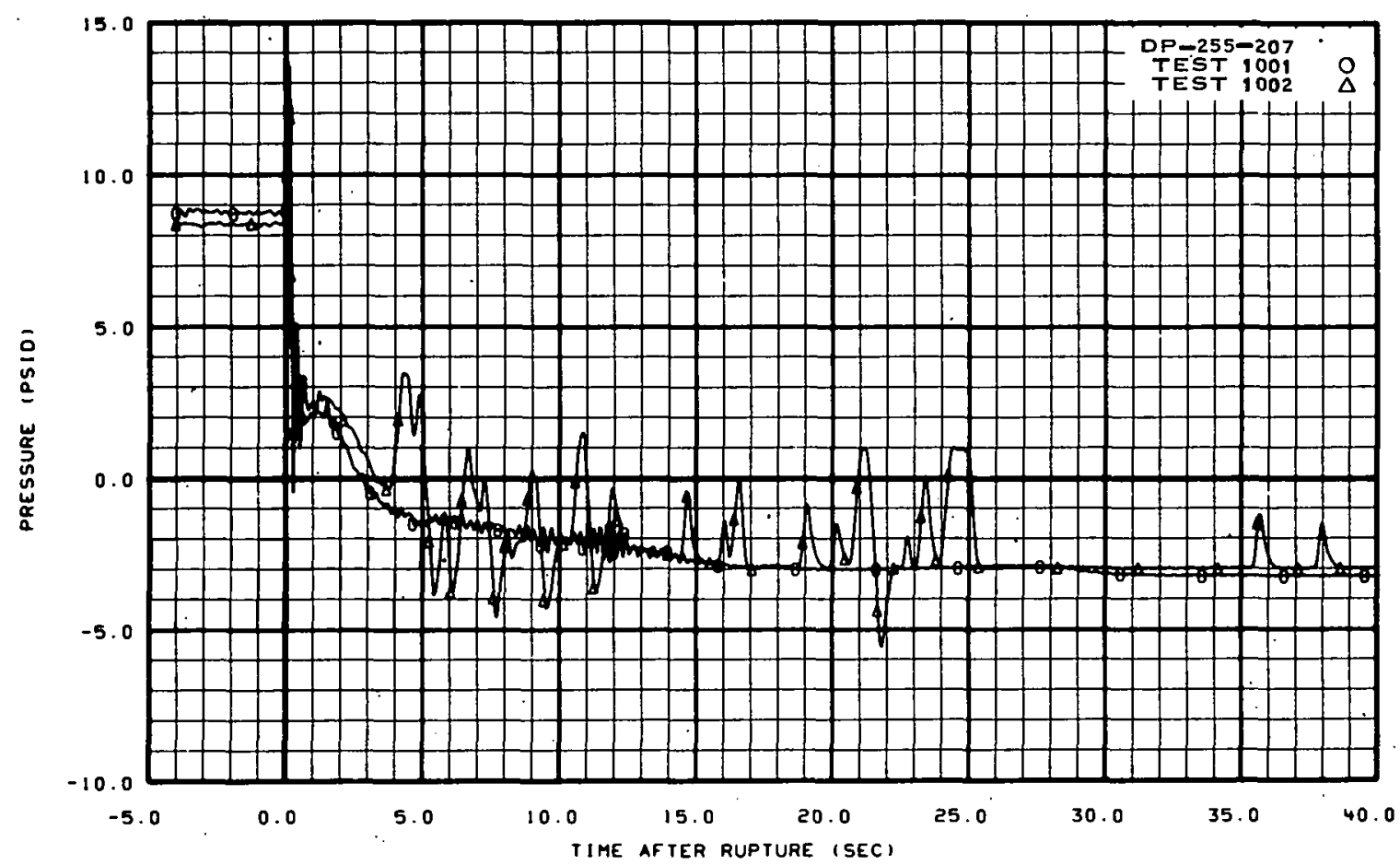

Fig. 133 Differential pressure across core (DP-255-207) -- Tests 1001 and 1002 .

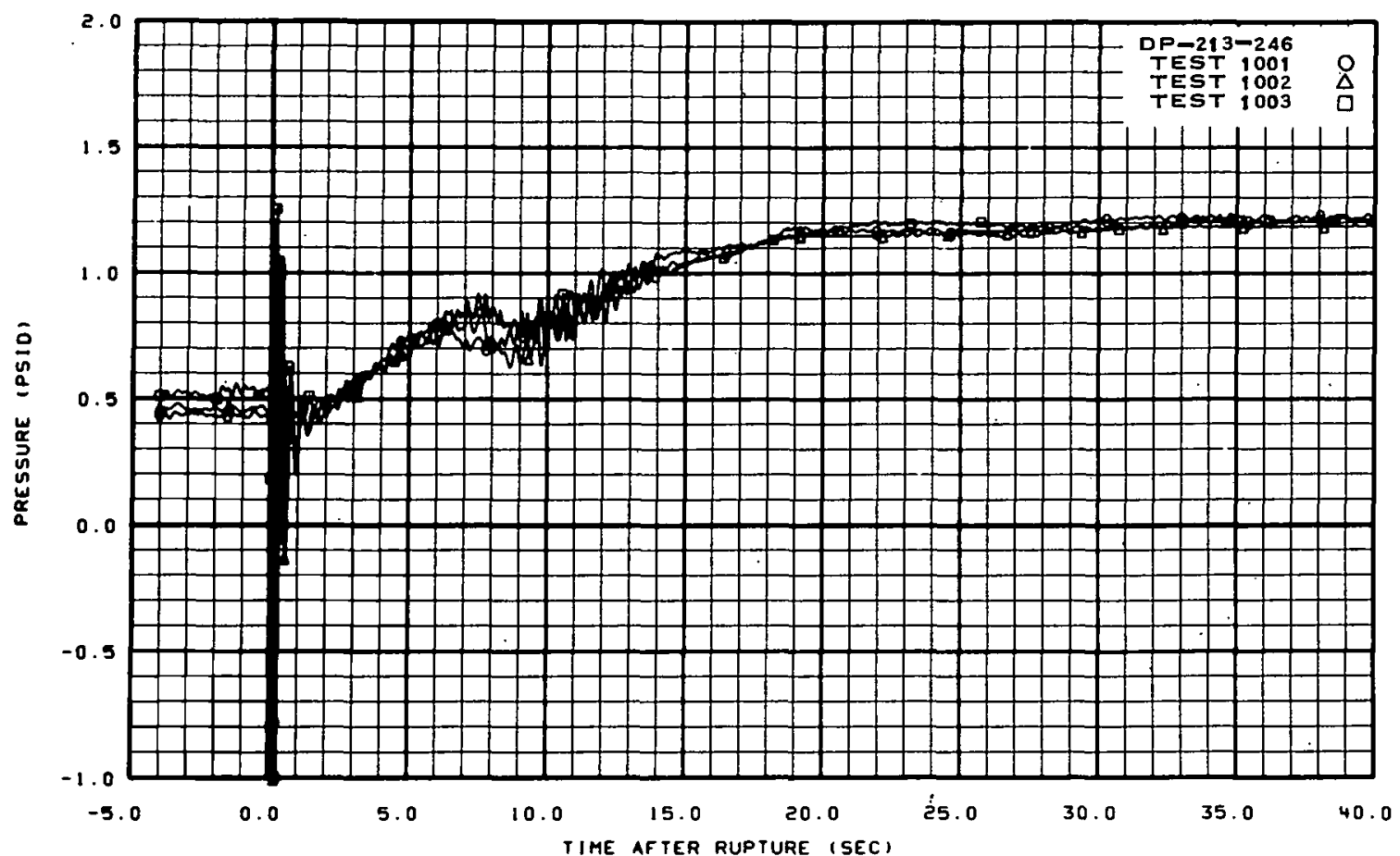

Fig. 134 Differential pressure across upper portion of downcomer (DP-213246) -- Tests 1001, 1002, and 1003. 


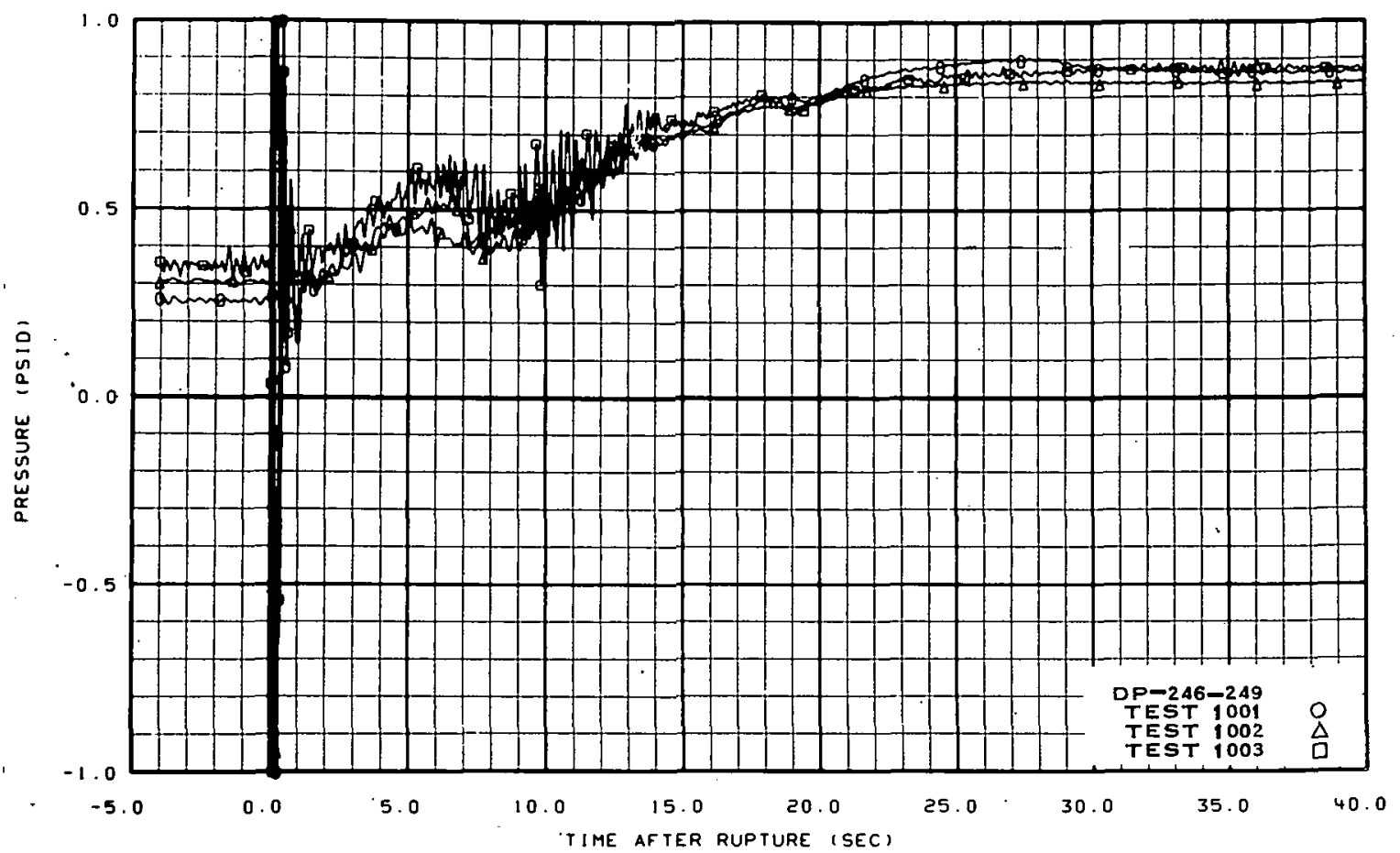

Fig. 135 Differential pressure across middle portion of downcomer (DP-246249) -- Tests 1001,1002 , and 1003.

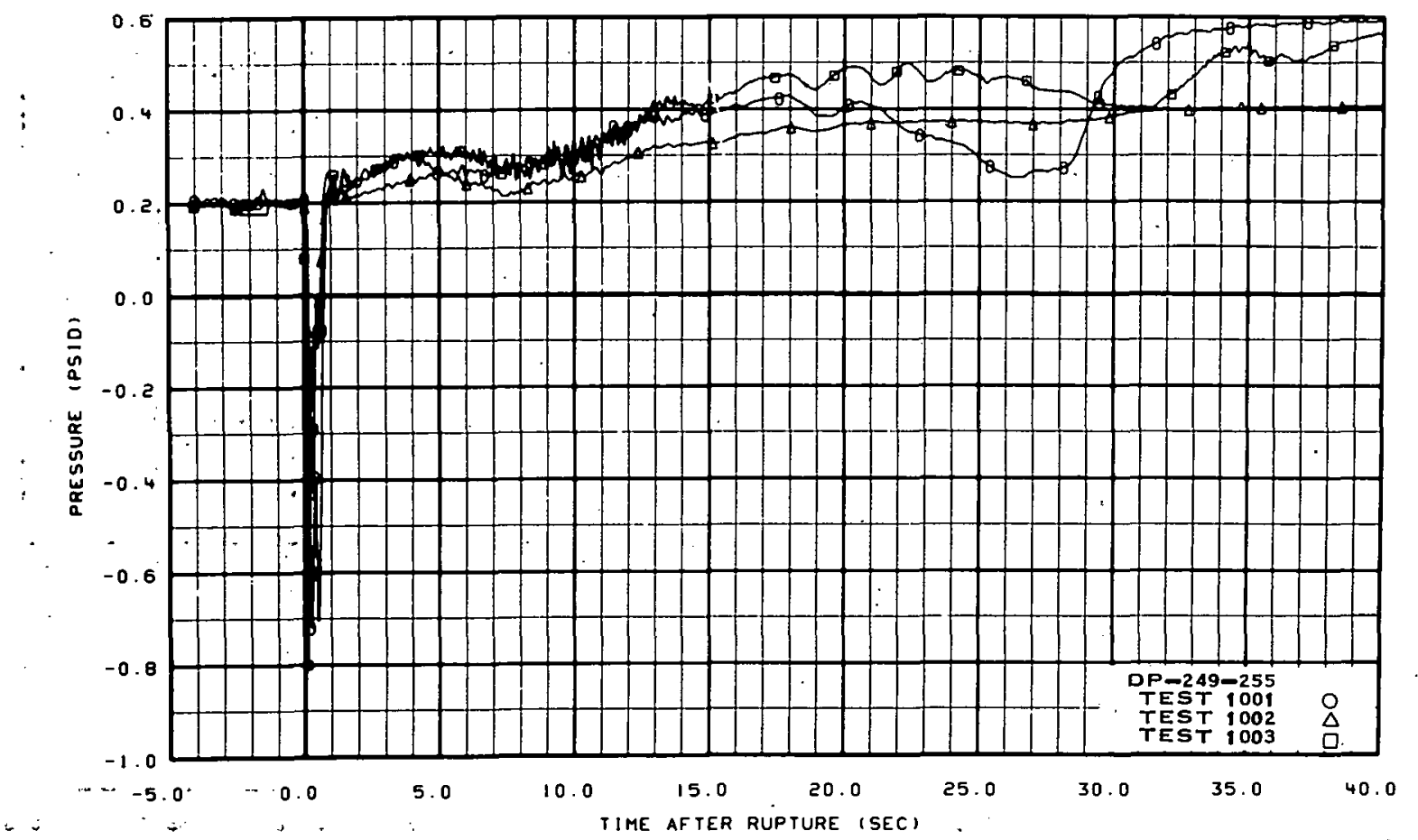

Fig. 136 Differential pressure across lower portion of downcomer (DP-249255) :- Tests 1001,1002 , and 1003. 


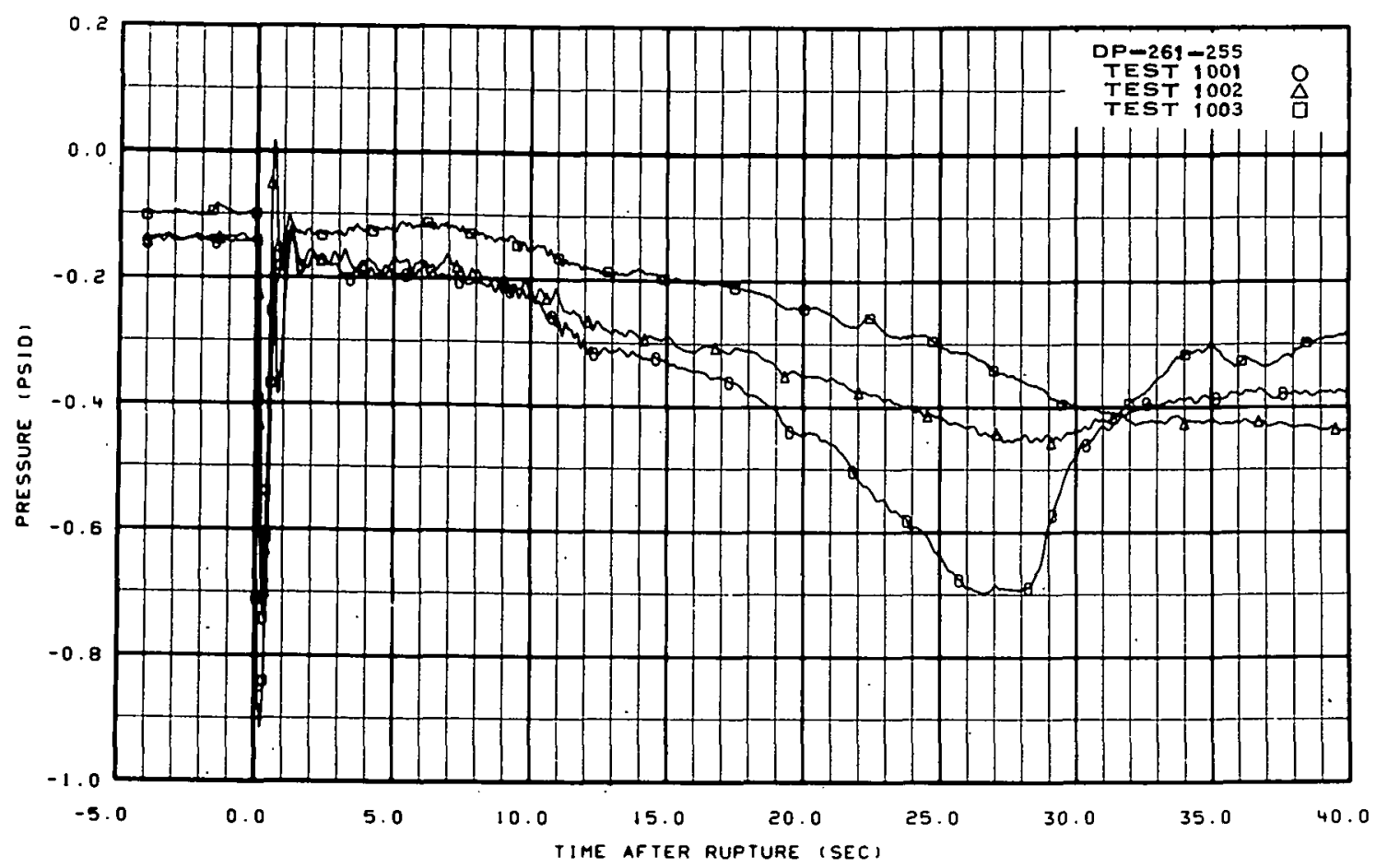

Fig. 137 Differenital pressure across lower plenum (DP-261-255) -- Tests 1001, 1002, and 1003.

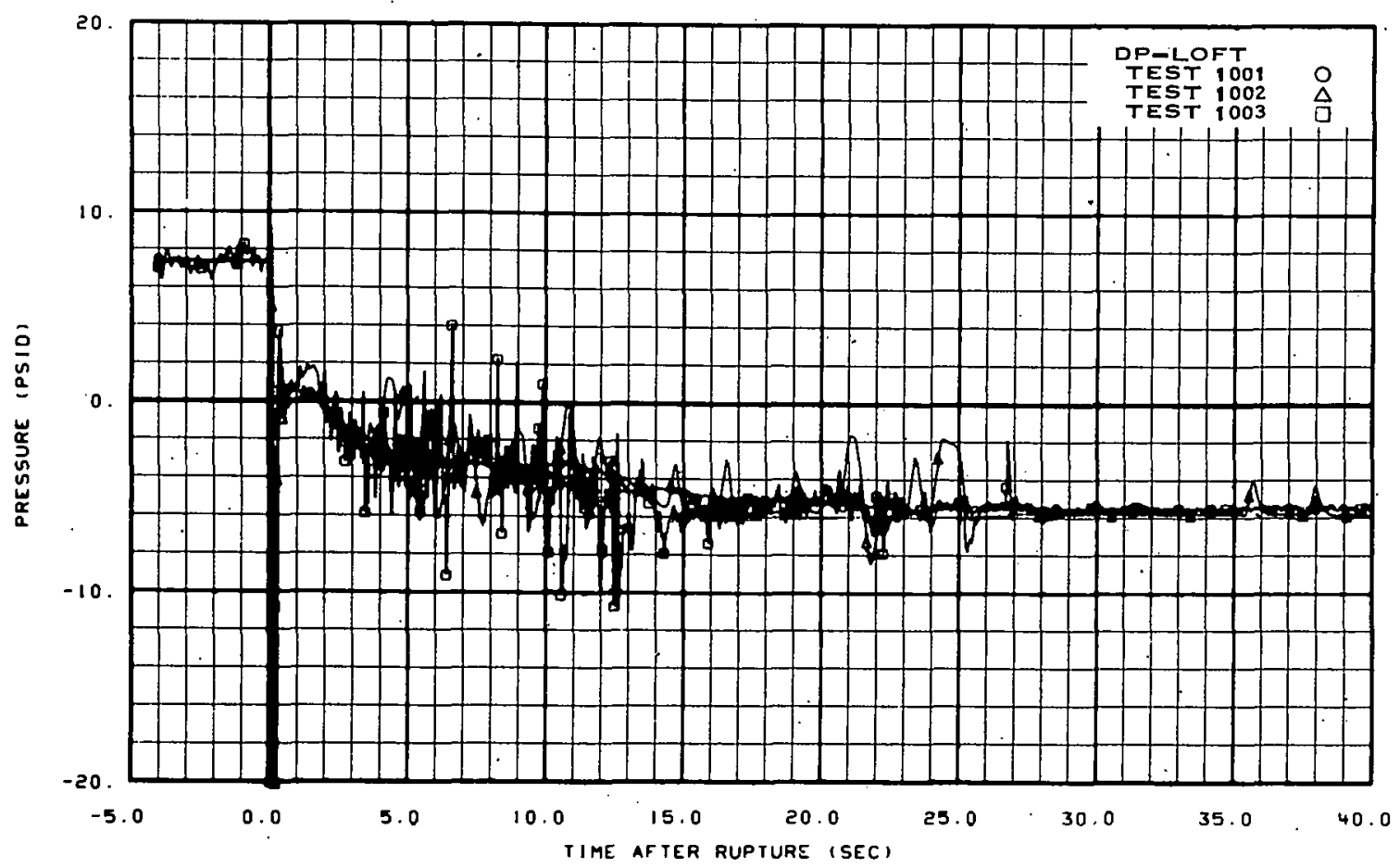

Fig. 138 Differential pressure across vessel (DP-LOFT) -- Tests 1001, 1002, and 1003 . 


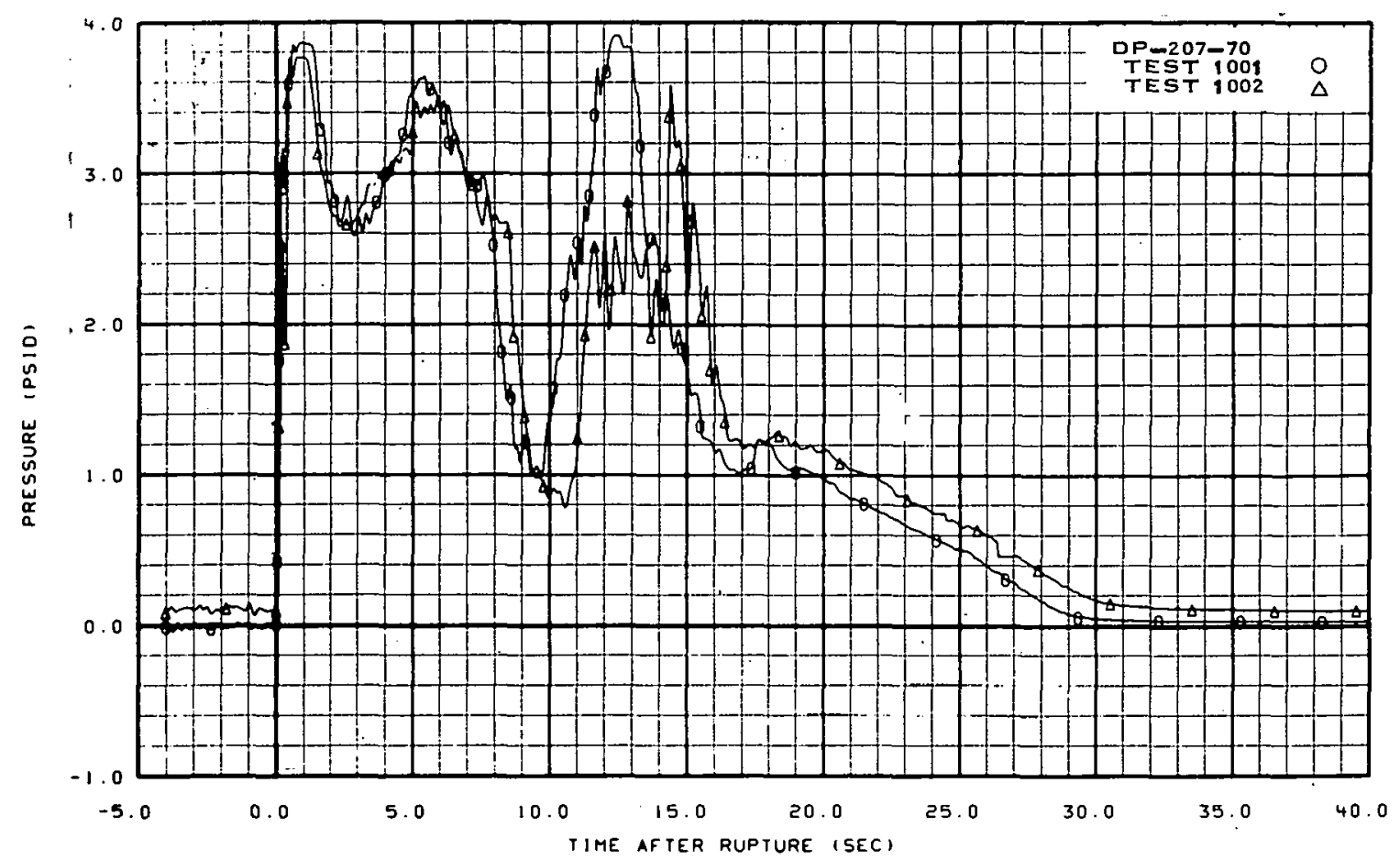

Fig. 139 Differential pressure between vessel upper plenum and blowdown loop hot leg (DP-207-70) -- Tests 1001 and 1002.

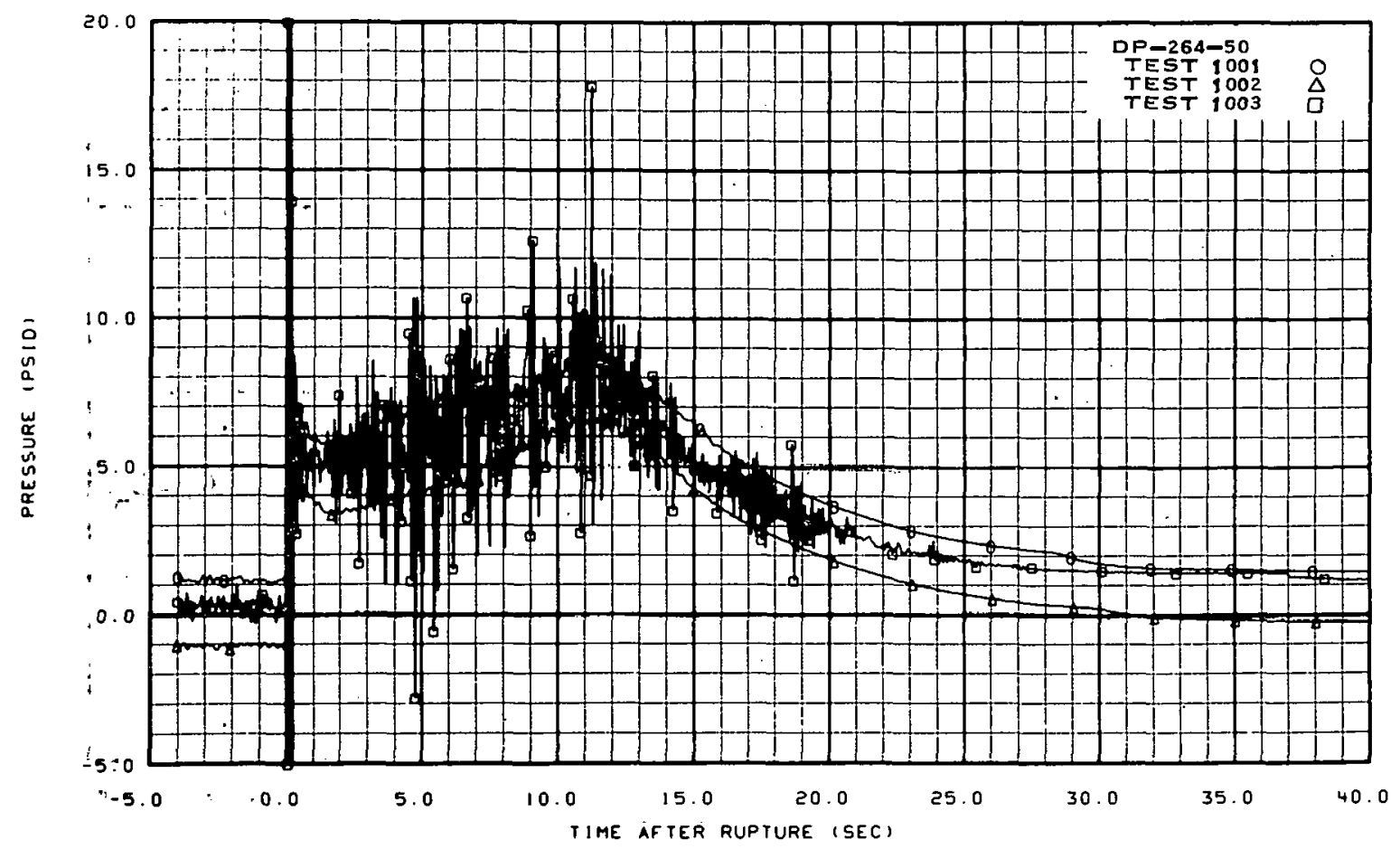

Fig.' 140 'Diffèrential pressure between vessel inlet annulu's and blowdown' $\cdots$ loop cold leg (DP-264-50) -- Tests 1001, 1002, and 1003. 


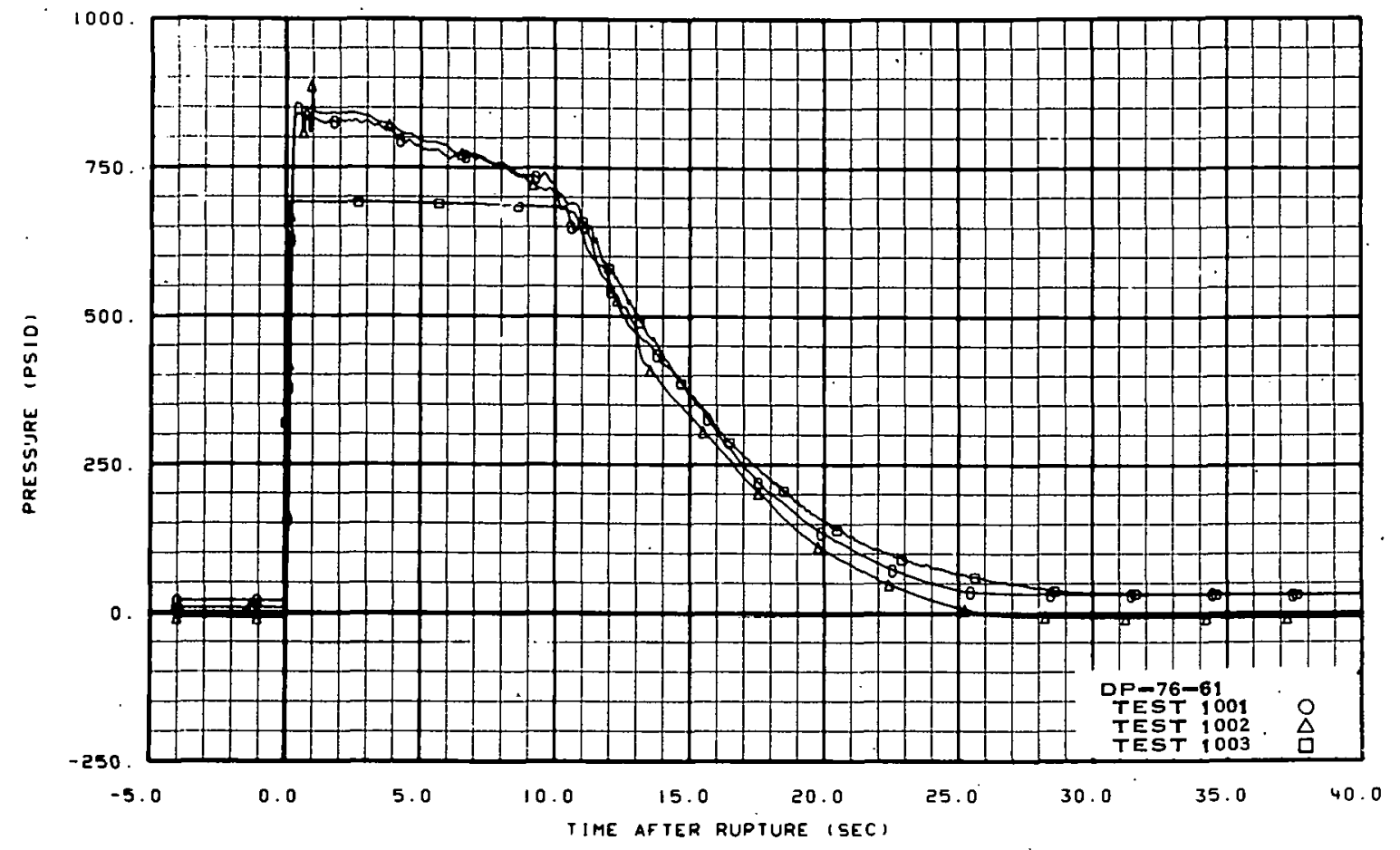

Fig. 141 Differential pressure across blowdown loop hot leg nozzle (DP-7661) -- Tests 1001, 1002, and 1003.

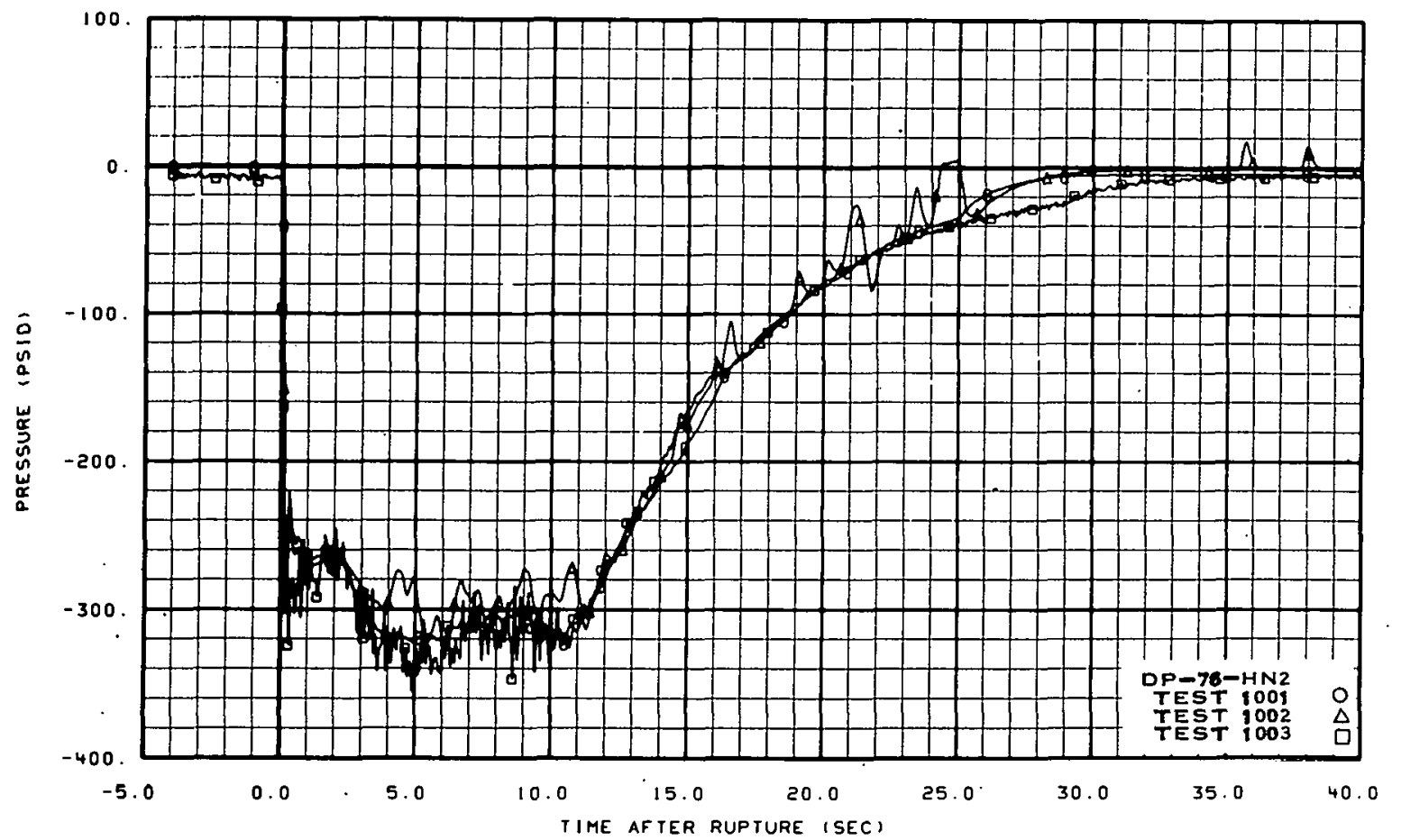

Fig. 142 Differential pressure between simulated pump and throat of blowdown loop hot leg nozale (DP-76-HN2) -- Tests 1001, 1002, and 1003. 


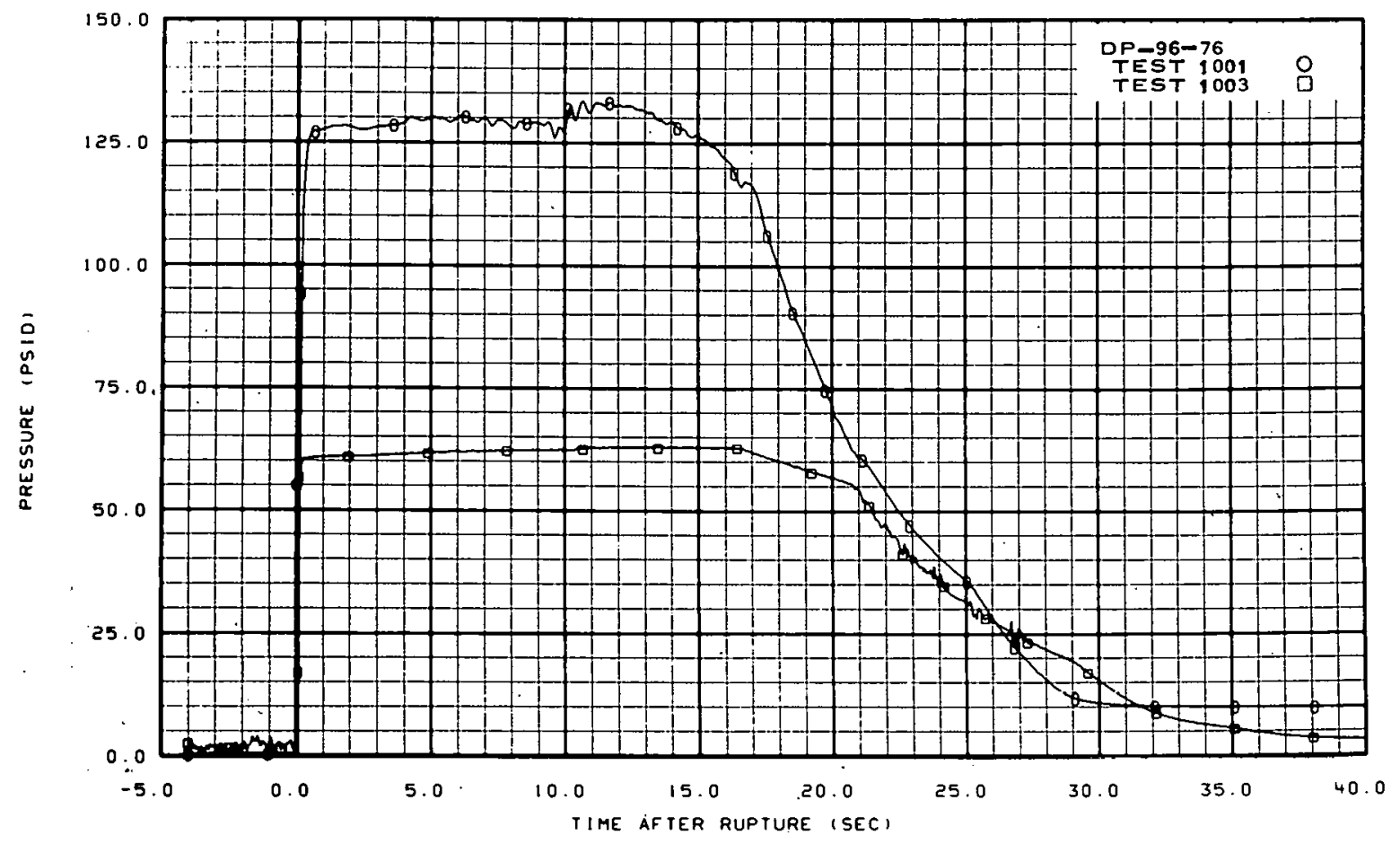

Fig. 143 Differential pressure across simulated pump (DP-96-76) -- Tests 1001 and 1003 .

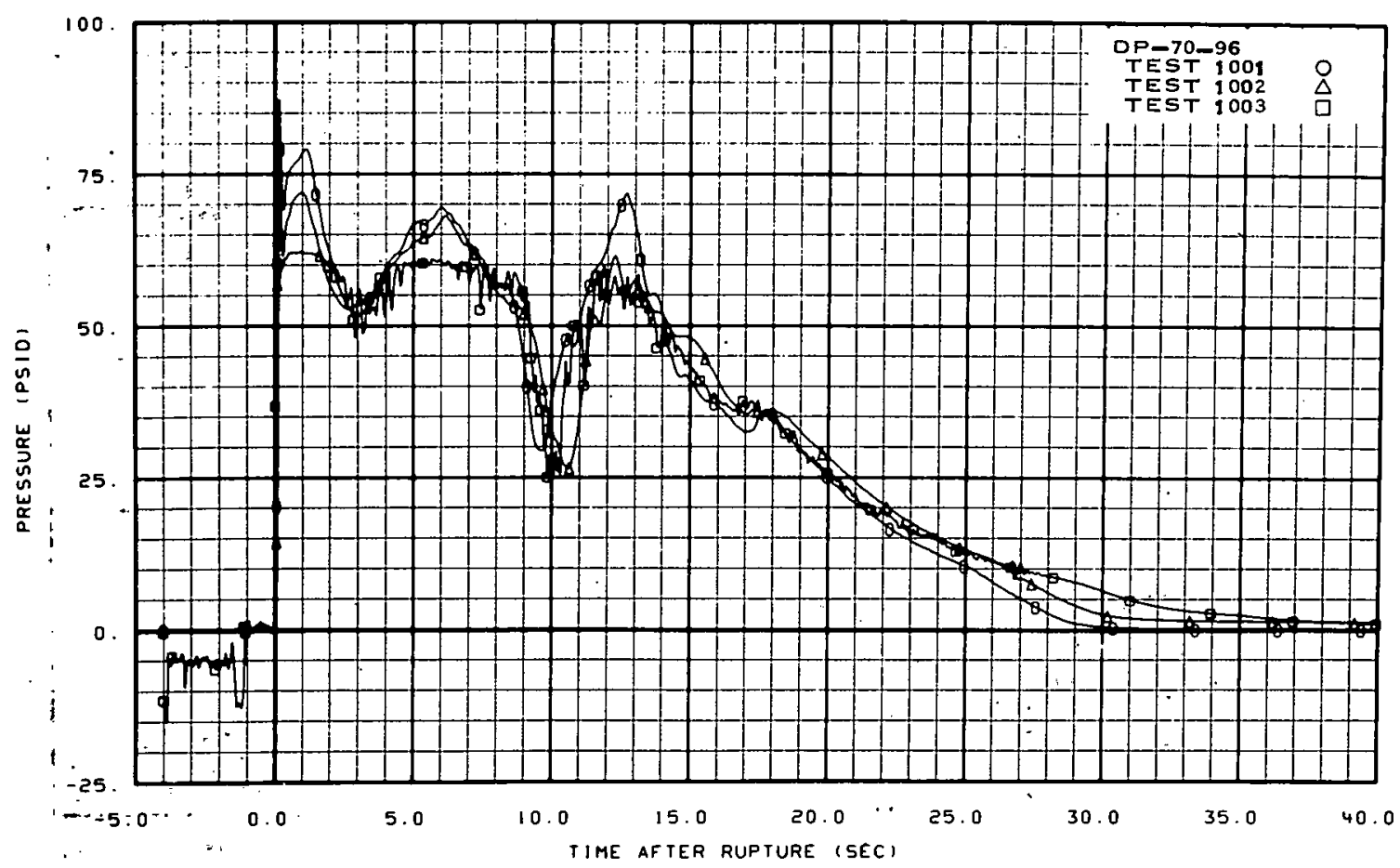

Fig. 144 Differential pressure across simulated steam generator (DP-70-96) -Tests:1001,:1002, and 1003. 


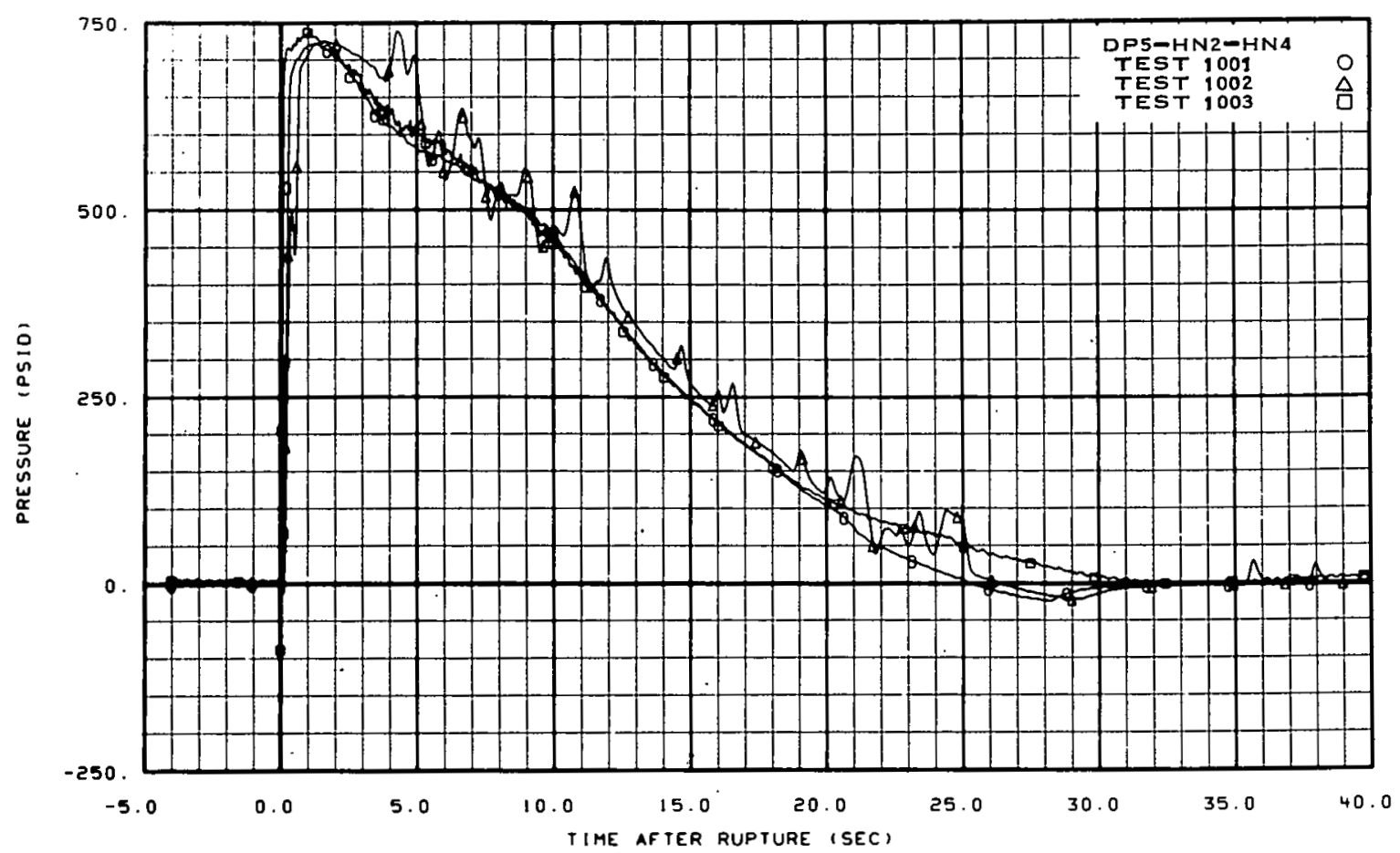

Fig. 145 Differential pressure across blowdown loop cold leg nozzle diverging section (DP5-HN2-HN4) -- Tests 1001, 1002, and 1003.

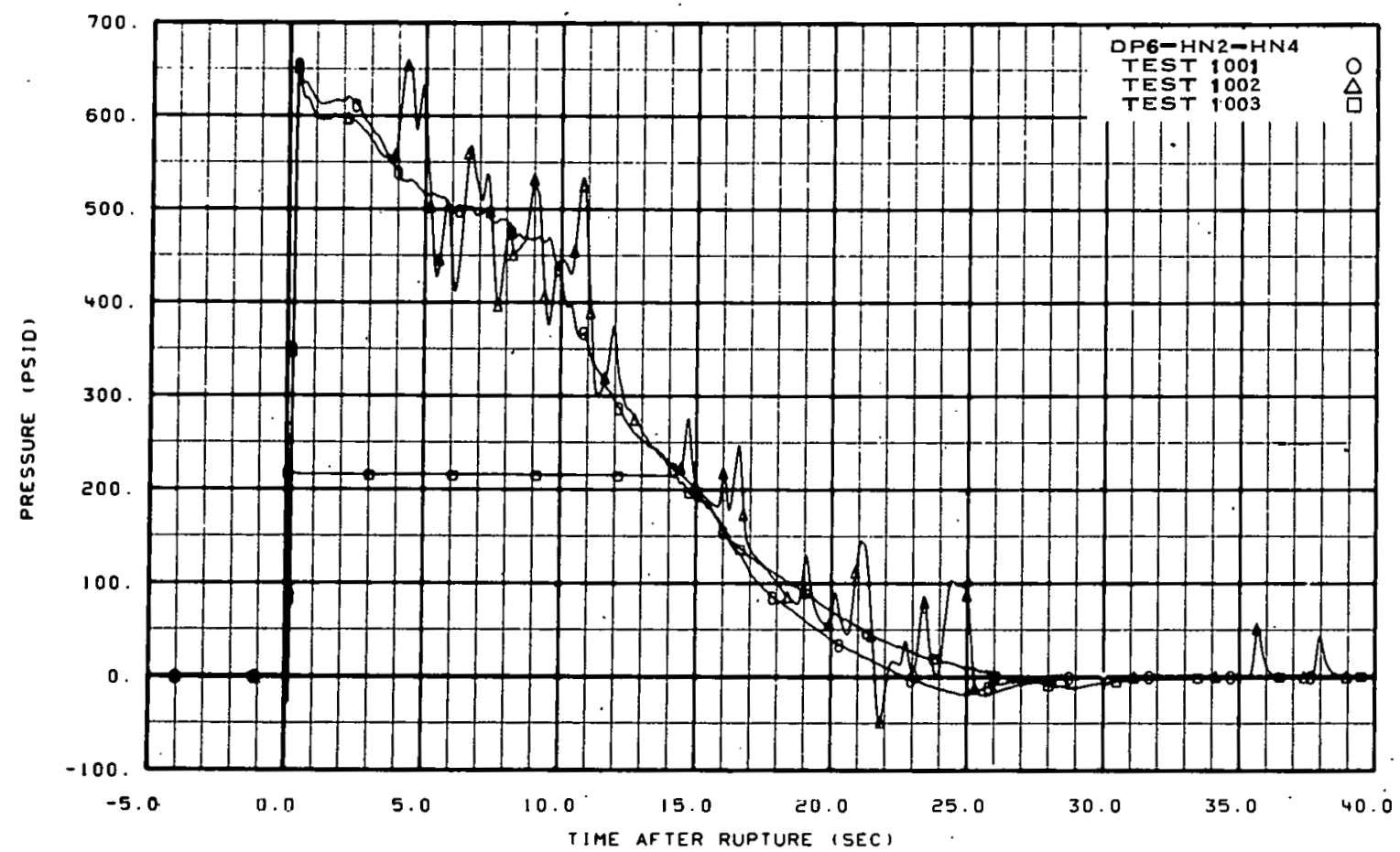

Fig. 146 Differential pressure across blowdown loop hot leg nozzle diverging section (DP6-HN2-HN4) -- Tests 1001, 1002, and 1003. 


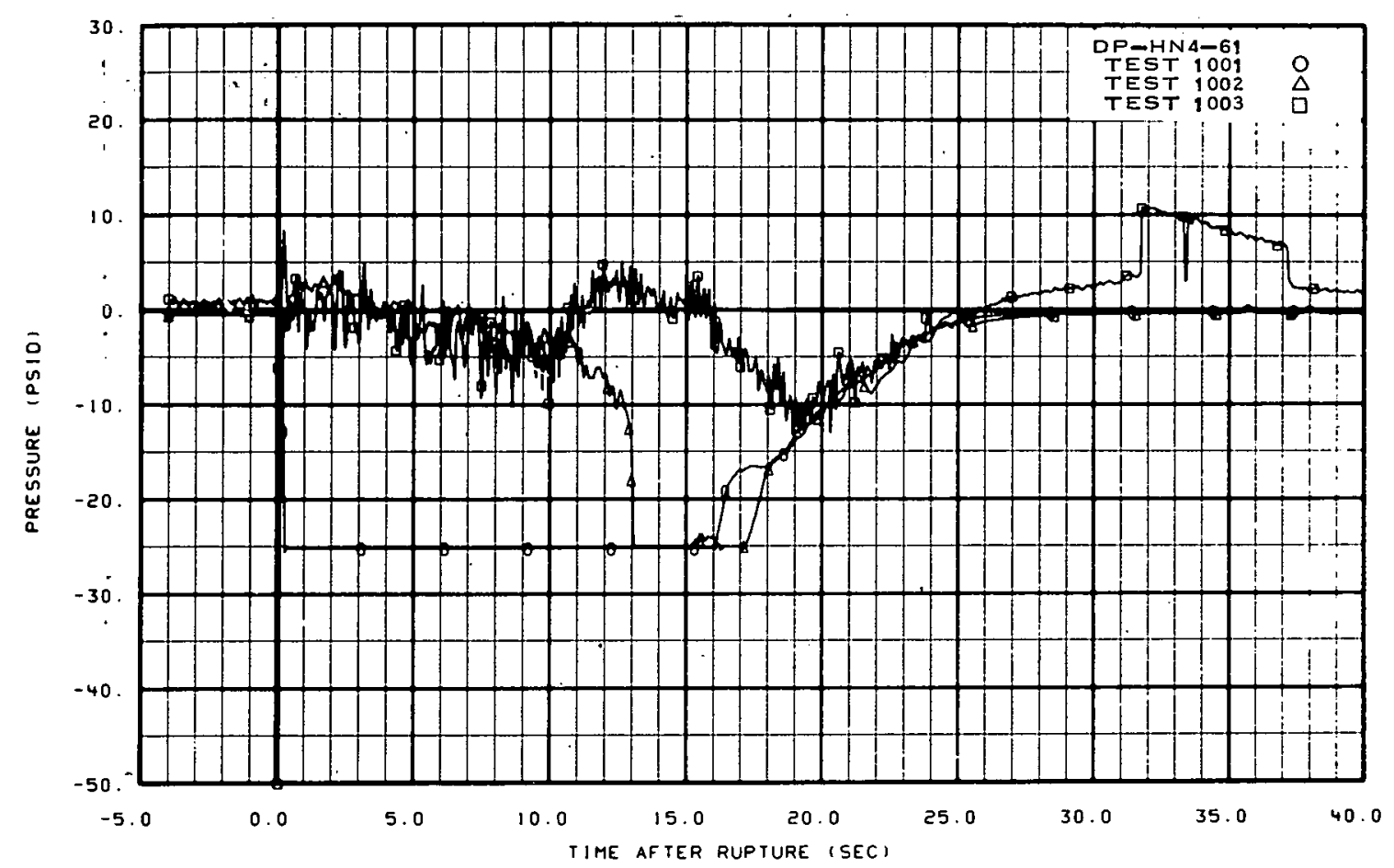

Fig. 147 Differential pressure across blowdown loop hot leg nozzle, Station 61 (DP-HN4-61) -- Tests 1001, 1002, and 1003.

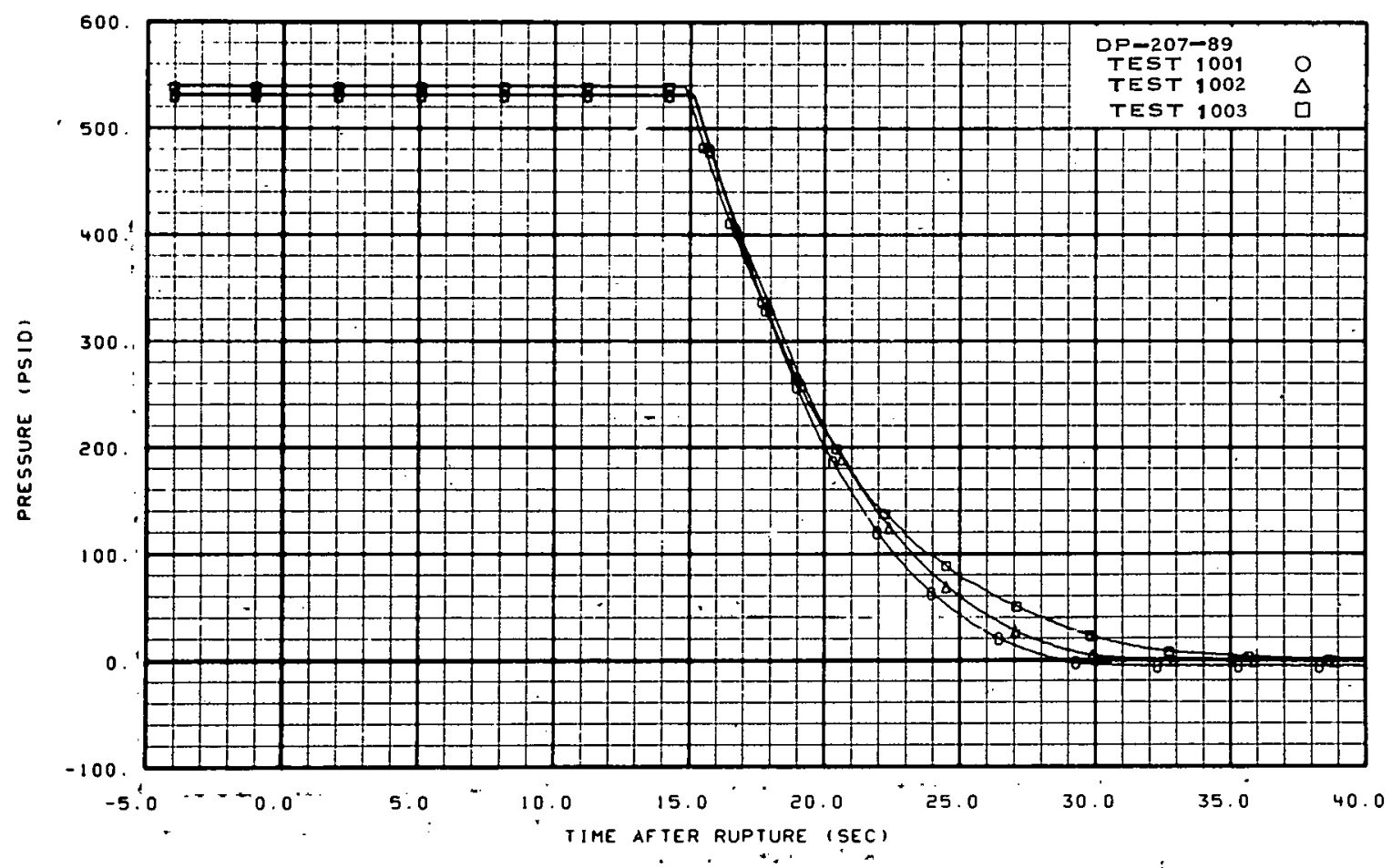

Fig. 148 Differential pressure between vessel upper plenum and pressure . . . . : suppression tank vapor chamber.(DP-207-89) -- Tests :1001, 1002, and 1003. : . 


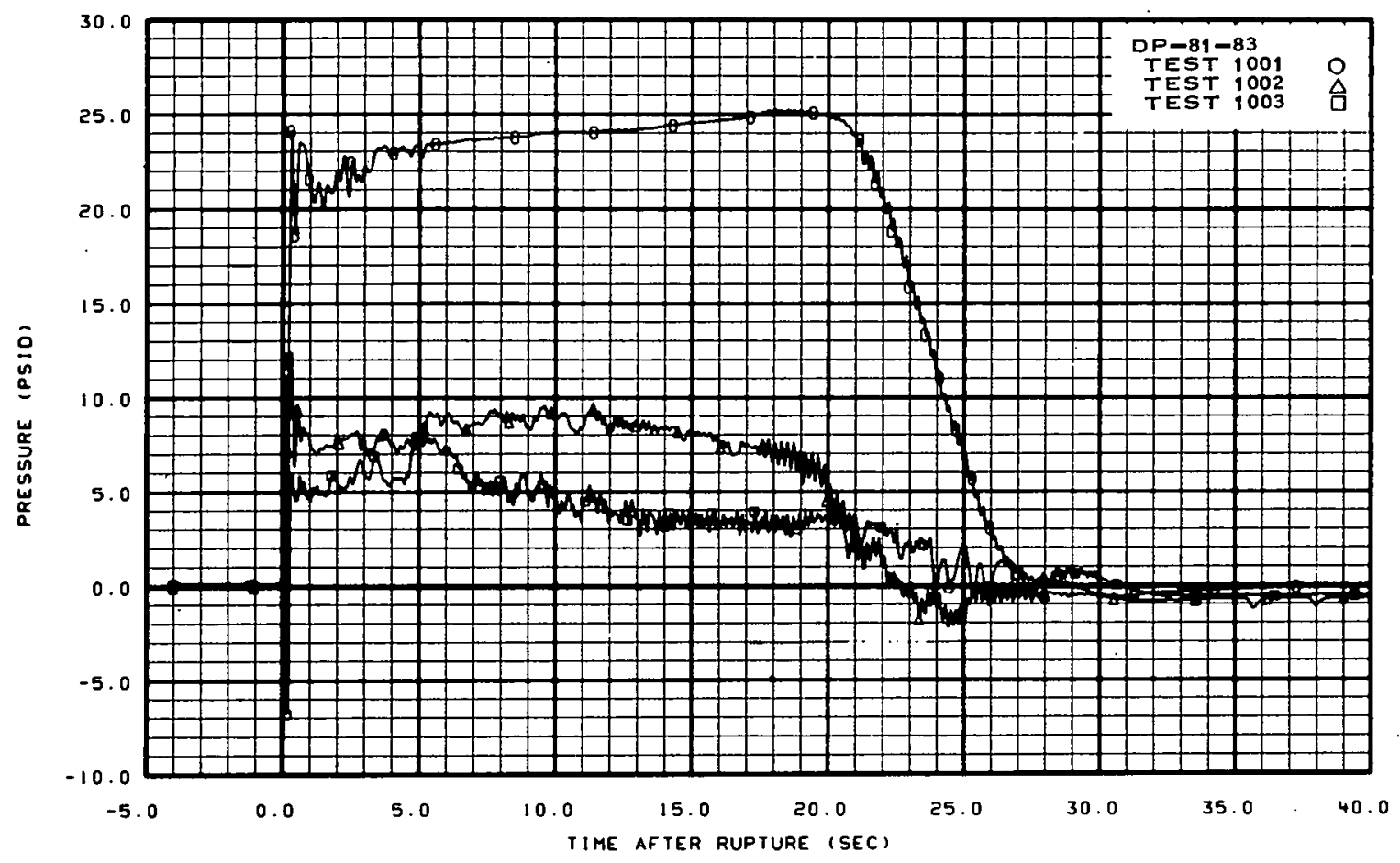

Fig. 149 Differential pressure between pressure suppression header and pressure suppression tank vapor chamber (DP-81-89) -- Tests 1001, 1002, and 1003.

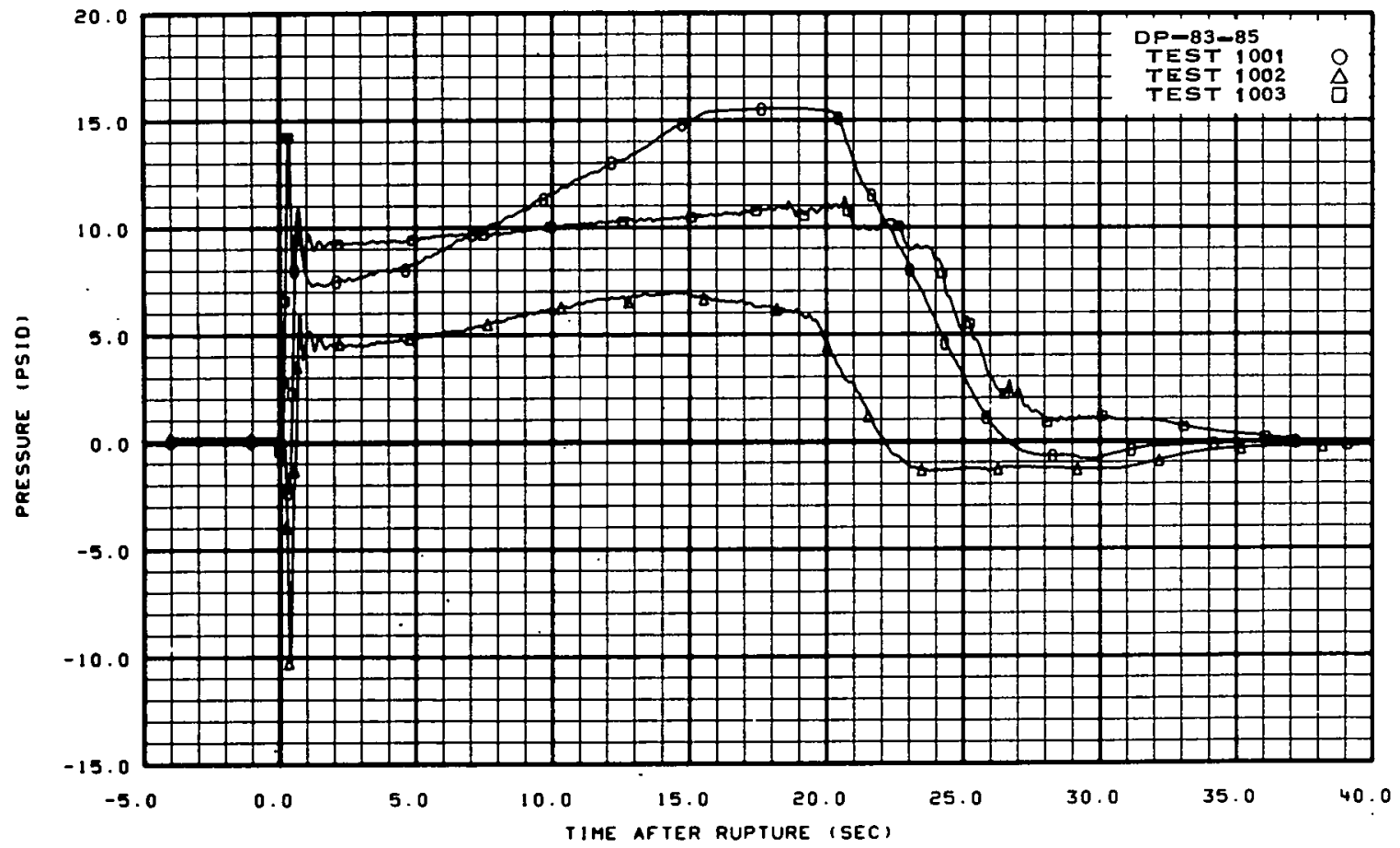

Fig. 150 Differential pressure between pressure suppression tank downcomer entranse and exit (DP-83-85) -- Tests 1001, 1002, and 1003. 


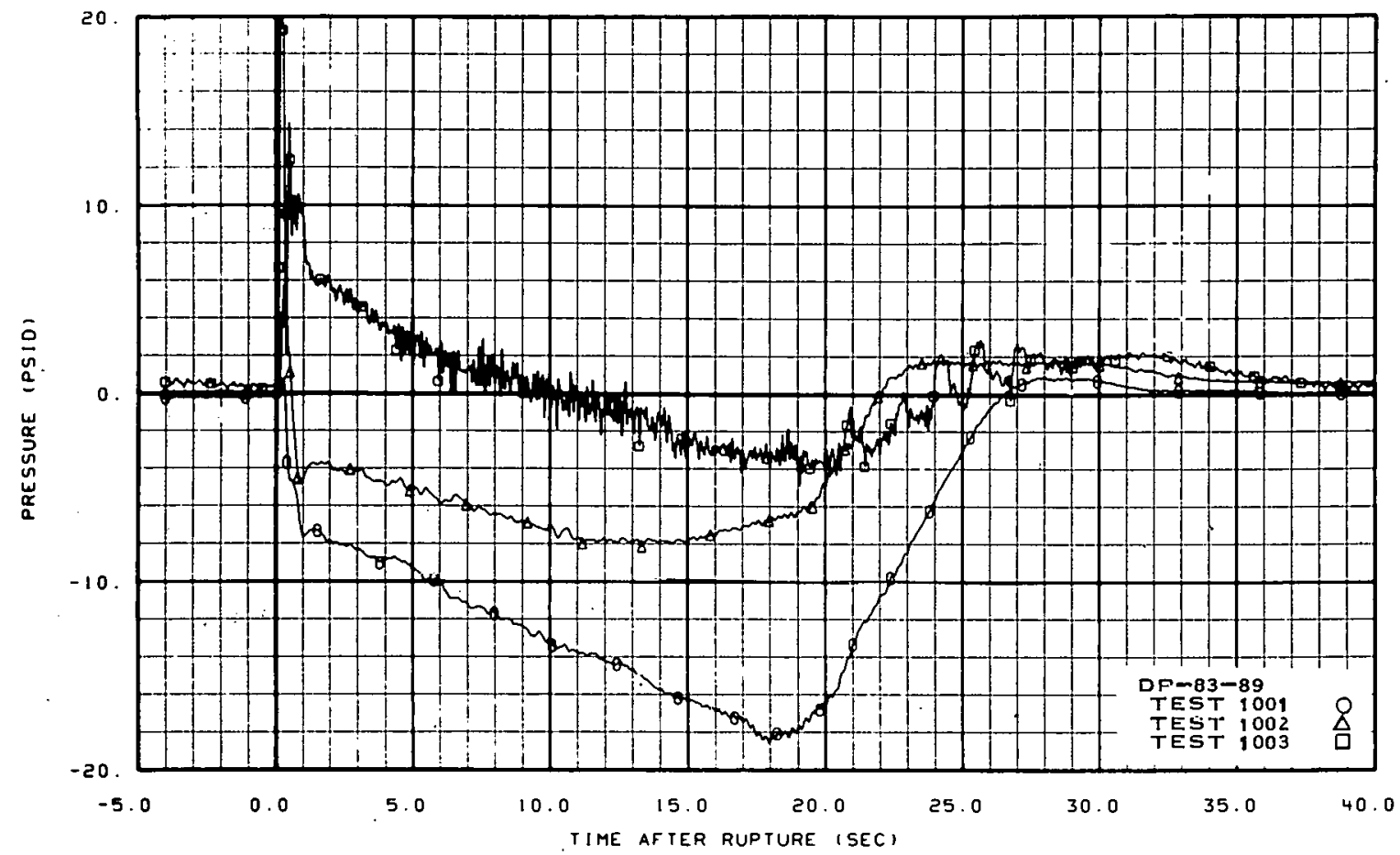

Fig. 151 Differential pressure between pressure suppression tank downcomer entrance and pressure suppression tank vapor chamber (DP-83-89) -- Tests 1001,1002 , and 1003.

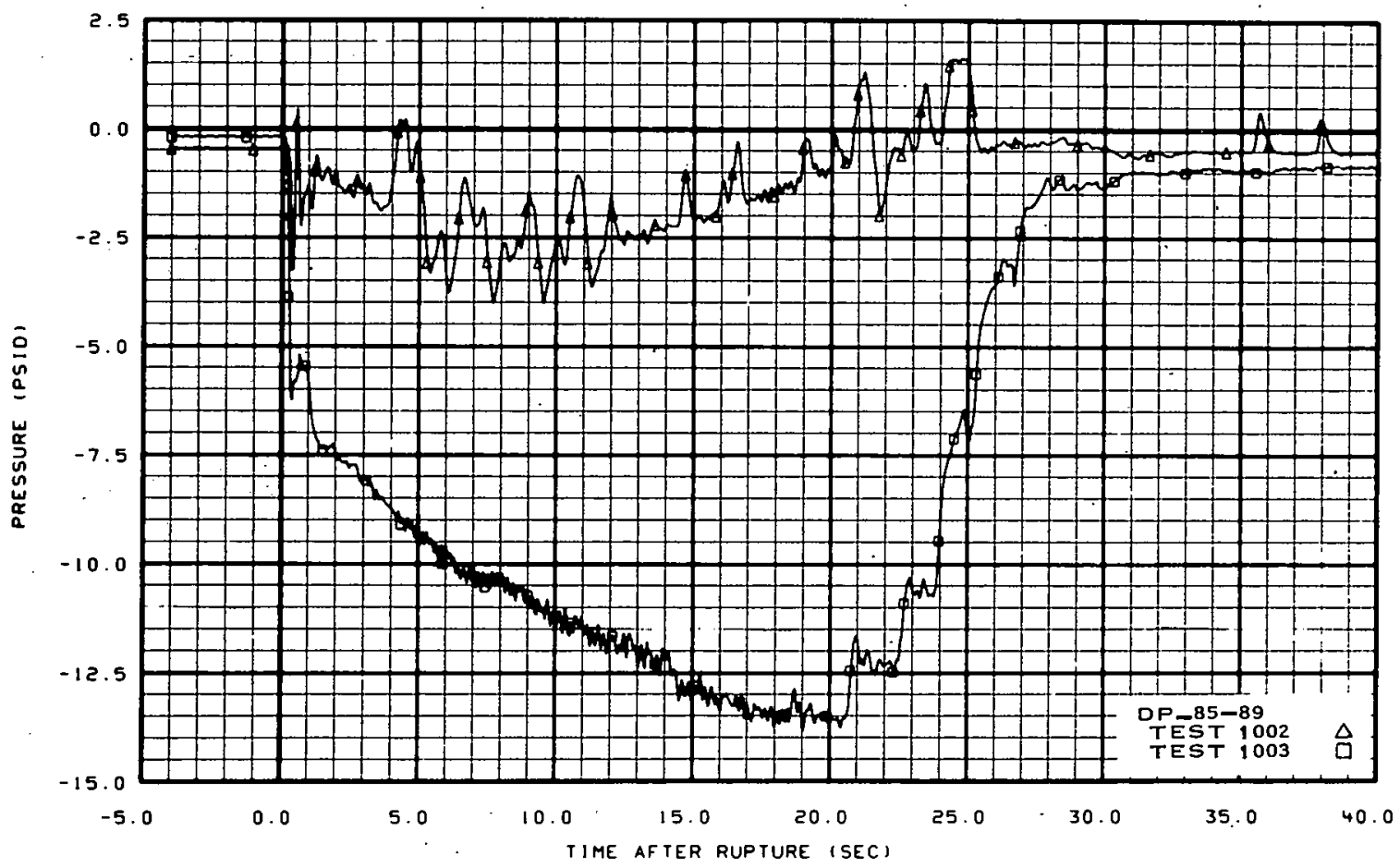

Fig. 152 Differential pressure between pressure suppression tank downcomer exit and pressure suppression tank vapor chamber (DP-85-89) -- Tests 1001, 1002 , and 1003. 


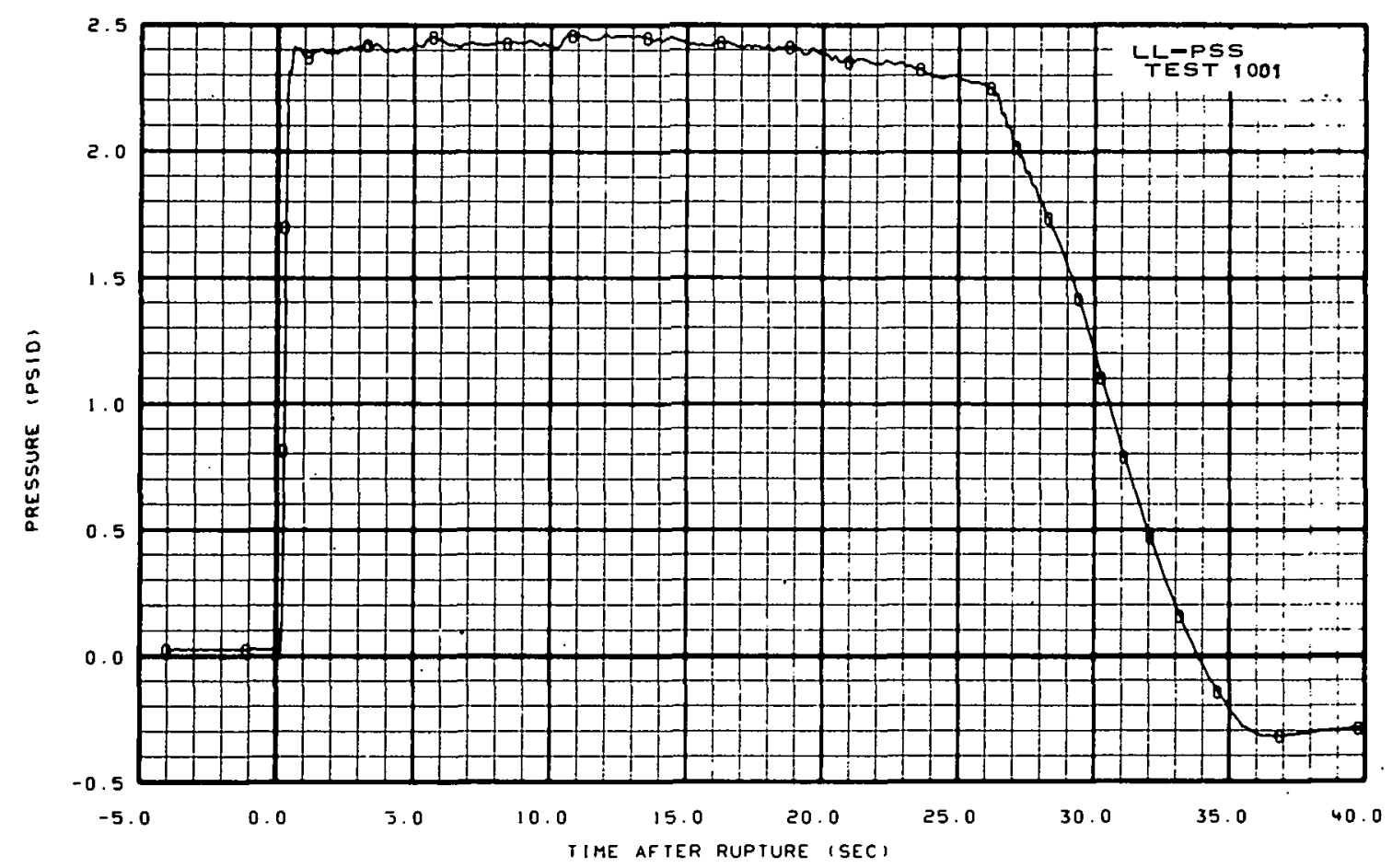

Fig. 153 Liquid level in pressure suppression tank -- Test 1001.

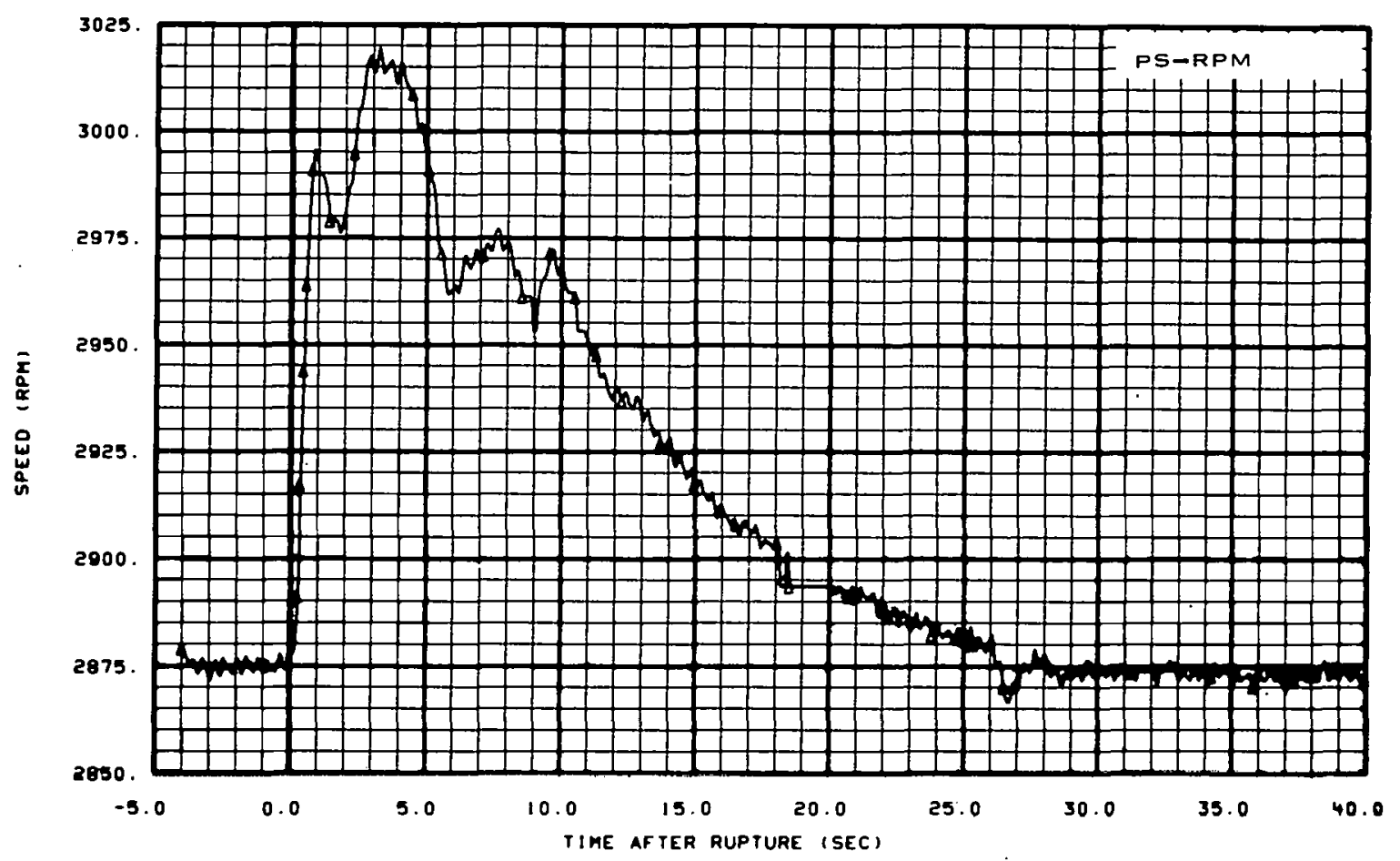

Fig. 154 Pump speed -- Test 1001. 


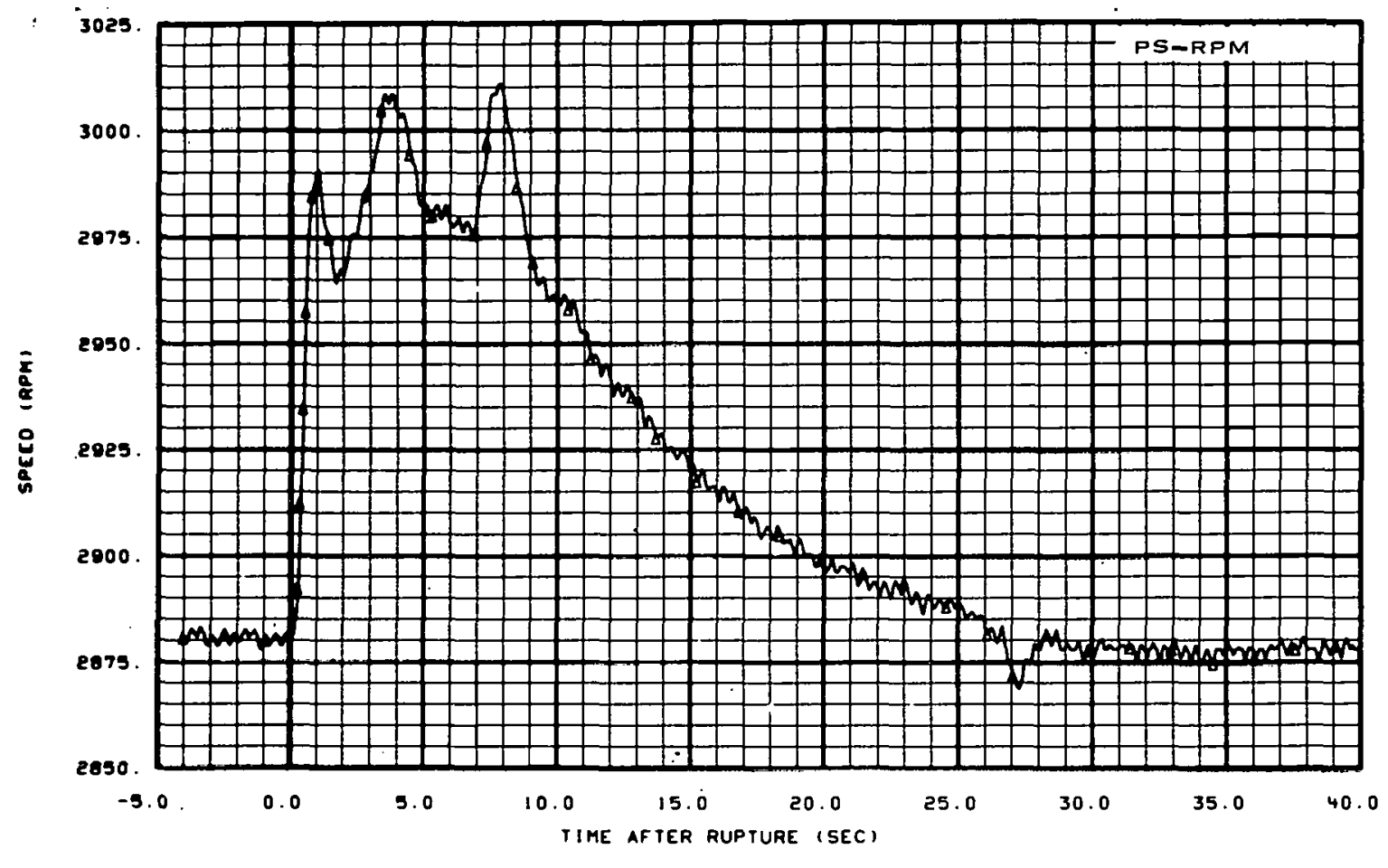

Fig. 155 Pump speed -- Test 1002.

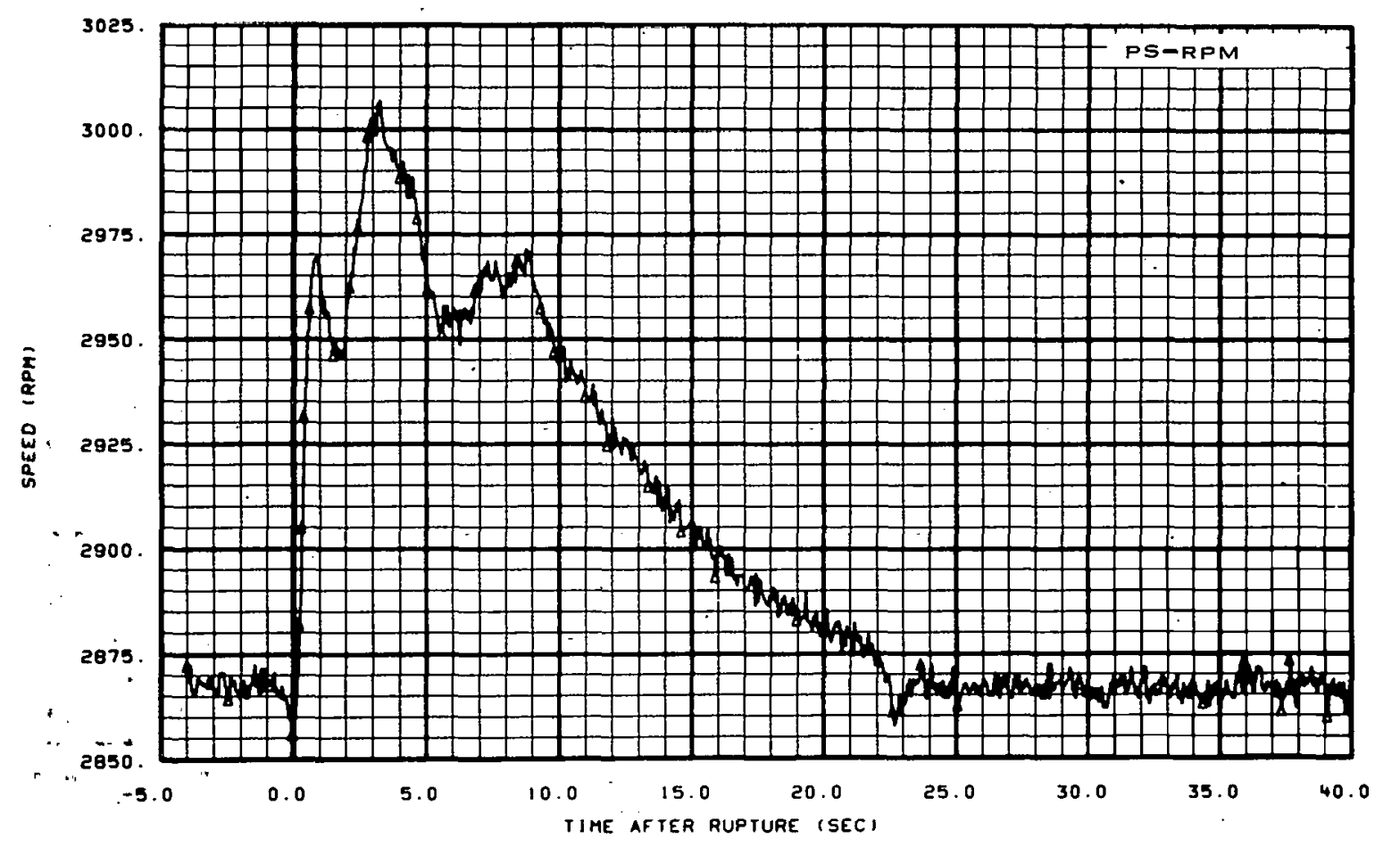

Fig. 156 Pump speed -- Test 1003. 


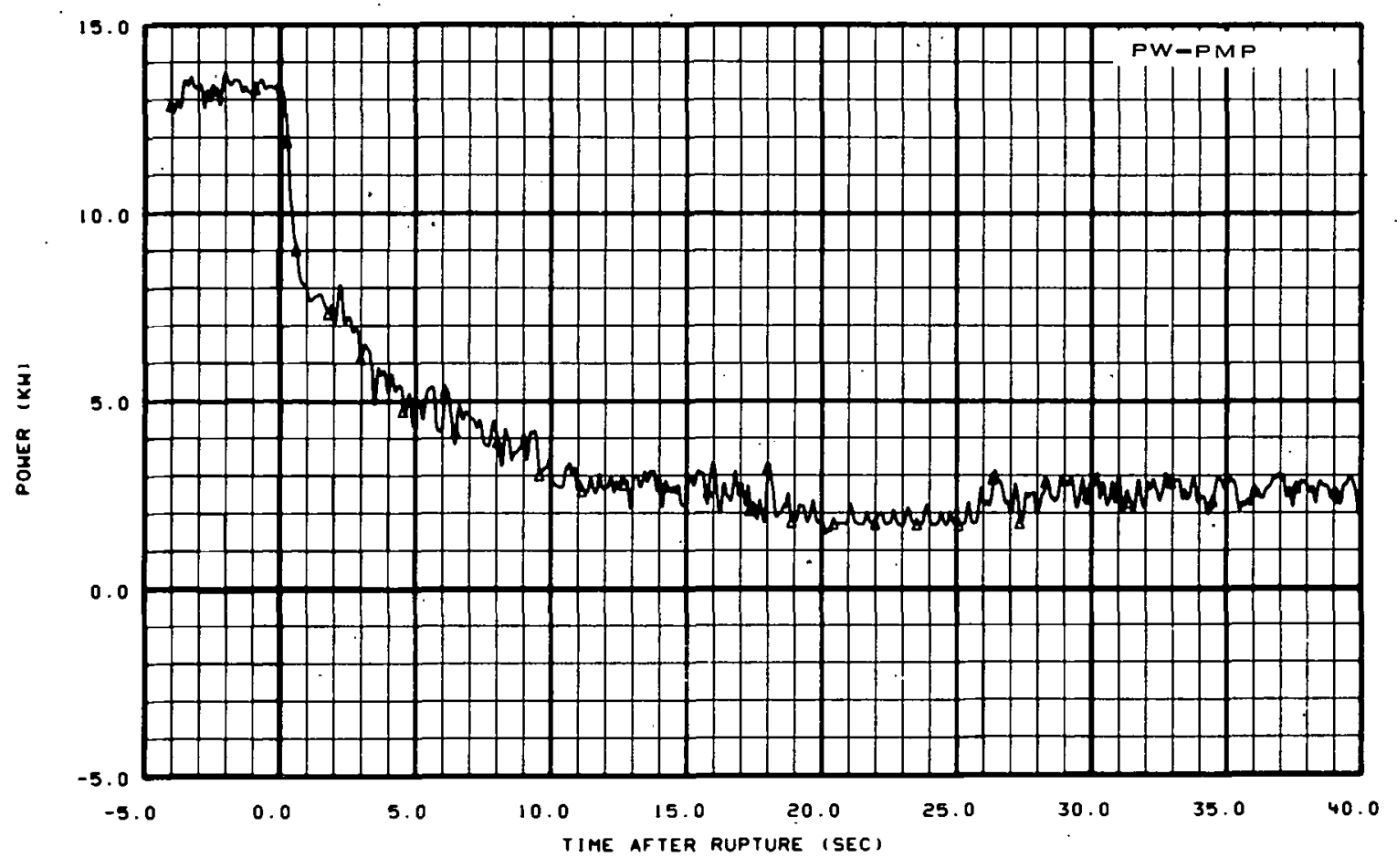

Fig. 157 Pump power -- Test 1001.

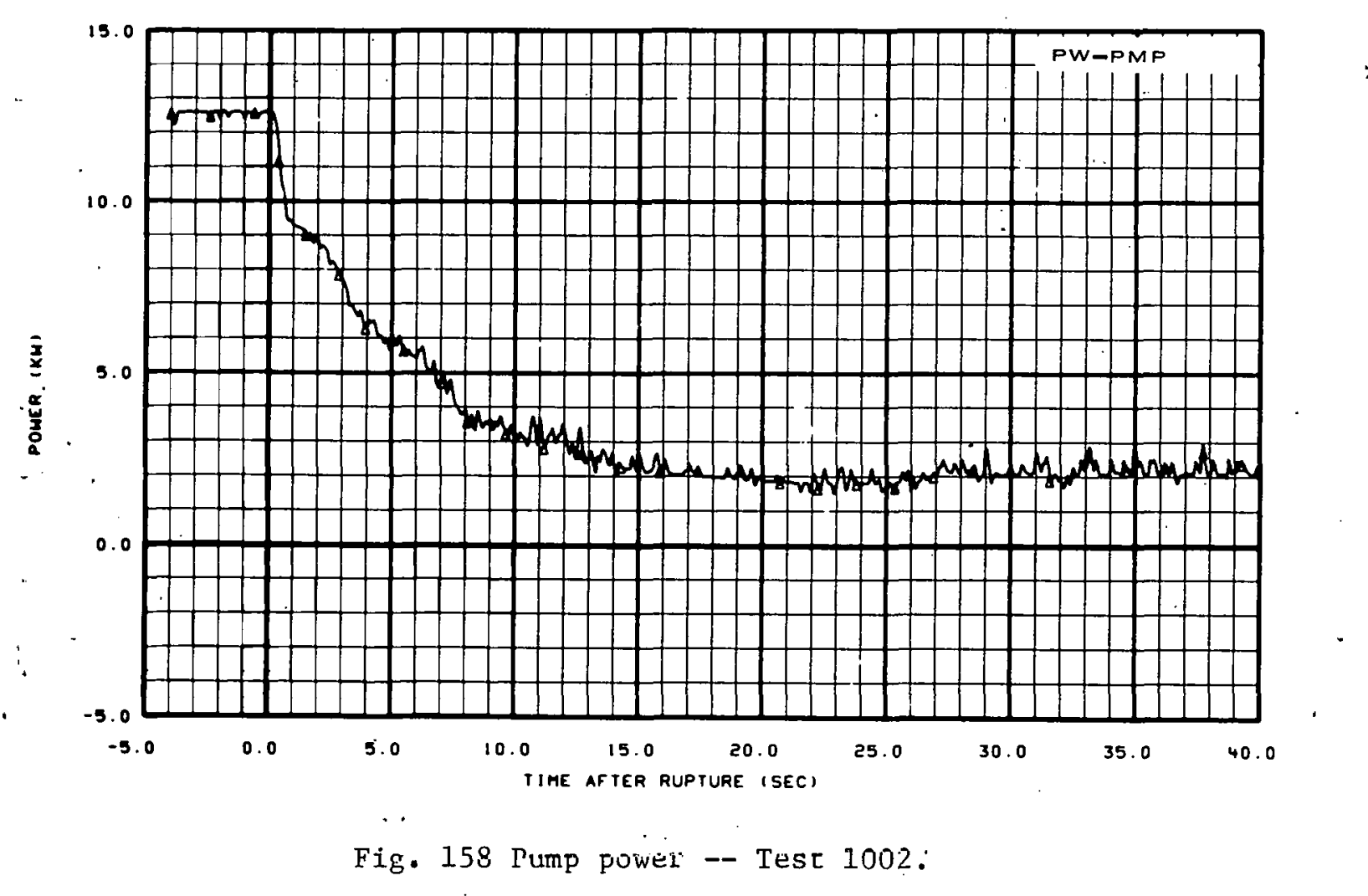




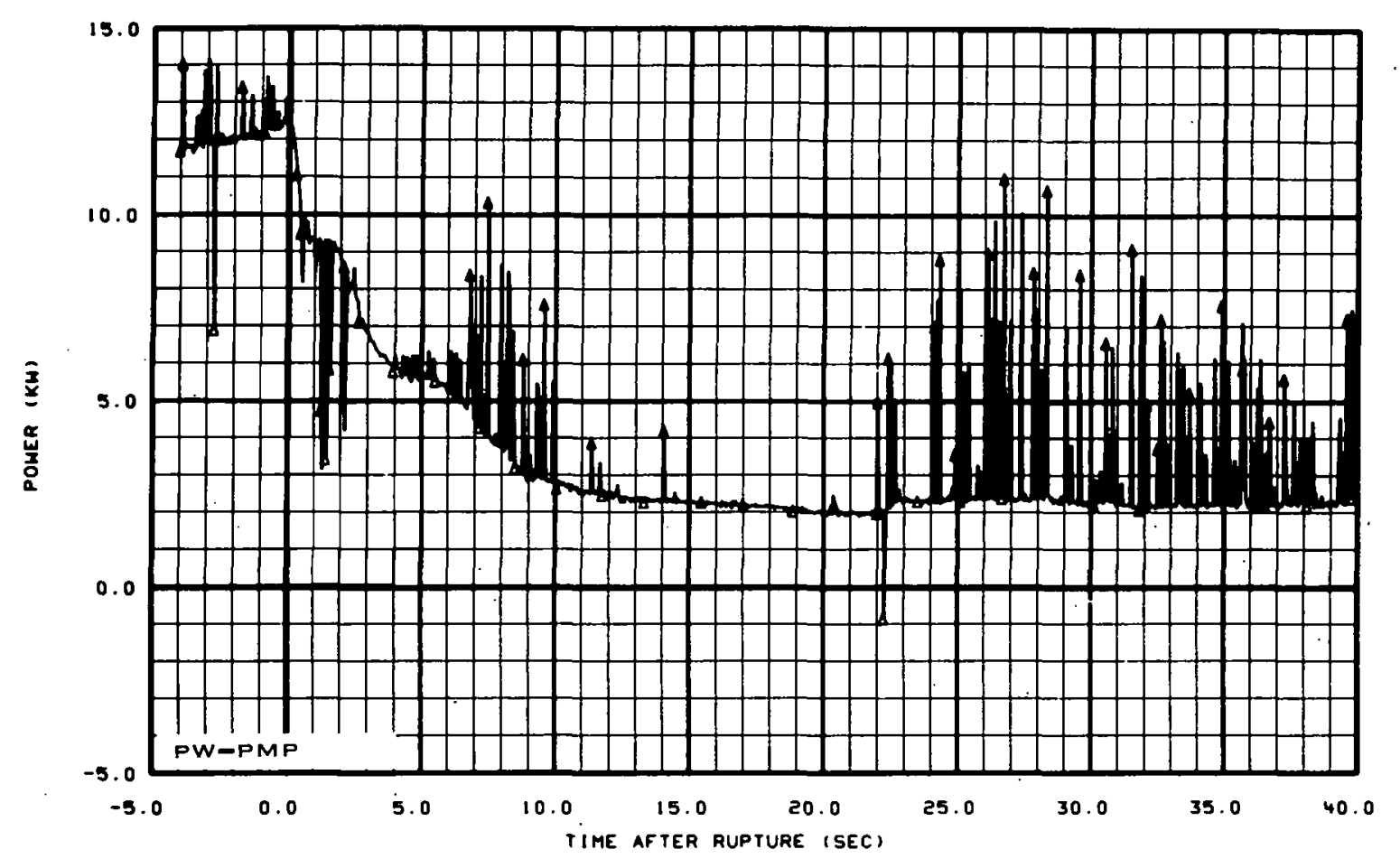

Fig. 159 Pump power -- Test 1003.

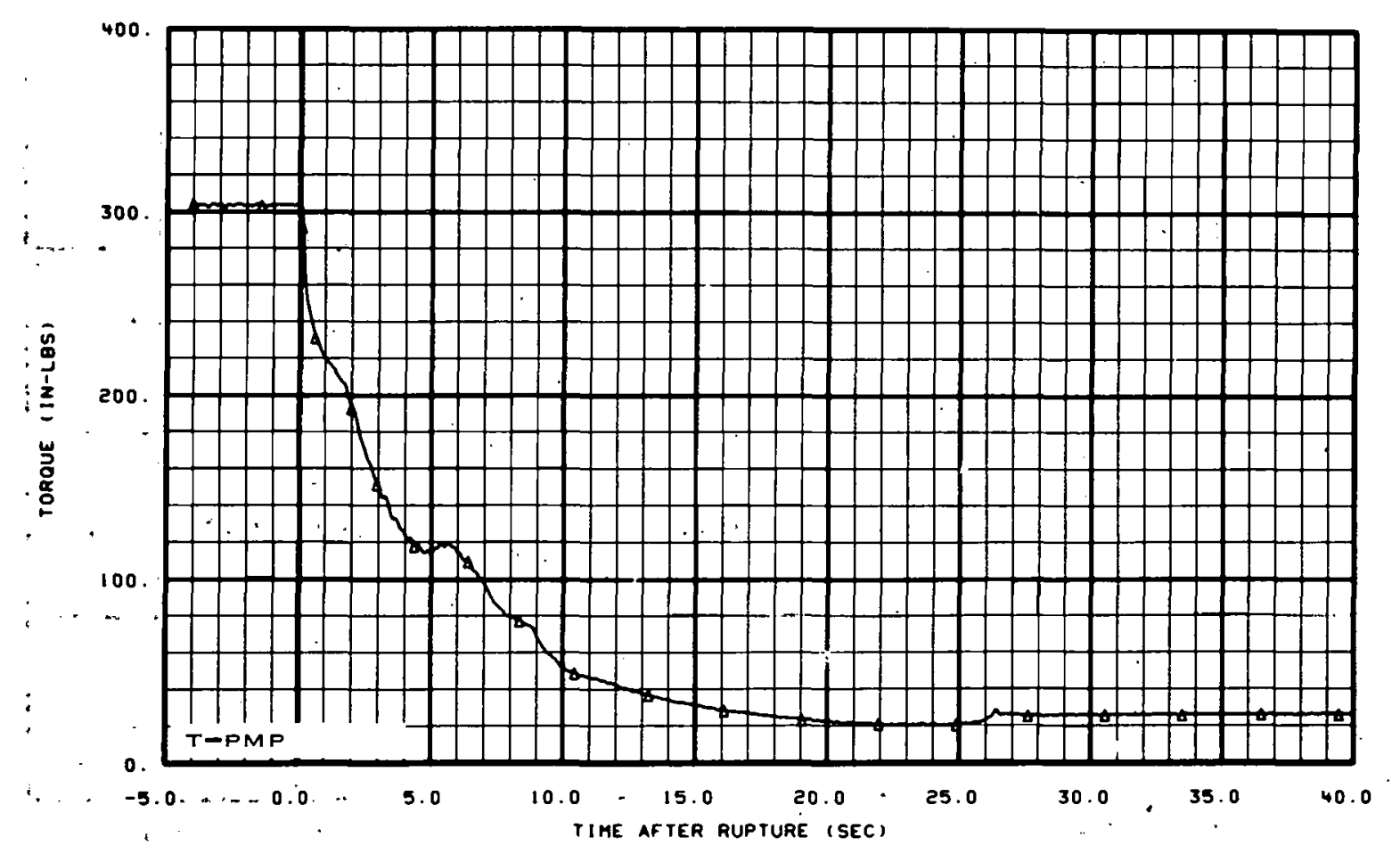

Fig. 160 Pump torque -- Test 1001. 

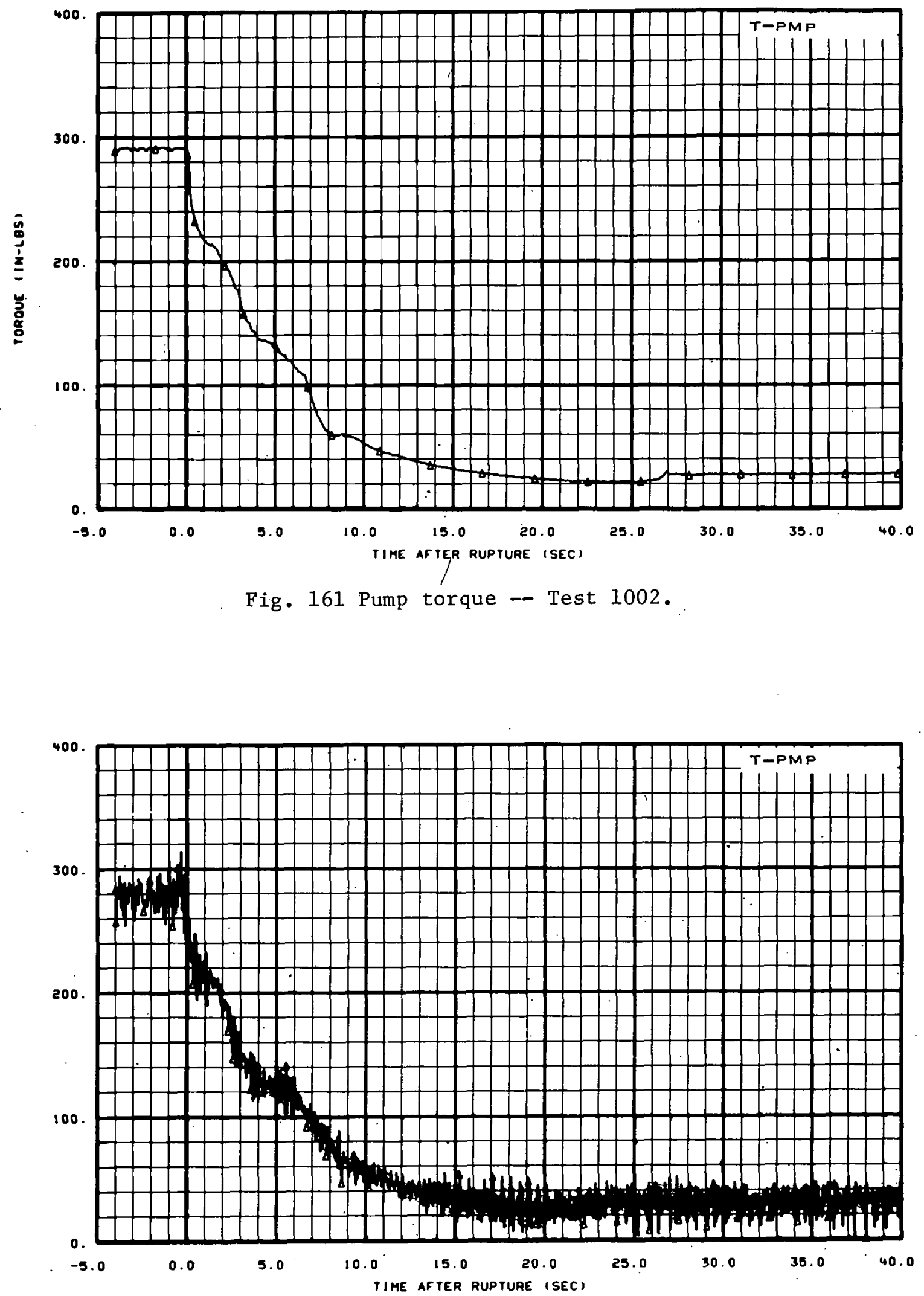

Fig. 162 Pump torque -- Test 1003. 


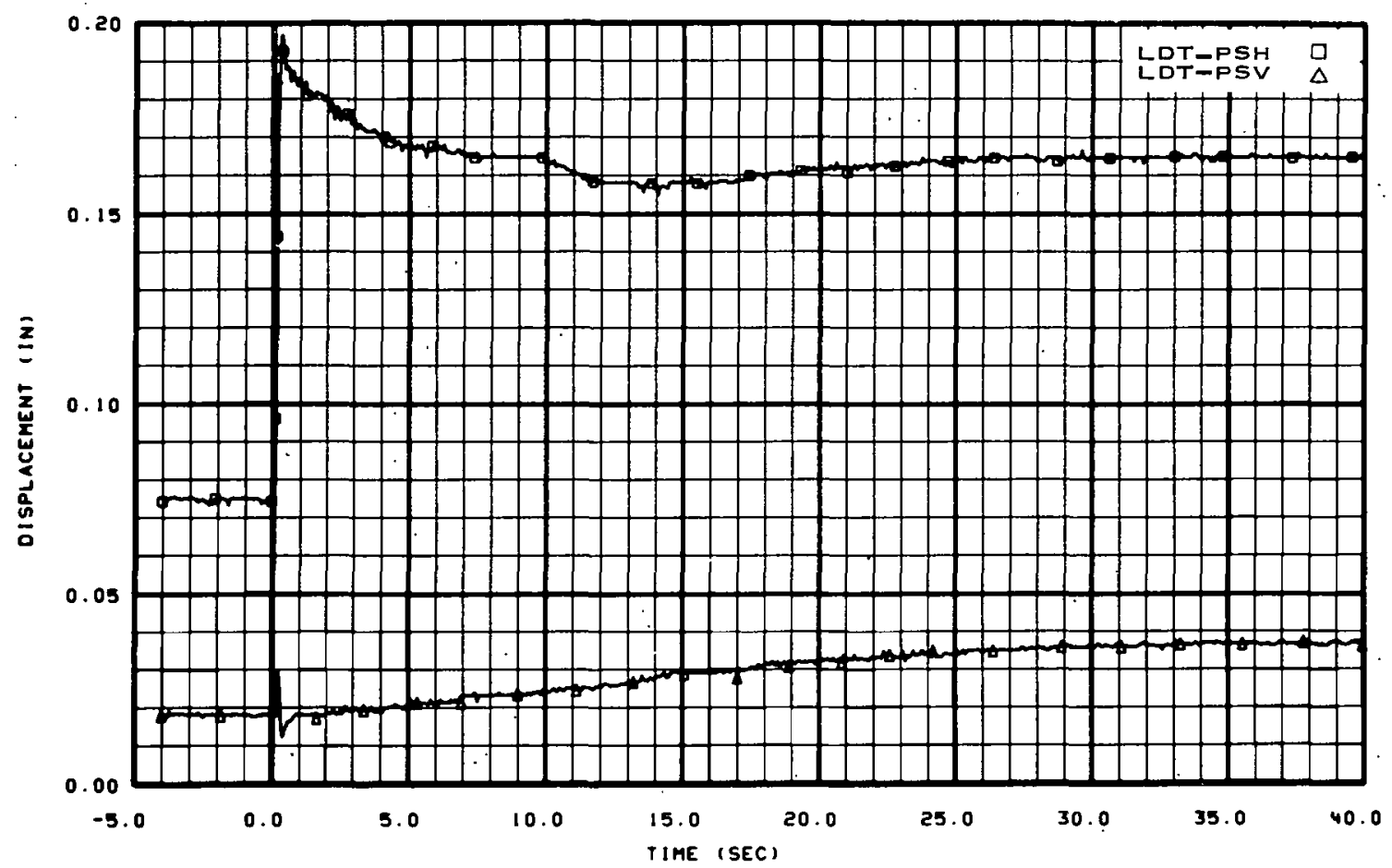

Fig. 163 Displacement of pressure suppression header -- Test 1001.

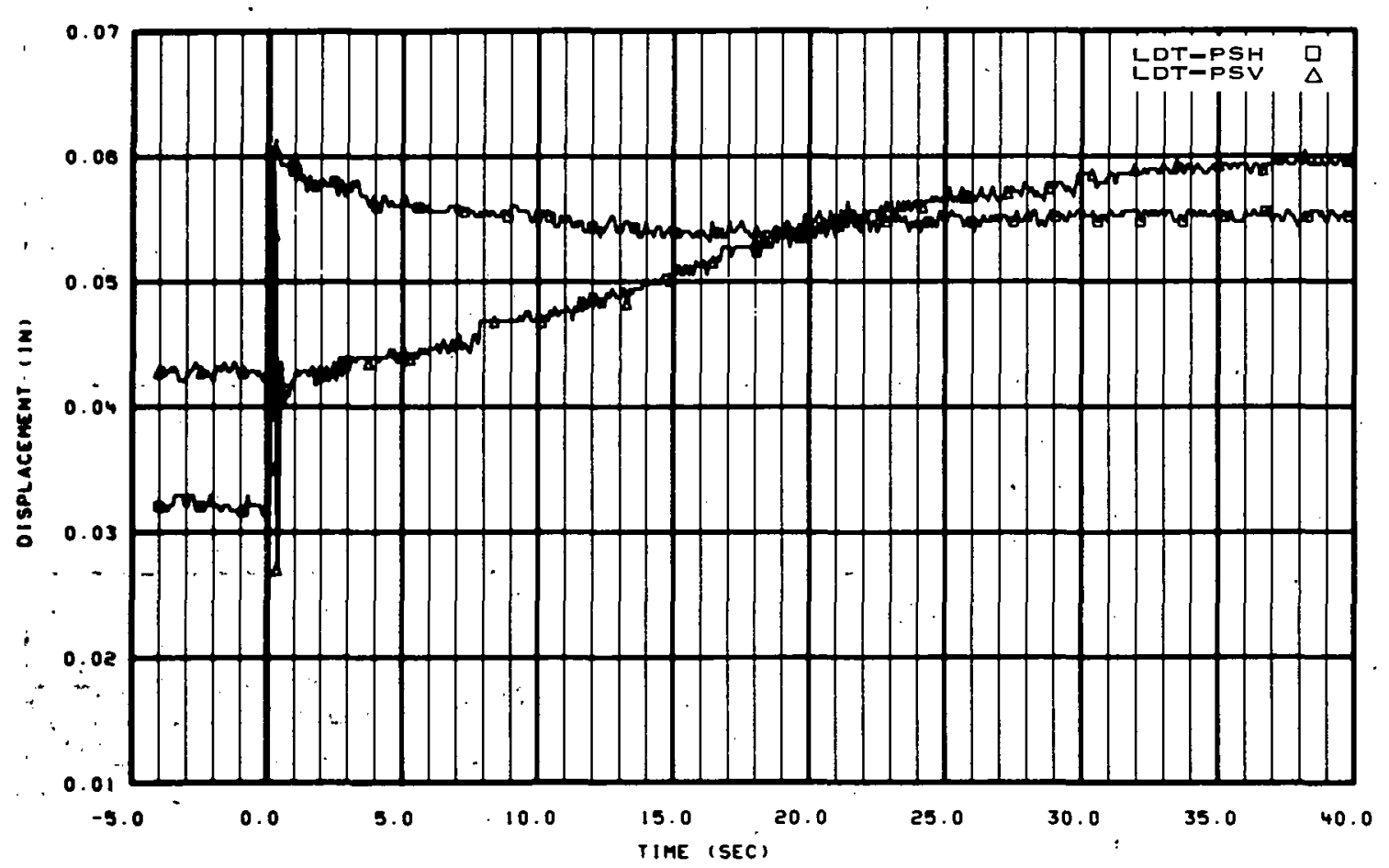

Fig. 164 Displacement of pressure suppression héader -- Test 1002. 


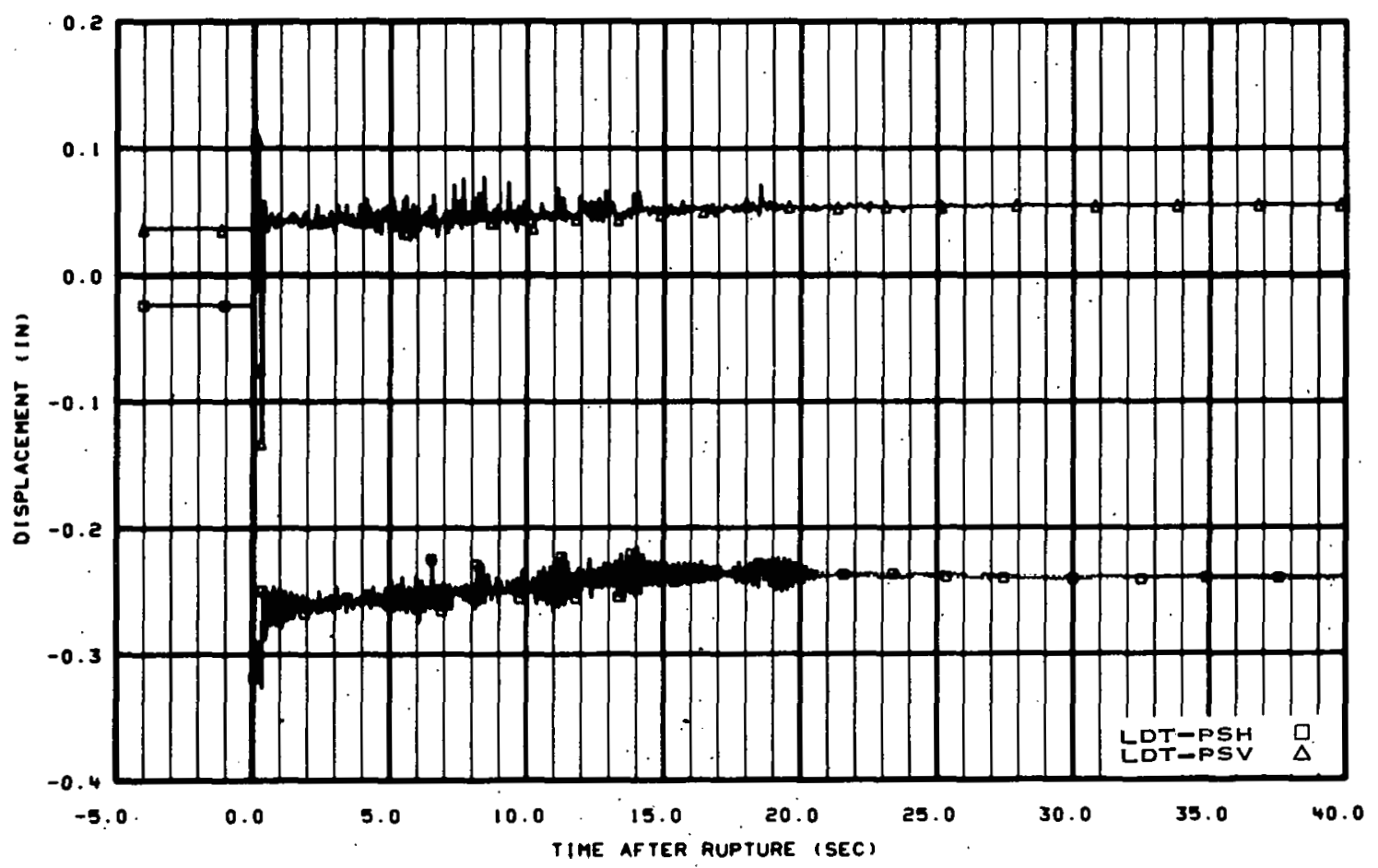

Fig. 165 Displacement of pressure suppression header -- Test 1003. 


\section{REFERENCE}

1. S. A. Naff and P. A. Pinson, 1-1/2-Loop Semiscale Isothermal Test Program-Program and System Description in'Support of Experiment Data. Reports, ANCR-1 143 (February 1974). 
